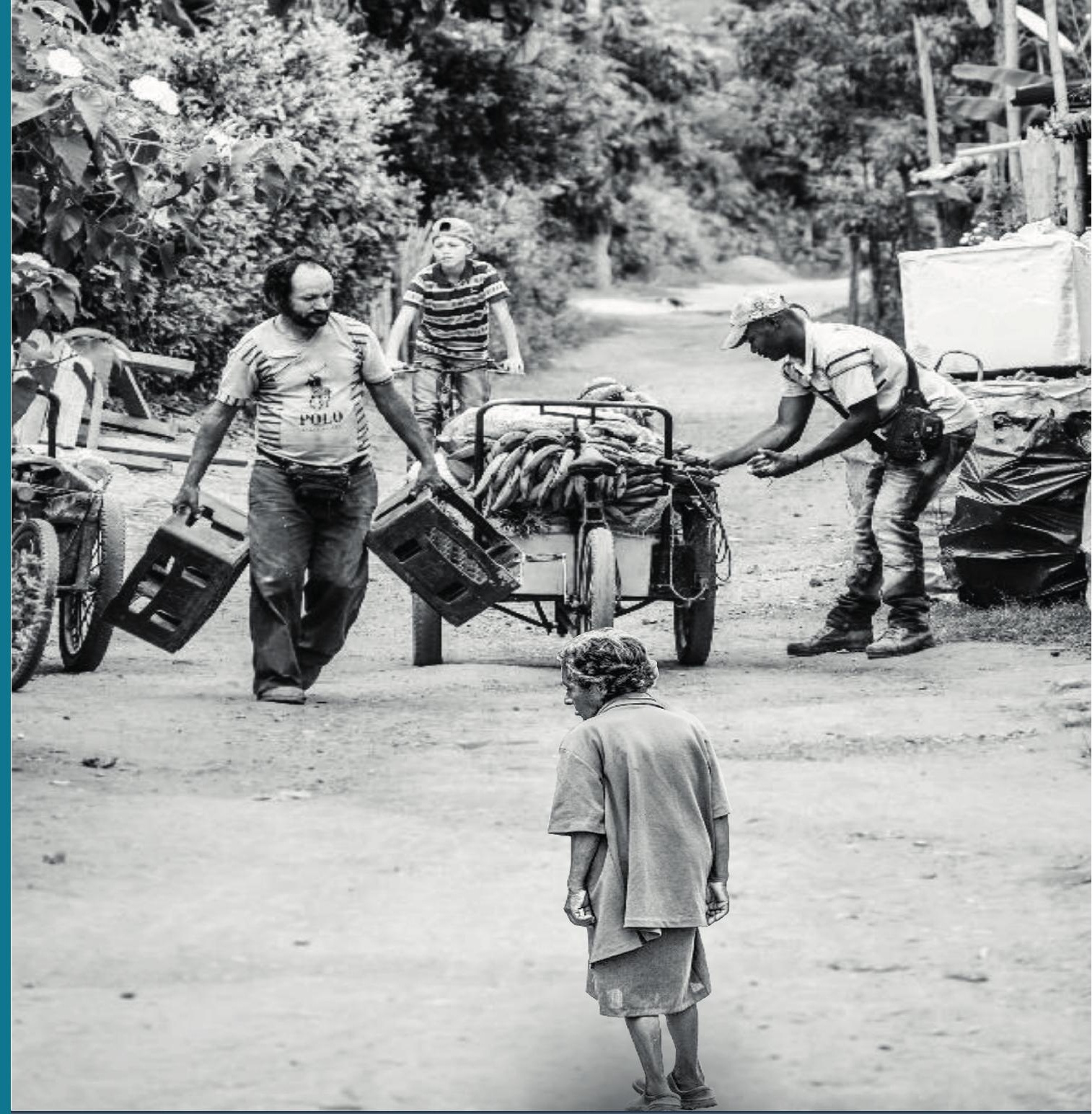

\title{
Morir, resistir y esperar. El ritual en las víctimas por desaparición forzada en Colombia
}

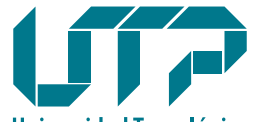

Universidad Tecnológica de Pereira

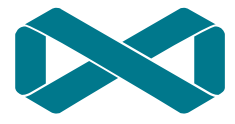

Editorial UTP

Juan Manuel Martínez Herrera 


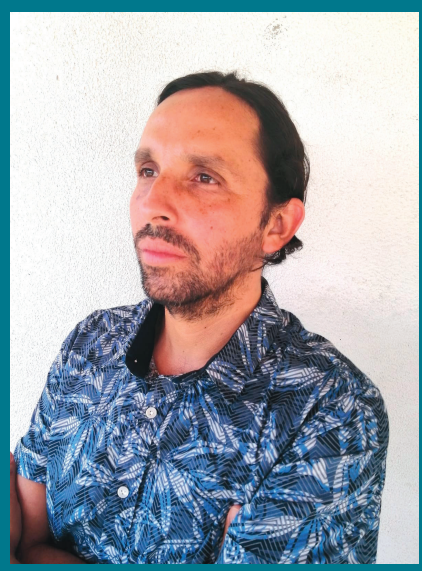

Juan Manuel Martínez Herrera (Pereira, Risaralda, Colombia, 1982).

Doctor en Ciencias Sociales de la Universidad de Buenos Aires.

Magíster en Antropología Social de la Universidad de Antioquia. Profesional en Filosofía y Letras de la Universidad de Caldas.

Profesor transitorio de tiempo completo del Departamento de Humanidades de la Universidad Tecnológica de Pereira.

Coautor de los libros: Magdalenas por el Cauca. Trayectos expresivos de la memoria, (2021) y Mediaciones estéticas y expresividades de la memoria, (2021).

Autor de capítulos de libros y artículos en revistas especializadas.

Integrante del grupo de investigación Arte y Cultura de la Universidad Tecnológica de Pereira.

juanmanuel1@utp.edu.co 


\section{Morir, resistir y esperar. EI ritual en las victimas por desaparición forzada en Colombia}

Juan Manuel Martínez Herrera

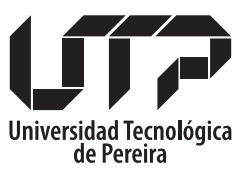

Colección Trabajos de Investigación

Facultad de Bellas Artes y Humanidades

2021 


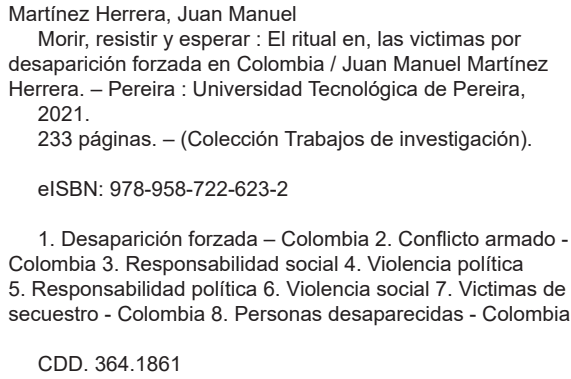

CJuan Manuel Martínez Herrera, 2021

CUniversidad Tecnológica de Pereira

Primera edición

Proyecto de investigación: El papel del ritual en las elaboraciones subjetivas, el caso de miembros de comunidades reasentadas afectadas por la desaparición forzada en Colombia", código (1-15-8) Proyecto de investigación: El papel del ritual en las elaboraciones subjetivas, el caso de miembros de comunidades reasentadas afectadas por la desaparición forzada en Colombia", código (1-15-8)

Universidad Tecnológica de Pereira

Vicerrectoría de Investigaciones, Innovación y Extensión

Editorial Universidad Tecnológica de Pereira

Pereira, Colombia

\section{Coordinador editorial:}

Luis Miguel Vargas Valencia

luismvargas@utp.edu.co

Teléfono 3137381

Edificio 9, Biblioteca Central "Jorge Roa Martínez" Cra. 27 No. 10-02 Los Álamos, Pereira, Colombia

www.utp.edu.co

Montaje y producción:

David Restrepo Suárez

Universidad Tecnológica de Pereira

Pereira 


\section{Agradecimientos}

Hacer posible este proceso dependió de la voluntad y la ayuda de muchas personas. Primero que todo gracias a Melissa; mi cómplice, confidente, compañera, mujer infatigable que supo acompañar este camino. Sé que fue

un transitar espinoso, tanto para mí como para ella, lo padecimos juntos desde perspectivas distintas, ella fue pieza clave para este proyecto no solo como pareja con su amor, sino en especial por su lugar como mujer integra, como par; quiero agradecerle por estos años de aprendizaje recíproco.

Benjamín mi hijo, su existencia es soñar despierto, mi reposo favorito para las angustiosas tardes donde el drama ajeno se hacía mio; de esta forma, gracias a él, también entendí que ese sufrimiento apalabrado por otros no podia ser tan distante. Gracias a su mirada inocente sobre mí, supe que esa tristeza también debía ir algún lado. Verlo cada día a mi lado y saberme feliz por ello, a pesar de lo dificil que es este tema, me ha hecho posible pensar que esta investigación tiene sentido, que la mayor de las eficacias son las que decidimos hacer nuestras sin racionalizarlas demasiado, que aún existen vías en este monstruoso camino de la desaparición y que debemos recorrerlas, por él, por ellos.

A Sebas, mi otro hijo, mi otro hermano, mi gran amigo; en todos estos años hemos aprendido a enseñarnos, nos hemos descubierto entre risas y enojos. Su compañia fue un gran alivio para solventar todo el cansancio y la presión de este trabajo. Mi mamá, la cual hizo posible que me encuentre sentado, en este preciso instante, escribiéndole a ella a pesar de su ausencia, agradeciéndole por regalarme la pasión y la disciplina. La base de este trabajo el fruto de su esfuerzo.

A mi papá que me ha enseñado a creer a pesar de las adversidades, a tener esperanza y a perdonar. Sus convicciones y entrega dejaron una huella indisoluble en mis pasos. 
A mis tios/as, hermanos/as y sobrinos/as, a todos y cada uno de los miembros de «La Comarca», los cuales han sido la red que me ha soportado como persona, como familia y como sujeto; sujetado a ellos de muchas formas. A mi familia extensa que, sin saberlo, siempre hizo parte de este proceso.

A mis directoras de tesis, Amelia y Rubiela, las cuales pusieron más que su rigor académico. Ellas también fueron voz de aliento; me hicieron creer en mí y en cada paso que daba en este proyecto.

A Jhon Wi, su ayuda y disposición tienen mucho que contar de esta travesía.

Por último y no por ello menos importante, sino de manera más especial, agradezco a todas las personas que con sus testimonios me abrieron un dolor albergado por tantos años, aquel atravesado por tantas lágrimas e historias llenas de sufrimiento, las cuales, tristemente, no dejan de escribirse. Ellos y ellas aún creen en el otro; por eso le dan palabras a sus recuerdos y quieren dejar evidencia, registro y, ante todo, reclamar justicia en el nombre de sus seres queridos y por ellos mismos, pues saben que se han ganado el derecho de sentirse orgullosos por enfrentar con valentía las adversidades, las cuales van más allá de una permanente ausencia de alguien que nunca dejarán morir realmente.

En el fondo también les agradezco porque me ayudaron a entender que todos tenemos desaparecidos en nuestras vidas y que todos desaparecemos. Lo importante es preguntarnos, ¿qué hacemos por ellos? ¿Qué hacemos por nosotros? 


\section{CONTENIDO}

Presentación...................................................................................................................

Estructura del texto .....................................................................................11

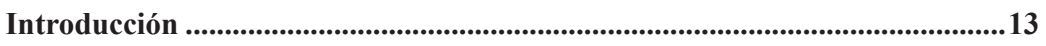

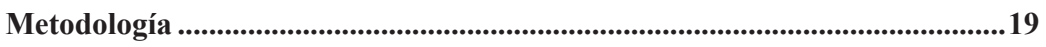

El hallazgo metodológico del testimonio......................................................19

La concreción metodológica...........................................................................25

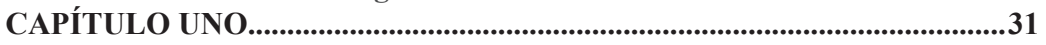

Contexto histórico de la tragedia de vida a la tragedia cultural......................32

1.1. Desapariciones forzadas, ciudadanos intangibles entre la guerra y el progreso ................................................................................................................................33

1.2. Un marco legal ..............................................................................................40

1.3. América Latina ..............................................................................................4 43

1.4. EI caso colombiano ........................................................................................46

1.5. Del primer caso «oficial» hacia una historia sin fin ................................53

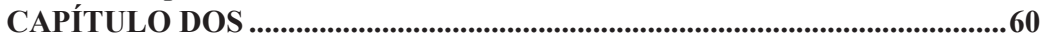

Revisión de contexto, una mirada desviada......................................................61

2.1. La desaparición forzada, un camino entre líneas construidas y recorridos por andarse ........................................................................................62

2.2. Subjetividad, rituales y duelos......................................................................72

2.3. Corolario, el ritual de la verdad .................................................................86

CAPÍTULO TRES ...................................................................................93

Rituales y cotidianidad, el deseo de la vida y el anhelo a la muerte .................94

3.1. Rituales, funciones y representaciones.....................................................96

3.2. La ritualidad en la desaparición forzada ..............................................104

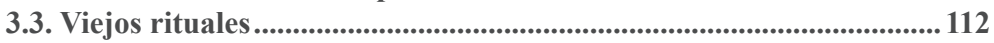

3.4. Nuevos rituales ................................................................................................ 120

3.5. El ritual del recuerdo.......................................................................................125

3.6. Gracias a la muerte...............................................................................130

CAPÍTULO CUATRO ..............................................................................134

EI testimonio y la memoria como puente entre la pérdida y los rituales. EI caso Trujillo ...................................................................................................................135

4.1. La memoria y sus pasados ${ }^{3}$................................................................136

4.2. Responsabilidad política .........................................................................149

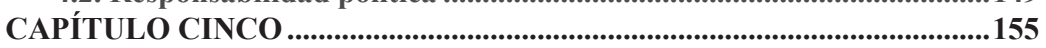

Nociones de la biopolítica de Foucault, rasgos coincidentes en la comprensión de una tragedia .................................................................................................................156

5.1. Un primer tránsito........................................................................................158

5.2. Acción, omisión, intención................................................................169

5.3. Biopolítica, el resultado de comunidades históricas más allá de su aparición como víctimas............................................................................................170

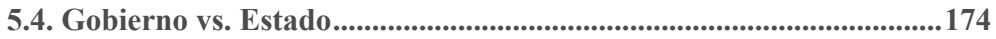

5.5. Rasgos de la biopolítica de Estado, estrategias de fragmentación ...181

5.6. Trujillo y los retazos del caso en un rompecabezas nacional.............186 


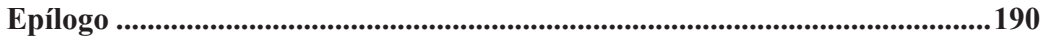

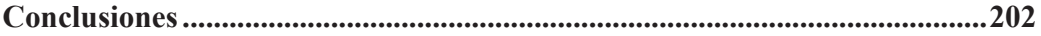

Post scriptum. Diarios de campo en tensión ..........................................................218

Referencias.........................................................................................................................223 


\section{Presentación}

Las posibilidades de abordar una investigación sobre la desaparición forzada desde las ciencias sociales implican pensar en los medios reales de interacción, y en los alcances y los compromisos con los cuales se trabaja. Los campos de interés de este proyecto investigativo, el cual se realizó entre el 2013 y el 2016, oscilaron, por un lado, en las prácticas rituales comunitarias y/o familiares y, por otro, en las elaboraciones subjetivas o los trámites ante la pérdida; en el caso de miembros de comunidades afectadas por la desaparición forzada.

Se desarrollaron los puntos que articularon, de manera relevante, las prácticas rituales y las elaboraciones subjetivas de estas comunidades. En este proceso se encontraron algunos significantes que se vinculan entre la construcción psíquica del sujeto y sus comportamientos ritualizados en la vida cotidiana, lo cual permitió entender el papel de algunas prácticas sociales en el tejido de la población afectada por la desaparición forzada.

Los rituales más estructurados o complejos y los más sencillos o cotidianos narran parte de esa historia que empezó a marcar una interpretación por parte de ellos, después de que alguien desapareció. La comunidad se vuelve un cuerpo social que se mueve entre sus propias tensiones; resignifica sus dinámicas, su territorio, sus amigos, sus vecinos, sus otros; su cotidianidad se condiciona entre el sujeto y sus trámites, y llega, en algunos casos, a la elaboración del duelo producto de la pérdida de sus seres queridos en el marco del conflicto armado. Finalmente, las prácticas de las víctimas materializan la cohesión o fragmentación social de ellos ante un colectivo, su forma de verse y reconocerse ante este.

Los actores con quienes se llevó a cabo este estudio tienen dos rasgos diferenciadores, primero se incluyeron miembros de comunidades que nunca salieron de su territorio después de los episodios de violencia y, segundo, se consideraron algunos integrantes de la población reasentada, los cuales se desplazaron en un momento 
determinado. En estos últimos, la emergencia de aspectos rituales ha sido producto de hibridaciones como consecuencia del contacto con la comunidad receptora, la cual, en muchos casos, tiene múltiples orígenes.

Esta característica dio cuenta de unas prácticas matizadas por diferentes factores, los cuales pueden ayudar o no a la elaboración del duelo. En ciertos momentos se puede resignificar el lugar ante la pérdida al reterritorializar su nuevo nicho social; en otros simplemente el pasado está tan agujereado que no se permite establecer superficies para proyectos hacia el futuro, mediano o largo plazo. En el caso puntual de las comunidades reasentadas, estas construyen una nueva vida a partir de la territorialización de un espacio que no les pertenecía, el cual apropian como suyo desde sus medios de supervivencia hasta sus rituales de cohesión, coacción o distanciamiento al interior del nuevo escenario.

El grupo de interés para la investigación lo conformaron miembros de comunidades afectadas por la desaparición forzada y no solo familiares. Tal distinción entre parientes sanguíneos de los desaparecidos y actores que no tienen un vínculo filial con estos es la que, en diversos lugares como Trujillo en Colombia ${ }^{1}$, ha generado una polarización entre ambos grupos poblacionales donde identificar el rol del familiar es indispensable.

No obstante, el mensaje violento, cifrado en el acto de desaparecer, es dirigido a toda una población sin diferenciaciones, ya que es toda la comunidad la que lee y asume un lugar ante lo sucedido y a partir del lenguaje transmitido por el victimario.

$1^{1}$

1 La comunidad de Trujillo se encuentra ubicada en el departamento del Valle en Colombia. Esta ha sufrido índices elevados de violencia por torturas, asesinatos y desapariciones. Entre 1986 y 1994 se registraron, por parte de la Fiscalía General de la Nación, 342 víctimas, sin embargo, aún se denuncia, por algunos de miembros de la población, casos de persecución y desapariciones sin registrar hasta entrado el año 2009. Es importante destacar que a la fecha, las pocas personas implicadas como responsables jurídicamente en el proceso han sido excarceladas. Por ello, en la actualidad, no se cuenta con ningún condenado por estos hechos. 
La desaparición implica una víctima física que padece la situación y unas víctimas colaterales que sufren los efectos de la misma. De ahí, uno de los hallazgos relevantes lo representa la dimensión de víctimas - en plural-, encarnado en una misma persona, toda vez que las formas de ser victimizado comprometen a varios actores en espacios y tiempos distintos; pero sobre un mismo sujeto en múltiples circunstancias. De hecho, estas condiciones victimizantes pudieron existir antes del suceso concreto de la desaparición forzada.

En el caso de familiares víctimas, cuando elaboran una pérdida, no quiere decir que hacen un duelo, más bien construyen una red de significantes, la cual les permite anudar de nuevo su realidad y, de esta manera, vincularse de otra forma a la comunidad inmediata.

Este trámite se evidencia en las prácticas individuales y en los rituales colectivos cotidianos, los cuales llevaron a constituir lugares comunes o de interés para el trabajo de campo de la presente investigación.

En este punto ha sido importante detenerse en aquello que se ubica entre estas redes significantes y entre lo que se dice y lo que se asume; ese lugar nebuloso y hasta ambiguo de la espera sin esperanza, el cual es precisamente la hendidura donde se centra el sujeto, su vacío, lo ausente-presente; la paradoja de lo no retornado con el cuerpo físico que se supone muerto, pero se sigue esperando vivo; aquello que de alguna manera mantiene, en una condición particular, a cada sujeto dependiente del caso, su posición ante el colectivo y frente los otros sea como familiar, vecino, amigo, esposo, entre otros.

La especificidad de estos roles con el desaparecido implica una socialización que, en ocasiones, contiene algo de esa partida, lo cual aflora en los rituales que permiten reprimir, olvidar, recordar, conservar, esconder o esperar el regreso de un cuerpo que desaparece; pues este se lleva con él un poco de aquellos que aguardan su retorno. 
En ese sentido, tanto el abordaje del sujeto, como de sus representaciones como individuo por medio del ritual cotidiano o las manifestaciones colectivas más estructuradas de una comunidad, implicaron construir, metodológicamente, una estrategia para develar aquello que se escondía tras el trámite que estas personas hicieron en su vida cotidiana. Se problematizó la relación de la elaboración subjetiva ante la pérdida, frente algunos de los rituales comunitarios o individuales que se desarrollaron al interior de cada caso.

La pregunta-problema da cuenta de ello de esta forma: ¿Cuál es el lugar de los rituales comunitarios o individuales de una población víctima por la desaparición forzada y su relación con las elaboraciones subjetivas y/o los trámites colectivos frente a la pérdida? 


\section{Estructura del texto}

La estructura del texto está compuesta por una introducción, en la cual se realiza una descripción general del tema a desarrollar. Posteriormente se encuentra la metodología, aquella compuesta, inicialmente, por el hallazgo metodológico que permite leer aquello contribuyente a la investigación —en ese campo- desde la perspectiva cualitativa y la concreción metodológica, la cual es una especificidad más puntual de este tipo de procesos investigativos donde se dilucida el diseño de las herramientas, así como las técnicas usadas en el trabajo de campo y en el análisis de la información.

Posteriormente se desarrollan los capítulos. Cada uno de ellos, en su estructura, posee un apartado introductorio, el cual presenta el acápite a desarrollar. En esta medida, se destaca la consistencia entre los diferentes apartados a lo largo de todo el trabajo realizado, pues en la introducción de cada aparte se realiza una pequeña síntesis de aquello trabajado en cada caso hasta llegar a las conclusiones.

A pesar de que la genealogía de un tema como la «desaparición forzada» de personas, en un caso como el colombiano, es un proyecto que tardaría varios años y, quizás, al invertir ese tiempo se lograría tan solo una aproximación al tema - debido a lo difícil de recuperar, conservar y actualizar los datos de una práctica permanente y persistente como esta-, la investigación realizada es una suerte de cartografía o un mapa histórico en donde los capítulos son algunos pocos de los muchos relieves que se destacan en el marco territorial de un tema como el de la violencia.

En ese sentido, se realiza una aproximación a la compresión local de experiencias comunitarias e individuales específicas, tanto en poblaciones pertenecientes a los lugares donde acontecieron o acontecen los hechos, así como en el caso de comunidades reasentadas en cascos urbanos. Todo ello permite una mirada desde lo territorial y desde las derivas propias del desplazamiento del lugar de origen. 
La mirada inicia con un recorrido histórico, global y continental, y termina con el abordaje de casos puntuales soportados en referencias conceptuales que ayudan a entender mejor el fenómeno. De esta forma, se debe entender que las conclusiones no son categóricas y buscan, por un lado, entender mejor la naturaleza del acto y sus impactos en la subjetividad y la comunidad y, por otro, sugieren el papel primario que, un tema como el ritual, puede ofrecer al trámite o a la elaboración de los traumas producidos por un desastre humano de estas proporciones.

Por último, es importante aclarar que, en toda la estructura del texto, existen citas permanentes de la evidencia empírica obtenida en el trabajo de campo. En este sentido, se respeta el deseo de todos aquellos informantes que hicieron posible esta investigación en donde pidieron - expresamente - que solo se hiciera alusión a sus respuestas de una manera general sin la aparición de sus identidades. En la estructura general del texto, la forma de referenciar los relatos de las víctimas se hará sin particularizar nombres; en aquellos casos excepcionales donde se hace por razones propias del contenido, han sido cambiados para cumplir con tal acuerdo. 


\section{Introducción}

Los periplos que trae cualquier investigación requieren, de antemano, una apuesta metodológica, la cual proyecte el alcance de los resultados a partir de lo que se trazó como objetivos y lo que se obtuvo como hallazgos. La consistencia y la coherencia, así como los limitantes y las dificultades producto de los precipitados impredecibles de la metodología, en el trabajo de campo, no permiten responder en todo lo estimado. Sin embargo, el proceso en sí es un enclave fundamental del terreno de indagación, es por eso que la metodología es, en sí misma, una investigación propia.

La articulación dispuesta entre la propuesta inicial (el proyecto de investigación) y este producto (el libro como síntesis final) coinciden, en gran porcentaje, con lo diseñado en el anteproyecto. Este se construyó como análisis que relacionara las elaboraciones subjetivas, los trámites colectivos y la ritualidad. Adicional a ello, se demarcó, a lo largo de este recorrido, con los inconvenientes naturales que estas dinámicas contienen, un corpus epistemológico que atravesara el análisis en todo el texto. 
Sin embargo, se debe tener en cuenta que el texto es limitado en ciertas caracterizaciones, en especial en aquellas cuestiones en donde la cercanía teórica o contextual es casi indisoluble; por ejemplo, situaciones en las que hablar de ciertos temas implican anuencias entre líneas muy próximas e, inclusive, dependientes unas y las otras. Tal es el caso de conceptos como «memoria», «testimonio», «narración», «verdad», «recuerdo», «historia», entre otros. Por tal razón, en el trabajo de campo se encontraron casos donde la voz testimonial puede parapetar la víctima y su lugar con el relato, al ser complejo desplegar o distinguir con claridad todo lo que allí se puede encontrar; un recuerdo, una contención subjetiva a lo vivido, un recurso de supervivencia, entre otros.

El ambiente histórico que ha estructurado campos de violencia política, en un país como Colombia, conlleva a que la cercanía entre fenómenos, los cuales definen o hacen posible el, guarden ciertas precauciones en la lectura, ya que, reasentamiento, desplazamiento, desaparición, reubicación y reterritorialización se constituyen como un recorrido susceptible de ambigüedad por la naturaleza relacional de uno en relación con otro. Esta situación implica ubicar la trama de sentido que lo define en cada momento, contextualizarlo específicamente y realizar algo parecido a lo que los estudios culturales llaman «contextualismo radical», el cual se define como «... ese campo transdisciplinario que busca comprender e intervenir, desde un enfoque contextual, sobre cierto tipo de articulaciones concretas» (Restrepo, 2012, p. 157). De tal forma, esta investigación no está exenta de dicha advertencia, se ubica contextualmente sin pretender relativizar cada campo en el cual se desarrolló, por medio de epifenómenos, pero tampoco al dejar una noción categórica, totalizante o determinista de lo hecho.

Previo al desarrollo introductorio de la investigación, es importante, en ese sentido, aclarar que la cercanía entre la «desaparición forzada de personas» en Colombia y el «desplazamiento forzado» constituye un punto nodal del conflicto armado en el país. Por ello, se debe entender que muchos de estos acontecimientos están anudados, ya que la desaparición conlleva al desplazamiento en casi todos los casos y, adicional a ello, moviliza la reubicación de los desplazados 
en reasentamientos en las ciudades. Esta se encuentra mediada por los efectos de ambos sucesos, pues se padece la angustia de la ausencia del desaparecido y, además, el despojo de su hábitat social, tal como se refleja en el siguiente párrafo.

Los desplazados tenían en sus lugares de procedencia nichos vitales, construidos y cultivados durante años por generaciones e incluso por sistemas hereditarios de sucesiones de tierras. Eran, pues, escenarios estables que si bien no lograban subsumir los sueños de un mejoramiento, conformaban un patrimonio seguro y conocido. La salida de su tierra y el ingreso en nuevos contextos han tenido una consecuencia de facto: el desempleo o, más acertadamente, la carencia de trabajo (Arboleda, 2009, p. 253).

Ambos fenómenos son coexistentes y su campo requiere identificar la presencia permanente de lo uno sobre lo otro, en especial de la desaparición generadora de desplazamiento. Sin embargo, durante el texto, el eje problemático será focalizado al tener en cuenta el primero de estos dramas humanos — sin desestimar el lugar del otro- - y, más aún, las comunidades reasentadas con las que se trabajó y donde se presentan puntos críticos en la adaptación, tal como lo señala Arboleda (2009). A pesar de ello, es importante tener en cuenta la naturaleza contextual sobre la desaparición forzada que movilizó esta investigación.

En ese sentido, la «desaparición forzada» se entiende como una práctica en el marco de un conflicto, en la cual se captura y, en la mayoría de los casos, se tortura a integrantes de una comunidad sean activistas políticos, religiosos, comunitarios, actores de un bando en el contexto de una guerra $\mathrm{o}$, simplemente, población civil. Tal práctica se hizo famosa en medio de la escalada de persecución antisemita de Hitler, en la Segunda Guerra Mundial, y se popularizó como maniobra sistemática en América Latina a partir de las dictaduras de mediados del siglo xx; aunque parte de los antecedentes iniciales de este fenómeno se presentaron a principios de dicho siglo, en el marco de la guerra civil española. 
Para comprender las particularidades sociales de este tipo de actos violentos, es necesario leer las improntas que han distinguido la naturaleza de una escena social tan fuerte y tan traumática como la que se vive en el contex to colombiano. Circunstancia que hace de esta deriva académica una travesía por el dolor, en la cual cada historia constituye un mapa distinto en la cartografía del miedo, tal como sucede en un país tan ultrajado por temas como la desaparición forzada, pues esta se presenta en sitios muy distantes de la geografía nacional.

El diagrama analítico de este trabajo inicia con una descripción metodológica, no solo del diseño y las herramientas usadas, sino de las imposibilidades de las técnicas cualitativas al tratar de entender las diferentes voces de un actor que no se puede encerrar en un solo relato; quizá por eso, en la escritura, se evidencia el deseo de muchos entrevistados por no querer dar su nombre, - ni siquiera uno ficticioque los identifique en su historia, pues en ocasiones hablaron de esas memorias, las cuales se tornaron en una suerte de «desiertos discursivos» llenos de soledades en un mismo cuerpo.

Aquello que cobra significado aquí no es el relato, ni las fechas, ni los nombres del corpus de los actores involucrados en la investigación; es la necesidad de pensar con su dolor y más allá de este, es decir, con todo lo que aún está por decirse, escribirse, investigarse y proponerse en un país tristemente sumergido en una guerra de múltiples tonos, la cual abarca la política, lo económico, lo social y lo cultural.

Después de la precisión metodológica, se aborda el primer capítulo denominado «Contexto histórico de la tragedia de vida a la tragedia cultural». Este presenta la contextualización de un pasado-presente llamado desaparición forzada y analiza la persistencia de tal fenómeno, el cual no solo evidencia la brutalidad de lo vivido, sino la indolencia naturalizada de todos aquellos que hacen parte del territorio colombiano donde existen múltiples responsabilidades compartidas: el Estado y los homicidas que operan en nombre del mismo - con su anuencia o su inoperancia para juzgarlos - las víctimas y, finalmente, los victimarios pasivos que han volcado la mirada «sensible» tan solo al antojo de los medios. 
Posteriormente se trabaja un segundo capítulo intitulado «Revisión de contexto, una mirada desviada». En este se realiza una exploración del tema de la desaparición forzada, en el caso puntual colombiano, y se toman algunos hallazgos del estado del arte, los cuales se problematizan a partir de lo encontrado, de las recurrencias, así como de las distancias en el tipo de investigaciones. Se cotejan algunos de los insumos propios del trabajo de campo realizado. Por último, se hace un análisis con base en el ejercicio trabajado sobre la desaparición forzada y la subjetividad, al obturar la mirada en la elaboración, el duelo y la justicia soportada en la coincidencia y la disidencia de los trabajos de dos autoras como Zorio (2011) y Díaz (2011).

Luego, en el capítulo «Rituales y cotidianidad, el deseo de la vida y el anhelo a la muerte» se aborda el eje central de esta investigación. En este momento, sin poderlo evitar, se tejieron rituales y sus funciones sociales en los diversos trámites colectivos y subjetivos desde prácticas comunitarias tradicionales, hasta las emergencias rituales posteriores al acontecimiento, algunas de estas terminaron en el recuerdo del desaparecido y en el deseo de su existencia, así fuese por medio de su negación física, pues en sus propias palabras decía: «... que aparezca así sea muerto, pero que aparezca» (Virginia, comunicación personal, julio de 2014).

Toda esta cartografía empieza a evidenciarse de forma focal en el capítulo «El testimonio y la memoria como puente entre la pérdida y los rituales. El caso Trujillo». En este se trabaja el testimoniar como deriva más allá de una palabra que narra una historia. Se trabajaron algunos elementos académicos y contextuales de este concepto, se hizo hincapié en una masacre como la de Trujillo — en el Valle del Caucay se anudó el proceso a la pregunta por la responsabilidad política y sus implicaciones desde múltiples miradas.

El último capítulo se denomina: «Nociones de la biopolítica de Foucault, rasgos coincidentes en la comprensión de una tragedia». Este busca establecer las relaciones existentes entre la teoría de la biopolítica de Foucault y el caso colombiano. Por ello, se parte por aclarar que tal relación no es directa ni explícita, en relación con la tesis del autor, pero 
si tiene bastantes puntos de coincidencia cuando se refiere al control político del cuerpo y su intención de sometimiento de la interacción social por medio del dispositivo controlador que sobre él se ejerce.

Así, desde el capítulo inicial que procura establecer las condiciones de contexto incidentes en la genealogía de la desaparición forzada en Colombia, se busca establecer un terreno inicial para que los apartados siguientes desarrollen las formas en las cuales se sedimenta este proceso y se transita desde la práctica colectiva, hasta la elaboración subjetiva y la representación o posible trámite de del mismo en las escenas rituales.

De esta forma, los estudios de caso y su contrastación conceptual permiten entender en los capítulos finales que la magnitud de esta tragedia no es plenamente comparable ni teorizable desde la teoría social, ya que las particularidades del tema en el contexto colombiano son de una magnitud tal que se escapan a las categorías usadas en otros lugares, en especial en el tema de la latencia del conflicto, la repetición y la revictimización. Así el abordaje realizado y la comprensión focal ayuda a entender la naturaleza de dicho fenómeno en escenarios locales donde pueden existir o no posibles coincidencias con otras latitudes.

Finalmente se trabajaronlas «Conclusiones». Allí se esbozó un camino que permite pensar en otros procesos sociales de elaboración realizados por las víctimas sobre desaparición forzada, los cuales son diferentes a los habituales. Se hace manifiesta la necesidad de profundizar nociones como la de víctima y relato desde estructuras teórico-metodológicas más amplias y comprensivas, que no instrumentalicen o limiten la voz de un actor en un solo sentido. Esto posibilita, por un lado, el reconocimiento de los pliegues disposicionales y de las temporales del momento en el cual se narra una historia por parte de una subjetividad, la cual está lejos de ser estática. Por otro lado, cobra especial relevancia la potencialización del ritual, sus derivas, sus alcances, sus limitaciones y sus posibilidades en las prácticas de elaboración y cohesión de un tejido social tan fragmentado históricamente como el nuestro. 


\section{Metodología}

\section{El hallazgo metodológico del testimonio}

Las ciencias sociales han incursionado en los últimos años en un número extenso de conceptualizaciones sobre metodologías, diseños, técnicas y herramientas que buscan, desde lo cualitativo, la consistencia del trabajo empírico o trabajo de campo por medio de unas categorías de análisis. Todo ello en procura de otorgarle rigor científico a la denominada «investigación cualitativa».

En ese sentido, el testimonio se convierte en objeto primario del dato, tanto por lo que transmite como por la credibilidad de lo que se sustenta. En la investigación realizada, dicho testimonio se presenta en una doble condición, la víctima y el testigo primario de un crimen, es decir, un sujeto habitado por múltiples relatos.

Esta característica diferencial no es desarrollada con mucha frecuencia en el caso de la metodología de investigación cualitativa. Al contrario, otros conceptos que han tenido un impacto en las metodologías contemporáneas de manera muy fuerte, como es el caso de la memoria y la historia, ocupan gran parte de la literatura en este tipo de áreas en el último siglo, tal como se referenciará más adelante.

Autores como John Beverley (1987) problematizan las formas de testimoniar y las implicaciones de este concepto, gracias a que las entrevistas a profundidad permiten codificar la experiencia de un actor frente a un tema o problemática específica. No obstante, como en la investigación realizada no es fácil discernir en los roles que un entrevistado cumple bajo un mismo relato y en un mismo territorio, lo cual afectaría lo que el mismo Beverley (1987) denomina bear truthful witness, veracidad o confiabilidad del testimoniar, al seguir al autor inglés se entiende lo siguiente: 
Un narrador que es a la vez el protagonista (o el testigo) de su propio relato. Su unidad narrativa suele ser una "vida" o una vivencia particularmente significativa (situación laboral, militancia política, encarcelamiento, etc. [sic]). La situación del narrador en el testimonio siempre involucra cierta urgencia o necesidad de comunicación que surge de una experiencia vivencial de represión, pobreza, explotación, marginalización, crimen, lucha (Beverley, 1987, p. 9).

Dar o ir por un testimonio implica movimientos subjetivos muy amplios, pero, lo más problemático, en términos metodológicos, no es esto ni lo que Beverley (1987) señalaba como el «auge del testimonio», sino, más bien, entender un testimoniante que narra una realidad desde tantos ángulos. Se piensa en un actor a la hora de investigar y se va por su huella, su voz y su grafo en el mundo. Sin embargo, no se dimensiona un personaje inaprehensible y, quizás, en algún aspecto intraducible al relato de otros que quieren verlo como un ser unidimensional y con una historia de vida concreta.

El testimonio es un lugar de disposición en un campo específico. Este permite entender la dualidad superada de lo objetivo (del relato) y lo subjetivo (del testimonio) expuesta por Bourdieu (1997), pues tal disposición implica o «... designa una manera de ser, una propensión o una inclinación» (p. 95) y el sujeto es habitáculo multiaxial evaluado por el medio o el interlocutor que da sentido y significado a aquello que escucha, frente aquello que el actor necesita decir en distintos escenarios.

El conflicto colombiano no puede verse reducido a la relación víctima victimario y, mucho menos, su abordaje metodológico, pues esto implicaría la homogenización del relato, la castración de una evidencia empírica dirigida exclusivamente a una taxonomía de actores definidos.

El riesgo de esta situación conllevaría a consecuencias como señalar la justicia desde la generalidad, es decir, las múltiples responsabilidades serían cooptadas o reducidas a quien ejerce o quien 
padece, sin ubicar, todos los niveles de esta característica, tales como la acción, la complicidad y la omisión donde se debe dar lugar al papel de todos aquellos que tienen que ver con esa idea compleja llamada Estado.

La naturaleza misma de la violencia en el país y su lógica disposicional puede cambiar de espacio así como de temporalidad y, por ende, de lugar subjetivo ante una crisis que está lejos de terminar de vivirse. Los relatos de la Shoah situaron a las personas en la discusión ante el horror de la condición humana y, a partir de ellos, se multiplicó la noción de testigo, memoria, recuerdo y testimonio; en especial desde académicos, analistas y sobrevivientes, al colmar el aturdimiento con las experiencias de estos últimos como es el caso de Primo Levy, Paul Celan y Jean Améry. Particularmente al pensar el efecto mortal del recuerdo y las implicaciones de revisarlo, apalabrarlo y socializarlo insistentemente, tal como lo señala François Forges (2006) «En realidad las víctimas no necesitan de nadie para recordar. Los recuerdos inolvidables están agazapados en un rincón de su memoria» (p. 164), la pregunta es saber ¿cuándo evocarlos?, ¿cuándo asaltan la consciencia? y ¿cómo se sobrevive a ellos?

En todos estos casos el patrón común es claro: reponerse o no de la tragedia, darle urgencia al relato y visibilizar lo sucedido; $y$, desde el escenario metodológico, investigar con cuidado la narración del «otro» que será usada como instrumento de análisis, volver dato la palabra y conservar la esencia de lo dicho por el testimoniante. Siguiendo a Forges (2006):

El testimonio debe ser de una verdad absoluta. A pesar de su urgencia, a pesar de su emoción, debe ser hecho con rigor científico. Como los químicos que describen escrupulosamente la naturaleza de las cosas, como un informe de policía hecho ante un tribunal. El testigo se esfuerza por describir lo que vio, ni más ni menos. Todos los libros de Primo Levy están atravesados por esta ansiedad. (p. 201) 
La particularidad metodológica de esta investigación es precisamente que el horror no cesa, es insistente y, además, amenazante. El relato no se puede ver desde la perspectiva del recuerdo y la idea de víctima disiente profundamente de la experiencia de los sobrevivientes de los campos de concentración.

En este caso no puede existir una verdad absoluta en medio de la incertidumbre y, en consecuencia, no se puede contener la voz del testigo en un relato. Todo ello constituye una encrucijada metodológica que implica atravesar el análisis desde el lugar disposicional y desde las múltiples voces de una misma voz en la toma de posición al contar. Sin embargo, se parte por entender las víctimas como aquellas que enfrentan situaciones victimizantes concretas, testigos de primer orden que cuentan la cronología de una tragedia y sus crisis episódicas, dando forma a un relato. En palabras de Beverley (1987):

La autoridad del testimonio deriva del hecho de que el narrador es alguien que ha presenciado o experimentado en propia persona -o indirectamente a través de la experiencia de amigos, familiares, vecinos, etc [sic] los acontecimientos que narra. Lo que da forma y sentido a esos acontecimientos - es decir, lo que los hace historia - es la relación entre la secuencia temporal de los acontecimientos y la secuencia de la vida del narrador o narradores, plasmada en la estructura verbal del texto testimonial (p. 10).

Esta idea inicial de Beverley (1987) da una caracterización genérica, pero termina siendo insuficiente para el caso abordado, pues las víctimas en este contexto tienen diversas improntas y dependen del espacio y del tiempo habitado, lo que implica una variación en su análisis sobre lo vivido.

Algunas de estas variaciones de la condición de víctima identificadas son: 
- Víctima por la ausencia del otro; el desaparecido. Es víctima, en este sentido, por quedar desprovista de ayuda, sustento o acompañamiento económico o emocional por parte de su ser querido.

- Víctima de un acontecimiento traumático presenciado que le dejó una impronta en la subjetividad. Todo ello a partir de una o, en algunos casos, varias experiencias de suma violencia.

- Víctima de un perpetrador y del mensaje de intimidación que enunció sobre el cuerpo social, lo cual se debe asumir en esa nueva lógica de poder que quiere instaurar.

- Víctima de un Estado incapaz de proteger de una situación de riesgo, cuando el actor social y la población han sido víctimas por el padecimiento de un abandono histórico $\mathrm{y}$, luego, por otra circunstancia como la no garantía de seguridad y protección ante amenazas externas, las cuales, en muchos momentos visibles y predecibles, terminan en desapariciones, masacres o desplazamientos masivos. El Estado, a través de actores que lo representan, fungen como perpetradores directos o con la aquiescencia suya para la intervención de grupos paramilitares.

- Víctima de la no reparación integral posterior al hecho.

- Víctima de una sociedad que ve en el reasentado a alguien objeto de lástima cuando mencionan, por televisión, las víctimas de la violencia en el país $\mathrm{y}$, después, como objeto de peligro cuando los reubican cerca a sus casas como vecinos. 
- Víctima de un cambio cultural, el cual implica reconstruir, desde la cotidianidad, los hábitos más sencillos hasta los más complejos, de significación de entorno y del mundo.

¿Quién habla entonces?, ¿desde dónde se cuenta el relato?, ¿se consideran víctimas en todos los casos, en algunos de ellos o a partir de qué? Aunque la toma de posición, en términos de Bourdieu (1997), se asume en el testimonio, cuando se decide dar una entrevista, los lugares del relato implican entender las diferentes condiciones victimizantes de una comunidad, así ellas no sean plenamente conscientes de esto.

Un ejemplo encontrado tiene que ver con la condición de mujer, la cual es víctima de una cultura machista en la que, antes del proceso traumático, se daba por hecho la naturalización del oficio doméstico sin mayor derecho a opinar o participar de las discusiones del hogar o del entorno.

Otra forma de entenderlo se presenta cuando el testimonio se debe ver obligado a un lugar que aclare la noción específica del hecho victimizante, así este sea múltiple en diferentes momentos y en diferentes lugares.

En una de las entrevistas, al dar muchas vueltas sobre su testimonio y al contar cosas del pasado y del presente de manera desordenada, un reasentado de la ciudad de Pereira siempre matizaba con dolor y con cierta ambigüedad sus diferentes experiencias con la guerra, hasta que, en un instante y en medio de la conversación, hizo una pausa y halló cierto sosiego y consistencia en su relato cuando se le preguntó sobre un hecho puntual: «don José ¿cuál ha sido su relación con el tema de la desaparición?» a lo que respondió «Ese tema si lo manejo gracias a Dios con mucha propiedad, porque mi hermano cuando tenía 33 años fue desaparecido» [cursiva propia dada la particularidad que implica agradecer por un hecho tan doloroso en su experiencia de vida] (Irene, comunicación personal, marzo de 2013). Aquí, el relato habla de una identificación puntual 
de la condición de víctima en medio de una variedad de historias; al contrario de una insensibilidad frente a lo padecido, se presenta con claridad del hecho victimizante a narrar.

Por esto, otro criterio metodológico es ubicar la urgencia inmediata de la condición de padecimiento donde la toma de posición acude al sujeto en un marasmo de recuerdos, muchas veces, sin tramitar.

Así, un último indicador metodológico importante es evidenciar, en escenarios de violencia extrema como lo sucedido desde la desaparición forzada, una incapacidad de tomar la entrevista estructurada, semiestructurada o a profundidad como una herramienta suficiente para el relato de las «víctimas». Se diría, más bien, que es una técnica parcial y en constante revisión, la cual requiere complementarse como se hizo con otro tipo de instrumentos que amplían y ubican el lugar disposicional del actor, así como los cambios que pueden sufrir en su toma de posición, gracias a un testimonio dinámico, el cual no parte de un corte sobre el pasado padecido, sino sobre la continuidad de un presente que aún lo deja ante la no justicia, la no reparación y la posibilidad de repetición.

\section{La concreción metodológica}

Tener un orden secuencial, unos métodos y unas unidades de observación permite usar las categorías de análisis de manera clara no solo porque dilucida la relación entre lo teórico y lo práctico, a la hora del trabajo de campo, sino porque demuestra la viabilidad que tiene la investigación en un contexto determinado.

Inicialmente, se realizó un abordaje metodológico, desde el orden del discurso, con entrevistas semiestructuradas y entrevistas a profundidad. Todo ello bajo un horizonte etnográfico, el cual incluyó trabajo con grupos de familiares y miembros de la comunidad, diarios de campo y análisis documental.

De igual forma, se llevaron a cabo diálogos de localización subjetiva que, aunque conservan una estructura casi idéntica 
a lo que en etnografía se llama entrevistas a profundidad, tienen un horizonte hacia la guía de preguntas en un orden psicoanalítico. En ambos casos, se relacionaron elementos tanto en lo dicho, lo omitido, lo resaltado ante la palabra o lo demarcado con el silencio para establecer la distancia o cercanía entre el enunciado del sujeto y su disposición frente al fenómeno, pues se identifica, en algunos momentos, un lugar «borroso» del relato de lo sucedido.

El trabajo etnográfico permite identificar por medio de observaciones, diarios de campo, diálogos informales y análisis del discurso la construcción de sentido de la comunidad, los vínculos entre los trámites de las personas desaparecidas y las prácticas cotidianas, y las prácticas de resistencia o las formas de elaboración de duelos inconclusos.

El cuerpo ausente del desaparecido se presenta en las marcas de sus familiares, amigos y en la comunidad en general. En la memoria se reconstruye la pérdida que no deja de tornarse parcial ante la imposibilidad de un duelo que entierre aquello que no va a volver.

Respecto a la evidencia empírica, producida en el trabajo de campo, es importante destacar que parte de la información obtenida emergía a partir del acompañamiento realizado en algunas actividades de los colaboradores del proceso, lo cual permitía mayor empatía y creaba un ambiente más propicio para la narración de historias, anécdotas o experiencias que enriquecían cada paso.

Gran parte de estas informaciones se gestaban en diálogos informales. Fue evidente, en algunos casos, el interés de no querer plantearlas expresamente por medio de entrevistas, debido al tema abordado tanto por el dolor que evoca como por la seguridad que implica-, pues algunas de estas historias los comprometía o los hacía sentir inseguros ante la grabadora de voz.

Se realizaron entrevistas a profundidad, las cuales fueron fundamentadas en los criterios y el soporte conceptual que la definición del ritual y las prácticas de elaboración o trámite permitió construir. La definición de Gálvez (2008) ayuda a entender la importancia de 
la entrevista en la antropología y en las ciencias sociales en general, para él «... la entrevista cualitativa es una combinación acertada entre conversar e insertar preguntas, eludiendo en lo posible la directividad» (p. 3) y logrando un acercamiento con las unidades de observación y una posibilidad con el despliegue discursivo que esta herramienta puede generar en cada sujeto entrevistado.

En los diálogos realizados se pudieron estructurar las preguntas en relación directa con un concepto tan prolijo como lo es el ritual. Se dejó inicialmente una lectura libre sobre este concepto, pero, posterior a ello, se aclaró la naturaleza del mismo más allá del fenómeno religioso, pues esta es la idea más frecuente en los entrevistados; a la hora de responder por lo que les arroja escuchar esta noción.

Estas herramientas acordes con la naturaleza cualitativa de la investigación y el tipo de diseño etnográfico se presentaron como las más indicadas gracias a las condiciones propias del contexto; sean familiares o población víctima de desaparición forzada, muchos de ellos reasentados donde los hábitos y las formas de vivir, resistir, olvidar y no olvidar ponen, algunas veces, en evidencia aquello que muchos han querido dejar en el pasado, y no lo han logrado, o que han naturalizado como parte de su nueva forma de vida en el presente.

Rastrear una información empírica que hablara con las categorías de ritual y elaboración, en un fenómeno como la desaparición forzada, implicaba mucha versatilidad con el lenguaje a la hora de elegir la forma de transmitir las preguntas, pues el carácter intrusivo - en un tema de tanta sensibilidad - restringe las posibilidades del campo, en especial, con las precauciones de no instrumentalizar el lugar y la palabra del otro en un relato tan sensible.

Por ello, fue importante establecer una empatía adecuada con los colaboradores del proceso investigativo, así como con los contactos legítimos para la comunidad que, a partir de su trabajo y particularmente desde el acompañamiento, han demostrado su interés por ayudar y no solo por usar su drama en pro de beneficios particulares. 
Herramientas tales como elementos de observación para recolectar datos en formatos preestablecidos por variables y diarios de campo, los cuales garantizan la continuidad en el seguimiento, se cruzan con los diálogos informales, las entrevistas semiestructuradas y, a profundidad, garantizan consistencia y veracidad en el dato, ya que esta articulación permite una lectura más general y un panorama más integral frente al proceso.

Estos cruces de instrumentos obligan a ubicar metodológicamente un horizonte consistente. Por eso, se posibilita cotejar desde diversos ángulos algunos de los elementos recogidos empíricamente.

En ese sentido, el carácter propio del ritual y la importancia de la composición de la escena (símbolos, prendas, colores, accesorios, entre otros), tanto en los sujetos como en el colectivo, requieren destacar el papel jugado por la observación, además el adecuado manejo de las interpretaciones que esta podría evocar sin caer en juicios apresurados.

En consecuencia, se recurrió, en algunos momentos, a la observación indirecta entendiéndola desde la definición de Eyssautier (2006) donde esta «... consiste en tomar nota de un hecho que sucede ante los ojos de un observador entrenado, midiendo el comportamiento externo del individuo en sociedad» (p. 96); pues al tomar distancia con los involucrados, cuando era necesario no predisponer el comportamiento y el discurso, se buscaba obtener información a partir de su plena espontaneidad.

Es necesario destacar que en las visitas se utilizó este tipo de observación indirecta, además se invitaron otras personas al trabajo de campo que pudieran hablar y dar sus impresiones en diálogos diversos desde múltiples perspectivas disciplinares. Situación que permitió ampliar las lecturas construidas de manera individual.

Por último, en la recolección de la información se usó la revisión de prensa escrita y audiovisual medios locales y nacionales. Todo ello por medio de un diseño documental, a través de herramientas como 
el análisis de texto y el análisis de discurso, con el fin de realizar una lectura exegética de fenómenos que poseían contextos distintos, pero similitudes en el entorno o en lo conceptual.

Posterior a ello, se planteó una estructura de análisis que sustentara el desarrollo categorial desde la información recogida en el trabajo de campo. Toda esta colocación a partir de los hallazgos con la comunidad, los cuales fueron soportados desde lo planteado en lo teórico de manera comprensiva.

En el caso de la metodología con la antropología social, Velasco y Díaz de Rada (1997) dicen:

En el ámbito de la antropología social la referencia al "método" o a los "métodos" tiene generalmente significados diversos. Una descripción pragmática de la metodología aludiría al proceso de investigación como una secuencia que comienza con la preparación de un plan de trabajo y acaba con la elaboración y escritura de un informe, aunque tal vez habría que incluir también las repercusiones y reacciones que suscita en otros la lectura de ese informe (p. 17).

Entonces, mediante el proceso se comprende el recorrido realizado y el lugar de llegada del análisis cualitativo de un fenómeno - aunque sobre este exista diversa literatura en campos y escenarios múltiples-; para, con el producto final, dar apertura a un planteamiento que pueda abrir discusiones, nuevas preguntas u horizontes epistemológicos aún por explorar.

Es importante aclarar que las herramientas y su rol en la metodología no pueden perder de vista el lugar impreso por el horizonte teórico en todo el proceso, pues gracias a este se diseñó una recolección del material empírico, el cual fue delimitado a la luz de las nociones que tenían la categoría.

A continuación, se trabajó en la estructura analítica. En esta se clasificó la información desde los actores y las categorías centrales, y se hizo énfasis entre las nociones de viejos y nuevos rituales, los cuales 
se agruparon y se analizaron desde lo obtenido empíricamente. Dichas ideas enunciadas por la comunidad posibilitaron un acercamiento al concepto; de manera que este pudo evidenciar las características del ritual, a partir de cada caso y de forma implícita.

Por este motivo, leer el proceso desde la comunidad y la subjetividad llevó a utilizar sus narrativas y a usar los sustratos que traza conceptualmente el ritual, por medio de la experiencia dinamizadora (la desaparición forzada) no solo en el momento de lo sucedido, sino en todos los tiempos que este episodio trae consigo. En esta lógica, cada caso se analizó teniendo en cuenta momentos como el antes, el durante y el después del acto ritual; y aclarando que el acto es la concreción visible, pero el ritual es todo el proceso.

El paso final en el desarrollo metodológico fue hacia la escritura. Esta se realizó desde los componentes enunciados y a través de las unidades discursivas, la recolección de datos por medio de la observación y todos los insumos teóricos trabajados. 


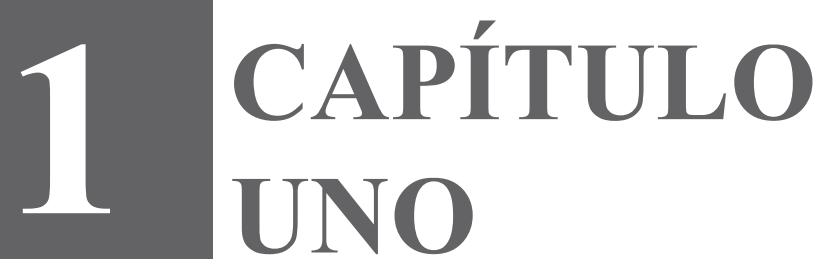




\section{Contexto histórico de la tragedia de vida a la tragedia cultural}

Te sueño тиy guapo [...] también por los años, pero nunca [...] nunca te imagino muerto Aura María DíAZ-AsfadDES

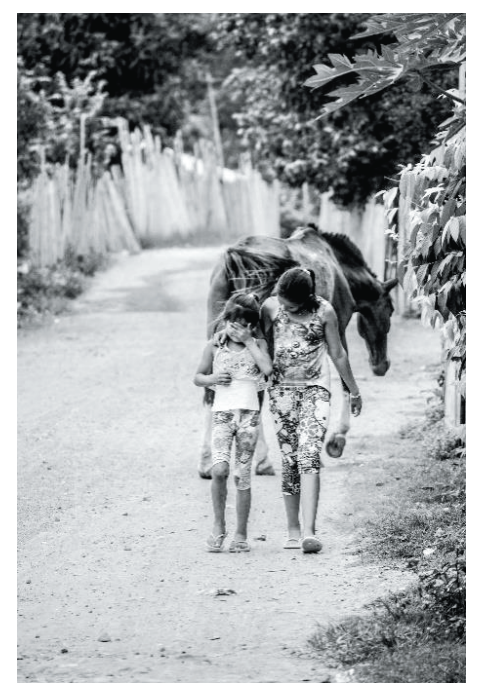

Fotografía por Jhon Hurtado.

No se puede desparecer aquello que nunca ha existido, lo que no se da como perdido y lo que no se reconoce; tal como sucede con la noción de ciudadanía, la cual, para su reconocimiento, necesita de responsabilidades del ciudadano y con el ciudadano. Pero, cuando la lógica de Estado no lo garantiza más que como sujeto nominal, en una guerra o en un proceso de desarrollo, la idea misma de actor social, miembro de o perteneciente a una nación, queda en incertidumbre.

Esta ha sido la constante en términos históricos en el desarrollo del país. La genealogía de este asume como inciertos a ciudadanos que no aparecen en un registro y, por lo tanto y más apropiado en términos 
legales, no existieron más que en el testimonio de sus familias, las cuales los vieron partir un día y nunca regresaron.

En este apartado se trabajaron inicialmente las definiciones centrales de la desaparición forzada, así como sus antecedentes más significativos. Se hizo un recorrido muy genérico por el marco jurídico que empieza a tipificar este delito y se enfatizó en el papel de la Segunda Guerra Mundial no solo en la formalización del estado de esta práctica, por medio de los decretos Noche y Niebla, sino por la expansión de la lógica que se implementó, así como la visibilización misma del delito, el cual, a mediados el siglo xx, era muy desconocido a nivel público.

Así mismo, en este capítulo se desarrolló una génesis inicial del fenómeno de la desaparición forzada en el caso colombiano. Se partió de los primeros marcos sociales que dan lugar a la comprensión de este acto, tanto desde el Estado como desde el ciudadano. Por último, se analizó de manera general, las lógicas del lenguaje de la desaparición forzada en términos simbólicos y se ubicó, como tiene que ver en Colombia, con una idea que va más allá de neutralizar, eliminar o sacar información a través de la tortura a un adversario como sucedió en Chile, Argentina o Uruguay.

En la sociedad colombiana se habla de un modus operandi, el cual no se inscribe en el desaparecido, sino en el lenguaje de muerte tejido en toda la comunidad como una idea de control político sobre los miembros de la población afectada; un control sobre el cuerpo social a través de lo que después del mensaje atroz de la desaparición se puede o no hacer en la cotidianidad de un territorio específico que, posterior a la incursión, queda sometido a la norma imperante de un victimario.

\subsection{Desapariciones forzadas, ciudadanos intangibles entre la guerra y el progreso}

La desaparición forzada, en el caso colombiano, se entiende como una práctica presente en el cuadro de un conflicto armado presente en el país. En esta se captura y, en muchos casos, se tortura a integrantes de una comunidad; sean estos activistas políticos, religiosos, comunitarios, 
actores de un bando en medio de una guerra o, simplemente, miembros de una población determinada.

La idea del desaparecer ha tomado distintos lugares en los imaginarios sociales a través del tiempo. En una época, a mediados del siglo XIX, el acto más misterioso en la magia era precisamente este, lograr que en medio del escenario el mago-encantador de la palabra se esfumara ante la mirada atónita del público, un espectáculo fantástico que consagraba a estos personajes, pues ese truco encantador siempre concluía con el retorno del mago o de su asistente y aparecer de nuevo era como un resucitar repentino que todos sabían iba a ocurrir.

El juego entre la vida y la muerte, el paso y el control del más allá, la sombra infantil de las cortinas dominada por estos astutos hechiceros fue cambiando en el tiempo. La «habilidad» fue arrebatada por la violencia política y, con ello, se invirtieron los mecanismos, los efectos y los espectadores; eran irrupciones violentas, retornos indefinidos y una audiencia forzada a interiorizar la desaparición forzada ahora no como recreación, sino como drama. La humanidad, al ser testigo y cómplice de ello, cambió por completo la noción del contendiente y del digno adversario, el corolario de esto no iba a tener nunca más un regreso al acto deslumbrante que, por un tiempo, fue el ausentarse entre sombras.

La práctica se hizo famosa en la escalada de persecución antisemita de Hitler en la Segunda Guerra Mundial. Por medio de un decreto firmado por él mismo el 7 de diciembre de 1941, cuyo nombre común fue el de «Nacht und Nebel», pero el título completo versaba como «Directivas para la persecución de las infracciones cometidas contra el Reich o las Fuerzas de Ocupación en los Territorios Ocupados», se buscó formalizar el primer decreto oficial de un Estado donde se legitimara la práctica de la desaparición forzada como mecanismo de defensa de este.

Dicha práctica tiene otros antecedentes previos al nacionalsocialismo, tales como lo sucedido en la guerra civil española donde una de las políticas más comunes del franquismo fue la desaparición forzada como 
mecanismo de intimidación a los opositores, ya que detrás del ejercicio de desaparecer se buscaba exhibir un lenguaje de control social sobre el otro, el cual no se limitaba a eliminarlo. Esta situación, en el caso mencionado, es coincidente con la práctica tan fuerte de persecución, aniquilación y sometimiento colectivo que, hasta el uso del lenguaje, era un medio de afirmar el poder.

Sin embargo, es en el decreto emitido por Hitler, por primera vez un Estado hizo pública su intención de controlar el cuerpo del perseguido, a partir de la desaparición como prescripción oficial.

Desde la Declaración de los Derechos del Hombre y del Ciudadano en 1789, esta opción se contemplaba casi como presagio de lo que sucedería iniciando el siglo xx. Se daba la posibilidad de que una persona pudiera ser castigada o detenida en contra de la autoridad y la ley establecida; aunque, al contrario, para el siglo mencionado la práctica terminó materializándose más con la responsabilidad y la complicidad, precisamente, de la misma autoridad. Es en esta época de grandes revoluciones que se mencionaba el castigo de este obrar de la siguiente manera:

Art.7. Ninguna persona puede ser acusada, detenida ni encarcelada sino [sic] en los casos determinados por la ley y según las formas prescritas en ella. Los que solicitan, facilitan, ejecutan o hacen ejecutar órdenes arbitrarias deben ser castigados (González, 1998, p. 267)

Dicha práctica no fue habitual en los periodos entre guerras que vivió el mundo hasta la guerra civil española y la Segunda Guerra Mundial, no porque no se usara como método de coerción contra el enemigo, ya que en casos como el colombiano las confrontaciones bipartidistas desde finales del siglo XIX e incluso antes dejaron un número indeterminado de desaparecidos gracias a la falta de garantías de un proyecto de nación en construcción, sino porque se populariza como recurso militar a finales del siglo xx. 
El ciudadano de esa época aún estaba expuesto a la confrontación, pero no al pleno reconocimiento de su identidad. Miles de personas murieron sin un registro de identidad que los particularizara como ciudadanos; entre estos muchos combatientes que nunca regresaban a casa. El fenómeno no se puede reducir a los costos de una organización en desarrollo en el caso del Estado, pues uno de los factores más importantes en la desaparición forzada de personas es el legado histórico, el cual familiariza de entrada con la idea del no retorno como una posibilidad común y quizá «natural».

Se debe aclarar que esta situación, aunque común en muchas latitudes por las dinámicas sociales de la época, se entiende más delante de manera comprensiva y focalizada en el propio contexto abordado, puesto que, a pesar de las similitudes, este tipo de fenómenos no se puede homogenizar sin atender las particularidades que contiene.

Retornando al contexto general, la práctica de la desaparición forzada a nivel mundial no se puede pensar, exclusivamente, como una tecnificación de la guerra y el suplicio moderno de la violencia, pues se desestimarían los criterios históricos que han servido como caldo de cultivo para la sedimentación de este propósito. Más bien, se podrían caracterizar tres escenarios globales de ella en términos históricos, al aclarar que no son los únicos ni los más representativos en todos los momentos, pero sí los más categóricos en la comprensión del fenómeno de manera deductiva, para enmarcar la experiencia colombiana.

Primero, la desaparición forzada entendida como la imposibilidad de las personas de regresar, vivas o muertas, con sus seres queridos. Esta fue común entre el siglo XIX y principios del XX cuando los proyectos emergentes de nación no tenían una estructura que reconociera la identidad de todos sus miembros y, por ende, el morir en combate o por una calamidad producto de ciudades en expansión territorial implicaba perder por completo a un sujeto, el cual nunca regresó, y atribuir su partida al infortunio hallado con la muerte o al quedarse indefinidamente en una de estas nuevas ciudades. 
Dicha situación no es anómala en relación con la categoría de desaparición forzada del Estado colombiano en la actualidad, ya que según este se considera el hecho solo en caso de violencia comprobada $\mathrm{y}$, en otro caso, se asume como desaparición voluntaria donde:

... la persona decide abandonar su lugar de permanencia sin informárselo a sus familiares o personas cercanas (motivada por razones personales, económicas, familiares o de alguna otra índole), como aquellas accidentales no causadas por la decisión autónoma de la persona de ocultarse o no ser localizada (Revista Forensis, 2015, p. 462).

Esta situación deja en entredicho la idea de desaparición y abre la puerta a la noción de ausencia de aquel que decide irse; lo que en el caso estadístico cuestiona mucho, debido a que en la realidad de la circunstancia, para el 2014 el $98 \%$ hacen parte de esas ausencias voluntarias y solo el $2 \%$ se asumen como desapariciones forzadas, aunque el mismo documento reconoce que gran cantidad de casos corresponden a jóvenes y niños al decir: «... esta conducta sigue concentrándose mayoritariamente en personas jóvenes (y también niños y niñas en los casos sin información) con niveles de escolaridad de educación básica primaria» (Revista Forensis, 2015, p. 461).

Todo ello al hacer las referencias a las desapariciones registradas, sean forzadas o no, ya que se debe tener en cuenta que muchas de ellas no aparecen declaradas, pues no se hacen denuncias por miedo o por falta de conocimiento del proceso.

En cualquier situación se entiende una influencia del legado histórico, desde el siglo XIX, el cual habla de una desaparición no registrada, no denunciada o, por lo menos, no sistematizada, la cual adjudica a hechos accidentales la desaparición. Consecuentemente, se dejan las investigaciones sobre lo que sucedió o sucede de manera inconclusa, lo cual no permite determinar el impacto real que estas situaciones tuvieron en la época y presentan en la actualidad. 
Segundo, la desaparición como práctica intencional de guerra. Uno de sus referentes históricos corresponde a los modelos implementados en el franquismo donde se contemplaba un mensaje dirigido tanto a los opositores, como a los familiares y allegados que pudieran pensar en hacer lo mismo que estos primeros hicieron. Empero, es importante aclarar que, a pesar del componente político de este fenómeno, gran parte de las víctimas de este flagelo son pobladores ajenos a la participación activa de un bando o del otro.

Este tipo de desaparición es, sin lugar a dudas, el modelo propio de Estados dictatoriales o sumamente represivos y de grupos armados donde el nivel de sevicia constituye un lenguaje básico para su accionar. Esta permite aquello que, desde un sistema colaborativo con la financiación de grupos paramilitares, muchos Estados integraron en sus políticas de control contra opositores o disidentes sin empantanar el nombre del mismo.

No es deliberado que, en ese mismo sentido, las primeras desapariciones forzadas oficiales en Colombia, entrada la segunda mitad del siglo xx, estén articuladas a grupos paramilitares con la complicidad o responsabilidad plena de las fuerzas militares. Esta situación, en buena medida, se debe al papel jugado por la Escuela de las Américas en lo atinente al ejercicio represivo de control estatal.

Desde esta plataforma se enseñaron, a las fuerzas militares, estrategias de guerra en las cuales la desaparición forzada, junto con grupos de contrainsurgencia, fueran un mecanismo eficiente en el terror sembrado hacia opositores y potenciales enemigos de la paz.

Tercero, la desaparición por decreto de un Estado legalmente constituido. Esta práctica, como lo fue el régimen dictatorial de la Alemania nazi, a diferencia de los dos casos anteriores, implica en una responsabilidad pública del Gobierno, el cual la asume como un mecanismo de control social, tal como lo buscaba el nacionalsocialismo alemán. 
Este tipo de comportamientos y responsabilidades de Estado afloran, en especial, después de ciertos juicios públicos posguerra sobre el papel de Estados comprometidos con diversas violaciones a los derechos humanos, lo cual tendría su propia expresión en América con las dictaduras a lo ancho del continente en la segunda mitad del siglo xx. Sin embargo, en varias de estas, la información establecida por el protocolo (decreto) de aplicación, por parte de las fuerzas militares, fue clasificada y, en ocasiones, tan compartimentada que nunca se conoció a la luz pública el alcance real más allá de declaraciones de testigos, sean estos víctimas o victimarios.

Vale la pena hacer hincapié en relación con lo señalado en el proyecto político nazi que, en el contexto de sociedades democráticas, hubiera bastado con la advertencia y el uso potencial de la fuerza para buscar dicho control. Tal como lo señala Berger (1967), respecto al uso de la violencia física indica: «... esta violencia final no puede emplearse con frecuencia. Antes de su aplicación, pueden tomarse innumerables medidas en forma de amonestaciones y reproches» (p. 101).

Más adelante, el autor complementa la información y dice: «... en cualquier sociedad en funcionamiento, la violencia se usa parcamente y como último recurso, ya que la simple amenaza de esta violencia final basta para el ejercicio cotidiano del control social» (p. 103). Sin embargo, la particularidad casi paradójica en la Alemania nazi es que el Estado fue cooptado progresivamente por el partido nacionalsocialista, a través de vías democráticas. Este representó legalmente la norma, situación que implicó llegar al poder por un proceso legal donde después pasó a negar su propia condición democrática, por medio de acciones antidemocráticas profundamente dictatoriales. No obstante, existe una diferencia de los Estados que hicieron lo mismo por medio de golpes militares directos, este hecho presentó un modo de operar distinto en el caso alemán, dado que obedeció a una estructura dictatorial, pero como lo señala el mismo Berger (1967), al ser un Estado legalmente constituido en un inicio.

Discernir estos tres modelos implica reconocer que la intención pretendida con la desaparición forzada varía según los contextos, su naturaleza es diferente y su aplicación también lo es, pero el resultado 
final es el mismo; el efecto de incertidumbre en la víctima, en especial familiares que muchas veces desconocen por completo estas diferencias causales, da cuenta de un significante común: la ausencia de un cuerpo que no regresa de ninguna manera y, el cual, en la mayoría de los casos, nunca se deja de esperar.

De igual forma, esta tipología caracteriza un primer registro histórico de aquello que desde siglos atrás se ha tornado como remanente del Estado, el cual es cuestión en la contemporaneidad.

\subsection{Un marco legal}

Las primeras resoluciones internacionales que buscan intervenir en el tema se dan tan solo hasta 1974. Por medio de la Comisión Interamericana de Derechos Humanos y la Comisión de Derechos Humanos de las Naciones Unidas, en 1975 se usó, por primera vez y por parte de esta última entidad, el concepto persons unaccounted for en relación con el fenómeno de los desaparecidos forzosamente en el conflicto separatista de Chipre. El término jurídico usado meses después es el de missing people. Entre un concepto y otro hay una dimensión semántica de aquello que no se puede contar cuantitativamente porque no aparece- y aquello incuantificable que está desaparecido; es decir, esta última se presenta como una noción más humanizada del fenómeno. Dichas resoluciones fueron tomadas por Naciones Unidas en su asamblea del mismo año, todo ello respecto a lo sucedido en Chipre y en Chile.

En ese último sumario, dos años después —en 1977—, la Asamblea de Naciones Unidas emitió la Resolución 32/118 y manifestó su preocupación ante el hecho. De igual forma, en 1979, la Organización de Estados Americanos (OEA) emitió una resolución respecto a lo acaecido en ese país, en ella inicialmente denunció el suceso, pero, al final, realizó una declaración ambigua, en la cual se instó a no promulgar leyes que encubrieran el delito. Esta falta de claridad se produjo debido a la presión política, la cual fue ejercida a la OEA por parte de la junta militar argentina. 
Un año después de la primera resolución de Naciones Unidas, en 1978, se promulgó la Resolución 33/173. Esta fue producto de los esfuerzos realizados, en buena medida, por el premio nobel Adolfo Pérez Esquivel, con el fin de denunciar la desaparición forzada de personas en la dictadura argentina.

Al respecto, el efecto legal se dio por presión de diferentes actores civiles, quienes, a nivel internacional, visibilizaron el drama ante el mundo, obligaron a que los organismos responsables asumieran un rol más claro y protagónico al respecto, y limitaron el control hegemónico de las dictaduras, en especial, a la hora de hacer, conservar o proyectar tratados comunes entre los Estados.

A pesar de que los años ochenta fueron bastante agitados a nivel mundial, tanto por el recrudecimiento de la práctica, como por el aumento de denuncias, la visibilización de lo sucedido a nivel global, las primeras condenas y los distintos intentos por enfrentar el tema por parte de algunos gobiernos democráticos o en tránsito hacia ello y también instituciones y organizaciones no gubernamentales; es solo hasta el año 1992 cuando se realiza, por parte de las Naciones Unidas, la declaración internacional respecto al tema, la cual abrió un escenario de discusión importante, pero dejó muchos interrogantes en la ejecución y las garantías legales en la aplicación de la misma.

Dos años después sería la Asamblea General de la OEA, en 1994 desde Brasil, la que elaboraría un instrumento jurídico más consistente con la Convención Interamericana sobre Desaparición Forzada de Personas (CIDFP); el cual, con veintidós artículos decretó un alcance y un compromiso más claro, por parte de los Estados miembros. Así, en el año 2006 se emitió la Convención Internacional sobre la Desaparición Forzada de Personas por parte de Naciones Unidas y, en el 2007, se firma oficialmente.

Aunque la legislación internacional contempla el énfasis de la desaparición forzada como un acto en contra del sujeto, el cual es ejecutado por el Estado o con la anuencia de este; los pliegues políticos de lo sucedido, en algunos países de Centro América y Suramérica, 
ubican este modelo de guerra en los años ochenta y noventa, como un patrón de escalamiento del conflicto, en especial por grupos narcotraficantes en las conocidas guerras entre cárteles.

En ese sentido, si bien el asesinato es el lenguaje más frecuente, las desapariciones empiezan a tornarse como mecanismos de acción y reacción entre estos grupos. Es por eso que la Ley 589 del 2000, en el caso colombiano, plantea:

Artículo 268-A. Desaparición forzada. El particular que perteneciendo a un grupo armado al margen de la ley someta a otra persona a privación de su libertad cualquiera que sea la forma, seguida de su ocultamiento y de la negativa a reconocer dicha privación o de dar información sobre su paradero, sustrayéndola del amparo de la ley

Aquí la norma se diferencia de la mayoría de las legislaciones internacionales, ya que se amplían jurídicamente las posibilidades de que la desaparición forzada sea responsabilidad de actores distintos al Estado. Todo ello sin desconocer el papel primario que ha jugado esta institución en Colombia, donde el porcentaje más significativo de desapariciones forzadas, con sus efectos sociales y políticos, viene de parte o con la complicidad de este mismo; no solo desde episodios visibles con culpables públicos como en las dictaduras, sino en las aparentes democracias estables de América Latina como es el caso de Colombia. En este país, el rol del Estado es más delicado jurídicamente que el de cualquier otro actor social, por ejemplo, la referenciada Ley 589 (2000), en su artículo 268-B, indica que existirá agravación punitiva: «Cuando la conducta se cometa por quien ejerza autoridad o jurisdicción», siendo claro que dicho crimen presenta una mayor gravedad cuando el responsable por acción directa o complicidad es el Estado, sin demeritar la gravedad de la situación con otros grupos armados, pero al aclarar el papel primario que, en cualquier democracia, debe jugar el Gobierno que regenta en nombre de lo estatal. 


\subsection{América Latina}

Colonizar, como la experiencia de arrasamiento étnico, trae por atributo implícito la desaparición de personas en el marco del exterminio que este territorio vivió. El etnocidio no fue al principio mestizaje, fue la aniquilación de poblaciones enteras no solo en cuanto a lo físico, sino en cuanto a lo simbólico y lo social. Pensar la génesis del tema en el contexto de América Latina arroja, de manera ineluctable, al proceso de conquista, el cual, de forma particular, se padeció en cada territorio, pero donde la idea de secuestrar, abandonar, martirizar y desaparecer tiene sus primeros pinos.

La falta de información, debido a lo desperdigada que se encuentra, implicaría otra investigación dedicada a ello, la cual recopile datos y pegue trozos de historia invisible que hablen de la crueldad de lo sucedido en esta época. Por ahora la delimitación de esta experiencia en América Latina solo se planteó en el caso colombiano, gracias al alcance profundo que esto requeriría. Para el cuadro continental se retomará al ser coherentes con lo posible y al tener en cuenta únicamente un recorrido a partir del siglo XX.

Al revisar la desaparición forzada en Latinoamérica, se encontraron antecedentes desde la desaparición de cadáveres en El Salvador en 1932, tras las masacres perpetradas por el régimen de Hernández Martínez. Sin embargo, el método como tal empezó a configurarse en Guatemala entre los años 1963 y 1966 (Amnistía Internacional, 1987). Investigaciones como las de Galeano (1967) relatan lo siguiente:

En marzo de 1966, en medio de los preparativos del traspaso del gobierno a un civil electo, el abogado Julio César Méndez Montenegro, fueron capturados y desaparecidos 28 dirigentes políticos y populares e intelectuales opositores. Sus cuerpos jamás aparecieron. Posteriormente se logró establecer que habían sido capturados por órdenes del entonces ministro de la defensa, el coronel Rafael Arriaga Bosque. Torturados hasta la muerte, sus cadáveres fueron arrojados al mar desde aviones de la Fuerza Aérea (p. 32). 
En esta misma época, 1964, en el desarrollo de la militarización del Estado brasileño, se empezaron a registrar las primeras desapariciones políticas en este país, las cuales fueron producto de lo que el informe del Nunca Mais llama como «época de incertidumbre». Allí se redacta lo siguiente: «... um instante de indefinição acerca de qué grupo entre as forças armadas — não inteiramente homogeneas - assumiria o comando mais direto do aparelho de estado» (Nunca Mais, 1985, p. 53).

El Salvador vuelve a aplicar esta práctica en 1967 de la mano de militares activos en ese entonces y con el denominado grupo Organización Democrática Nacionalista (ORDEN) que, en 1970, se constituyó oficialmente como parte del Estado salvadoreño hasta 1979, año en el cual se suponía quedaba disuelto, pero en la práctica siguió operando como un grupo paramilitar por varios años más.

Amnistía Internacional hizo alusión, para América Latina, de dos formas de entender la desaparición forzada en esta época. Primero, la ejecutada por grupos mixtos respaldados por el Gobierno, pero de naturaleza paramilitar, pues dicho respaldo en apariencia no fue oficial, tal como lo mencionado sobre El Salvador y lo ocurrido en Guatemala. Segundo, la desaparición forzada completamente controlada por el Gobierno, en especial por las juntas militares de países como Chile, Argentina y Uruguay.

Este último modo de operar implicó dictaduras bajo un aparente manto de legalidad, lo cual tejió un vacío jurídico entre la ley interna y la jurisdicción internacional, tal como lo señala Gutiérrez y Villegas (1998) respecto a regímenes del cono sur al decir: «... se materializaron a través de diferentes figuras delictivas tales como detenciones ilegales y secuestros, seguidas en la mayoría de las ocasiones de homicidios, asesinatos y desapariciones forzadas, previa tortura de las víctimas» (p. 35).

Para este periodo, el límite entre lo legal y lo ilegal en relación con las prácticas de control y disciplinamiento sobre el otro lo determinó el mismo Estado de manera interina, al apelar a la razón autosuficiente de este (Foucault, 2008). Por tal motivo, el contacto con otros países no 
posibilitaba claramente una lectura crítica sobre la situación, sino una especie de diplomacia cómplice de delitos de lesa humanidad.

Cuando se aceptó jugar un mundial en Francia, en medio del expansionismo nazi en 1938, en el que inclusive Austria no participó por estar recientemente ocupada por Alemania - lo que indica que el ambiente de la Segunda Guerra Mundial se había incubado-, se legitimó en el nombre del deporte un estado de aparente calma y hermandad, el cual escondía, tras de sí, una realidad brutal que acechaba al mundo en ese momento.

Esta historia tiene su propio relato en Suramérica con el desarrolló del Mundial de futbol de Argentina en 1978; allí eran claras las denuncias que implicaban a los anfitriones, hasta el punto de que organizaciones de derechos humanos veían en el evento la posibilidad de hacer público lo que ya se conocía en el mundo respecto al genocidio en manos de la junta militar, empero, la participación de varios países «democráticos» terminó igual que en 1938, al avalar la naturaleza del Estado organizador del encuentro deportivo.

De esta forma, la legitimidad determinó un grado de complicidad política que dejó una sombra de legalidad para los perpetradores y de impunidad a nivel internacional. Con la entrada de los años ochenta y la caída de algunas de estas dictaduras, fue claro el rol del Estado, pues sobre este giraron las posibilidades de juicio y reparación. Por tal razón, algunas de las condenas proferidas internacionalmente en esta época fueron sobre actores gubernamentales de Chile, Argentina y Uruguay.

Aquí el interés, en buena medida, se concentró en la idea de un cierre de estos episodios con unos culpables identificados y una búsqueda de garantías de no repetición. Sin embargo, los matices propios de cada territorio, a pesar de que implicaron comprender un contexto particular que habla de los diferentes lugares con sus respectivas características, al referirse a delitos como la desaparición forzada y al investigar una perspectiva situacional como la colombiana, pudo ayudar a una caracterización del fenómeno y a una representación de elementos comunes y diferenciadores en una experiencia desafortunadamente inconclusa. 


\subsection{El caso colombiano}

Previamente se planteó un sustrato base en el que se reconocen algunos de los referentes por medio de los cuales la sociedad colombiana ha vivido, en términos históricos, el fenómeno de la desaparición forzada. Dichos elementos son responsables, en buena medida, de la base en la cual el tema se erige tanto en lo político - desde el Estado y sus actores - ; como desde lo cultural, a partir de la naturalización de cierto tipo de prácticas. No obstante, se aclara que estos criterios -el político y el cultural - terminan siendo indisolubles para dimensionar, desde lo histórico, la comprensión y el alcance real de este tipo de experiencias.

Si en la metodología se ubica el lugar de la disposición de un actor en cuanto a su relato, desde la posición hacia la toma de posición en un campo especifico. Al seguir a Bourdieu (1997), es importante entender este proceso desde un corpus social, no solamente desde la narración subjetiva, sino desde la caracterización colectiva y territorial del fenómeno, el cual varía en episodios históricos, pero se debe leer desde la modelación de cada momento temporal, como desde su legado en momentos posteriores.

Como lo señala el mismo Bourdieu (1997): «En todo caso, en fase de equilibrio, el espacio de las posiciones tiende a imponer el espacio de las tomas de posición: las transformaciones profundas del espacio de las tomas de posiciones» (p. 4), así no se puede eximir responsabilidad en la toma de posición, pero tampoco negar que el espacio de las posiciones incide en esta de manera categórica.

El campo social de la época deja en evidencia la poca capacidad de acción de las diferentes instituciones internacionales en los años setenta y ochenta, lo cual posibilitó que el delito de la desaparición forzada pudiese guardar márgenes amplios de complicidad en los diferentes países.

Colombia, al no ser exenta de esta disposición, vivió en este período un proceso de recrudecimiento de la violencia, en especial con modelos de operar más fuertes por parte de grupos estatales y 
paraestatales. La desaparición forzada empezaba a ocupar los primeros lugares en el modus operandi de dichos actores armados y, de forma significativa, dicha estrategia de guerra fue usada en contra de algunos grupos de resistencia armada, grupos políticos de izquierda y diferentes organizaciones sociales.

A pesar del precedente que esta época visualizó, tan solo hasta la Constitución de 1991 se oficializó en el país el derecho a no ser desaparecido. Este fenómeno, como delito en el código penal, solo apareció hasta el año 2000. Sin embargo, la desaparición forzada de personas en Colombia no se manifestó a partir de los años ochenta; el primer caso registrado oficialmente es de 1977 por parte de Omayra Montoya, la cual era militante del Ejército de Liberación Nacional (Centro Nacional de Memoria Histórica [CNMH], 2014).

Dicho caso marcó una pauta de análisis particular, pues como primer proceso denunciado oficialmente, no fueron fortuitas algunas variables en esta desaparición tales como la libertad posterior de su novio, quien también había sido secuestrado en la misma escena, y la condición de género en un delito de esa naturaleza. Empero, antes del caso de Omayra Montoya, se deben tener en cuenta algunos de los elementos planteados, aquellos formaron los primeros dispositivos históricos de la desaparición forzada de personas en Colombia, como parte del constituyente disposicional.

Como se mencionó en la tipología formulada párrafos atrás, una de las causas de la desaparición forzada en Colombia se presenta desde principios del siglo XIX donde, al no tener un sistema de identificación nacional, el país desconoció varios años en los cuales se presentó el acto de desaparecer forzosamente. Esta situación se naturalizó a la par del expansionismo, de las guerras y de la colonización de nuevos territorios. Por eso, la falta de información al respecto es, precisamente, una carencia de preocupación por el tema en la época, pues como todo país en vía de desarrollo, la itinerancia de los actores sociales; la búsqueda de nuevos horizontes y los conflictos invisibles, pero latentes por el control de terrenos, colonizaciones y expansiones, implicaron 
una cierta ambigüedad en el lugar del otro que se fue, se organizó en otro lugar, se reasento o, posiblemente, desapareció en una situación incierta.

De esta forma, se reconoce que, sobre el tema, se desconocen siglos de información; ya que, el no retorno por causas sociales o políticas no se puede estudiar al obturar la mirada solo desde un punto de la historia nacional, ni al desconocer los elementos previos que, de una u otra manera, son sedimento para la naturalización de esta práctica en generaciones posteriores; situación no solo desde la asimilación del acto, sino desde la responsabilidad real del Estado en todos los procesos históricos de violencia.

Al respecto, Halbwachs (2004) señala que todos los marcos sociales están en la memoria, que no hay nada que no haya pasado por allí, que al igual que con los sueños, pueden articularse deseos o imágenes, aparentemente ajenas al acontecimiento, pero que, finalmente, todo se encuentra compuesto por una consciencia, la cual ha inscrito en dicha memoria diversas experiencias.

De esta manera, es importante atender dos cuestiones: primero ¿qué tanto de ese pasado interviene en la modelación cultural del fenómeno de la desaparición forzada como una práctica inscrita en la lógica de un conflicto en la contemporaneidad? Y, segundo, ¿de qué manera se pudo sedimentar, en el contexto histórico colombiano, un fantasma anónimo y cuerpos sin retorno, los cuales tienen antecedentes sin calcular y hacen parte de una herencia social no reconocida políticamente? Al fin y al cabo, a pesar de no tener nombre hasta el siglo xx, la desaparición forzada no dejó de ser un espectro que ha aterrorizado desde centenios atrás y que se ha insertado, quizás sin saberlo, en la cotidianidad de forma natural.

En ese sentido, se debe reconocer que los primeros registros de desaparición forzada de personas, por motivos políticos, se presentaron en la conquista donde comunidades indígenas fueron asesinadas, desplazadas y desaparecidas sin tener mayor identificación nominal de cada uno de estos casos. Se partiría por entender, a partir de esta 
experiencia, el primer marco histórico de la memoria que, como lo señala Halbwachs (2004), desde las prácticas precursoras de los fenómenos sociales, determinó un precedente que después intervino en la construcción de los marcos sociales futuros.

Así, la comprensión del conflicto implica sociedades que deben entender, en prácticas como la desaparición forzada, un fenómeno en dos sentidos: por un lado, la necesidad de reconocer la identidad del desaparecido y su condición básica de ciudadanía a partir de un nombre $\mathrm{y}$ un cuerpo que dignifique su lugar como habitante de un territorio y como agente social con derechos; vivo o muerto, pero presente. Por otro lado, una sociedad que no puede invisibilizar siglos de violencia, los cuales han marcado una historia; han dejado una huella y hacen parte fundamental del legado social y, por ende, disposicional que no se puede reducir - únicamente - en pesquisas de algún historiador, el cual naufraga entre los pocos archivos de las épocas de la Colonia.

Reconocer como punto de partida la desaparición forzada desde la época de la Conquista, situación que define un primer insumo al campo que la sedimenta, implica dignificar el lugar del nativo, pues este se enfrentó a la usurpación de su territorio y su identidad. El desplazamiento, el asesinato y la desaparición son entonces prácticas comunes producto del campo en disputa donde, después de la conquista, los procesos de levantamiento indígena, así como el papel de estos junto al de los mestizos en el proceso independentista no es destacado o visibilizado de manera clara en la historia de los Estados modernos.

Más allá del genocidio y el etnocidio propios de la Conquista, al igual que los costos sociales del proceso de independencia, es importante entender que los primeros episodios de desaparición forzada llegaron de la mano con los niveles más altos de recrudecimiento de la violencia en esta época. Más allá de la muerte física, fue la negación de la existencia histórica de un actor social, el cual ingresó en una estadística aún desconocida y caracterizada por la imprecisión de los datos, los cambios vertiginosos en la toma del poder, los conflictos territoriales y la muerte como parte de un proceso de construcción de nación. 
El proceso de independencia no trazó un límite de la violencia social y política, como tampoco en las prácticas usadas en la misma. Si bien acabó parcialmente con el control español y cimentó un nuevo sistema de gobierno, las tensiones al interior conllevaron a un continuo enfrentamiento entre centralistas y federalistas y, posterior a ello, entre liberales y conservadores, el cual perduraría por mucho tiempo. En palabras del mismo Mariano Ospina Rodríguez en 1848, ideólogo conservador de principios del siglo XIX, citado por Tirado (1995):

El partido de la Independencia tuvo la desgracia de dividirse cuando más necesitaba la unión. La forma de gobierno que debía darse al país fue la causa de la discordia. Quisieron unos la federación, otros el centralismo [...] Cuando Bolívar expuso sus opiniones en un proyecto de constitución para Bolivia, y las recomendó a América, este malhadado proyecto fue la manzana de la discordia; a su vista los granadinos, como el resto de los colombianos quedaron divididos en dos grandes bandos [...] Ese día los amigos de la independencia se denominaron: bolivianos y liberales (p.29).

Esta confrontación se postergó por varios años. En ellos la violencia bipartidista aumentó la capacidad de acción a través del lenguaje de la guerra, el cual fue más allá de la muerte y la desaparición forzada como una de sus expresiones, pues esta se mimetizó en la noción de «conflictos», lo cual generalizó el fenómeno y no permitió comprender la dimensión real de la misma y, mucho menos, tener un aproximado de ciudadanos desaparecidos en el conflicto y en la historia del país de manera directa e indirecta.

Episodios como la Regeneración, periodo conservador entre 1880 y 1910, marcaron hitos de violencia y autoritarismo estatal que, a pesar de regularse parcialmente en algunos momentos al principio del siglo $\mathrm{xx}$, volvieron y atizaron en momentos posteriores, tal como pasó en el caso del Bogotazo en 1948 o en la época de la Violencia en los años cincuenta y ochenta. 
Si bien es importante tener en cuenta que los decretos Noche y Niebla, emitidos por la Alemania nazi, fueron unos de los precedentes oficiales que legalizaron el papel de la desaparición forzada; también es fundamental mencionar que, mucho antes de la Segunda Guerra Mundial, en la época de la Regeneración conservadora en Colombia y en la Constitución de 1886 de este mismo país se abrió la puerta para que prácticas de control por parte del Estado fueran usadas como instrumentos políticos para desaparecer y asesinar opositores.

Amparados en el artículo 28 de dicha carta magna de 1886 se expresó:

Esta disposición no impide que aún en tiempo de paz, pero habiendo graves motivos para temer perturbación del orden público, sean aprehendidas y retenidas, de orden del Gobierno y previo dictamen de los Ministros, las personas contra quienes haya graves indicios de que atentan contra la paz pública (Constitución Política de Colombia, 1886, p. 15)

El artículo 29 de esta misma constitución volvió a incorporar la pena capital en el Estado y dio como resultado la agudización de las prácticas de violencia por parte del Gobierno, tales como las respuestas proporcionales de los opositores radicales.

La pena capital que tan solo se suspendió oficialmente hasta entrado el siglo $\mathrm{xx}$, junto con la desaparición forzada, la cual continua siendo un mecanismo estatal y para estatal en la actualidad ${ }^{2}$ fueron inscritas en ese marco histórico que, por un lado, ve en la venganza, con el asesinato del otro, un mecanismo de castigo y de ejemplo para ciertos delitos y; por otro, naturaliza la dicha desaparición hasta el punto de hacerla casi imperceptible en el ejercicio cotidiano de la violencia social.

2 Para ello ver lo acontecido en el marco del estallido social del año 2021 en Colombia. En este se sistematizaron casos de desaparición forzada, los cuales se presentaron en diferentes lugares del país. Para efectos de claridad y contexto se menciona uno de ellos: el informe entregado por la Defensoría del Pueblo, el Comando Departamental de Paro, la Personería de Pereira y la Comisión de la Verdad para el Eje Cafetero (2021) donde se señala lo siguiente: «Así para la primer variable de Desaparición, desde el Comité departamental del Paro se presentó 112 reportes, Personería 112, procuraduría 2, defensoría no presenta, la UTP 24, el Comité de derechos humanos 16, la Fiscalía 0 y el observatorio civil de DDHH 17» (Comisión la Verdad, 2021, p. 5). 
Dicho contexto histórico tiene picos mayores y menores en el siglo Xx y continúa presentándose en la actualidad. De este se anudan tres elementos parciales en el eslabón social del país, los cuales influencian fuertemente la memoria colectiva construida, de manera consciente o inconsciente, en el discurrir propio del tejido político colombiano.

Primero, la desaparición forzada como una cuantificación incierta y en disputa permanente sobre número real de desaparecidos. Segundo, el ritual como un recurso simbólico de víctimas para enfrentar la incertidumbre de la espera y, de victimarios, para enunciar un nuevo lenguaje sobre el cuerpo del otro que, paradójicamente, no tiene que ver con lo físico; de igual forma, un Estado que pretende dar continuidad a un proyecto de nación bajo la tipificación de cuerpos ausentes, los cuales pueden ser buscados en relación con otros que ni siquiera existen. Tercero, la angustia como un malestar difuminado entre los peligros externos, estos muchas veces reprimidos bajo la justificación de una consecuencia del destino o de las bajas «normales» de una guerra.

Este último elemento se entiende como parte de los peligros internos que impiden asumir una búsqueda, debido al miedo a la persecución o al asesinato $\mathrm{y}$, adicional a ello, a la indiferencia, ya que es buscar aquello que el Estado no da siquiera por ausente. Contrario a lo mencionado por Freud (2006) donde «... sabiendo que el desarrollo de la angustia es la reacción del yo ante el peligro y constituye la señal para la fuga» (p. 2374) no se presenta esta última, no es posible huir de aquello que habita y amenaza física y simbólicamente al sujeto y no es factible distanciarse, pues la angustia se presenta entre la espera del ausente; el miedo a la persecución; y por medio de un proceso de violencia aún no terminado y una sintonización entre la espera, el miedo y la responsabilidad de pensar o no en lo que se debe hacer.

Así, los tres criterios generales, si bien más adelante se problematizan respecto a la perspectiva de la desaparición forzada en la contemporaneidad, son sustrato fundamental en la naturaleza del proceso histórico en el marco del siglo anterior. 


\subsection{Del primer caso «oficial» hacia una historia sin fin}

El 4 de noviembre de 1982, la Procuraduría Delegada para la Policía Nacional profería su fallo disciplinario. La Procuraduría Delegada concluyó que la señorita Omaira Montoya Henao sí fue capturada por unidades de la Policía Nacional el 9 de septiembre (CNMH, 2014).

Omaira Montoya fue capturada, junto con Mauricio Trujillo, el 9 de septiembre de 1977 en Barranquilla. Tanto el informe de la Comisión de Memoria Histórica ( $\mathrm{CMH}$ ) como organizaciones no gubernamentales y entidades internacionales tomaron este caso como el primer antecedente oficial registrado de desaparición forzada en Colombia. Archivos y documentos han permitido visibilizar la historia de lo sucedido; sin embargo, es importante tener en cuenta, en el imaginario social de lo que pasó, varios elementos simbólicos más allá de los concretos de la desaparición, rasgos bastante cruentos en una práctica que por su naturaleza misma es dramática.

No es fortuito que el primer precedente oficial de desaparición forzada en el país sea el de una mujer que, adicional a ello, estaba embarazada y al día de hoy, después de tantos años, su paradero sea aún incierto; aunque existan personas condenadas por el hecho.

La desaparición forzada deja pocos cabos sueltos, ya que es un mensaje dirigido, más que al mismo desaparecido, a aquellos actores que rodean lo rodean. Aquí se puede tomar distancia de experiencias como la Argentina donde la desaparición, en su momento, tuvo una finalidad dirigida, en buena medida, hacia la delación, pues tal como lo señala Schindel (2012):

El propósito manifiesto era obtener rápidamente información que permitiera realizar nuevos secuestros; pero según los testimonios muchos detenidos siguieron siendo torturados durante días, semanas o meses. También se practicaron torturas psíquicas como los "simulacros de fusilamiento", la exhibición de la tortura de conyugues, padres o hijos, y las mismas 
condiciones de cautiverio, sumadas a la tortura y destrucción de sus compañeros de detención, consistían en un tormento psíquico adicional (p. 33).

Por su parte, la desaparición en el actual contexto colombiano tiene una finalidad de control biopolítico sobre la comunidad: sembrar el reino del terror con una tragedia más allá de la muerte, puesto que es más difícil implementar esta práctica que optar por asesinar un actor específico y ganar a mediano y corto plazo la efectividad de un mensaje más contundente a través de la incertidumbre y el desconcierto, cada decisión implica una consecuencia simbólica que va desde elegir a quién desaparecer, cómo hacerlo y definir su retorno o no. Como lo formula Blair (2010), a propósito de la violencia irracional en Colombia,

... el cuerpo es, no sólo [sic] su materialidad, sino que está cubierto de significaciones culturales. La masacre es algo así como una "profundización del dolor" que apela a otros lenguajes y a otros códigos de comunicación, para hacer efectiva su estrategia de terror. Los efectos sobre las poblaciones parecen así mismo destinadas a esta graduación o profundización del dolor (p. 172).

Cada acción es premeditada y con cada una de ellas se busca un mensaje público, el cual es diseñado para promover el control del cuerpo social e, inclusive, para dominar sus propias decisiones sobre las consecuencias dolorosas del desacato y conservar la angustia por medio de la cotidianidad.

Algo similar sucedió en el proceso interminable de desaparición forzada en Trujillo, Valle del Cauca, donde dicha práctica se inició con la desaparición del sacerdote de la comunidad Tiberio Fernández y su sobrina Ana Isabel Giraldo, lo cual dejó claro, de entrada, que no era aleatoria la decisión de iniciar esta cadena de crímenes; justamente por ser cometidos con un sacerdote y no con un combatiente. De esta forma, difícilmente se puede pensar que desaparecer a Omayra Montoya haya sido un asunto solo circunstancial. 
En ambos casos, posterior al hecho, se desencadenó, de manera sistemática y casi naturalizada dentro del lenguaje de la guerra, la práctica de la desaparición como medio de control ejercido sobre cualquier persona; independientemente de la importancia simbólica que poseía para la comunidad. En las dos historias no era aleatoria la desaparición de actores sociales que tenían, en el imaginario cultural, una protección más significativa que la de un miliciano o un acusado de auxiliar a la insurgencia, tal fue la situación de Omayra, mujerembarazada y acompañada de su esposo; o la del padre Tiberio, sacerdote de la comunidad, el cual estaba en compañía de su sobrina.

Fue un mensaje de entrada culturalmente transgresor. El discurso del control sobre la vida y la muerte tomó forma e hizo efectiva la desaparición sobre un cuerpo femenino y, además, en gestación. La contundencia no estaba en la practicidad del asesinar, sino en el suplicio del no retornar y, con ello, la negación de elaborar la pérdida y mantener en vigilia la angustia y el miedo bajo un mismo horizonte psicológico.

La primera negación política de Omayra no solo fue sobre su cuerpo atado a una identidad, sino sobre su condición de género. Los documentos iniciales hablaron del operativo, de los agentes que intervinieron, de los testigos y de la captura de Mauricio Trujillo; pero ella no aparecía de ninguna manera. Fue como si, de forma un poco premonitoria, después de declarar su desaparición se supiera la suerte que correría, pues el registro inicial le arrebata su identidad básica como ciudadana, un lugar, un nombre y un cuerpo.

La época posterior al caso de Omayra Montoya sembró, como método común, la desaparición forzada de personas aunque, como se ha mencionado, no apareció por primera vez en esta fecha. Esta práctica sí comenzó a ser parte de un lenguaje vehemente sobre el cuerpo social de una comunidad; sobre la imposibilidad de morir y sobre el calvario de la incertidumbre no como una afrenta física, sino simbólica.

El patrón cultural se combinó desde dos aspectos para demostrar la efectividad de este fenómeno, por un lado, tuvo en cuenta el resultado del duelo inconcluso como recurso fundamental para continuar - algo 
propio de la tradición religiosa y cultural - y, por otro, dispuso del aún imperceptible marco histórico que hablaba de la desaparición desde muchos siglos atrás.

De una u otra forma se sedimentó la idea de la identidad, del derecho a la ciudadanía y de la naturalización de la muerte y la ausencia como parte del legado social. Esta situación indujo a la pregunta sobre ¿qué tanto de ese precepto de Halbwachs, que sitúa la memoria y retiene, pero no olvida, implica la forma como se han relacionado las personas con un tema que aún es parte de la cotidianidad?

Entre los ochenta y los noventa, las dimensiones de esta tragedia adquirieron tal magnitud que se perdió la posibilidad de particularizar cada acto. Por esa razón, la Comisión de Memoria Histórica (CMH) en el informe entregado sobre el tema en el 2013, enmarcó la temporalidad comprendida entre 1970 y 2010 , y solamente desarrolló la historia de trece desaparecidos.

Cada una de las reconstrucciones de estas historias de desaparición en Colombia se convirtió en una suerte de estudio de caso, en medio de un fenómeno con datos aún por establecer. Según el Registro Único de Víctimas (RUV), los datos se aproximaron a 161967 personas desaparecidas; no obstante, los relatos trabajados por la $\mathrm{CMH}$ fueron los de Omayra Montoya, Miguel Díaz, Luis Fernando Lalinde, Víctor Isaza, Nidya Erika Bautista, Amparo Tordecilla, Alirio Pedraza, Oscar Tabares, Ángel Quintero, Claudia Monsalve, Simón Gonzales, Alex Vargas y Sandra Cuellar.

La complicidad del Estado y su inoperancia en muchos de estos casos implicó que, tan solo hasta la fecha, se empezara a tener una sistematización un poco más juiciosa del fenómeno; aunque se partió de una premisa inverosímil como derecho ciudadano: contar los desaparecidos únicamente a partir de las denuncias desde 1985 y asumir, con base en unos estimados y algunos pocos registros, un total de 28747 víctimas de desaparición antes de esta fecha; dato bastante lejano de la realidad debido a lo antes expuesto. 
Lo llamativo no fue lo pragmático del dato, sino dar por cerrado el proceso de seguimiento y cuantificación de víctimas que se hayan presentado antes de 1985, es decir, no buscar más a aquellos «sin nombre-sin derechos», los cuales fueron desaparecidos antes de esta fecha estimada por el Gobierno. Si bien en procesos como el de Argentina se presentaron similitudes, pues como lo indica Schindel (2012) para el momento

Resulta significativo que pese al intenso trabajo de investigación y elaboración colectiva que ha tenido lugar en la Argentina se carezca hasta el día de hoy de información cabal sobre los desaparecidos. ¿Dónde están sus restos? ¿Cuántos desaparecidos hubo? ¿O debemos decir cuántos "hay"? A pesar de las múltiples y complejas formas en que ha sido abordado el pasado dictatorial en los últimos años estas preguntas aún no pueden responderse (p. 34).

Es importante aclarar que para Colombia se comparten los mismos interrogantes respecto al dato real, pero no ha existido una finalización del conflicto y, mucho menos, un reconocimiento de la responsabilidad del Estado sobre este; salvo en algunas excepciones, lo cual no hace más complejo el tema, sino que lo sitúa en perspectiva diferente.

Volviendo sobre la estadística en Colombia, según lo mencionado por el RUV, el dato total de personas afectadas por desaparición forzada en el país es de 161967 hasta el 1 de abril de 2021. No obstante, si se excluyen las víctimas antes de 1985, el dato es de 133220 (RUV) en 31 años, cifra que refleja una realidad importante, pues destaca cómo en tan solo tres de esos años, desde 2001 hasta 2003, se concentró el 28.2 $\%$ de los casos. Se tuvo el punto más alto en 2002 con 14544 personas desaparecidas; todas ellas en el marco del gobierno de Álvaro Uribe Vélez, personaje defensor de la persecución de la insurgencia por vía armada y sin interés alguno en negociación.

La mayoría de hechos de desaparición forzada en el país no son registrados por múltiples motivos. Esta situación deja en evidencia un enquistamiento en la práctica desde su naturalización cultural donde el 
hecho se reduce a una ausencia que, en muchos casos, no se denuncia y se toma como acto voluntario de aquel que decide irse y no estar más en un sitio específico.

En el 2014, por ejemplo, se registraron en Colombia 7262 desapariciones. De ellas se presume que solo 167 fueron determinadas como desaparición forzada y el resto, según el Instituto Nacional de Medicina Legal y Ciencias Forenses, como posibles ausencias voluntarias.

La falta de garantías en la denuncia de la responsabilidad de los gobiernos, en especial de las fuerzas militares en varios de estos, y de la tramitología son algunos de los elementos que problematizan el fenómeno de la desaparición forzada en el país. Sin embargo, el punto más crítico tiene que ver con la falta de justicia, el seguimiento y la reparación, lo cual ha llevado a que las víctimas sean abandonadas y sufran un vejamen adicional al no ser escuchadas y, en algunos casos, reconocidas como tal.

En ese sentido, resulta consecuente que, si el Estado no asume su responsabilidad en este tipo de prácticas, la población colombiana se torna tendenciosa en su lógica de establecer solidaridad con las víctimas. Es por eso que se pasa de la rabia y la conmoción nacional por la ausencia de un jugador de futbol que gana millones de dólares al día en un club y no le permiten jugar un partido, a un mecánico suspiro cuando se habla del tema de la ausencia de personas que no les permiten ni vivir ni morir dignamente; al seguir a Sontag (2004), ajenos ante el dolor de los demás. Tal como lo plantea la misma Schindel (2012), una sociedad debe pensar su responsabilidad cuando, en temas como la desaparición, la indiferencia es un rol protagónico para la efectividad de la práctica, pues «... la desaparición de personas tuvo lugar no a pesar o en contra, sino como consecuencia de lo que esa sociedad era o es $[\ldots]$ sociedad que le dio origen y le brindó sus condiciones de posibilidad» (p. 48).

Apesar de las derivas históricas del tema, de los múltiples antecedentes y de lo inabarcable que resulta estimar el real impacto de lo sucedido en los comportamientos de la sociedad contemporánea, es fundamental 
establecer la necesidad de distinguir tres niveles en la problemática: primero, el marco histórico sociocultural, el cual se alimenta del papel del Estado que genera en el poblador la normalización de un fenómeno anormal para cualquier sociedad «democrática».

Segundo, la responsabilidad política de este mismo ciudadano en la perpetuación de una guerra que se nutre, en buena medida, por la indiferencia social. Tercero, la importancia de que actores académicos establezcan, de forma clara, la distinción de lo que sucede en el país para ayudar a evitar reduccionismos o sincretismos cuando se habla de agentes sociales, responsabilidades y contextos específicos, ya que gran parte de tal insensibilización ante lo sucedido pasa por generalizar una crisis entre malos y buenos donde se habla mucho, pero aún se conoce poco frente a la naturaleza de la violencia política en dicho territorio. 


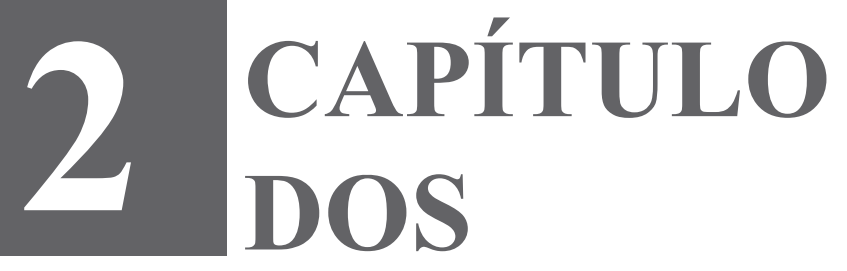




\section{Revisión de contexto, una mirada desviada}

El cuerpo ha sido una dialéctica que transita, como el pais, entre lo bello y lo ominoso, lugar de vejaciones políticas

$y$ de resarcimiento identitario, producción y reproducción, complicidad y pasión, escenario del erotismo, opción para el encuentro, sensualidad y pudor, goce y sanción, evidencia de lo perecedero y de estrategias para la sobrevivencia, pero también ha sido continente y contenido de los potenciales liberadores. He querido decir que en tiempo de apocalipsis, hay una opción: la salvación por el cuerpo (Arboleda, 2009, p. 275).

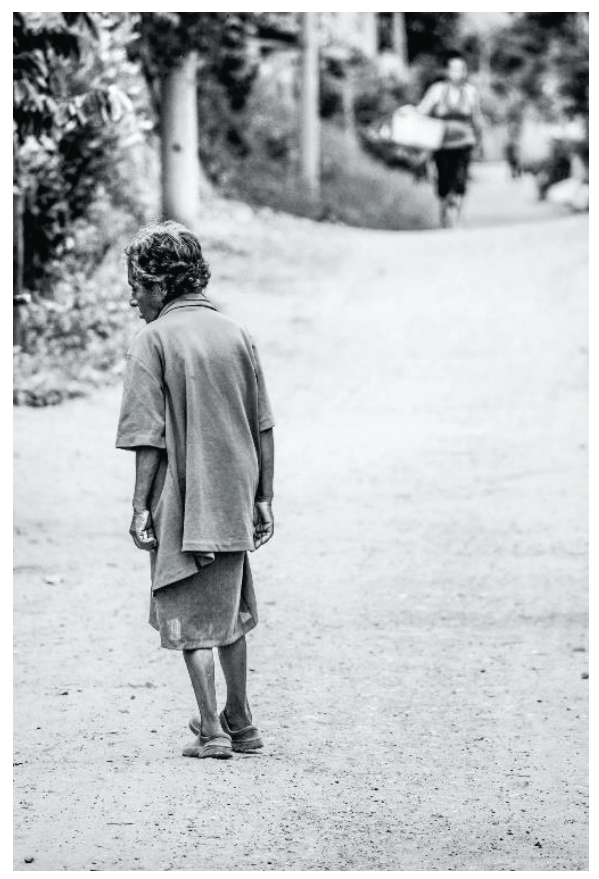

Fotografía por Jhon Hurtado. 
Caminar entre autores, investigaciones e información sobre un tema puntual amplia la mirada, caracteriza el escenario a trabajar, ubica referencias conceptuales, evidencia hallazgos y, finalmente, muestra cuáles campos se han ocupado más de un fenómeno que de otros. Un recorrido contextual deambula entre bases de datos, bibliotecas, grupos de investigación e información dispersa en distintos sitios. Siempre existirán referencias necesarias, pero ausentes, gracias a que la circulación de documentos no implica orden y agrupación sencilla de todo lo producido sobre un tema.

En este apartado se realiza un circuito sobre las referencias bibliográficas que, sobre la desaparición forzada, se ha hecho en Colombia; siempre con el beneficio de la duda para no tomarlo como un estado de arte concluyente, pues la producción no deja de aparecer, pero la circulación no es igualmente efectiva.

Después se hace énfasis en dos casos puntuales desde el abordaje subjetivo y su relación con el duelo, al traer a colación elementos propios del trabajo de campo realizado, los cuales se exponen bajo algunos de los preceptos establecidos en las investigaciones de dos autoras puntuales: Zorio (2011) y Díaz (2008). Estos dialogan entre el trauma de la desaparición forzada de personas y los abordajes que, desde esta experiencia, se pueden problematizar en las elaboraciones.

El imperativo final de este capítulo deja entrever que existe una necesidad de pensar la producción no desde los cuarteles disciplinarios, sino a partir de producciones inter y transdisciplinarias donde dialoguen los distintos campos del saber, desde esquemas más articulados y con resultados más integrales.

\subsection{La desaparición forzada, un camino entre líneas construidas y recorridos por andarse}

La desaparición forzada de personas en Colombia no es un tema ajeno a los intereses académicos de los investigadores de dicho país en los últimos años; aunque es claro que en la revisión documental de los fenómenos sociales más trabajados se encuentran temas de mayor 
abordaje, producción y reflexión como son los de desplazamiento forzado y la violencia entre bandas criminales. En este contexto, la desaparición forzada ha ido ganando relevancia dentro de los intereses temáticos en los últimos veinte años.

En buena medida, Luisa Fernanda Díaz (2011) señala la responsabilidad de este hecho a la agenda discursiva de los medios masivos de comunicación. Tal es el caso abordado por ella sobre el periódico El Tiempo, el cual no solo indica que ha invisibilizado el tema, sino que ha dejado en un lugar ambiguo el papel de la víctima ante la responsabilidad de lo que le ha sucedido.

Además, en el marco de los procesos de violencia política de los años ochenta, dicha autora afirma que la desaparición forzada es un

... hecho de violencia política directa [el cual] se sustenta en otras formas de violencia, [sic] menos visibles y estudiadas, como son la violencia estructural y la simbólica; cada una de las cuales se aborda en su interrelación con las otras para entender la dimensión del crimen (Díaz, 2001, p. 2).

A diferencia del secuestro, el cual ocupa un lugar más visible tanto en el seguimiento como en la denuncia de este en términos históricos y hasta jurídicos, pues su legislación inicial aparece desde finales de 1930 .

Otras aristas ubicadas en relación con el tema, pero focalizadas en otros ángulos, se presentan en investigaciones realizadas como la de Losonczy (2011), en la cual se trabaja el tema de la ritualidad y la muerte desde la santificación del sicario en contextos urbanos; o el caso de Vestri (2015) donde se toma la relación entre la desaparición forzada en términos jurídicos y los falsos positivos como una estructura sistemática articulada desde el Estado.

La cercanía del tema con otros conflictos articulados a la violencia política y social del país implica que el universo de la bibliografía, al ser amplio, tenga focos particulares a la hora de revisar la producción científica en los últimos años. Al tener en cuenta la desaparición 
forzada se halla que la mayoría de la producción referida al caso está trabajada desde lo jurídico, desde la problematización de diversos autores en relación con la jurisprudencia, y desde los mecanismos de tensión-contradicción de la ley y las interpretaciones nacionales e internacionales sobre distintos fallos.

En este sentido, se debe destacar la gran cantidad de material de universidades de tradición en el campo del derecho, tanto en Colombia como en el exterior, que han tomado la responsabilidad académica de abordar la desaparición forzada desde perspectivas sociales y han matizado, en muchos de estos, las deficiencias y las responsabilidades del Estado frente a lo sucedido. Es el caso de Afanador, Cavallo, Citroni, Gonzáles, Monroy, Peña, por mencionar algunos.

En medio de la cuestión, indiscutiblemente gracias a la dinámica de la desaparición forzada de personas en Colombia, uno de los temas que se comportarían como vórtice es el del «cuerpo» y su relación con la «política»; ambos conceptos profusos para las ciencias sociales en general, pero muy desligados el uno del otro a la hora de abordarse en el caso colombiano.

En ese sentido, Blair (2010) teje ambos territorios desde la martirización del cuerpo y el uso excesivo de la violencia, y trata de comprender lo sucedido desde la «economía del castigo» derivada de la «economía del poder»; dos conceptos trabajados en Foucault (2004) desde la biopolítica, pero analizados por la autora en el contexto colombiano, pues como ella misma lo indica, «Pareceríamos estar asistiendo a un escenario de despliegue exacerbado del poder con el fin de fomentar el terror y el miedo sobre la población civil» (Blair, 2010, p. 45), situación donde se destaca como víctima central no el contendiente, sino la población civil inscrita en el medio como un actor más para el perpetrador.

En tal caso, se señala la violence extrême como un dispositivo propio de las guerras contemporáneas, criterio que podría revisarse con base en los mecanismos de tortura aplicados en Colombia en épocas como la llamada «Restauración Conservadora» a finales del siglo XIX 
o la guerra entre liberales y conservadores desde 1940 hasta 1960. La misma Blair destaca que esta definición del término fue propuesta por la etnóloga francesa Véronique Nahoum-Grappe en el marco de la guerra en ex Yugoslavia definiéndolas como «Todas las prácticas de crueldad «exagerada» ejercidas sobre civiles y no sobre el ejército enemigo, que parecen sobrepasar el simple propósito de querer apropiarse de un territorio y de un poder» [Traducción propia] (Nahoum-Grappe, 2002, p. 601).

La potencia del cuerpo es lo que señala Blair (2010) para entender por qué encarnarse con su dolor por parte del victimario. Distingue entre violencia y crueldad donde la primera implica una acción política intencional sobre el contrincante y la segunda se destaca una sevicia que supera la lógica de dicha acción. En palabras de la autora:

¿Por qué sobre los cuerpos? Porque el cuerpo goza de una enorme potencia y una posibilidad inusitada de resistencia que es, finalmente, la que lo hace objetivo del poder [...] esa "lógica perversa" que mueve al poder, al despliegue de toda una mecánica del sufrimiento y el sentido que subyace a cada una de estas formas de violencia, a esas diversas tecnologías corporales para reconstruir - en términos de Foucault - esa economía del castigo (Blair, 2010, p. 45).

El control político sobre el cuerpo, al superar su utilidad física y al ubicar nuevas lógicas de usurpar su lugar real y simbólico, va más allá de un simple acto de guerra y se inscribe también en un deseo de control del victimario que, en el caso de la desaparición forzada, no es solo sobre la vida del otro, sino sobre su muerte; inclusive controla su intermitencia entre lo uno y lo otro, pues tal como lo plantea Díaz (2011), la persona que realiza la desaparición se presenta como un otro sin límites.

Desde otra perspectiva, Sánchez (2011) anuda el inicio del conflicto desde su misma denominación y desde las formas como se nombran los sucesos, los actores y sus relatos más en una urdimbre que, como se viene planteando desde Blair (2010), no es tan simple entenderla desde 
la lógica de la guerra tradicional. Así, volver ajustar la palabra permite entender quienes están en escena, cómo se narran los hechos y cuál es el papel del testimonio para entender la noción de justicia y reparación. En palabras de Sánchez (2011):

Por eso para una visión democrática de la sociedad resulta tan importante la legitimidad y el sentido del disenso, y recuperar el valor de la palabra y de las palabras. No es superfluo el debate sobre cómo nombrar las cosas, los procesos, los lugares. Las batallas que se dan en el lenguaje - lo hemos aprendido claramente en los últimos años - comienzan por los debates sobre cómo nombrar el proceso mismo que vivimos: «guerra», «conflicto», «terrorismo». El lenguaje, como bien sabemos, es una forma de estructuración de la realidad desde determinadas y diferenciadas posiciones sociales, y políticas (p. 73).

La denominación es más que una puesta en escena de la voz de los actores en un territorio, es la caracterización de la noción misma de lo acontecido por cada uno de los miembros. Esta incluye, en ese teatro de la tragedia, al lector, al investigador y al ciudadano que tiene un rol activo desde su aparente distancia social. Siguiendo a Sánchez (2011):

A la luz del contexto de conflicto armado en Colombia y asumiendo que pese a él se está hablando, cabría preguntarse: ¿Está la sociedad en condiciones de escuchar? ¿O están las víctimas en un monólogo revictimizante? Es una pregunta inquietante para todos (p. 73).

La distancia puesto entre el relato del otro y la experiencia vivida con frecuencia saca del lenguaje de la historia, pero, en esa distancia inexistente, se tejen precisamente las responsabilidades políticas.

De esta forma, el sujeto político es un acumulado no solo en el campo de la tragedia vivida por la desaparición forzada, sino en todo el territorio que se dispone para que esto suceda. Continúa Sánchez (2011): 
La voz tiene escenarios y públicos que varían con los momentos políticos y sociales. La víctima y el victimario no hablan solos. A través de ellos hablan relaciones sociales, estructuras de poder, prácticas culturales. El trípode víctima-sociedadvictimario, $[s i c]$ es un trípode dinámico (p. 75).

Y ese dinamismo es el lugar del contexto en el cual no existirían lecturas pasivas.

La muerte tiene su propio relato con múltiples testimonios. Esta es en sí el enunciado, su significante varía dependiendo de la situación y momento. Los trabajos en relación con los trámites de la muerte o la carencia de estos son el punto de anclaje para entender las variables que se juegan en la desaparición forzada.

Distinciones como la de Martínez (2013) respecto a su trabajo de investigación con los habitantes del Cajón, en Catamarca al noroeste de Argentina, permiten establecer las etapas del ritual de muerte en distintos grupos étnicos a partir de la idea del fallecimiento biológico y la defunción social; la primera como el deceso natural y la segunda como el entramado de sentido que la comunidad elabora. En sus palabras:

Las definiciones de los actores sobre la muerte han sido recientemente revisadas. Se ha sugerido que la muerte social ocurre cuando una persona, éste [sic] biológicamente muerta o no, ha dejado de ser tratada por el resto como un agente activo dentro del entramado de relaciones sociales. De acuerdo con esta definición, una persona puede estar socialmente muerta, aunque desde una perspectiva biológica se encuentre viva (Martínez, 2013, p. 2687).

La particularidad de la muerte social implica una relectura de la tesis de Martínez, ya que el desaparecido no tiene un fallecimiento biológico constatable, pues, de tener una muerte social que lo margine, de entrada está excluido, per se, de la interacción social. Este posee una «vida» muy activa gracias a su ausencia; su dificultad con el duelo pasa, precisamente, por el hecho de tener mucha vida en el psiquismo 
del familiar o del ser querido, situación que lo pone en juego con la comunidad, a partir de su deseo de retorno, dado que se le incluye en festejos y se ora para mantenerlo vivo, con el fin de ausentar la muerte como destino.

La acción colectiva registrada en las poblaciones afectadas por la desaparición forzada es una conjugación que, por un lado, intenta reparar la dinámica cotidiana y normalizar el entorno bajo el nuevo lenguaje inscrito, de la violencia a la crueldad; y, por otro, se encuentra bajo el espectro de la ausencia-presencia del otro, un lenguaje inenarrable, el cual se oculta tras la sombra del habitante que padece en silencio su propio combate con la realidad.

La causa del porque el ejercicio antropológico o sociológico no es tan abundante en este campo, en relación al contexto colombiano - proporción menor respecto al mencionado escenario jurídico-, es debido, posiblemente, a que la esencia del relato etnográfico implica la voz, la huella enunciable, el trazo distinguible y el comportamiento comunitario de una población sin dejar ver con facilidad aquello que se escapa, se esconde, se escinde, se reprime o se transforma en la palabra del actor a través de discurso o de sus actos cotidianos.

La interdisciplinariedad y la transdisciplinariedad se vuelven el imperativo académico más importante para este tipo de campos. La producción articulada de distintas miradas disciplinares permite diálogos más estructurados, explicaciones más profundas y propuestas más estables para la investigación e intervención de las poblaciones afectadas por este tema. La revisión de la información muestra infortunadamente lo contrario, pocos trabajos desde estas necesidades de diálogo e investigadores con capacidades de articular desde sus formaciones distintos lugares del saber más allá de una disciplina. No obstante, se registran pocos resultados conjuntos (productos concretos) desde distintos agentes del conocimiento, por lo menos en lo que se refiere al material científico.

De esta forma y posiblemente por esta complejidad del discurso de la víctima y de todos los actores involucrados en general, se encuentra, en el otro ángulo de la revisión para el caso colombiano, una 
bibliografía medianamente amplia y estructurada desde la perspectiva psicológica, la cual hace hincapié con bastante frecuencia en trabajos desde la intervención clínica y la comprensión de los procesos de duelo alrededor de lo acontecido Agudelo y Sánchez (2013), Cardona y Vasco (2013), Díaz (2011), Giraldo (2011), Zorio (2011).

En la mayoría de investigaciones, se da un énfasis desarrollado con base en entrevistas de localización subjetiva o en ejercicios producto del análisis clínico, al cruzar modelos teóricos como el de Sampson, Neimeyer, Pérez y, en especial, desde el andamiaje tópico ofrecido por Freud y Lacan en varios apartados de sus obras, hasta estudios de caso donde se problematizan diferentes categorías de forma comprensiva y ubicadas en un contexto concreto.

Cuando se hace referencia a la desaparición forzada, el tejido roto no se entiende solo por lo agujereado en la experiencia subjetiva y tampoco se puede pensar, exclusivamente, desde un tratamiento en la manifestación social a través de actividades colectivas de reparación. El hilo que se debe anudar es el lazo social y el lugar del sujeto, una comprensión interdisciplinaria que ayude a explicar e intervenir a la población afectada desde dimensiones transdisciplinarias donde la distinción de disciplinas sea clara, pero implique lecturas conjuntas y productos más integrales de todo lo acontecido.

Siendo el ritual y el duelo inexorables para este tipo de sucesos, la perspectiva psicológica posibilita una idea indispensable en la explicación del estado de la cuestión desde una perspectiva amplia. El componente del lugar del relato, enunciado anteriormente por Sánchez (2011), sirve como bisagra para este paso al entendimiento de la subjetivación del agente en el marco de la estructura sociopolítica enunciada.

Agudelo y Sánchez (2013) describen dos formas de afectación psíquica que intervienen en el lugar del discurso de los familiares víctimas, los cuales fueron entrevistados en su investigación a partir de la obra freudiana. Estas son la narcisista y la anaclítica; en la primera, se presenta una identificación-tensión con el objeto amado; mientras que en la segunda, se expresa un sentimiento de protección y 
satisfacción de necesidades, tal como sucede en el modelo de relación con los padres. El resultado del proceso investigativo concluye que, en el caso del vínculo con la desaparición forzada, en el relato de las esposas se distingue un tipo anaclítico y en el de las madres un tipo narcisista. Esta situación la indica el análisis realizado por el grupo de estudio «Psicoanálisis y violencia», de la Universidad Católica de Cali, a partir del caso de una madre que encuentra finalmente los restos de su hijo y, a los pocos días, muere envuelta en una profunda depresión. Este vínculo permite explicar la fuerte devastación que sufre dicha madre.

Homogeneizar el concepto víctima es tan ingenuo como pensar que la responsabilidad reposa solo en un actor. Las anteriores descripciones halladas por Agudelo y Sánchez (2013), coinciden con el planteamiento de Gonzalo Sánchez que se evidenciará en teorías como la de Beverley (1987) y las formas de testimoniar.

Un drama social no es un acontecimiento que se pueda limitar solo desde un cuadrante espacio temporal, la complejidad del relato implica una hermenéutica mayor al tener en cuenta las subjetividades en juego y los catalizadores sociales derivados en palabra, lo cual trae como consecuencia el movimiento del discurso del actor social y, por ende, de los significantes que lo estructuran y definen.

En la realización del trabajo de campo de la investigación, sucesos encontrados en la revisión documental no fueron ajenos a lo vivido, las entrevistas con bastante frecuencia mostraban dos y hasta tres órdenes discursivos presentes en una misma persona. En algunos casos como el de Virginia, víctima que permanece en la población violentada; y el de Iris, la cual se reasento en una ciudad cercana, la naturaleza del discurso cambiaba con asiduidad en la medida que se ubicaban en la narración de cada evento vivido.

Inicialmente, la condición preliminar a la desaparición forzada señaló una situación de precariedad económica con un conformismo, en especial, hacia las necesidades básicas insatisfechas, tal como se evidencia en la siguiente frase: «... no teníamos casi nada, pero eso era suficiente para vivir tranquilos» (Virginia, comunicación personal, julio de 2014). 
Posterior a ello, en el momento de la arremetida de grupos paramilitares en la zona donde se produce la desaparición forzada, durante más o menos dos semanas, el relato adquiere un tono, por supuesto, más dramático, pero por momentos más desafiante. Al seguir con el relato de Virginia ella dice: «... mi esposo trataba de averiguar lo que podía, yo sí fui hasta donde el comandante y le dije que yo sabía que él tenía a mis hijos y que me los tenía que devolver» (Virginia, comunicación personal, 2 de agosto 2014), confrontación que después daría como resultado la huida y el esconderse por un tiempo.

Finalmente, tiempo después de la desaparición, ambas historias en escenarios distintos coincidieron con denotar políticamente su derecho básico de verdad y reparación, y su lugar de víctima, pero desde la dignidad que implica la responsabilidad de hallar justicia para sus seres queridos, tanto así que, por momentos, asumen en las entrevistas ser conscientes de que se encuentran muertos, pero que seguirán exigiendo la verdad y el restablecimiento del buen nombre en honor a ellos y a la justicia que merecen (Irene, comunicación personal, junio de 2013).

El orden del discurso cambia situacionalmente con el vínculo y el territorio que habitan los dolientes, así como con el lugar del ausente-presente, con el cual — de entrada - se puede establecer una relación puntual —en especial de parentesco-, pero donde se nota, con el transcurrir de los años, cómo cambia, tanto en la comprensión y recuerdo del ser perdido, como en el padecimiento que define el estado de angustia en cada momento.

De esta forma, la ecuación social del discurso (D1 económico + D2 político $+\mathrm{D} 3$ social $=$ víctima/subjetividades $)$ permite leer no de manera sincrónica, sino de manera lógica los acumulados del padecimiento y las estrategias para enfrentarlo. No obstante, cada orden del discurso no exime el anterior, por el contrario lo anuda o lo anula a partir de aquello que el relato quiera expresar. Empero, la tipología no puede ser determinista dada la complejidad del enunciado, el contexto y la intención con la cual se emite; puesto que, de igual forma, posibilita denotar la necesidad de ampliar la concepción del otro - víctima, verdugo, desaparecido- - ya que estas tienen aún muchas connotaciones por ser descifradas. 
Como lo plantea Palma (2016) «... en toda memoria hay una dimensión inenarrable, delimitada por los silencios, los olvidos, lo no dicho, y en las memorias sobre la violencia esta dimensión es más marcada» (p. 203). Diálogo aún en construcción que localiza lo que tiene narración, lo que aún no tiene y lo que nunca tendrá, pero que se sustituirá por otro discurso; camino laberíntico por recorrer.

\subsection{Subjetividad, rituales y duelos}

Para el caso colombiano, la subjetividad y las prácticas comunitarias, relacionadas con la desaparición forzada, son dos vetas importantes de tejer desde el proceso de reparación y los medios para llegar a ella. En ese sentido, vale la pena destacar antecedentes, en especial los de Chile y Argentina, donde se encuentra la mayor bibliografia respecto al tema en los últimos años; pues sin ser los únicos países en el hemisferio que abordan el fenómeno, si son quizá los lugares donde más se ha producido literatura para esta discusión a finales del siglo xx.

Desde las primeras lecturas posdictadura en Argentina como es el caso de Gilou Royer de García (1986) sobre la idea de «matar la muerte», en la cual explora el lugar simbólico-subjetivo que allí se teje; pasando por el diálogo entre la memoria y el olvido en el caso chileno con Padilla o el trauma con Brinkmann; hasta lecturas más contemporáneas como la de Careaga sobre los nuevos aportes del psicoanálisis en la comprensión del trauma por la desaparición; la bibliografía no es poca y enriquece el contexto teórico y metodológico del fenómeno, pero el factor comparativo se torna insulso gracias a las particularidades de este drama en Colombia.

Palma (2016), en un artículo al respecto, ubica la desaparición forzada como una verdad caleidoscópica con muchas derivas que se difuminan a la hora de asirla como justicia. Este autor dice:

... el carácter caleidoscópico de la verdad que se puede construir en ese escenario: un escenario sin imágenes, o mejor, con imágenes distorsionadas, sin rostros definidos, solo fragmentos 
visuales y acústicos a partir de los cuales se debe dar sentido a los enunciados de los versionados y tratar de construir la verdad (p. 195).

Al difuminar la verdad se destacan los efectos subjetivos con el trauma, en especial cuando se piensa en la posibilidad de justicia para, posterior a ello, trabajar una elaboración.

La verdad caleidoscópica de Palma (2016) se puede articular con las variables del discurso y sus lugares en la intención enunciativa de una víctima, se marca o se matiza, pero en ambas situaciones se desencadena un lugar como sujeto ante la víctima, ante el verdugo y ante sí mismo.

Zorio, desde la elaboración, también propuso el duelo en la desaparición forzada en Colombia a partir de tres ejes: «... la búsqueda de justicia ubicada en una articulación simbólico-imaginario; la relación ritual-cadáver ubicada en una articulación simbólico-real; y, las construcciones fantasmáticas y los sentimientos de culpa y angustia, ubicados en una articulación real-imaginario» (Zorio como se citó en Ramírez, 2014, p. 117).

Para el primer eje menciona dos tipos de justicia, una divina como castigo de Dios y otra jurídica como castigo a los responsables. De acuerdo a este último, hace insistencia en la verdad del paradero del «cadáver» del desaparecido por encima del castigo mismo. El trabajo de campo realizado no oblitera estas dos demandas, por el contrario, en varias entrevistas son bastante visibles.

Sin embargo, bajo la perspectiva de los movimientos del discurso y su lugar en el deseo de la víctima, se presentan algunos reparos al respecto de este eje, no en cuanto a lo que busca tal justicia, sino frente a los distintos lugares discursivos y, por ende, distintos instrumentos subjetivos que lo recubren.

Uno de ellos tiene que ver con la idea de justicia divina, la cual opera con distintas intenciones al depender del contexto vivido. Para ello, en las entrevistas realizadas y en varias ocasiones, se destacó que 
el primer llamado a dicha justicia tenía que ver con el hecho de que Dios ayudara al regreso vivo del desaparecido; dado que la justicia divina «no abandona». Por eso, después de la inoperancia de las primeras pesquisas judiciales, siempre realizaban misas pidiendo por el retorno vivo. Como ellos mismos lo indicaron: «... se le mandan hacer misas cada año pidiéndole al señor, es como un ritual» (Virginia, comunicación personal, 2 de agosto 2014). Tal petición cambiaba con el lugar psíquico del sujeto ante su realidad. Así, la justicia divina después de un tiempo se convirtió en una mediación para el retorno del individuo, «vivo o muerto, pero saber de él» (Virginia, comunicación personal, 2 de agosto 2014), al abandonar la esperanza en la justicia terrenal y al dejar en Dios la responsabilidad de la aparición.

El paso planteado por Zorio (2011) es de lo simbólico a lo imaginario, pues tal expectativa de justicia es tan solo eso. En el trabajo realizado, este proceso se presenta de otra manera y después de dicha disyuntiva desarrollada por la autora, ya que cambia la naturaleza del discurso $\mathrm{y}$, por ende, su investidura psíquica, de lo imaginario con el fracaso del retorno, a lo simbólico con el papel de reparación o tranquilidad transitoria de la ceremonia religiosa donde la ritualización permanente, de cada año, abre el lugar al abandono de la energía psíquica, la cual es puesta en el regreso del desaparecido y se moviliza hacia la necesidad de la lucha de la justicia jurídica, en especial desde intervenciones internacionales como en el caso de las víctimas de Trujillo, Valle o de la Comunidad de Paz en San José de Apartadó.

En el segundo eje de lo simbólico a lo real, la autora plantea que en la mayoría de las culturas el rito fúnebre ayuda a bordear para empezar a tejer el agujero en lo real, el cual es producto de la pérdida. Para ello, el cadáver es un requisito básico en el éxito de tal proceso, en la desaparición forzada es esta ausencia, esencialmente, el dispositivo político que hace más conflictivo el rol de la víctima y su papel ante la falta. En palabras de Zorio (2011):

En los casos de desaparición forzada, sin el piso simbólico que presta el significante, el agujero en lo real no puede ser bordeado y por tanto el duelo queda irresuelto. Al quedar 
suspendido, el sujeto queda alienado en la pura relación especular imaginaria entre él y el muerto, es decir, una relación mortífera en la que la libido seguirá puesta en el muerto sin poder descargarse y ubicarse en otros objetos y en la vida misma (p. 6)

Para esta condición plantea que el uso de «recursos simbólicos sustitutivos» les ha permitido a algunos familiares emprender una escena ritual conducente en muchos casos a la sustitución del rito mortuorio por medio de otras acciones simbólicas:

Ante la imposibilidad del entierro y de los ritos funerarios creados por la cultura, hallamos que las víctimas emprenden acciones simbólicas que intentan reemplazar los ritos funerarios no realizados. En el caso de misas, construcción de monumentos, altares, entre otros, diversas acciones que realizan en la fecha del cumpleaños del desaparecido o en la fecha de la desaparición. En las entrevistas con familiares de desaparecidos, ellos manifiestan que el apoyo de organizaciones de derechos humanos ha sido importante para la realización de acciones sustitutivas, que intentan honrar la memoria del desaparecido y han tenido, en algunos casos, un carácter reparador en medio del dolor (p. 7).

Este paso de lo simbólico a lo real desarrollado a partir de los hallazgos de la investigadora tiene una inflexión desde la propia investigación realizada. Primero, el recurso simbólico sustitutivo no operó en la información obtenida y trabajada como una alternativa de elaboración del duelo, ya que las personas entrevistadas destacaron la importancia de los rituales colectivos como lo sucedido en el parque cementerio-monumento de Trujillo donde, a través de un ritual, realizaron entierros simbólicos de sus seres queridos. Segundo, se dio importancia a las actividades realizadas en grupos focales por representantes de entidades de atención a víctimas del Estado, con reasentados heridos por este flagelo, en municipios como Pereira en Risaralda. 
En ambos casos, las víctimas reconocieron la utilidad de participar de estos actos, pero insistieron en lo siguiente: «... después de un tiempo uno no puede olvidar, uno no entierra, pues siempre se termina esperando así sea los huesitos de ellos», «... nosotros hacemos el trabajo con ellos, grupos de atención, reuniones, actividades de reparación psicológica, pero el trámite como tal no lo hacen ahí, es más no todos lo hacen y los que lo realizan es después de manera personal» (Psicóloga atención a víctimas Risaralda, comunicación personal, enero 2013).

El ritual colectivo cohesiona parte del tejido social roto y, vía identificación, consigue vínculos nuevos a partir de un dolor compartido. No obstante, la elaboración en el duelo, la cual habla de lo simbólico a lo real para la población con la que se trabajó, es un trámite manifiesto solamente de forma individual.

El discurso social de estos actos posibilita la voz pública de un actor que, inclusive antes de la tragedia, no hacía uso de su derecho ciudadano de participación y exigencia de justicia. Sin embargo, el discurso privado de su dolor no se enuncia, manifiesta y elabora de manera consciente o inconsciente en estas prácticas, pues el drama psíquico obedece a una voz coaccionada por miedos, frustraciones, dolores y angustias personales que si bien se pueden tramitar apoyándose en los actos catárticos públicos, también necesitan un andamiaje que va más allá de estos.

En el caso de acciones sustitutivas encontradas en las entrevistas y en las visitas de campo, muchos de los altares, misas, celebraciones o diarios atravesados por la naturaleza ritual, contrario a lo señalado por Zorio (2011), más que ayudar al trámite o a la despedida del desaparecido, el «descanso de su alma» se convierte en manifestaciones obsesivas que buscan conservar la esperanza de su regreso o la inversión de la energía psíquica en la responsabilidad de la espera.

Magdalena, mamá de un desaparecido en La Sonora, vereda de Trujillo, realizó un cartel enorme donde mostró, con fotos, una cronología de su hijo desde que nació hasta días antes de desaparecer. En la cartelera contó, en primera persona, cada cosa que pasó a su 
alrededor después de la fecha de la desaparición y señaló el profundo deseo de que pronto estuviera de regreso con ella. La familia lo tomó como una reacción normal producto de lo sucedido, pero después, al ver lo profuso de su llanto cada que miraba el cartel y el estado de angustia que le generaba observarlo, decidió buscar ayuda y logró, luego de un tiempo, entregar dicho cartel al museo de la memoria del pueblo. Esta donación le sirvió como una vía de despegue del afecto puesto sobre ese objeto y la necesidad de continuar su vida sin que eso implique el olvido de su hijo, la necesidad de un cambio en ese trauma narcisista de la pérdida.

Úrsula sufrió su perdida paterna cuando aún era niña, su mecanismo de defensa y su deseo la llevó a invertir su energía psíquica en diarios, pues en ellos narraba sus emociones cotidianas de la mano de la esperanza del retorno del padre; cientos de páginas que, al contrario de tramitar, prolongaban la angustia por medio del recurso sustituto de la escritura. Ella decía: «... me quedaba horas en la ventana con la mirada perdida, le escribía lo mucho que lo extrañaba y que quería que volviera pronto y fue así por muchísimo tiempo» (Úrsula, comunicación personal, julio 2015).

La palabra ante la imposibilidad de respuesta, en especial de la madre, fue cambiada por la escritura. Halló en ello mayor libertad para expresarse y manifestar su realidad emocional, así como la conservación simbólica del vínculo con lo perdido y mantener vivo aquello que está en agonía, pues la desaparición acerca más a la expectativa del regreso sin vida del otro - aunque en el discurso se espere lo contrario- y a otorgarle un lugar puntual que no deja al ser amado en la incertidumbre existencial, ni vivo ni muerto. En este recurso, se establecen diálogos en los cuales el enunciado implica pensar que el otro, desde donde se encuentre, escucha la súplica de regreso; la súplica de ese trauma anaclítico que reclama por el abandono.

«Ahora no sé dónde están, los perdí» (Úrsula, comunicación personal, julio 2015). Otra pérdida real y no solo simbólica, la cual no es fortuita, tiene que ver con el propio proceso de duelo de Úrsula, ya que, pasados muchos años, ella pudo tener acceso a las fotos en las 
cuales su padre aparece asesinado. Por eso decía: «... sabía que estaba muerto, pero en ese momento dejé de buscarlo» (Úrsula, comunicación personal, julio 2015); al igual que con Magdalena, el ritual simbólico no permitió elaborar, por el contrario marcó esa tacha de la ausencia donde los objetos (cartel-diarios) se recuerdan, en el orden del discurso, de manera apesadumbrada. La alusión a ellos en las entrevistas es más con desasosiego que con tristeza.

El tercer eje destacado por Zorio (2011) sobre lo real a lo imaginario ubica el tránsito hacia este último cuando no se presenta lo simbólico, lo cual genera una variedad de manifestaciones que no se podrían unificar, ya que el imaginario puede ser más agudo en unos casos que en otros, pues como los entrevistados decían: «... yo he escuchado que él me llama», «... en los sueños pude hablarle, pero en el fondo sabía que estaba soñando», «... mi tía dormía con la camiseta de mi tío y decía que lo sentía ahí todas las noches» (Virginia, comunicación personal, marzo 2012). Este concepto tiene una particularidad que no puede ser tomada como determinante a la hora de configurar la idea de lo imaginario en cada caso, pero que si se inscribe en cualquier situación de la idea de la fantasía. En palabras de Zorio (2011):

A estas construcciones las denominamos construcciones fantasmáticas, porque en ausencia de lo simbólico que permitiría mediar y dar orden a la relación espectral ente el desaparecido y el doliente, surgen fantasías que impulsadas desde lo real, se visten de componentes imaginarios para intentar dar respuesta a la incertidumbre, podríamos decir que hay un tratamiento imaginario de los pendientes entre el muerto y el vivo (p. 8).

La autora cita la experiencia de alguien que busca su hija en cualquier esquina o en los rostros de todo aquel que pueda parecerse. Dicha situación es bastante común en los familiares de los desaparecidos y en las personas entrevistadas el comentario fue semejante, pues decían: «... yo donde llegaba me iba a caminar para ver si por ahí entre la gente podía verlo», «... muchas veces veía personas parecidas y que tenía que ir y reparar bien que no fuera él», 
... un día, estando en Armenia, me bajé en el centro y me puse a pensar en él y de inmediato me puse a buscarlo entre la cara de la gente que transitaba por ahí, como si fuera posible que de repente apareciera entre la multitud, en una ciudad tan distante (Germán, comunicación personal, julio 2014).

El fantasma distancia la cercanía con lo real y se instala en esa búsqueda azarosa de una posibilidad remota de encontrarlo.

A pesar de ello, el hecho de pensar que pueda aparecer en situación de calle - idea común en varios casos - implica un principio de posibilidad-realidad y no solo una entelequia sin base real, ya que esto implicaría que la desaparición no fue forzada, sino voluntaria. En ella se presenta, primero, la existencia viva del otro y, segundo, una alternativa de ayuda o salvación del mismo que, de ser cierta, sería más con la persona que encuentra, la cual descansaría de la búsqueda; y no con el ausente, dado que este decidió irse en un momento determinado.

En el mismo sentido de Zorio (2011), Díaz (2008) realiza una investigación en la cual triangula el dolor, el duelo y la desaparición forzada para establecer las formas de elaboración desde la naturaleza del trauma. Inicialmente caracteriza la desaparición forzada como un ejercicio propio de la modernidad con una intención concreta al decir:

La desaparición forzada es una práctica que busca la exclusión radical del opositor o del extraño; es un procedimiento característico de la época moderna donde hay un intento de normatización de los individuos y las sociedades realizado por medio de la exclusión del otro diferente, es decir, de aquel que se opone a los ideales dominantes. Si bien la exclusión del otro es una práctica que ha subsistido en la relación entre los hombres de todas las épocas, es en la Modernidad donde el avance científico y tecnológico facilita el auge de las prácticas de segregación (p. 3). 
La visibilización del tema de la desaparición forzada de personas durante el siglo xx jugó un papel protagónico en grandes tragedias humanas, tales como la Segunda Guerra Mundial, la guerra civil en Chipre o las dictaduras del Cono Sur. Sin embargo, no se debe omitir el hecho de que tanto la segregación, sucedida con el etnocidio de la conquista de América, como la práctica de la desaparición forzada, en la misma época, constituyen un tapete previo al desarrollo de este dispositivo de sometimiento antes de la Modernidad. Más que se facilitara hacerlo en esta época, la masificación del uso de la desaparición estaba, precisamente, en relación con la impunidad, la cual la ha normalizado desde siglos atrás.

La guerra en Colombia adquiere tal sevicia que, a la hora de trabajar con víctimas, es bastante cuestionable la noción de opositor al ideal dominante o disidente político. Campesinos ausentes por completo de militancia política, niños y hasta bebés han sido objeto de asesinato y desaparición forzada en el país; así, la intención del hecho no se comporta igual que en otros escenarios como las dictaduras.

El mensaje no es sobre el que resiste, sino sobre aquellos que están alrededor; de ahí que, en contextos como el mexicano, el feminicidio o la desaparición de mujeres en manos de grupos narcotraficantes aumentara en los últimos años, pues es atacar al enemigo, pero no desde su cuerpo físico, sino desde su integridad social.

Un caso más reciente lo representan los falsos positivos que, en el escenario colombiano, son la ejecución extrajudicial de jóvenes, los cuales, engañados desde su situación de vulnerabilidad social con promesas laborales, fueron desplazados hasta zonas de conflicto con la insurgencia, luego asesinados y, después, presentados como bajas en combate.

Al respecto, existen varios capturados; entre ellos se incluye un general de la República llamado Henry William Torres, el cual se encuentra en juicio desde agosto de 2016. Campesinos, jóvenes desempleados e inclusive personas como Fair Leonardo Porras, el cual 
fue presentado como líder guerrillero, aunque tenía síndrome de Down, dan cuenta de las particularidades del fenómeno en relación con el tipo de actor social que es habitual en la desaparición forzada.

Posterior a ello, Díaz (2008) desarrolla los avatares del duelo y las posibilidades de este en la desaparición forzada. La tesis central es dada por el lugar de la posible elaboración sin la aparición del cadáver, «... formas posibles de elaborar este duelo, $[\ldots]$ con la ausencia de una prueba material de la muerte del otro» (p. 6), todo esto al interpelar el papel señalado por Freud (1991) sobre la necesidad del principio de realidad para la elaboración del dolor. Destaca la necesidad de diferenciar entre principio de realidad y la prueba de realidad, donde esta última es la evidencia necesaria para que se dispare el direccionamiento psíquico del primer concepto.

En este apartado, Díaz (2008) inicia una primera interpretación, en la cual la prueba de realidad no pasa exclusivamente por la evidencia material del cadáver, sino que puede provenir de un sustituto simbólico. Ella dice: «... podemos proponer que la prueba de realidad que hace que el sujeto inicie el trabajo de duelo no viene de una evidencia material, sino de un movimiento libidinal que tiene su fundamento en la realidad psíquica de un sujeto» (p. 7). Los restos como prueba de realidad no serían entonces, según la autora, condicionantes para la elaboración.

El punto axial de su tesis está en plantear que con la aparición del cadáver no hay garantías para la elaboración, que inclusive al estar presente este, la negación puede ser un proceso normal en la resistencia de un sujeto, el cual, ni con la prueba de realidad, estaría dispuesto a iniciar un trámite que movilice la energía libidinal puesta en el objeto amado. Siguiendo a Díaz (2008):

Así, la muerte o la desaparición del objeto amado no es entonces en sí misma una garantía de que éste [sic] ha dejado de existir para el sujeto, pues ni siquiera ante la presencia de un cadáver el sujeto responde afirmativamente a la exigencia que impone la realidad de separarse del objeto amado. Esto nos enseña 
que en un primer momento el objeto, más que muerto, se ha instaurado psíquicamente como un desaparecido susceptible de reaparecer (p. 8).

La diferencia para el paso al duelo la constituiría entonces «el acto» de renuncia al goce, el cual ata el sujeto al objeto perdido, es decir, es indispensable el movimiento psíquico del sujeto para salir de la melancolía y reinscribir su energía de nuevo.

En pocas de las entrevistas realizadas hubo un retorno efectivo del cadáver, más bien se presentaron muertes posteriores a la desaparición de otros seres queridos; casos en los cuales las ideas de «condena», «fatalidad», «estar pagando penitencia» y «destino ensañado» fueron recurrentes. De esta forma, la formulación de Díaz (2008) adquiere valor, pues en esas situaciones no se dio elaboración de duelo y la melancolía se marcaba, lo cual ubicó un nuevo vínculo entre el desaparecido y el fallecido.

Así, el planteamiento de la autora continúa desde el soporte conceptual en Lacan para pensar en el redireccionamiento de la energía invertida en el ser querido como una alternativa al duelo:

En el seguimiento que hacíamos con Freud sobre la prueba de realidad encontrábamos que no es por la vía de la recuperación del objeto — ni siquiera como cadáver - como el duelo de un sujeto se resuelve. Decíamos, [sic] y encontramos aquí la coincidencia con el planteamiento de Lacan, que es por vía de un cambio en la relación del sujeto con el objeto como este duelo se realiza. La elaboración se da entonces por la vía libidinal y no por el camino del reencuentro o la sustitución del objeto (p. 10).

Los procesos de organización social que aparecen como asociaciones de víctimas en distintos lugares del país defienden el derecho a la justicia, a la verdad y a la reparación; una necesidad primaria producto de ese lazo social roto. En el trabajo de campo realizado, en especial con la Asociación de Familiares de Víctimas de Trujillo (AFAVIT), la 
naturaleza del discurso ubicaba dos escenarios respecto a su rol en la agremiación; por un lado, la vinculación a esta como medio colectivo para exigir derechos y, por otro, el empoderamiento que, como ciudadanos, hicieron al exponerse en espacios públicos, los cuales, antes de la tragedia, jamás hubieran pensado frecuentar.

La formulación de Díaz (2008) obtiene resonancia en aquellos casos donde el ser miembro del colectivo desplaza el esfuerzo enérgico dispuesto a la nostalgia y, estos, asumen dicho escenario como un lugar que permite «movilizar la tristeza», para «no quedarnos quietos llorando», como lo expresa Irene (Comunicación personal, junio de 2013). Si bien no se podría hablar de un duelo elaborado, sí abre una clara ventana para poder llegar a este.

La autora plantea como salida para la elaboración el ritual, la justicia y el acto; como se ha expuesto anteriormente, formas de ingresar, elaborar y concluir el trabajo de duelo. Este proceso tiene como insumo base la posibilidad de concluir sin la presencia efectiva de un cadáver. Ella dice:

Proponemos que la construcción que un doliente haga de un rito, independiente de que la presencia o ausencia de un cadáver pueda facilitar la movilización de su duelo apoyada en el ingreso de un recurso simbólico ante un real innombrable. La realización de un ritual soportado por la comunidad puede permitir a un sujeto apelar al universo simbólico, introducir el logos que en ese momento pareciera revelarse como insuficiente. Creemos que frente a la desaparición forzada de personas, las familias pueden apelar a este recurso buscando en su realización la eficacia simbólica que facilita el desenvolvimiento y el desenlace del conflicto psíquico que la pérdida trae consigo ( $\mathrm{p}$. 13).

Las acciones colectivas permiten eficacia a partir de la legitimidad que el actor da hacia el grupo de personas significante de esta; en este caso, puede ser por medio de las agremiaciones de víctimas con ayuda 
de entidades externas como organizaciones no gubernamentales (ONG) o en la intimidad de la vida familiar, en la cual el tejido se busca sanar al apelar a su parentela. Así continúa Díaz (2008):

La particularidad del rito por la desaparición se encuentra en que cuando un sujeto decide realizar una ceremonia de este tipo es porque ya ha habido una modificación interna a partir de la cual opta por dejar de esperar y asume una nueva posición frente a la pérdida (p. 12).

En este tema, la experiencia de campo no coincide con la tesis planteada, es claro que la presencia real del cadáver, la cual sería el cuerpo del fallecido, no es garantía de elaboración, tanto en familiares de desaparecidos como en cualquier caso donde exista la prueba de realidad. Empero, no fue visible, en ningún testimonio, que la presencia de este no fuera un principio fundamental para el trámite; el cuerpo del difunto y el contacto con este mismo no son indemnidad para establecer el duelo de la víctima, pero su aparición otorga un lugar protagónico en la posibilidad de resolución.

El retorno del cadáver no inscribe una vía per se; requiere de la disposición subjetiva, lo que no implica sistemáticamente que su ausencia, a través de esta disposición, sí lo consiga. Como alude Díaz (2008), se podrían considerar relatos en los cuales esto se logre, pero en el trabajo realizado donde hubo ceremonias de distintos órdenes e intervenciones en varios momentos, esta situación no se presentó con la comunidad.

Cuando se elaboró un duelo, el proceso se produjo gracias a dos circunstancias: por la intervención psicológica individual durante un tiempo prolongado, la cual fue acompañada de actos colectivos de reparación, y cuando hubo retorno o pruebas concretas del cuerpo sin vida del desaparecido.

Úrsula ante la desaparición de su padre intentó, consciente e inconscientemente, hacer un cierre por distintas vías: pasó por varias consultas psicológicas, indagó por la verdad de lo sucedido y usó 
algunos elementos simbólicos para despedirse de su progenitor. No obstante, ninguna de estas alternativas conseguía lo que anhelaba. Después de un tiempo, obtuvo fotos de su padre asesinado, las cuales, al principio, se resistió a verlas; situación que dejaba ver su goce con el deseo puesto en el objeto perdido, pues se encontraba atada a este y a la incertidumbre de años. Aunque existieron testigos cercanos a ella que dieron cuenta del deceso, siempre tomaba las palabras de estos con vacilación e incredulidad, dado que necesitaba la prueba de realidad. Un día la pudo asir las imágenes y con sus palabras expresó: «... descansé, dejé de buscarlo en todas partes y pude iniciar el cierre» (Úrsula, comunicación personal, julio 2014).

No se podría generalizar un ejemplo como este, pero el punto recurrente en todas las entrevistas da cuenta de la utilidad social de la ceremonia, aunque no de su eficacia individual. Contrario a lo señalado por Díaz (2011), la decisión de realizar ritos, en relatos mencionados como el de Magdalena, Úrsula, Iris o Virginia, estaba dirigido a la conservación o el retorno vivo o muerto de su ser querido, pues se ritualizaba la esperanza y, así, se prolongaba el goce y la imposibilidad de salir del duelo.

En el entierro simbólico realizado en el parque cementerio de Trujillo, en el cual participaron algunas de las personas mencionadas, se destaca más el rol de la justicia que de la reparación subjetiva. Frente a ello expresaron: «... enterrábamos objetos de ellos, fue muy duro, pero mi hermana le seguía mandando hacer las misas y hasta que se murió nunca dejo de esperar» (Irene, comunicación personal, agosto 2017). Este tipo de encuentros tienen, en ocasiones, funciones catárticas, pero es en el dispositivo clínico donde esto se puede movilizar hacia otro lugar más allá del dolor expuesto.

Por último, la tesis de Díaz (2008) concluye en la enunciación del papel de la justicia y su eficacia simbólica para asumir el duelo más allá del dolor, situación que al no realizarse trae la prolongación del conflicto debido a la repetición y la no elaboración. Ella expresa: 
Encontramos así que tras los actos más crueles y dolorosos el país sigue su vida diaria sin ninguna modificación, sin un alto en el camino, sin un ritual que ayude a elaborar.

Pero es claro que el olvido producto de la represión, la carencia del ritual y la inoperancia de la justicia se han convertido en nuestro país en elementos favorables a la perpetuación indefinida de la violencia. Podríamos afirmar entonces que la falta de elaboración simbólica de los diversos eventos horrorosos del conflicto social en Colombia, retorna para nuestra sociedad en la forma de múltiples síntomas que van deteriorando cada vez más el vínculo social (p. 13).

El papel reparador de la verdad habla de límites y cierres que no naturalicen el acto violento. Determinar claramente qué sucedió; cuáles fueron los actores, las responsabilidades y corresponsabilidades; y exigir la ubicación de los desaparecidos ofrecería una nueva forma de actuar y de las personas verse ante ellas mismas. Sin lugar a dudas, el reconocimiento del crimen le quita legitimidad al verdugo; lo mueve de su lugar de tirano, en el cual decidió no solo desaparecer un ser querido, sino mantener en cautiverio su paradero; y le devuelve justicia real a la víctima. En este caso, el paso primario en la elaboración no sería una justicia divina que espera la intervención extraterrenal, más que simbólica imaginaria, sino una justicia política que le permite la reparación vía a lo real.

\subsection{Corolario, el ritual de la verdad}

Como toda actividad ritual, la verdad tiene sus propias derivas, ancla responsables y condiciones de afectación de unos sobre otros, determina temporalidad y requiere disposiciones claras para que sea legítima y no solo un enunciado engañoso.

El primer componente de la verdad, cuando se habla de la desaparición forzada, pasa por la idea de lo inenarrable que torna a reconocer el ausente como fallecido, a saber, queda supeditada la posibilidad al capricho del victimario, pues magnificar su posición ante la víctima le da control sobre la vida, la muerte y el desenlace entre 
ambas vías. Primero se pide verdad y después se reclama justicia, pero para esto último lo primordial debe ser el paso básico, es decir, saber del otro y ubicarlo así no sea físicamente, pero sí socialmente a partir de la aceptación del verdugo de haberlo asesinado.

Saberlo muerto es resucitarlo del limbo agónico e iniciar un duelo mediado por los andamiajes del dolor. Uno de ellos es la negación inicial de su partida, es decir, el sentido en el enunciado que habla de aquel que se fue, pues siempre lo incluye de una manera activa, presente, viva y se mitifica su lugar mientras se cierra el duelo, «no hay muerto malo» reza la expresión popular, se le conmuta los errores al fallecido, es amnistiado moralmente y, así, se inicia su partida de la tierra, porque como dicen: «... él está aquí con nosotros, desde arriba nos seguirá protegiendo como lo hizo en vida» (Virginia, comunicación personal, julio de 2014). Barthes, en Crítica y verdad (2004), analiza el tema en relación con la producción cultural, aunque desde otro fenómeno. $\mathrm{Su}$ noción permite entender como el paso del mito en la muerte es una inclusión natural, lo que puede, para el tema de la desaparición forzada, ser útil en la comprensión de futuros trámites.

La muerte: irrealiza la firma del autor y hace de la obra un mito: la verdad de las anécdotas se agota en vano tratando de alcanzar la verdad de los símbolos, Bien lo sabe el sentimiento popular: no vamos a ver representar "una obra de Racine", vamos a ver "a Racine" [...] Y estamos en la verdad, porque nos negamos entonces a que lo muerto se apodere de lo vivo, liberamos a la obra de las sujeciones de la intención, encontramos el temblor mitológico de los sentidos (p. 62).

Así, el camino a la verdad inicia con la certeza de la muerte, la cual requiere mover el lugar del fallecido y mitificar su lugar en lo imaginario para llegar a la construcción de su partida en lo simbólico. El padecimiento producido por la tortura, el cuerpo flagelado y la negación de su existencia social pueden aumentar la dimensión imaginaria del mito del desaparecido, pero, a su vez, esta situación en un tránsito por la verdad del fallecimiento puede ser útil para la construcción de una elaboración. 
La verdad hablaría inicialmente sobre reconocimiento del paradero del desaparecido o de su estado. El victimario tiene dos estructuras discursivas que lo legitiman en el acto, por un lado, dar cuenta de la localización o suerte del desaparecido y, por otro y en relación a este, el carácter de confiabilidad donde, a partir de una acción ritual, reconocería su responsabilidad, se incluiría, se inculparía, testimoniaría su propio crimen y, de esta forma, permitiría que la víctima acepte la verdad como una prueba de realidad irrefutable.

¿Por qué a través de un ritual? La ritualidad del reconocimiento de la verdad es la que garantiza la eficacia simbólica del acto. No basta con un expediente o una confesión ligera, se requiere una escena dispuesta para que el proceso de duelo se dispare en la voz del otro, una solemnidad catártica que posicione el tirano desde su naturaleza de truhan, dado que humanizar su crimen es cultivo para la vía simbólica, situación que aleja la abstracción incierta de lo imaginario.

El país ha tenido una historia del conflicto armado, la cual ha sido sumergida en múltiples disputas, confrontaciones, motivaciones, causas, entre otros. No se podrían equiparar todas las guerras, ni todos los marcos que las definen; la relación entre contendientes no se ha comportado de forma dicotómica, ya que el actor que más ha padecido en todos los tipos de combates ha sido la población civil, poblador inerme que se instrumentaliza para pretender ganar.

Esta misma circunstancia es la que arroja tantas denominaciones en la arqueología del conflicto, de la insurgencia, de los narcotraficantes, de los paramilitares, de los terratenientes y, de manera particular, del Estado con distintas máscaras.

La verdad, en medio de este entorno, implica una decantación circunstancial de los hechos, actores y responsabilidades. Fenómenos como la desaparición forzada requieren un tratamiento cuidadoso a la hora de aceptar la realidad de lo acontecido. No se deben eximir culpas en el nombre de la ley, el sujeto puede tener amnistía en ciertos casos, pero la verdad no. Es indispensable establecer los momentos que caracterizaron lo sucedido y, así, el papel de cada actor allí envuelto, el cual incluye el mismo Estado. 
La escena focal de la verdad, en un ritual público, implica la adaptación del papel de esta y la utilidad en cada momento. Dos ritualidades amparan la verdad en el conflicto colombiano, una desde la aceptación de la culpabilidad puntual de los actores materiales que operaron en un espacio y en un tiempo determinado, y bajo ciertas lógicas funcionales y estructurales, pues para la víctima no solo pasa por quién o qué motivó, intelectualmente, la incursión, sino quién, cómo y por qué la realizó, es decir, darle rostro al causante directo.

Otra desde el reconocimiento de lo acontecido en voz del Estado. Dado que, su omisión, su complicidad, anuencia o ejecución directa -a través de sus representantes - implican darle lugar a quien padece en una dimensión política integral e intenta, con base en esa aceptación, reparar el papel de aquel como un garante legitimo a futuro. Sin este proceso la noción de justicia queda media y se torna inconclusa.

El ritual debe adecuar sus símbolos, significados y sentidos; el medio en el cual se va a desarrollar y lo que se busca a través de este. La verdad no puede escapar de las variables de quien la enuncia y de las implicaciones que eso trae en el universo simbólico de aquel que escucha.

El lunes 26 de septiembre de 2017 en acto público de formalización de los acuerdos de paz entre el Gobierno de Colombia y las Fuerzas Armadas Revolucionarias de Colombia-Ejército del Pueblo (FARCEP), el jefe máximo de esta organización pidió, en medio de la solemnidad de la ceremonia, perdón a las víctimas y por los daños y el dolor causado durante tanto tiempo; acontecimiento que marcó por completo la dinámica ritual. Esta constricción pública se convirtió en el limen ritual de toda la actividad, dado que fue, entre todos los discursos, cánticos, bailes y performancias, el momento de mayor impacto; una inversión de roles y una posibilidad de giro en el estatus social de la víctima donde la eficacia radicó en no intentar justificar de ninguna manera su accionar y en enunciar con vehemencia su responsabilidad en lo sucedido. 
Posteriormente, estos actos se hicieron de nuevo, pero en las poblaciones afectadas por su intervención militar como el caso de Bojayá y la Chinita; allí descubrieron, con la duplicación del acto, una característica propia de este tipo de procesos, en los cuales la distancia con lo efímero se marca en la repetición de todo el proceso ritual.

El Estado, a través del Gobierno nacional, fungió como testigo y juez, no se pronunció, no dio lugar a reconocer su responsabilidad y no se asumió como parte en un momento idóneo para hacerlo. El marco ritual tenía todos los criterios simbólicos para que esa verdad también fuera enunciada por este y no se quedara en una visión aún corta y parcial de lo que ha vivido el país históricamente.

La movilidad que posibilita el rito en la contemporaneidad habla de su validez no de forma estática, pues este, y más un tema con tantas verdades a medias, puede adecuar los símbolos al depender de lo que se busque y del impacto que se quiera tener. Segalen (2005) plantea, en torno a tal maleabilidad simbólica,

Percibir la flexibilidad de los rituales nos lleva a rehabilitar el sentido que les da cada uno de los protagonistas. A fuerza de insistir en los aspectos formales, por definición estables, del ritual, podríamos concluir que los ritos crean sentido para los actores por efecto de la repetición (p. 166).

La reorganización del universo simbólico, ocasionada por una práctica ritual, hace del sentido, que cada participante otorga, una nueva ubicación de los roles y la comprensión cohesionadora de la temporalidad. En el asunto de la verdad se realizan las preguntas ¿qué sucedió? (pasado), ¿quién lo reconoce? (presente) y ¿qué espera? (futuro); este último componente solo se puede proyectar si los anteriores se han resuelto, ya que estos son imprescindibles para la idea de continuar adelante.

Para reparar, se debe cerrar. En este sentido, la verdad es más portadora de justicia que el castigo; noción que adquiere, para el conflicto colombiano, pertinencia, madurez política y obligatoriedad 
plena de todos los responsables. Pensar la verdad, desde escenas rituales, alberga un gran significado, tanto para la justicia como para la elaboración subjetiva; establece en un plano de sentido toda la serie de variables que intervinieron, materiales y simbólicas, y las instrumentaliza una a una; y construye una secuencia que deja testimonio colectivo y graba todo esto en el imaginario social. Tal como lo señala Castillejo (2008),

La verdad, la enunciación de la verdad - en este punto, las asociaciones con la confesión católica o el diván psicoanalítico de cara a la sanación del alma y el espíritu son inevitables-, es presupuesto y condición sine qua non de la reconciliación. Puestas en su conjunto y dinamizadas socialmente, estos cuatro ejes garantizarían la "no repetición" de la violencia o, para ser más preciso, de las "graves violaciones a los derechos humanos", cuyo horizonte moral se cristaliza en el slogan "Nunca jamás", "Never Again" (p. 453).

Como se ha planteado la desaparición forzada de personas en Colombia, esta no es un fenómeno que pueda pensarse desde su punto final, debido a que se sigue presentando en algunas zonas del país. El ejercicio de ritualidad con la verdad contribuiría, fuera de lo ya mencionado, a condicionar los actores y las responsabilidades; a regresar el lugar anómico de la desaparición; a socavar su naturalización y a dejar las personas de frente ante el acontecimiento, es decir, a todos los miembros de la sociedad.

Sistematizar y repetir para agrupar en aquello que Castillejo (2008) denomina «archivos del dolor», fuentes genuinas que contengan el sufrimiento narrado y la verdad plena, al partir por la nominación clara de lo que paso,

Archivar implica nombrar ese pasado, codificarlo por medio de una serie de conceptos y regímenes de clasificación, y unificarlo en un corpus interpretativo. En este sentido, esa relación con él es análoga a la relación que el mapa tiene 
con el territorio. Así, cuando se habla de violencia, el término "reparación" implica hablar de esas operaciones conceptuales que permite dicha posibilidad: "reparación" implica nombrar, codificar y consignar la violencia de una manera muy particular, definirla y así concebir el prospecto de la sanación y, por supuesto, del futuro (p. 470).

La arqueología de la violencia empieza a trazar cartografías por donde han cruzado los escollos del dolor; fuentes de consulta legítimas en la comprensión de la realidad política y en el protocolo de protección para la reparación y la no repetición. En ese sentido, el ritual aún tiene mucho que ofrecer como recurso social, el cual deriva en la construcción de estos archivos. 


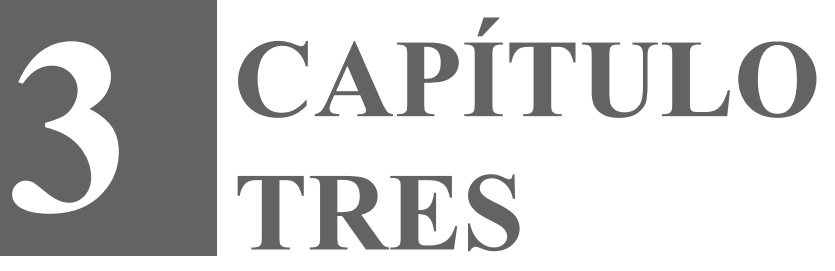




\section{Rituales y cotidianidad, el deseo de la vida $y$ el anhelo a la muerte}

Nuestra vida cambio definitivamente, siempre estamos hablando de ellos, recordándolos, es un ritual mantener siempre presente a los

ausentes

(Familiar de desaparecido en La Sonora, comunicación personal, noviembre de 2015).

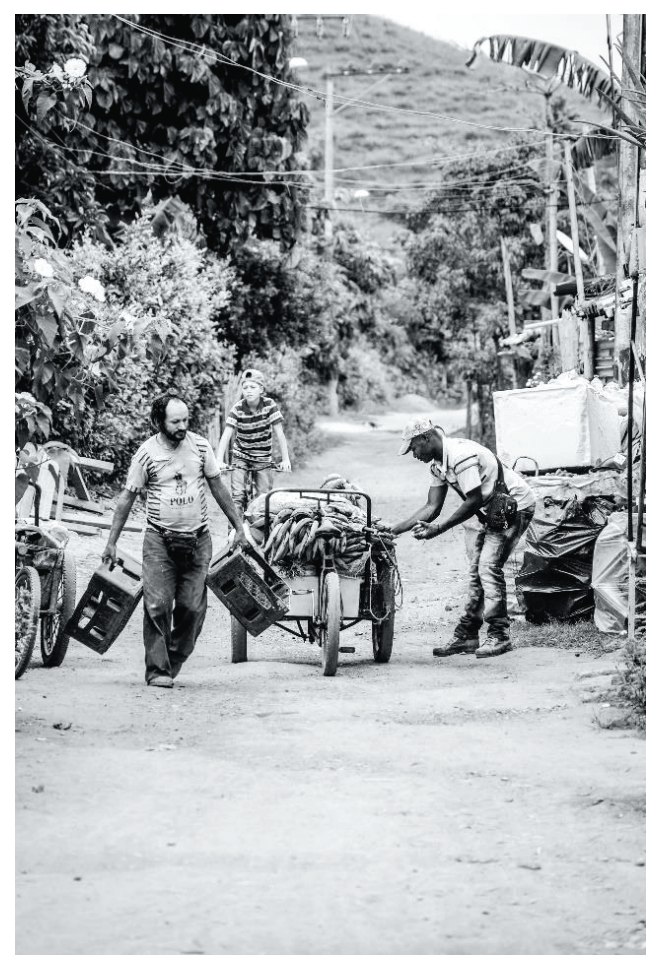

Fotografía por Jhon Hurtado

El ritual es una apuesta de la comunidad y, en ocasiones, se inscribe bajo la estructura política que rige un grupo; por ejemplo, cuando hace alusión al orden, a los roles y a las jerarquías sociales. También 
es marginal a estas intenciones cuando expresa elementos conscientes o inconscientes, los cuales un sujeto utiliza como recurso a través de prácticas que repite cuidadosamente en su entorno.

En ambos casos, el ritual posibilita una relación ambigua de los actores sociales, los cuales, en la escenificación de estas prácticas, realizan movimientos en los roles, así como en las normas y los códigos que establecen lo permitido y lo censurado. La función social es diversa, pero su connotación más representativa tiene que ver con la posibilidad de hacer pública la subjetividad contenida de un actor que sale, por medio de este proceso, de su marco cotidiano.

Este capítulo trabaja las formas del ritual desde varios ángulos y en relación con la desaparición forzada. Primero, distingue las prácticas políticas de ritualizar la ausencia, pues los sujetos disponen de un interés, una voluntad y, ante todo, de una consciencia de lo que procuran realizar y manifiestan en actividades como misas comunitarias, entierros simbólicos o marchas, en las cuales exigen justicia y reparación integral. Son propuestas que empoderan la crisis subjetiva y la dirigen hacia una apropiación política comunitaria.

Segundo, se toma el ritual desde su perspectiva repetitiva y sintomática que lo anuda a la cotidianeidad del objeto "perdido» y esperado; más allá de un deseo de elaboración o una función visible para un trámite de lo sucedido. Es una contención de su melancolía y/o su duelo que, en la mayoría de casos sin resolver, no se tramita si no por medio de prácticas simbólicas que recuerdan el desaparecido de una u otra forma.

En esta sección, se ofrece un soporte conceptual referido al problema abordado, a partir de las definiciones del acto como tal y de la caracterización de este en la sociedad colombiana, tal como se hizo en el capítulo anterior.

Para ello, se ha buscado plantear el ritual en tres denominaciones que marcan las intenciones propias: el ritual de manera explícita, en el cual existe una apuesta social, pública y, ante todo, política; el ritual 
de manera mimética, aquel que termina diluyéndose en las prácticas cotidianas, en las manifestaciones de la espera del ser querido y por medio de ritualizaciones en el día a día que hablan o se expresan en silencio sobre esa persona esperada; y el ritual de manera metafórica, en el cual se pueden articular los dos primeros por medio de apuestas rituales públicas que tratan de una actor individual o individuales, los cuales coinciden con las demandas públicas y colectivas que identifican a las víctimas.

Se continúa con una caracterización general de algunos de esos viejos rituales invocadores del territorio, los cuales se siguen portando, aunque se habite geográficamente lugares de reasentamiento desconocidos para los actores involucrados. Luego se destacan algunos de los nuevos rituales que pueden ser una hibridación de viejas tradiciones con prácticas emergentes o que logran llegar, en algún momento, a ser completamente distintos para esa comunidad reasentada.

Finalmente se trabaja, por un lado, el lugar del recuerdo en el ritual, su función subjetiva y comunitaria y, por otro, el papel de la muerte como búsqueda de satisfacción para reiniciar, por medio de aquello que el psicoanálisis denomina «principio de realidad», el continuar de una vida anclada en la espera.

\subsection{Rituales, funciones y representaciones}

La complejidad del territorio social, político, económico y cultural en las zonas afectadas por la desaparición forzada en Colombia, junto con la condición diversa que la sociedad moderna ofrece a la hora de pensar las manifestaciones públicas y, entre ellas, los rituales como mecanismos de representación social, ubica un número extenso de lugares metodológicos para abordar tales prácticas.

La cantidad de caminos, los cuales trazan las conexiones cercanas que los rituales contienen, identifican diversos fenómenos como son las condiciones económicas, sociales, políticas, culturales, entre otras que se cruzan en prácticas específicas. Así, lo cultural afecta lo político, lo económico cambia las dinámicas sociales, las construcciones políticas desplazan las economías locales, entre otras alteraciones. 
Las prácticas más sencillas en la vida común pueden dar cuenta de la tradición cultural y expresar aquello que un conflicto contemporáneo ha movilizado hacia nuevas representaciones comunitarias.

De esta forma, la interrelación de actores y espacios que se vuelven, en algunos casos, redes infinitas e indispensables a tener en cuenta dentro de una estructura problemática contextual implica hacer obligatorio hincapié en los nodos más representativos que pueden atravesar las manifestaciones sociales, las cuales se desean trabajar.

En las comunidades que han padecido la desaparición forzada, dicha situación implica entender los tejidos que emergen después de lo sucedido, no solamente desde aquello nombrado como orden social, autoridades, jerarquías, roles, entre otros, sino desde las distintas variaciones comunitarias, las cuales se consolidaron al margen de lo estructuralmente visible y dan lugar a elementos que brotan en el marco de un conflicto atemorizador.

Identidad colectiva, enajenación social, aceptación, apropiación, cohesión, resistencia y representación social son efectos que se producen a partir de las dinámicas sociales. Estos se pueden construir, afirmar o rechazar gracias a hechos sociales como ceremonias, conmemoraciones, reuniones, rituales o hábitos, los cuales se cargan de significados para dar un sentido individual o colectivo a su entorno.

De esa manera, tales procesos operan como mediadores tácitos o explícitos, sea para un tránsito emocional o para los imaginarios más diversos que intervienen en la estructura psíquica o en la ideación que, sobre el mundo, tiene una comunidad específica.

Todos estos procesos construyen representaciones sociales, las cuales se mueven a partir de la teoría de Jodelet (1986), específicamente desde la hibridación en la construcción psicológica y cognitiva del sujeto, hacia la definición social y colectiva de una comunidad. En sus palabras dice: «El concepto de representación social designa una forma de conocimiento específico, el saber del sentido común, 
cuyos contenidos manifiestan la operación de procesos generativos y funcionales socialmente caracterizados. En sentido más amplio, designa una forma de pensamiento social» (p. 474).

Para ello, Jodelet (1986) plantea cinco momentos dentro de un sistema triádico compuesto por la objetivización, la significación y la representación social. El primero encarnado en la recepción cognitiva del sujeto, la cual es el espacio primario de la representación, tal cual llega al cerebro y genera una impresión psíquica; el segundo la significación del proceso de representación social donde el sujeto le empieza a dar sentido a esa impresión y le brinda una jerarquía, un anclaje y una orden; el tercero la representación en sí misma que la persona realiza, es decir, la disposición utilizada como recurso para exteriorizar tal abstracción fuera de él; el cuarto la realidad de esa representación, práctica cotidiana, cómo convive y cómo se encuentra con ella misma en la realidad; y el último, la relación intergrupal que allí se genera, pues aquí se dinamiza colectivamente las diferentes propuestas específicas de los sujetos.

Representaciones sociales en el marco de una interrelación que conjuga las disposiciones individuales, reales y cotidianas desde las diversas experiencias, para así construir una conjugación colectiva que, si bien muchas veces no se nombra conscientemente, sí se comparte de tal manera que recrea los imaginarios de forma parecida en ciertas comunidades.

Esta categoría solo es mencionada como punto de partida para entender el impacto de las acciones colectivas en las elaboraciones de la comunidad, cuando dichos comportamientos sociales van más allá de simplemente un encuentro.

Es por eso que, desde lugares cotidianos como los códigos comunes de entendimiento y la motivación de expectativas, hasta las apropiaciones más delirantes del miedo y la frustración, los actores sociales utilizan elementos que se sacralizan o se purifican por medio de acciones colectivas portadoras de sentido. Ningún asunto es exento de la encarnación o la representación que se busca, ni siquiera cuando este ocupa un lugar distante de la escena. 
El ritual como instrumento y categoría conceptual, central en la investigación, posibilitó moverse entre el significado de un grupo específico ante una acción cotidiana y el significante que le otorga un sujeto en un marco social y una experiencia de vida particular. Este es un epicentro de inferencias cotidianas, proposiciones, afirmaciones, tesis y una amplia bibliografía teórica que se ha fortalecido desde años atrás; nociones como las formuladas por Durkheim (1912) o previas a estas como las de Frazer (1994) construyen un camino expedito y bastante profundo frente al tema, el cual se ha focalizado en casos específicos a la hora de abordarse como es el de Gluckmann et al. (1976) que lo hace desde su significación con la violencia; Fortes y la búsqueda de establecer su relación con la magia, tema antes acercado por Frazer al referirse a los ritos simpáticos, animistas, dinamistas y de contagio; y Mauss (1971) y su especificidad hacia el sacrificio y el lugar de la población entre lo sagrado y lo profano. Tema también referido más adelante por Girard (1985), Weber (1984) desde la acción racional y la intencionalidad a partir de la religión protestante, Malinowski desde su papel funcional en un sistema de cosmovisiones que se significan a partir de los usos que las ritualizaciones tienen para distintos aspectos de la vida en comunidad y; así, múltiples autores que si bien lo pueden desarrollan de manera directa como uno de sus objetos de estudio, otros lo hacen de manera secular, es decir, como uno de los componentes que interviene dentro de sus campos estructurales.

En el caso de los dos últimos autores mencionados, el ritual tiene un lugar indispensable en la comprensión del sentido de las comunidades con las cuales han trabajado; no obstante, sus esfuerzos conceptuales no se especifican en este campo temático. Considerar el ritual de esta manera se da gracias a que antes, para muchos, era un elemento específico en un gran universo, pero hoy, con la profundización sufrida en el desarrollo epistemológico, se puede formular como toda una dimensión que compone múltiples universos dentro de sí.

Ejemplo de ello se ve en autores como Douglas (1973) y sus relaciones con la purificación y marginación del proceso; Augé (1998) y los imaginarios que construye el sueño diurno en el ritual; Segalen (2005), el cual propone — en la actualidad — el estudio de 
los rituales contemporáneos en diferentes escenarios como son los partidos de fútbol, los maratones, las fiestas políticas y los matrimonios en comunidades francesas desde 1960 hasta hoy día; o autores antes mencionados como Durkheim (1912) o Mauss (1971) donde, en el caso del primero, este permite una diferenciación de tres tipos de rituales llamándolos «positivos, negativos y piaculares» y, en el caso del segundo, toma los dos primeros, pero hace énfasis significativo en el tránsito de lo sagrado a lo profano del proceso y viceversa, todo ello en el marco de su «eficacia material», en especial desde el sacrificio que este atraviesa, pues dice: «... si se cree en el sacrifico, si es eficaz es en razón de su naturaleza social [...] A nuestro juicio, se entiende por sagrado todo lo que cualifica a la sociedad a juicio del grupo y de sus miembros» (Mauss, 1970, p. 69).

Aunque son muchas las definiciones que existen detrás de estas posturas conceptuales, Segalen (2005) sugiere una que se acerca al análisis teórico a partir de los diferentes autores. Esta expresa: «... el rito se sitúa en definitiva en el acto de creer en su efecto, a través de prácticas de simbolización» (p. 25). A lo que Douglas (1973) llama la imposibilidad de entender las relaciones sociales sin actos simbólicos. En actos de socialización, simples o estructurados, al poner en juego dinámicas simbólicas que dan y prestan sentido a las acciones construidas por el sujeto se evidencia u omite una cadena de significantes sociales.

El ritual asume un rol que coloca en relieve la estructura social desde sus elementos más simples en apariencia. Ejemplo de ello son las normas sociales, hasta sus definiciones más delicadas, como el lenguaje cultural y los símbolos significantes, los cuales van más allá de la palabra y pueden encontrar en esta una resistencia a la manifestación social, para así dar lugar a la resignificación del mensaje y a la interiorización, tanto individual como colectiva, de sentidos que se sedimentan en estructuras más complejas como el cuerpo y sus utilidades positivas y negativas, las cuales emergen de manera consciente e inconsciente en cada sujeto.

La asiduidad que parece tener el tema, en algunos momentos, no es camisa de fuerza que permita hablar de un sistema unificado en cuanto a su función, sentido, significado o intencionalidad social, debido a la 
complejidad que este encierra y a la gran variedad de casos de análisis que dan por sentado un hecho fáctico, pues el contexto es el primer agente mediador para pensar las dinámicas que este envuelve y aún no existe plena aceptación de fenómenos específicos a los cuales se les llama rituales y a los que no cumplen los elementos para entrar en esta categoría. Para algunos autores los episodios de la vida en comunidad cumplen requisitos para entrar en la teoría de la acción ritual; para otros no.

Especial crisis enfrentan las denominaciones modernas bajo las nomenclaturas urbanas no étnicas. En ellas la fragilidad de la denominación de una acción, como parte de un proceso ritual, se descalifica por la ausencia de símbolos o comportamientos que hagan «evidentes» y las diversas cosmovisiones donde la representación, para algunos, debe atravesar los mismos o similares estados que motivaron el estudio de este fenómeno en comunidades indígenas.

Al tener una tradición tan fuerte y ser uno de los ejes primarios de manifestación de cualquier comunidad, el ritual adquiere mayor relevancia si se dimensiona desde la propuesta de Strauss (1984) donde el mito y la celebración ritual ponen de manifiesto las características más intrínsecas de una sociedad, al funcionar como catalizadores de las necesidades más profundas, sean espirituales, instintivas o predeterminadas como ejercicio de liberación. Estas representan el sentido social de una manera menos inaprensibles, pero quizás más sensible a los deseos de los miembros de una comunidad.

En palabras de Turner (1988):

Un ritual es una secuencia estereotipada de actos, que comprende gestos, palabras, objetos, etc. [sic] celebrado en un lugar determinado con el fin de influir en las fuerzas o entidades sobrenaturales en función de los objetivos e intereses de los que lo llevan a cabo - actores del ritual- (p.15).

En una definición más concreta, el ritual desde Turner (1988) permite un diálogo dinámico donde la comunidad deja ver sus tradiciones de manera jerárquica, organizada y estructurada; o de forma 
más efímera y circunstancial, pero al dar, muchas veces, valor a un juego de emotividades y sentimientos que se dejan ver con diferentes sistemas simbólicos y señalan, de esta forma, una semántica entre los participantes del ritual, los símbolos que lo conforman y el significado que este busca, lo cual pone en relieve ese «drama social» que habla desde el fondo de las paradojas y los deseos de un grupo determinado.

Así, el ritual tiene la virtud de no obedecer a lógicas de dominación únicas y puede emerger como resultado de oposición, necesidad o resignificación del espacio. De esta forma, ciertas prácticas se pueden convertir, en la cotidianidad, en un ritual cargado de significaciones - intenciones conscientes o inconscientes - de pequeñas narraciones o expresiones sociales indispensables para la convivencia de un grupo determinado de personas.

Es por ello que el ritual no se puede entender exclusivamente como una práctica ceremonial de una gran puesta en escena o un dispositivo exacerbado y vistoso, sino como una expresión portadora de sentido, con códigos básicos, pero con representaciones complejas de elementos que, a simple vista, son cotidianos y pasajeros.

En palabras de Douglas (1973):

Los ritos sociales crean una realidad que no pueden subsistir sin ellos. No es excesivo decir que el rito significa más para la sociedad que las palabras significan para el pensamiento. Pues es muy posible entrar en conocimiento de algo y hallar luego palabras para ello. Pero es imposible mantener relaciones sociales sin actos simbólicos (p. 89).

Una de las acepciones fundamentales para comprender este fenómeno lo desarrolla Segalen (2005) respecto a los rituales contemporáneos. Esta dice: «... se abre una perspectiva desde la que se perciben como ritos, en la medida en la que ordenan el universo cotidiano, algunos gestos que sin embargo nos parecen ordinarios» (p. 17). Por tal motivo, entre la complejidad y la cotidianidad, se mueven estas disposiciones rituales en un espacio y en un tiempo determinado. 
Previo a la caracterización del ritual en la desaparición forzada, es importante comprender cómo las narrativas sociales, que se construyen alrededor de este, dan cuenta de multiplicidad de relatos, los cuales describen afrentas, tensiones, sublimaciones y confrontaciones que empiezan a brindar al ritual escenarios divergentes $\mathrm{y}$, a su vez, nuevos símbolos que lo componen.

Sin embargo, es fundamental elucidar el cuerpo como uno de esos símbolos que, gracias a su valor, se conserva como eje primario y se ubica con el sujeto, pues el sujeto no tiene cuerpo, el sujeto es cuerpo, primero, en su constitución individual y, luego, desde la ambigüedad del mensaje que este construye como significante en él y en los demás. Un cuerpo que para el ritual es material primario no solo por su representación, sino por su docilidad. En palabras de Foucault (2004), «... al cuerpo que se manipula, al que se da forma, que se educa, que obedece, que responde, que se vuelve hábil o cuyas fuerzas se multiplican» (p. 140).

Sitio íntimo que entra en disposición bajo el limen colectivo que gesta el momento central del ritual, ambivalencia ante la actitud pública que este requiere para que la performancia del proceso no salga de un protocolo simbólico y obligatorio para cargar el sentido y la finalidad misma de este. Roles que implican diseñar el cuerpo previamente y de acuerdo al estatus que se define antes del ritual, pero que en el curso de la finalización va a poner en evidencia esa inversión dramática que en lo físico, lo decorativo o lo comportamental anuncia un nuevo lugar para los actores.

El cuerpo es un ejemplo material del panorama complejo que el ritual teje. La escena es más que la disposición de actores, lenguajes y símbolos en busca de un sentido que puede cohesionar o difuminar al grupo con lo que se quiere expresar en el escenario ritual. Existe un repliegue corporal que se dinamiza desde su forma de abordar el rito no solo con el participante activo del proceso, sino con el cuerpo ausente como portador de un mensaje direccionado al rechazo, al control, al reconocimiento o a la negación según la intención que se busque con la práctica. 


\subsection{La ritualidad en la desaparición forzada}

Lo anterior permite entender cómo en la práctica de las comunidades afectadas por la desaparición forzada se dibujan pequeños rasgos que dan cuenta de elaboraciones, malestares o tan solo síntomas, los cuales deben operar entre el miedo de la repetición del fenómeno, la espera irresuelta de un miembro y el futuro de una comunidad que se reelabora desde el deseo de conservar sus dinámicas más elementales, hasta sus expresiones religiosas, políticas o culturales más trascendentales para la vida anímica del colectivo.

De ahí que no sea fortuita la pregunta por un testimonio, el cual ubique el lugar de los rituales con todo lo que estos disponen, antes del primer caso de desaparición forzada y después del mismo, al establecer la conexión entre la memoria emergente y la apelación al pasado inmediato transfigurado por un acto de violencia extrema. Los rituales vuelven el lugar del testimonio del «otro» al «nosotros» como comunidad.

En medio de posibilidades y referencias que permite el tema del ritual, a mediados del siglo xx autores como el mencionado Turner (1997) y sus momentos de preliminalidad, liminalidad-limen y posliminalidad tomados a su vez de Van (1989), plantean los momentos de separación, margen y agregación, los cuales posibilitan ver un tránsito ritual que ubica los momentos previos-preparativos, desarrollados-consumación en el punto central del rito y posteriores-finalizados.

Se aclara que todo cierre convoca a una apertura de un próximo encuentro, de lo que Turner (1988) llama el «drama social», como toda una disposición grupal que representa la inclusión de lo sagrado en la estructura social con la representación simbólica que esto implica.

Se debe entender la noción de inclusión de lo sagrado como una performancia social y de manera diferente a una hierofanía religiosa o mítica. En el caso de miembros de comunidades afectadas por la desaparición, se pueden dimensionar los alcances trascendentes del contexto cotidiano, por ejemplo, en ciertas imágenes reiterativas 
presentes en sueños o en prendas que evocan al desaparecido y que se introducen en sus prácticas cotidianas, pues estas, muchas veces, se ritualizan al naturalizar el hecho, los significados y los símbolos que encierran.

Cuando las prácticas rituales se colectivizan y adquieren una dinámica, por sencilla que esta sea, se construye lo que Turner (1988) denominó «comunitas», las cuales se definen por un carácter antiestructural dentro del proceso; algo que Sáez (2000) llamaría «inversión de roles» donde el estatus de aquellos que guardan un carácter privilegiado se ve ante la posibilidad de equilibrarse con aquellos que pueden asumirse en un rol nuevo, lo cual les permite elevarse en el lugar de una estructura ya reorganizada por el estado del proceso.

El papel del desaparecido implica, ante la comunidad, perder un derecho ciudadano en cuanto a su condición subjetiva; situación que Kordon (1988) mencionó como doble negación, tanto de vivo como de muerto, y se homogenizó en el lugar común de la víctima con aquellos que, antes del hecho, tenían un rol menos privilegiado en la vida social de la comunidad. Al respecto, puede verse como el primer caso de desaparición forzada registrado en el municipio de Trujillo en el Valle del Cauca en Colombia es el de un sacerdote y su sobrino, quienes meses después aparecieron descuartizados.

Los miembros de la comunidad también habitan el territorio de sus víctimas y pierden distinciones en la forma de testimoniar, ya que van desde una víctima que se reclama, que se espera y que se lucha por ella, hacia una víctima que se reconoce como portadora de sufrimiento, pero no se narra plenamente como tal. El relato es un ritual catártico que exterioriza su dolor y su angustia, siempre con el riesgo de terminar convirtiéndose en una ceremonia cotidiana de su drama.

El ritual asume un rol que coloca en relieve la estructura social desde sus elementos, en apariencia, más simples, por ejemplo las normas sociales y sus definiciones más delicadas como el lenguaje cultural y los símbolos habituales que van más allá de la palabra y pueden identificar en esta una resistencia a la manifestación social, pues dan 
lugar a la resignificación del mensaje y a la interiorización —individual y colectiva - de sentidos que se sedimentan en distribuciones un tanto más complejas, tales como el cuerpo.

La investigación abordó, mediante estrategias de corte etnográfico, las relaciones que se tejen entre los rituales en comunidades afectadas por la desaparición forzada y las prácticas de elaboración, duelo o trámite frente al miembro arrebatado de la comunidad. Esta se llevó a cabo con soporte en los autores mencionados anteriormente e introdujo resignificaciones de los resultados respecto a las categorías

Es importante entender el ritual más allá de una actividad compuesta por símbolos y reglas de forma transitoria o circunstancial, aunque algunos pueden inscribirse en ese sentido. Este es una representación de la realidad social y subjetiva que permite enmascarar, «plastificar», deformar o recordar una experiencia significativa para un colectivo y que, en algún momento, involucra su carácter emotivo en múltiples y variados espacios.

La contemporaneidad ubica a las personas en nuevos escenarios y territorios de ritualidad, en especial al hablar de prácticas que no se limitan a lo religioso o a lo sagrado, pero que aún poseen todas las implicaciones estructurales para una población. Al respecto, Segalen (2005) formula:

Efectivamente, muchas acciones ceremoniales no se adscriben a un pensamiento religioso o a una relación inmanente con lo sagrado, pero a causa de las pulsiones emotivas que ponen en funcionamiento, a causa de las formas morfológicas que revisten y de su capacidad para simbolizar, se consideran rituales, con todos los efectos que ello conlleva (p. 101).

En el caso investigado, los rituales revisten tres posibles derivas para la lógica de un sujeto o una comunidad. La primera, función explícita, cuando el acto que este envuelve es completamente transparente en relación con lo que busca; son ritos de paso (Van, 1989) que ponen en escena cada símbolo con una intención clara de lo pretendido. 
La segunda, función mimética, en la cual se puede presentar un doble sentido entre lo permisivo y lo restrictivo. Esta establece un orden y mimetiza la intención real de lo buscado; sea con el colectivo que lo desarrolló o con la comunidad que lo atestigua.

Esta imitación puede ser exagerada o aproximada a una escena del comportamiento comunitario. En ese doble sentido, se traza una línea entre lo que puede ser realizado y lo que debe ser castigado, pues la función social de un ritual dramatizado, teatralizado y enmascarado (Freud, 1991) no es tan solo una caricaturización, sino todo un código del orden social.

La tercera, función metafórica, aunque se podría decir que la mayoría de los ritos son del orden metafórico, estos, de manera puntual, hacen alusión a deseos o representaciones contenidas en un sujeto o un colectivo, los cuales requieren del uso de la ritualidad para acercarse, consciente o inconscientemente, a través del registro de lo simbólico a ese objeto de deseo.

$\mathrm{Al}$ respecto, en la presente investigación y en torno a la desaparición forzada, es evidente que se continúa buscando, por medio de símbolos, una razón que mantenga vivo aquello que por ninguna vía se le permite «morir».

Estas funciones que brinda el ritual dan cuenta de una cultura que se encarga de proveer instrumentos colectivos e individuales para la intención de una cohesión social; para la apropiación real de dicha cohesión, es decir, el empoderamiento del tejido social; o para la oposición y resistencia que se puede generar ante la idea de la adhesión de un sujeto a un colectivo o de un colectivo a una comunidad mayor.

Una resistencia en la idea comunitaria de cohesión social en zonas afectadas por violencia política se puede ver en el miedo a identificarse como miembros de un mismo territorio, ya que los actores sociales al interior de este empiezan a hacer una distinción de roles entre víctimas directas, involucrados, afectados, inocentes, cómplices y culpables. Un variado número de categorías profundizan una crisis donde el enemigo 
no solo viene de afuera, sino que habita el interior del pueblo y, peor aún, puede terminar instalándose en la cabeza de cada actor, pues como dicen: «aquí todos son sospechosos, ya nadie confía en nadie» (Germán, comunicación personal, noviembre de 2014).

Esta situación sucede en la comunidad de Trujillo en el Valle del Cauca, la cual, después de ser víctima de la desaparición forzada de personas de manera sistemática y aún inacabada desde finales de los años ochenta, traza diferencias entre los familiares de las víctimas; los que se involucraron con medios de resistencia, tales como una asociación; y los que, como lo narra un miembro de este pueblo, «... no tenemos nada que ver con eso, pero igual nos vimos afectados por esa gente» (Germán, comunicación personal, noviembre de 2014). Tensiones que particularizan la idea de víctima, en múltiples niveles y hacen de la justicia una diáspora de difícil compresión.

La división social implica una cartografía llena de quiebres y un mapa de un territorio codificado por cuadrantes espaciales delimitados, pero con significantes comunitarios amplios. La conocida y reclamada voz de la comunidad es polifónica y los testigos-testimoniantes no pueden ubicarse en una sola posición. Respecto al testimonio, Estrada (2013) expresa:

Rescata la dignidad de aquellos que la perdieron de forma violenta. Se recuperan emociones, experiencias y sensaciones de las que se hace partícipe al oyente, al espectador, al visitante al museo. Las víctimas no son las cifras que normalmente forman parte del discurso historiográfico, porque ahora sus rostros irrumpen, no solo para que conozcamos qué pasó, sino, lo que es más importante, para que compartamos su dolor ( $\mathrm{p}$. $85)$.

En lo trabajado por Estrada (2013), la narración implica la fuente única - víctimas - y su lugar ante un conflicto; sin embargo, en el contexto mencionado, la noción de víctima no se podría limitar a una sola sin tener en cuenta la relacionalidad de los actores ante el acontecimiento traumático $\mathrm{y}$, de igual manera, su toma de posición 
como mecanismo de supervivencia para aquellos que permanecen en el territorio afectado o de protección para los reasentados en nuevas comunidades.

Aquí, la cohesión depende de la relacionalidad del actor con el territorio y las nuevas formas de vinculación con nuevas comunidades. Se da el paso de la unión a la adhesión como mecanismo preliminar antes de buscar identificaciones con esos lugares de recepción, como se mencionó anteriormente una intención de vínculo a la comunidad, pero con distintos desenlaces cuando, dentro de una misma experiencia, subyacen diferentes miradas.

Los procesos de ritualidad que permiten una apropiación y empoderamiento, en pos de la recuperación del tejido social, se materializan de manera particular en comunidades que han podido resistir de forma colectiva y han intentado elaborar un duelo o un corte ante la pérdida o el padecimiento recibido.

Este es el ejemplo de lo sucedido en la desaparición de sesenta personas y la masacre de casi un centenar de pobladores en el Alto Naya-Cauca en el año 2001, territorio de fuerte influencia indígena donde la conocida «masacre del Naya» permitió, después de mucho sufrimiento, en especial por parte de las mujeres, intentar reconstruir - poco a poco-, su base social y resignificar su noción de identidad. En palabras de una habitante de la zona:

Nosotras casi la mayoría, pues no sabía si era india, si era gringa o si era campesina o qué era. Al organizarme me di cuenta que yo era indígena. Claro yo pienso que sí, porque nosotras las mujeres tenemos más la capacidad de asimilar, como de superar los problemas, porque ya sabemos que nosotras somos capaces de tener un hijo, ahora cómo no vamos a ser capaces de superar problemas (Úrsula, comunicación personal, julio 2013).

No solo la organización y el lugar de la elaboración de diversos rituales de función explícita que reclaman justicia y reparación les permite empoderar su noción étnica y, a su vez, su condición de género. 
De esta manera, el rol social les corresponde más allá de simplificarlo todo en la noción de mujeres víctimas.

El ritual, como medio de oposición y/o resistencia ante un colectivo $\mathrm{y}$ ante un sistema ordenado de normas y roles comunitarios, se presenta de múltiples formas, pero tiene particular significado en las comunidades reasentadas, las cuales - muchas de ellas — se resisten a perder valores tradicionales propios y demandan, por medio de actos colectivos, el reconocimiento y la posibilidad de expresar aquello que les pertenece por encima del lugar al que llegan.

Por un lado, la visibilización de su territorio y de la cultura más allá del espacio que habitan y, por otro, su dolor ante un drama que continúa en la impunidad. Al respecto, en una entrevista realizada a un miembro de una comunidad reasentada, el cual era proveniente del Tolima, se expresa lo siguiente: «... el gobierno promete, pero no cumple, sin embargo nosotros no dejamos de movernos» (Germán, comunicación personal, 2014). Buscar visibilizar su tragedia es mantener viva, en cada acto, la responsabilidad inconclusa del Estado.

Llorar en medio de bailes nocturnos y al ritmo de tambores en medio de grandes urbes es un ejemplo de comunidades reasentadas provenientes del Chocó, las cuales conservan una tradición y, además, denuncian, exorcizan y, ante todo, expresan la oposición al Gobierno por medio del ritual que busca alterar un sistema de ordenamiento social preestablecido.

El rito o ritual es un conjunto de actos formalizados, expresivos, portadores de una dimensión simbólica. El rito se caracteriza por una configuración espacio-temporal específica, por el recurso a una serie de objetos, por unos sistemas de comportamiento y de lenguaje específicos, y por unos signos emblemáticos, cuyo sentido codificado constituye uno de los bienes comunes de un grupo (Segalen, 2005, p. 30).

Estas funciones del ritual se hacen más complejas cuando se abordan otros elementos simbólicos y de relevancia en toda la estructura y efectividad de este. Esta situación sucede con el rol y la responsabilidad 
de quienes asumen prácticas que denuncian o recuerdan lo acaecido, pues la ineficacia del Estado en la protección de las comunidades implica actores denunciantes de su tragedia y, a su vez, testimoniantes del episodio perpetrado. Una doble condición de víctima y testigo «privilegiado» del crimen; condición desarrollada en la metodología de esta investigación.

De esta forma, la comunidad también hace del testimonio un ritual y busca, con ello, materializar la denuncia o el desafío de no olvidar a las personas, sea desde el rol de familiares o de pobladores, con sus acepciones amplias; y hacer de su práctica una misma colectividad cohesionada por el reclamo. Es por eso que se ven manifestaciones de pueblos enteros, los cuales marchan por sus derechos básicos arrebatados y los de sus seres queridos; ejemplo de los miles de casos que se presentan en Colombia:

Comunidad de Paz de San José de Apartadó pide justicia. En una audiencia pública, los integrantes de la Comunidad de Paz de San José de Apartadó narraron sus dramáticos testimonios cuando, en 2005, varios de sus habitantes fueron masacrados. Continúan en la búsqueda de justicia y denuncian persecución (Semana, 2010, s. p.).

$1.453[\mathrm{sic}]$ víctimas de desaparición forzada piden justicia en Santander. Las víctimas de desaparición forzada en el departamento salieron a las calles del área metropolitana para exigir seriedad en los procesos en el marco del Día Internacional del Detenido Desaparecido, [sic] que se conmemora este domingo 30 de agosto (Noticias de Santander, 2015, s. p.).

Marchar, ante los ojos de los demás, es visibilizar una causa, un rostro, un retrato que se niega a quedar en el olvido y un ritual que se prepara desde la mañana: la ropa cómoda, los zapatos y el objeto que, preferiblemente, se pueda portar en el trayecto de la movilización. Las personas buscan ampliar la imagen, pegarla en un recuadro y llorar un poco antes de llenarse de valor para caminar recorridos extensos, gritar de nuevo y a viva voz el nombre de quien ya no está, en el asfalto enunciar el ausente y demandar justicia por lo ocurrido. 
Se grita, se llama y se busca. En palabras de una de las víctimas con la que se trabajó, esta decía: «... en ocasiones en la multitud lo busco, me parece que en cualquier momento va aparecer con la ropa sucia, en medio de la nada» (Úrsula, comunicación personal, julio 2013), es decir, se llora, se «camina» la tristeza y se espera que el despuntar de la tarde traiga consigo el cansancio y la satisfacción de que el sujeto desaparecido aún está presente y de que ahora, más que nunca, no está muerto, sino que salió a participar de la marcha con todos ellos.

Los familiares se vuelven personas públicas y, consecuentemente, su vida privada salta a la calle, un método de catarsis y, además, de resistencia al olvido de los desaparecidos, un mecanismo que puede garantizar que los ojos enfocados en un grupo vulnerado frenen la posible repetición de los hechos o, al contrario, la agudicen por aquellos que quieren mantener la desaparición en la impunidad.

\subsection{Viejos rituales}

Caracterizar de manera general el ritual y, dentro de este, aquellos que hacen alusión a la muerte, a la ausencia o a la desaparición, implica pensar que el carácter de los mismos, históricamente, se ha establecido desde muchas prácticas y con múltiples significados. Sin embargo, para la investigación desarrollada, los actores, con los que se trabajó, mencionaron con insistencia la idea inicial respecto a este tipo de rituales desde el campo religioso.

Después de trabajar con ellos dicha noción cambió y se inscribió en representaciones sociales más amplias. Es importante tener en cuenta cómo la palabra dentro del imaginario de ciertos grupos poblacionales se adhiere a nociones más trascendentales del campo de la espiritualidad, gracias a la fuerte influencia de un Estado social de derecho, el cual fue intervenido históricamente desde la religiosidad católica. Por eso, la respuesta más común de las personas, ante su interpretación de la palabra ritual, fue la religión o la forma de asumir la muerte desde esta:

... ritual es como un ejercicio que se hace de acontecimientos y de cosas vividas. Uno como que asocia eso a la religión: acá era un pueblo trabajador, campesino, ocupado en sus tierras 
y lógicamente en sus mercados los días sábados y las fiestas religiosas que entonces tenían más auge en la parte católica (Irene, comunicación persona, marzo 2013).

«... se traía un cajoncito, un ritual y acá en los osarios se decía que acá era sepultada la persona desaparecida» (Virginia, comunicación personal, julio 2014).

¿Y qué es ritual?, ritual se me viene a mí a la cabeza como cuando uno hace una semejanza de una persona que se muere. Eso es un ritual. Entonces uno hace como que esa persona la estuviera uno velando. Normales, católicos o evangélicos, pero normales, con entierro (Germán, comunicación personal, marzo 2013).

En otros casos se asociaba la ritualidad con el opuesto católico según la tradición religiosa, pues decían: «... ritual: no, pues para mí, significaría como si pertenece a alguna secta o me llama la atención es por el tema de satanismo» (Virginia, comunicación personal, julio 2014). En cualquier caso, estas significaciones iniciales distan mucho de la comprensión posterior del ritual como práctica de sentido cotidiano; no limitado a lo religioso.

Inicialmente y de manera más genérica, se debe ubicar el ritual desde una dimensión geográfica, ya que este no solo representa una práctica, sino que denomina un ser social y su identificación con un territorio específico.

En comunidades de arraigo agrícola o campesino, la denominación así lo marca «... somos gente de campo, ese es nuestro lugar» (Virginia, comunicación personal, julio 2014); mientras en comunidades de asentamientos ribereños, como el caso de algunas comunidades indígenas embera en Colombia, su forma de nombrarse es distinta, pues dicen «... nosotros somos gente de río, de allí venimos» (Germán, comunicación personal, marzo 2013). Estas expresiones varían en cada contexto, en especial porque marcan la relación supervivenciaidentidad y cultura. 
Sin embargo, en el caso de las poblaciones reasentadas y afectadas por la violencia, en especial jóvenes y niños terminan siendo cooptados por la resignificación del espacio urbano al cual llegan; a diferencia de personas más adultas que han tenido mayor convivencia con su espacio tradicional, lo cual les permite una noción de arraigo territorial de donde vienen y una condición de visitante forzado de la ciudad a la cual migraron.

Algunas zonas rurales afectadas por la desaparición y el desplazamiento forzado, las cuales son proveedoras permanentes de comunidades reasentadas, tienen como característica la influencia en las prácticas sociales de las cabeceras municipales, lo cual favorece la existencia de un actor mediado por su arraigo territorial, sus costumbres y sus hábitos desde su vínculo con la tierra. No obstante, este es atravesado fuertemente por las prácticas rituales propias de la ciudad, de ahí la relación entre la injerencia católica, común en dinámicas urbanas, y las tradiciones, en especial campesinas, tal como lo señala una de las personas entrevistadas:

Antes de que sucedieran los casos, andábamos siempre en grupos de oración visitando las familias. Se organizaba la navidad, compartir la natilla, compartir con los vecinos, eran momentos muy felices para nosotros en el campo. Las festividades todas las compartíamos en familia. También la Semana Santa. Siempre permanecer muy unidos. En ese tiempo había mucha alegría, a pesar de que había mucha abundancia de plátano, de café, pero siempre había necesidades. Pero manteníamos alegres: habían peleas de gallos, fútbol, torneos de microfútbol. Muchos de ellos desaparecieron (Virginia, comunicación personal, julio 2014).

Esta combinación de tradiciones da como resultado la aparición de muchas prácticas o el sincretismo de algunas de ellas, las cuales, en términos generales, son la influencia en buena parte de la población colombiana, sin desconocer el carácter pluriétnico y multicultural del país. 
Este es el caso de varias comunidades ubicadas en los departamentos de Chocó y Nariño donde el contexto marca pautas con sus rituales, por ejemplo, una de las personas con las que se trabajó en la investigación recordaba su lugar de origen respecto a La Lunada, el cual es un ritual tradicional que hacía parte de su historia como una práctica mística donde el medio ambiente jugaba un rol significativo. Ella decía: «en las lunadas [...] la luna es tan fuerte que es la que alumbra las calles» (Úrsula, comunicación personal, julio de 2013).

La preparación del escenario para el ritual es una disposición de elementos compuesta por clarinetes, requintas y tambores. El actor central, quien marca los ritmos de la noche es

... un señor que era como el que sabía más de música del pacífico que es la chirimía, él era la persona más capacitada, iba por todas las casas, por ahí a las cinco de la mañana antes de que amaneciera tocando las puertas y tocando la chirimía con el clarinete y la requinta (Úrsula, comunicación personal, julio 2013).

La comunidad va saliendo e integrándose en un enorme baile lleno de movimiento y de canto, la iluminación de la luna en la noche implica tener las luces apagadas y el día previo se carga de expectativa antes de dormir. Ahí la preliminalidad entra en escena y espera la consumación inicial o liminalidad cuando alguien toca la puerta con fuerza y con sonidos, al fondo de la calle, el baile y el licor artesanal llevan al limen o punto de excitación más elevado; expresión consumada por la aceleración del ritmo y la intensidad del baile. Se procura llegar a este estado - limen — antes de que salga el sol. La lunada empieza a caer con los últimos destellos de la noche como inspiradora, protectora $\mathrm{y}$, muy significativamente, como cómplice de aquello que no se puede ver-hacer en el día; el sol es el reestablecimiento del orden, la posliminalidad.

Este mismo ritual, posterior a los ataques padecidos por la desaparición forzada, tuvo como elemento primario la luz y su ausencia, ya que esta se comportó como copartícipe de los acontecimientos de 
violencia padecidos por dichas comunidades. Su rol se invierte, antes era evitada como parte del ritual de la liberación y la permisividad nocturna, después de estos sucesos se convirtió en la garantía de no perder de vista todo aquello que los rodea y puede ser arrebatado por las sombras que acechan el territorio en la oscuridad.

Como se ha mencionado, la variedad de rituales que tiene una comunidad puede dar cuenta de estructuras profundas de una dinámica social o prácticas ritualizadas cotidianas, las cuales dejan ver algo de la función de un hábito específico. Para el caso de la desaparición forzada, es indiscutible hacer una mención a los rituales previos al acontecimiento, pues estos dan cuenta de cómo se ha representado la muerte y los símbolos que se elaboran alrededor de la misma.

La manera como se ritualiza o sacraliza la muerte es culturalmente múltiple y varía en contextos y situaciones específicas, pero, en el fondo, lo simbólico de estos rituales siempre anuda el vacío que va de lo real de la ausencia a lo imaginario de un faltante que se debe reconfigurar, es decir, permite un trámite vía a la elaboración.

Los rituales pueden oscilar, por un lado, entre el llanto intermitente, profuso y reprimido; por otro lado, desde el grito, el canto y el baile para así celebrar la partida con música, tal como sucede en varias comunidades en el pacífico colombiano; o padecer con abnegación el sufrimiento. En comunidades de tradición católica se demuestra que, independiente de la tradición, la muerte no se tramita de cualquier forma y que los muertos no se van sin un proceso que los despida.

Velando o bailando, el cuerpo es el símbolo primario de estos rituales, es el espíritu que anima la partida y que debe efectuar una preparación física, con prendas y maquillaje, que de una connotación más viva del difunto. Agenciar el proceso inicia con la preparación del muerto y de aquellos que hacen parte de la dinámica; vestirse de ciertos colores es establecer una distinción que dé cuenta del estado social que se empieza a vivir, una especie de marca pública que implica compartir la tristeza. 
Acompañar al fallecido es llorarlo, mirarlo, llamarlo con insistencia, ver que está ahí, pero, verificar que ya no está vivo. Acercarse al cuerpo durante el proceso es poder despedirse de varias maneras con un suspiro, unas palabras o un profundo silencio que se irrumpe por oraciones o por cánticos. Dependiendo del contexto se dejan pasar las horas, pues cerrar la primera parte del duelo es reconocer el símbolo del proceso ritual como una estrategia para la elaboración, es «saber despedirse y dejarlo ir».

Este primer esbozo de los diferentes rituales de muerte confirma que, en el caso de culturas con tradiciones diversas, el ritual es vital en la elaboración y el cuerpo, dentro de este, es el símbolo que permite constatar el proceso entre lo imaginario y lo real.

No es posible caracterizar algunos de los rituales con los que la comunidad migra sin hacer una pequeña alusión al ritual más importante en relación con la investigación, el cual es precisamente el ritual de muerte donde las prácticas y los símbolos son diversos y dependen de contextos, pero el papel que cumplen es fundamental en la dinámica de elaboración de un grupo social determinado.

Al interpelar a la población con la cual se trabajó, el porcentaje mayoritario de esta sintetizó el tema al plantear que el ritual de muerte en las cabeceras de los municipios es generalmente el mismo que se realiza en la ciudad receptora, ya que la influencia hace parte del mismo marco social, es decir, desde la religiosidad católica, el velorio, la misa, el recorrido hasta el cementerio y, finalmente, el entierro.

El proceso previo es más íntimo, pues solo compete a la familia, esto es, la preparación de cada uno de los miembros en sus casas como llorar en ocasiones, nombrar el difunto y mirar asiduamente el símbolo que está contenido en sus objetos personales. Este inicio del ritual se configura y se define de igual manera en el cierre, dado que el trámite de clausura implica el regreso al hogar en la misma dinámica de intimidad parecida, espacialmente, al inicio del ritual, pero con un efecto simbólico distinto donde se avanza en el trabajo de duelo. 
El salto de lo privado a la escena pública se da en la velación, en la liturgia, en la caravana de acompañamiento y en el entierro. Los símbolos más recurrentes en estos espacios son: el uso de color negro que da la impronta lúgubre y el comportamiento que marca una pauta en la dinámica ritual con fuertes rasgos de solemnidad en cada acto, la cual se ve cortada, eventualmente, con las crisis episódicas que sufren los familiares.

Velar el cuerpo en una sala si bien remarca el sufrimiento del familiar al martirizar su tristeza, en algunos casos permite crisis controladas de melancolía que pueden convertirse en momentos catárticos, los cuales ayudan al proceso posterior de duelo.

La despedida inicial la destaca el sacerdote que preside la misa. Este enfatiza en el nombre del muerto, el cual se repite varias veces durante la ceremonia y se escribe en un listón para recordar públicamente quién se aleja de la comunidad. Posterior a ello, el recorrido final se lleva a cabo en extensas caravanas que acompañan su último trayecto hasta donde «descansará en su última morada».

Todo esto se articula al entorno físico: las prendas oscuras como respeto al fallecido, los arreglos florales con diversos colores como solidaridad a los familiares y el silencio social en todo el proceso ritual como pauta de comportamiento colectivo. Por último, se otorga licencia comunitaria para las lágrimas y las abstracciones continuas de los más allegados, lo cual tiene su punto más álgido en el momento del entierro.

Geográficamente, por la misma costa pacífica en Tumaco-Nariño, de donde es otro de los actores que ayudaron con la investigación, una comunidad ritualiza su experiencia con la muerte al hacer hincapié en el baile:

Ellos hacen unas cosas que llaman: los alabados, las alabanzas, y van con el muerto cantando. Ellos no lo hacen tanto por llanto, aunque también hay personas que lo hacen con llanto que son las plañideras, pero la mayoría se desahoga es con el 
canto, unos cantos muy hermosos que son inventados por los propios afrocolombianos (Úrsula, comunicación personal, julio de 2013).

La muerte dispara el dispositivo de elaboración para enfrentar el duelo, como en todos los casos, al hacer del ritual su herramienta más efectiva. Al principio se llora por el efecto inmediato del dolor, después se inicia una cadena de comunicación entre familiares y vecinos para disponer el espacio y los elementos primarios del duelo: la música, el licor, los actores que harán parte y el cuerpo del fallecido vestido y organizado para que no proyecte tristeza.

Se parte de la casa del difunto, se recorre la población y se para entre intervalos para acercar al fallecido al baile, al trago, y al cuerpo de los vivos que lo lloran y lo celebran con cantos tradicionales. La liminalidad se transita desde la vivienda hasta el lugar de entierro, el limen se consume los segundos previos a dejar de ver el muerto, es decir, enterrarlo y despedirse. Según una persona entrevistada «es como tratar de comprender la muerte» (Virginia, comunicación personal, julio de 2014), se incrementa la intensidad en el baile, el consumo y las lágrimas que lo empiezan a dejar ir, a saber, se empieza a elaborar su partida.

El objeto de duelo, al intensificar el llanto, deja liberar su pérdida y evita caer en culpas, melancolía o represiones futuras. Según un actor de este ritual al preguntar por el papel de la elaboración señala: «... esa es una manera de un duelo que a lo último termina siendo lo más de agradable para que la persona elimine las culpas y todo ese asunto» (Virginia, comunicación personal, julio de 2014); el cansancio, producto en especial del baile, y el canto marcan la posliminalidad del ritual y su eficacia simbólica.

Eficacia que se pierde con la intervención de prácticas como la desaparición forzada y, de la mano de ello, aparecen las emergencias subjetivas de duelos sin elaboración, pues «... todo eso se va acabando, se va convirtiendo eso como en un dolor, un sufrimiento, los que logran 
hacer sus rituales, es una manera de sacar a flote sus dolores» (Germán, comunicación personal, marzo 2013). Aquella ya no está; la pérdida es colectiva, solitaria y contenida por el miedo y la incertidumbre.

Si se potenciara en las comunidades el lugar y el significado e importancia del ritual, en especial, de aquellos rituales que sienten como suyos, se podría ver en estos un mecanismo de elaboración legítimo para experiencias de desarraigo tan fuertes como la violencia; potenciar precisamente aquello arrebatado y el territorio que nunca se va del todo, menos cuando existen rituales que lo recuerdan insistentemente.

\subsection{Nuevos rituales}

El principal punto de partida en el caso de las desapariciones forzadas lo constituye la terrible esperanza de que la persona haya sido secuestrada y no desaparecida. Tener una identidad política reconocida por el actor armado, el cual comete el crimen, permite establecer un reconocimiento de la subjetividad del otro, así como sus derechos fundamentales para, de esta forma, albergar la esperanza del retorno.

La primera práctica casi ritualizada de manera natural por las comunidades afectadas por la desaparición forzada la constituye acudir a los conductos propios del Estado, tales como la policía, la fiscalía, medicina legal, el batallón más cercano, entre otros. «... esperando que estén detenidos y que alguien nos dé razón» (Esperanza, comunicación personal, enero 2013). Una de las personas entrevistadas decía: «¿dónde no fuimos?, la fiscalía, la defensoría, a la estación de policía, muchos días dedicados solo a eso, tratando de encontrarlo» (Esperanza, comunicación personal, enero 2013). Este proceso inundado de papeles e impotencia se vuelve un periplo frecuente que, en los casos de las personas entrevistadas, buscaban salir de esa zozobra.

Vale la pena aclarar que esta reacción inicial no coincide con procesos como el argentino donde autores como Schindel (2012) plantean, en buena medida, la inhibición del sujeto por el contexto social, cultural y político que imperaba: 
La desaparición forzada tiene como objetivo, además de la captura de la víctima y la obtención de información bajo tortura, la creación de un estado de incertidumbre tanto entre los familiares como en la sociedad entera. Los allegados del desaparecido no saben cómo actuar ni a quién recurrir, puesto que dudan de los beneficios de la búsqueda, y sufren los efectos paralizantes del terror sembrado por este método (p. 31).

Para el caso trabajado en Colombia sabían que el primer paso era tener la expectativa de encontrarlos allí; búsqueda que implicaba que el actor más fuerte mentalmente de la familia asumiera indagar ¿qué paso?, pues expresaban: «mi mamá estaba destruida, me tocaba a mí» (Germán, comunicación personal, marzo 2013). Este ritual inicial de búsqueda se da en el marco de un escenario social de tensión, ya que la indagación no era solo para encontrar el ser querido, sino para saber cuál fue el motivo y, con ello, descartar si el resto de la comunidad guarda peligro o no.

La temporalidad es vital en ello. Días dedicados a tocar puertas, pero la advertencia permanente de que un primer cierre de ese proceso era huir y mantener las maletas listas para cobijar la vulnerabilidad en la que quedaba el resto de integrantes.

No encontrar respuesta por parte de ningún ente institucional fue común en todos los casos. Posterior a ello y en la mayoría hechos, esta situación implicaba cerrar ese primer proceso de búsqueda, pues al desplazarse fuera del territorio se rompía el conducto inicial, el cual era indispensable agotar en medio del miedo a que le sucediera algo al resto de la familia. Se cerró el principal capítulo ritualizado por el aprendizaje de la experiencia de guerra de otros actores, tal como lo señaló uno de los actores entrevistados: «... ya sabíamos que eso era lo primero que se tiene que hacer» (Virginia, comunicación personal, julio 2014), «... nos agarramos a buscarlo, a buscarlo, a buscarlo y nunca lo encontramos $[\ldots]$ por todos esos potreros por todos esos cafetales, si veíamos un huequito, lo podíamos escarbar para ver si estaba ahí» (Irene, comunicación personal, enero 2015). 
Aquellos que, sin tener el lugar de víctimas de familiares, igual eran víctimas de la desaparición forzada, la cual era asumida como un lenguaje no relacionado con el desaparecido, sino con un mensaje dirigido para toda la comunidad. Estos, con frecuencia, permanecían en su territorio y, desde allí, les tocaba iniciar una readaptación de su vida al caracterizar la ritualidad de la violencia, tales como los códigos de comportamiento establecidos por los actores armados en las zonas afectadas.

Se presentó un cambio en relación con la cotidianidad vivida antes del suceso, y se ejerció un permanente control físico y psicológico por medio de las restricciones de movilidad y libertad del poblador que pasa no solo por la norma instaurada, sino por la comprobabilidad de esta para que fuera real. Una persona expresaba:

Me pasó con la esposa, fuimos al pueblo a una cuestión de odontología y cuando llegamos eran las siete de la noche y ellos colocaban un aviso que "prohibido el paso después de las seis de la tarde", y nosotros llegamos en un camión que nos recogió a las siete y iqué susto!, oscuro, tomados de la mano, cuando apareció la guerrilla y uno se asusta mucho cuando accionan una metralleta, y mi esposa llorando y debido a ella nos perdonaron. Días después mataron a un conductor que pasó después de las siete de la noche, ahí mismo por donde pasamos nosotros. Es que esa gente no es charlando, colocan un aviso y ya (Claudio, comunicación personal, noviembre 2015)

El efecto de estos nuevos rituales de violencia implica una temporalidad donde el que dirige la práctica decide cómo usarla para la efectividad de la misma. Así, la intención central se reduce a tener el control de la población no solo de manera física, sino emocional. Un contexto controlado desde la movilidad y unos ritmos ajustados a la idea de mantener el poder sobre la incertidumbre del otro, inclusive cuando la búsqueda de un desaparecido puede terminar fácilmente con una información clara de lo sucedido. Una víctima atestigua la búsqueda de un conocido por parte de personas cercanas de la siguiente manera: 
El ritual es ir a preguntarle. Pero el ritual es que dejan esperando a la persona. A mi si me tocó eso, que decían: "esperemos y dentro de ocho días nos vemos acá", y lo dejan a uno esperando. Ellos manejan esos tiempos, es la forma de mantener el control. Y presentarse como seres superiores, que ellos tienen la verdad y cuando ellos quieren la dicen (Claudio, comunicación personal, noviembre de 2015).

En la mayoría de los casos abordados la verdad nunca emerge y la búsqueda, por ende, nunca termina plenamente; los pobladores entienden, con estas dinámicas, que el rol primario lo tiene el que controla el territorio físico y social para instaurar y ritualizar un nuevo orden simbólico. Rituales de tránsito, como las lunadas antes mencionadas, cambian con la llegada de nuevos acontecimientos; aunque conservan algunas de sus tradiciones como la música y el baile, disminuye su intensidad y el escenario fundamental para la danza con la luna ya no es el mismo. Un entrevistado dice:

Esos rituales cambiaron en el sentido que cuando ya pasaba ese tipo de cosas, ya la gente no lo hacía, o si lo hacían lo hacían ya amaneciendo, por temor y por muchas cosas así. Muchos rituales cambiaron. La gente se acuesta más rápido, teniendo en cuenta lo que había pasado, la gente ya no salía o se acostaba más temprano (Germán, comunicación personal, marzo 2013).

El significado colectivo empieza a decaer y su posibilidad catártica de igual manera, la esencia de la luna es devorada por la luz del sol, es decir, por el orden inspirado desde el miedo, pues el significante es otro y el ritual, aunque se conserva, mimetiza su carácter por completo.

Cuando se desarrolla un proceso metodológico, al cruzar diversas categorías y a partir de las herramientas de recolección diseñadas, los resultados obtenidos desde instrumentos distintos arrojan la consistencia de la información obtenida, procuran no caer en lecturas ligeras o apresuradas y garantizan la consistencia del dato empírico. 
En el caso de los diarios de campo e instrumentos de observación, emerge un nuevo ritual político desde la condición de víctima como mecanismo de reacción a mediano y largo plazo. Este tiene que ver con la idea de protección y reparación que inicia con una organización estructurada, el nombramiento de un líder, el acompañamiento de sectores religiosos o políticos, una distribución organizativa, unos estatutos y unas reivindicaciones específicas fundamentales para el proceso, tal es el caso de la Asociación Social de Mujeres Desplazadas Cabeza de Familia el Paraíso (ASOMUJPAR), la Asociación de Desplazados El Salado, la Asociación Agropecuaria de Campesinos e Indígenas Desplazados del Naya, el Comité Civil Departamental de Familiares de Víctimas Reparación y Paz (COMFAVIC) y la Asociación de Familiares Victimas de Trujillo (AFAVIT). Estas son algunas de las organizaciones formales y no formales existentes, en su mayoría, creadas como respuesta a la crisis humanitaria en contextos específicos.

Es común ver que un porcentaje alto de los actores involucrados en dichas organizaciones participan de manera itinerante y que en unos pocos recae la conservación del proceso. Esta situación debido a la noción de reparación económica, la cual es el objeto único de interés de algunos miembros, ante otros que buscan una reparación más integral.

De esta forma, cuando el Estado o alguna ONG realiza una intervención pública por medio de alguna de sus instituciones responsables con objetos de reparación material, aparecen, en palabras de un poblador, «... muchos de los que nunca han estado, pero cuando van entregar algo, ahí si llegan» (Virginia, comunicación personal, julio 2014). Este hecho habla también de una performancia social en la cual la comunidad, de manera más homogénea, generaliza su condición de víctima y se confunde en una multitud llena de colores blancos, pañuelos, pancartas y lágrimas incesantes; aquellos que son sujetas y sujetos políticos activos en el proceso reivindicativo con aquellos que, también al ser víctimas, solo juegan un papel instrumental con la organización.

En el caso puntual de AFAVIT, la asociación surgió como respuesta a una crisis y se ha conservado en el tiempo, pero el ritual emergente (todo el proceso de construcción organizacional) no solo tiene que ver 
con una reparación económica, sino con una visibilización del proceso de desaparición forzada, ya que aunque esta tuvo su pico crítico entre 1989 y 1992, ha mantenido niveles de violencia política y desaparición no con aquellos que son considerados auxiliadores de la guerrilla, sino con la misma organización de familiares y víctimas; es decir, el ritual de la violencia como medio de manifestación de control y acallamiento social no remite a una sola generación de víctimas, sino a una nueva generación de victimarios que recurren a esta práctica como medio simbólico para posicionar el fantasma del recuerdo y la repetición continua.

El trabajo de observación sistematizado de la experiencia de AFAVIT deja ver una estructura frágil debido al estancamiento del liderazgo y a la falta de comunicación entre sus miembros. Este arroja como resultado tensiones fundamentadas en lecturas ligeras sobre sus representantes más visibles, pues las personas entrevistadas dicen: «... es que ellos están haciendo plata con lo que nos pasó» (Virginia, comunicación personal, julio de 2014), «... el ya anda con escoltas y todo, viajando por todo lado» (Úrsula, comunicación personal, junio de 2013). Estas son algunas de las expresiones recogidas sobre el presidente o la junta que dirige donde es indiscutible que la ausencia de un relevo en el cargo estanca cualquier proceso democrático y lleva al agotamiento simbólico de ciertas figuras.

Empero, la naturaleza organizacional, cuando alguien visita la población, se ve fuerte, organizada y cohesionada. En este sentido, se construye una performancia social del relato, así como del papel activo de todos en la asociación al hacer hincapié en la necesidad de acompañar el proceso.

\subsection{El ritual del recuerdo}

El relato es un medio terapéutico para el dolor y más para el trámite. No obstante, la pedagogía de la paz que busca promover estos sitios no es igualmente asumida por todos, ya que para algunos existe la convicción del visitante como mediador de la experiencia propia para sanar y no permitir la repetición; para otros el visitante solo es validado 
por la reparación económica y; para unos terceros, existe, con los años, un agotamiento de una escena que no quieren narrar de nuevo donde su interés es dejar de lado la asociación, pero donde nunca pueden tomar distancia realmente de esta.

El recorrido es un proceso ritualizado paso a paso; primero con la sensibilización inicial de la experiencia; después con el intercambio de preguntas sobre lo sucedido y los culpables del hecho, y, posterior a ello, con el tránsito por el parque cementerio, el cual es el monumento construido con ayuda internacional para recordar a los muertos y los desaparecidos de Trujillo. Allí se camina en un viacrucis de la violencia política y social del país, y se hacen estaciones en cada una de las tragedias más violentas del último siglo, a saber, la masacre de El Salado, el exterminio de la Unión Patriótica (UP), la masacre del Alto Naya, la masacre de El Aro, entre otros. Cada uno de estos espacios está acompañado por un tabloide que da cuenta de una referencia histórica de lo sucedido y donde se destaca la ubicación geográfica del episodio, es decir, una cartografía de la violencia que deslocaliza la tragedia en sitios específicos e imprime una noción de incertidumbre e impotencia gracias a las dimensiones de lo sucedido.

La última estación se inicia con el cementerio donde cientos de tumbas se organizan por hileras y de manera sincrónica desde el primer hasta el último asesinado o desaparecido. En cada una de ellas se encuentra un dibujo de la manera como los familiares o amigos lo recuerdan y, al interior, un entierro simbólico de pertenencias de la víctima. El camino es largo como la violencia misma de Trujillo.

Parte de la ritualización implica parar, de cuando en cuando, en algunas de las tumbas para hablar sobre lo sucedido con esa persona o destacar su rol dentro de la comunidad. En palabras de los entrevistados, estos expresaron: «... esta es la de uno de tres hermanos, a los tres se los llevaron» (Úrsula, comunicación personal, julio de 2013), «... aquí está la sobrina del padre Tiberio y sus acompañantes a los lados» (Virginia, comunicación personal, junio de 2014), «... vean esta fecha, esa semana fue una de las más violentas de la tragedia de Trujillo, allá en la vereda La Sonora» (Germán, comunicación personal, marzo de 
2013), «... esta es la mamá de un muchacho que desaparecieron y ella termino muriendo de pena moral, para nosotros ella también es una víctima. Por eso está acá» (Germán, comunicación personal, marzo de 2013).

Un viaje por el sufrimiento padecido, el cual se encuentra acompañado de un relato que se enuncia y envuelve la experiencia con una proximidad mucho más real hacia el dolor de las víctimas. El guía es quién ordena la vivencia ritual por momentos, pues los tiempos son regulados para que el lugar del símbolo sea más efectivo. Después se presenta el limen del ritual en la tumba del padre Tiberio; momento vital en la experiencia ritual, el cual fue sensible y cohesionador de las diferencias entre todas las víctimas de la tragedia.

Un cruce entre la práctica social comunitaria que el sacerdote realizaba y una religiosidad con un manto más que sagrado corporizado en su propio ser, un lazo entre la resistencia social y un fuerte imaginario de entereza del creyente ratificado con dos de las personas que más han acompañado y denunciado la tragedia de este sitio: la hermana Maritze Trigos y el padre jesuita Javier Giraldo. En sus palabras, el sacerdote responder que lo motivó a estar presente en Trujillo:

Cuando ocurrió la masacre de Trujillo, yo estaba coordinando una Comisión de Justicia y Paz en la conferencia religiosa, además yo conocía personalmente desde hace muchos años al padre Tiberio, era muy cercano, muy amigo y evidentemente él desaparece y en la comisión tomamos cartas en el asunto, empezamos a actuar ante las autoridades, a pedir que hicieran algo para buscarlo... (Giraldo, 2012).

Más que una simple postura contemplativa, el rol de ambos estaba legitimado por la gestión de recursos para la reparación integral, entre ellos la construcción del parque cementerio, la capacitación de madres cabeza de hogar, la protección de los lideres amenazados y, ante todo, la visibilización nacional e internacional de la tragedia. 
La tumba simbólica del padre Tiberio está en el centro del cementerio al igual que en medio de la escena ritual en términos temporales. Un actor político que irrumpe entre lo sagrado de su imagen y su papel; así como la crueldad de un victimario, el cual profana su cuerpo con toda la sevicia posible, en el circuito de muerte y desaparición, implican un epicentro que sondea lo que para muchos parecía improbable entre la permisividad de la muerte y la protección simbólico-cultural de algunos actores.

Se continua el camino hasta llegar a una cima donde se han desplegado elementos simbólicos de entidades internacionales y de algunos artistas, los cuales invitan a mantener la reflexión con menos angustia como en el relato del padre Tiberio, pero conservando una reflexión sobre el nivel de crueldad en una escala global con placas que dan cuenta de ello. Al otro lado de la cima se presenta una especie de mausoleo del sacerdote con una foto donde él se encuentra vivo y, al lado, una imagen iconográfica simbólica, la cual es una pintura que retrata su figura crucificada y desmembrada.

Finalmente, se inicia una posliminalidad hasta el punto de partida, pero esta vez obturando la mirada en apuestas estético-artísticas dispuestas en un gran salón, las cuales dan cuenta de formas diversas de recordación y elaboración de las víctimas. El guía da un cierre concentrado en la invitación a la reflexión y a una retroalimentación que indique el deseo y la necesidad de seguir volviendo.

Desde adentro los relatos del recuerdo son diversos y los rituales que se desarrollan o emergen varían en cada caso. La importancia que el actor da entre el acto simbólico y la práctica individual ritualizada marca las diferencias en aquello que Strauss (1984) denomino hace tanto tiempo para la antropología como la «eficacia simbólica» donde la resolución no es tan solo la disposición del sujeto, sino el producto de las tensiones previas, pues su eficacia devela lo que se puede buscar con el acto y lo que realmente se construye en cada caso:

El propósito es llevar a la conciencia conflictos y resistencias que han permanecido hasta ese momento inconscientes, ya sea en razón de su represión por obra de otras fuerzas 
psicológicas, ya sea - como en el caso del parto- a causa de su naturaleza propia, [sic] que no es psíquica sino orgánica, o inclusive simplemente mecánica, no debido al conocimiento, real o supuesto, que la enferma adquiere progresivamente, sino porque este conocimiento hace posible una experiencia específica en cuyo transcurso los conflictos se reactualizan en un orden y en un plano que permiten su libre desenvolvimiento y conducen a su desenlace. Esta experiencia vivida recibe, en psicoanálisis, el nombre de abreacción (p. 222).

Entonces, la práctica ritual implica que la eficacia no se pueda pensar colectivamente y que el trámite, así pase por misas colectivas - como sucede en estos casos - o por elaboraciones simbólicas conjuntas, solo pueda pensarse como un escenario muchas veces catártico, pero no se pueda dimensionar como una elaboración colectiva, ya que el sujeto elige la vía y la gestión más allá de quien oriente el ritual y cuales sean los códigos que intervengan.

Un ejemplo de esto lo constituyen los símbolos más frecuentes como las prendas o las fotos. Estas últimas ocupan lugares diferentes en el duelo y, en algunos casos, implican el único recuerdo que se atesora y solo se expone para los rituales de exposición pública como es el caso de las marchas o plantones, o cuando se desea llevar consigo la fotografía a todas partes, tal como se evidenció con muchos entrevistados, pues estos sacaban pequeñas imágenes laminadas que conservaban en la billetera de forma permanentemente.

Respecto a las fotos como tensiones y alternativas para el duelo, en el caso de una entrevista realizada, fue llamativa la respuesta dada por un actor social después de preguntar sobre el por qué había decidido botar la foto de sus hermanos; este respondió: «... porque he querido sacar ese recuerdo, porque son malos recuerdos, era seguirlos recordando para que no se me perdiera la imagen de ellos, pero a la vez esto era un martirio» (Víctor, comunicación personal, enero 2015).

En ese sentido, varias de las personas con las que se trabajó apelaban a la idea de querer deshacerse de las prendas que simbolizaban más que el recuerdo del desaparecido, a saber, el dolor de no saber nada de 
ellos o, en el peor de los casos, la necesidad de mantener un vínculo melancólico con el objeto de amor perdido, por medio del símbolo más real conservado.

En el caso de una entrevista, la tía de un desaparecido, en relación a su hermana, dice: «... ella la guardo (la ropa), yo me parece que ella todavía tiene esa ropita de él, y ella me dice Yo todavía tengo ropita» (Úrsula, comunicación personal, julio 2013).

En otra entrevista, una víctima habló de una madre y dijo: «... esa señora se estaba enfermando, tenía todas las cosas de su hijo y le celebraba sus cumpleaños con todo eso» (Virginia, comunicación personal, julio 2014). Adicional a ese vínculo con los objetos, la señora mencionada decidió, según el entrevistado, realizar un diario de vida del ausente - desde que nació hasta que lo desaparecieron - con objetos y fotos, contándole y contándose en primera persona cada momento significativo. El punto más crítico fue cuando siguió realizando el diario con todos los acontecimientos importantes después de su desaparición, situación que postergó, en cada anécdota, una especie de sentimiento angustiante que la enfermó cada vez más, según los mismos pobladores conocidos de ella. El descanso vino cuando dejó la mayoría de esos objetos, entre ellos un mapa de la historia de vida de su hijo, el cual había hecho como donación al parque cementerio de Trujillo y donde, finalmente, deja una carta despidiéndose de él.

\subsection{Gracias a la muerte}

El ritual y las creencias «... forman en nuestra conciencia dos círculos de estados mentales, diferentes y separados [...] a un lado queda el mundo de las cosas profanas y al otro el de las cosas sagradas» (Durkheim, 1912, p. 351). Pero, cuando se reconoce la profanación del cuerpo a través de la muerte, así este no aparezca, se sacraliza el lugar del muerto hasta el punto de no dejarlo morir nunca, es decir, se inmortaliza (sagrado) el ausente con la espera aunque se es consciente de su no regreso. Esta situación se coloca en el mismo lado de aquello que Durkheim expresa. 
Así, emergen rituales cotidianos que se mueven entre dichos escenarios con bastante crueldad, hasta el punto donde la muerte termina siendo un triunfo sobre la vida misma. Al preguntar por la aparición de sus hijos una madre contestó en una de las entrevistas:

Nunca, cómo van a aparecer si los cuerpos fueron descuartizados. Uno los espera hasta que uno se muera. Haga de cuenta que es un paseo que ya no se acuerdan de uno. Yo creo que uno nunca deja de esperar, aunque no lleguen. Solo queda orar por ellos para que estén en eterno descanso. Mi esposo murió de las torturas. Es mucha alegría uno saber que está sepultado a pesar de todo [cursiva propia] (Virginia, comunicación personal, julio de 2014).

El recurso simbólico juega un papel indispensable en la cotidianidad. En este caso se procura naturalizar, hasta en el lenguaje, aquello que se padece, «un paseo que ya no se acuerdan de uno» (Úrsula, comunicación personal, junio de 2013), pues no es fortuita la comparación con una práctica agradable como el pasear, pero tampoco el hecho de que esta metáfora de cuenta precisamente de un viaje.

El símbolo en el ritual es el mecanismo de interacción primario y adquiere valor en las elaboraciones lingüísticas que se teje con base en el mismo. En el caso mencionado, la dicotomía entre lo sagrado y profano, lo vivo y lo muerto, y la espera y la resignación llevan a ubicar el símbolo con valores cotidianos que cambian dependiendo de la escena ritual asumida: levantarse, ir a trabajar, denunciar lo sucedido o recordar en la intimidad. En las palabras de una persona entrevistada:

Allá están mis dos hijos. Eso es simbólico porque ahí solo está el cajoncito y el nombre de ellos y la imagen de lo que ellos trabajaban. Que eran moreros, que eran cafeteros. Yo de ellos solo conservo una foto [...] así uno tenga psicólogo, uno siempre está recordando todo lo que pasó. Paz no va a haber nunca (Virginia, comunicación personal, julio de 2014). 
La doble condición anuda símbolos rituales; por un lado, con las expectativas de la religiosidad; y, por otro, en especial desde el catolicismo en cuanto a la vida y la muerte.

En otro caso, un hermano en relación con su desaparecido decía cuando alguien le dio una respuesta: «... ese guerrillero me dijo, no espere más a su hermano que a él lo mataron, y eso fue como un descanso porque le creí al señor. Me lo dijo con tanta sinceridad que yo dejé de buscarlo» (Germán, comunicación personal, enero 2015). En el mismo marco del relato insistió, por momentos, en lo imposible de creerles y en que lo habían extorsionado no grupos guerrilleros, sino miembros retirados de los mismos, por lo que él no confiaba en ninguno. Sin embargo, más por recurso simbólico que por elementos de juicio, decidió tomar esta afirmación como un criterio para cesar su búsqueda y descansar un poco, es decir, para creerles.

Líneas después afirmó lo siguiente en relación con otro hermano también desaparecido, el cual según él apareció por accidente después de muchos años:

Entonces yo digo que si este apareció treinta y dos años después, de pronto este otro también puede aparecer vivo, yo confío en los diálogos con el ELN [Ejército de Liberación Nacional], pero eso no se sabe, yo estoy más seguro que está muerto que otra cosa (Claudio, comunicación personal, noviembre de 2015).

La movilidad de un lugar a otro en el discurso, entre la vida y la muerte, es la misma muestra del estado de su hermano. Precisamente, el recurso simbólico ante la incertidumbre y el deseo de una certeza se presentó al final de la entrevista cuando, al indagarle por lo que le evoca la foto conservada de su hermano después de tantos años, responde: «Esperar, me genera más la palabra esperanza la foto. Esa es la palabra que se me ocurre» (Germán, comunicación personal, enero de 2015).

La religión, al igual que la magia, tiene su origen y función en situaciones ligadas a un conflicto deseo-realidad, aunque, mientras que la magia es un arte práctico establecido en una relación medios-fines, la religión es un corpus donde medios y 
fines se autocontienen a sí mismos. La magia apunta a resultados directos, la religión intenta apropiarse y reducir la angustia sobre cuestiones más existenciales, abstractas o fatales, como la muerte (Apud, 2011, p. 11).

Una espera sin esperanza en la cual no se deja de orar por aquel asumido como muerto, pero que, finalmente, no se deja ir debido a la presencia de su recuerdo y la ausencia de su cuerpo, el cual se busca de cualquier manera - vivo o no-, lo cual, al no encontrarse, impide aceptar su trámite e iniciar la elaboración real del duelo.

Todo ello porque el cuerpo desaparecido no retorna ni con magia ni con religión; por el contrario, el ausente se inscribe en el intermedio entre la voluntad de Dios y la suerte. «Eso cambió mucho la vida totalmente, yo era un comerciante próspero, tenía almacenes, tenía empleados, tenía dinero y eso prácticamente derrumbó todo» (Germán, comunicación personal, enero de 2015). Esta fue la respuesta al interpelar a uno de los entrevistados sobre la idea insistente que planteaba frente al tema de la suerte en lo sucedido a él y a su familiar.

De igual forma, el respeto de la divinidad también se rompe ante la angustia, a pesar de la histórica tradición o vocación religiosa de un actor social, situación que los ubica, en ocasiones, en aparentes lugares incomprensibles para sus creencias. Respecto a esto se expresó: «Es una cosa muy rara, yo he sido muy creyente, creo en Jehová Dios, y muchos de mis poemas son basados en Dios. Pero tengo como rota la comunicación de oraciones con él» (Claudio, comunicación personal, noviembre de 2015). 


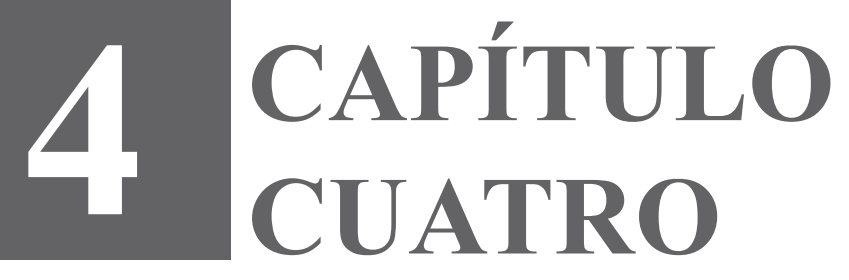




\title{
EI testimonio y la memoria como puente entre la pérdida y los rituales. El caso Trujillo
}

\begin{abstract}
Repasa y reposa la escena de lo acontecido, no deja escapar detalles, como si en ellos conservara el vínculo con sus hijos, el diálogo se hace prolongado, extenso y preocupado por narrar minucias, no quiere dejar escapar nada en su relato, que todo quede ahi atrapado por el lenguaje, ese que termina siendo el real sobreviviente a los años

(Diario de campo-Trujillo).
\end{abstract}

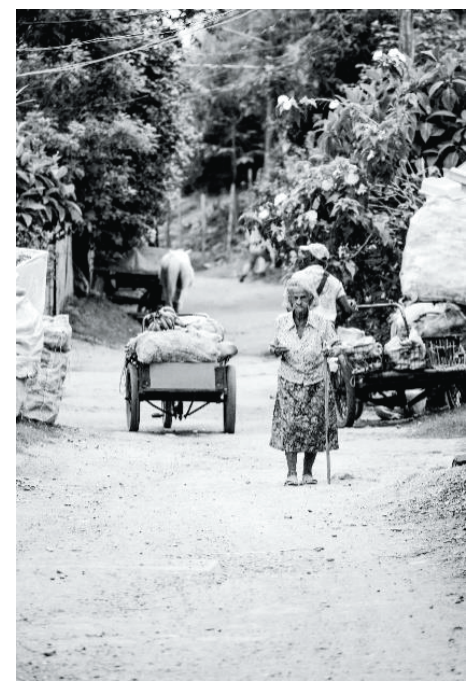

Fotografía por Jhon Hurtado

A pesar de que son muchas las comunidades afectadas por la violencia en el país y cada una de ellas tiene improntas propias en su dolor y en su trámite o, por lo menos, en el intento de seguir adelante, es fundamental caracterizar casos puntuales que sirvan como referentes de 
análisis para la comprensión de unas y otras no de manera homogénea, pero sí de forma focal donde pueden coincidir algunos de los criterios de reflexión o algunas de las herramientas usadas para ello.

Se inició esta tesis con una conceptualización histórica de la desaparición forzada; luego se hizo una precisión del concepto del ritual y su relación con este tema en el caso colombiano; se trabajó después sobre algunas prácticas rituales que se conservaban, se readaptaban y aparecían en comunidades, las cuales migraron y se reasentaron en distintos sitios del territorio. En el capítulo anterior se desarrollaron algunas de aproximaciones desde la subjetividad y el trámite psíquico de este suplicio.

En este capítulo se inicia una relación entre el testimonio y la memoria desde acontecimientos traumáticos para articularlo después a un caso puntual de desaparición forzada donde se desarrolló buena parte del trabajo de campo, es decir, Trujillo, Valle del Cauca. Aunque el objeto de estudio no tenía énfasis en lo territorial, pues se trabajaron las entrevistas tanto en esta población como en comunidades reasentadas de la ciudad de Pereira, departamento de Risaralda, es importante dilucidar que no se hizo hincapié en la categoría.

Empero, esta situación no implica desestimar la importancia de hacer un ejercicio focalizado como el desarrollado en este capítulo y en una población en la cual se tuvo acceso de diferentes formas y se permitió el progreso de una buena parte de lo encontrado en este trabajo de investigación.

\subsection{La memoria y sus pasados ${ }^{3}$}

Un puente que se puede trazar desde la condición subjetiva de la pérdida, en el caso de poblaciones afectadas por la desaparición forzada, hacia las elaboraciones rituales colectivas, con o sin un duelo elaborado, lo presenta el abordaje metodológico que, conceptualmente,

3 El contenido de este acápite parte de la reescritura y ampliación de la ponencia «Memorias de la violencia política, la desaparición forzada y el ritual mediador» (2018), llevada a cabo en la Octava Conferencia Latinoamericana y Caribeña de Ciencias Sociales en Buenos Aires, Argentina. 
ofrece la voz testimonial de la memoria; esta como la representación de un acontecimiento sucedido, pero con anclajes sociales que relacionan el discurrir apalabrado del individuo (la narración de un fenómeno), con el significante propio establecido por la comunidad ante unos códigos comunes de entendimiento (el significado colectivo de del mismo).

Un ejemplo de ello lo constituye el indagar el testimonio frente a elementos como: probables causas que generaron la desaparición, actores dinámicos en la comunidad al momento de la desaparición, características diferenciales entre actores desaparecidos o entre las condiciones de una u otra desaparición, significado del territorio al momento del episodio, reterritorialización del conflicto, entre otros. El valor radica en el hecho de que cada inquietud implica una historia enunciada por los individuos con lugares comunes, al igual que evidentes diferencias en el abordaje de lo preguntado.

Para ello es importante formular una ruta desde la memoria como representación subjetiva, hasta su rol como elucidación del pasado para la construcción del futuro en una comunidad.

Cuando por primera vez Halbwachs (2004) establece la relación entre la memoria individual y la memoria colectiva, éste indica la importancia del sujeto como testigo de su propia evocación ante el recuerdo, «ahora bien, el primer testigo al que siempre podemos recurrir somos nosotros mismos» (p. 25), estableciendo de antemano la percepción como un punto detonante en la elaboración del pasado desde la noción misma del individuo.

Sin embargo, más adelante aclara, que es en la construcción del sentido colectivo donde se puede pensar un significante del pasado, los grupos establecen sentido con su pasado, valores que les permitan una identificación que haga parte de su acerbo en donde en ocasiones no se discierne con claridad entre el recuerdo individual y la memoria colectiva: «Desde el momento en el que nosotros y los testigos formamos parte de un mismo grupo y pensemos en común en determinados aspectos, seguimos en contacto con dicho grupo, y somos capaces de identificarnos con él y confundir nuestro pasado con el suyo» (p. 25). 
De esta forma, entendemos la memoria como un «hecho social», una construcción de acontecimientos ocurridos en un tiempo atrás, los cuales son cargados por un grupo o colectivo adherido bajo un significante común. Según Halbwachs (2004) tal noción de la memoria se encuentra delimitada por unos marcos sociales que la definan, estos marcos son: la religión, la familia y la clase social, el primero como sentido que el sujeto imprime en su vida, el segundo por ser el responsable de la introducción del sujeto en la sociedad bajo un sentido del pasado y el tercero como producto de una memoria que en cada época las clases dominantes establecen bajo sus conveniencias.

De igual forma, define unos marcos sociales más específicos tales como: el lenguaje, el espacio y el tiempo, siendo el primero el que muestra la naturaleza interlocucional de la memoria y por efecto el carácter social de esta.

Halbwachs (2004) nos muestra una noción colectiva y unos marcos que la definen, donde al margen de críticas como la de Barry Schwartz (1992), por ver en el trabajo de Halbwachs una sobredimensión del presente, en la cual se marginan los hitos que desde el pasado se reclaman de forma atemporal a lo que las sociedades eligen, como lo ejemplifica él con la figura de Abraham Lincoln ${ }^{4}$. A pesar de esto Halbwachs logra establecer la cuestión social de la memoria, destacando el lugar del significante colectivo como criterio de cohesión e identificación grupal ante el recuerdo o la construcción del pasado en el presente.

En ese sentido, al relacionar ya de manera contextual para el trabajo de investigación la memoria con hechos concretos de desaparición forzada, se establece un vínculo entre la evocación del sujeto ante el episodio y su forma de recordarlo-narrarlo frente a un colectivo, teniendo en cuenta la precaución en algunos casos de no darle un significante público por lo que puede implicar para la eventual aparición o para

4 Se menciona la crítica de Schwartz, pues este permite ver un panorama más amplio de los debates que sobre la memoria y el pasado se construyen; sin embargo, es claro que lo resaltado de la obra de Halbwachs permite una comprensión de la memoria como construcción social en las elaboraciones colectivas y que estas, precisamente por su carácter protagónico en la identificación de un grupo, pueden girar desde su tradición hasta su representación del presente donde se materializa. 
su propia seguridad como víctimas, se trata más bien de establecer una pausa en el discurso que atrapa dicotómicamente el recuerdo y el olvido, en un círculo narrativo sobre el pasado.

Empero, se puede pensar de un lado tal situación narrativa desde la idea de olvidar de manera grupal, esto como un significante común emergente, el cual busca establecer en el deseo de silenciar el recuerdo una forma de encarar el futuro; pero del otro lado, las rupturas que el lugar del pasado establece en diferentes grupos sociales, otros significantes del mismo hecho también comunes entre diferentes actores, en algunos casos problematizando las dinámicas de cohesión social, donde miembros de la comunidad empiezan asumir sus propias dinámicas con el testimonio.

Es decir, los que buscan olvidar y seguir adelante, los que quieren recordar para reclamar justicia, los que prefieren omitir lo sucedido, pero esperan un retorno, los que persiguen la reparación como duelo simbólico de la pérdida, los que simplemente hacen del recuerdo un hecho transitorio que introducen o normalizan, los que naturalizan la violencia como dinámica cotidiana, trivializando la condición del desaparecido como parte normal de un conflicto.

Ejes y criterios de la memoria que se juegan en el testimonio, paradoja contemporánea en la palabra de los miembros de comunidades afectadas por la desaparición forzada en el caso colombiano, ya que en este proceso se excede el marco de lo establecido por la teoría clásica y parte de la teoría actual sobre el tema, gracias a que en el caso de autores como Jaspers (1998), Arendt(2007), Adorno (1998) o Habermas (1998), por mencionar algunos, o de casos más cercanos en Suramérica como los trabajos de Elizabeth Jelin (2017), Ludmila Catela (2002), Cintia Gonzales (2011), Pilar Calveiro (1998) o Steve Stern (2014), todos construyen una relación entre el pasado y su cosificación en el presente, pero asumiendo el cierre de un episodio histórico, un corte que permite volver sobre el fenómeno, a partir de un marco concreto, un acontecimiento, sus efectos y su final (Los nazi, las dictaduras en el cono sur, etc.), algunos de estos autores destacan el valor de asumir la discusión moral del pasado y su indispensable lugar para la elaboración 
de un futuro, como garantía para la necesidad de no repetición, al contrario en el caso investigado no existe un punto de cierre, no existe un corte y por ende no hay un pasado concreto al cual mirar o reparar.

Por ejemplo, a diferencia de buena parte de la teoría sobre el tema, la comunidad de Trujillo, Valle en Colombia como en muchos otros lugares del país, la desaparición forzada es un fenómeno que aún late con violencia, tanto porque todavía se registran casos de desaparición a pesar de años de intervenciones de múltiples actores, como porque no se ha registrado procesos claros de una reparación colectiva integral ${ }^{5}$ que vincule de manera articulada los miembros de la comunidad bajo un mismo territorio físico y simbólico.

De ahí la paradoja que se presenta en este caso; desarrollos tanto éticos como políticos en una discusión bastante agitada desde mediados del siglo pasado a nivel mundial, frente a la comprensión de la memoria local, y un conflicto que supera una delimitación posible para el uso o la reflexión de tales criterios, pues la temporalidad establecida, así como el territorio para la continuidad del futuro, no es aún aprehensible y, por el contrario, el ejercicio mnémico que desarrolla la población se ve instigado con frecuencia.

Infortunadamente, no se trata de hablar tan solo del lugar del pasado en el presente, ni tampoco, como lo desarrolla Adorno (1998), de «un pasado no superado», el cual, al no asumirse conscientemente, puede invadir el futuro. Se trata más bien de un campo de tensión entre un pasado inmediato, una deriva con ese recuerdo aún vivo, múltiples

5 Se debe destacar que desde el primero de enero de 2012 inició la ejecución de una nueva ley de víctimas y restitución de tierras por parte del gobierno colombiano, la cual pretende cubrir la reparación y la devolución de tierras desde 1986. Sin embargo, aún quedan interrogantes, tales como la forma de operacionalizar el proceso, pues como lo señala un funcionario de la defensoría del pueblo en el municipio de Pereira, los formularios son muy extensos y confusos, los que buscan inscribirse en el programa en la mayoría de los casos no los entienden y no existen personas destinas para brindar asesoría sobre ello. Por otra parte, también se cuestiona la tipificación de la condición de víctima, así como las diferencias en cuanto a la reparación de cada una de ellas; quizás el interrogante más importante frente al nuevo proyecto de ley lo constituye la profunda ausencia de procesos de justicia que aborden con claridad el tema de las responsabilidades y condenas jurídicas. 
emergencias testimoniales y un futuro atrapado por ese pasado-presente de violencia y de impunidad, el cual construye un marco de temporalidad confuso y convulsionado por sus límites.

En ese sentido, el dolor ni siquiera se deja sentir con plenitud, pues el cuerpo del desaparecido está perdido entre el miedo a la repetición, la censura social por ser un tema frágil para la comunidad y la impunidad de no hallar justicia.

¿A qué apostarle entonces?, ¿resolver el pasado, construir el presente o proyectar el futuro? ¿Cómo pensar la memoria de un fenómeno traumático cuando la narrativa aún se sigue escribiendo?, ¿cómo ir tras un testimonio de lo sucedido cuando el pasado aún desarrolla el presente de una comunidad?, ¿cómo desvincular responsabilidad y memoria para que el testimonio no se enfrente con sus propios miedos?, ¿es posible tal escisión?

Antes de realizar algunas consideraciones sobre estas preguntas, es importante tener en cuenta que la presencia actual de la violencia, en relación con el pasado y el carácter latente de la memoria que aún se construye, tiene varias maneras de entenderse. Primero, una violencia directa que sigue apareciendo expresada por medio de actos como la desaparición forzada, los asesinatos o las instigaciones a la comunidad; segundo, un pasado que estigmatiza la población por considerar el territorio continuamente como zona de alto riesgo; y tercero, un pasado que se ve en deuda, tanto por la espera del desaparecido, como por la búsqueda de una verdad que traiga justica ante lo sucedido.

Esta última variable se encuentra sujeta, en muchos casos, a la imposibilidad de hablar de lo sucedido, de nombrar la existencia de víctimas o verdugos, o de mencionar un acontecimiento pasado que marcó una ruptura con la vida social de la comunidad.

A pesar de destacar el lugar de la diversidad en los testimonios de los miembros de comunidades afectadas por la desaparición forzada y no solo de familiares de víctimas, en todos los casos la narrativa construida trajo consigo una consecuencia que condiciona las anteriores preguntas expuestas, ya que la responsabilidad en lo dicho no solo fue con el 
otro, sino consigo mismo en un contexto de estigmas y señalamientos sociales que, muchas veces, recayeron sobre el desaparecido, la causa que llevó al acontecimiento e, incluso, en zonas muy delicadas de testimonios que implican amenazas o retaliaciones contra la población ${ }^{6}$.

El sufrimiento de lo acontecido se transforma en amenaza de lo que puede acontecer y el recuerdo se presentifica como instrumento de doble filo: deseo de volver para recuperar lo que ha sido arrebatado (no solo el retorno del desaparecido o su cuerpo sin vida, sino toda lo simbólico que se llevaron con él y le pertenecía a toda la comunidad), y miedo de evocar fuerte y provocar la repetición del fenómeno. Retomando a Adorno (1998) en relación con el régimen nazi:

Se tiene la voluntad de liberarse del pasado: con razón, porque bajo su sombra no es posible vivir, y porque cuando la culpa y la violencia solo pueden ser pagadas con nueva culpa y nueva violencia, el terror no tiene fin; sin razón porque el pasado del que querría huir aún está sumamente vivo. El nacionalsocialismo sobrevive, y hasta la fecha no sabemos si como mero fantasma de lo que fue tan monstruoso, o porque no llego a morir (p. 15).

Coinciden las palabras de Adorno respecto a la noción infinita del terror con la vitalidad del pasado violento en el presente; sin embargo, se diferencia en la incertidumbre de no saber si realmente se quiere librar del pasado, si se quiere huir de él, si eso implicaría en la consciencia moral un abandono al desaparecido o a su imagen y si librar es callar y callar es autorizar de nuevo una posible repetición, pues el recuerdo se mantiene vivo, pero se encuentra atrapado por su destino en las manos de un relato. Un testimonio condicionado por la responsabilidad entre el deber y el querer no solo con un amigo, vecino o familiar desaparecido, sino con todos los miembros que hacen parte del territorio.

6 El carácter selectivo de un asesinato o de una desaparición forzada, en un lugar determinado, implica en el caso de la violencia política un mensaje dirigido no solo a los familiares de la víctima, sino a toda la población. En determinados casos es común el señalamiento como una aparente forma de protección por parte de algunos ciudadanos, pero es claro que la retaliación no se asume como un mensaje focalizado, sino como todo un efecto que cambia las lógicas sociales directa o indirectamente de todos los que hacen parte del territorio. 
Proteger y protegerse con cuidados físicos y también con reacciones psicológicas que elijan consciente o inconscientemente una opción con el recuerdo. Siguiendo Adorno (1998):

La cancelación del recuerdo es más un rendimiento de la consciencia demasiado despierta que su debilidad frente a la prepotencia de los procesos inconscientes. En el olvido de lo apenas ingresado en el pasado resuena la exasperada creencia de que lo que todos saben tiene que excusarse a sí mismo antes de poder pedir a los otros excusas por ello. Todas estas reacciones, actitudes, modos de comportamiento no son, ciertamente, racionales en sentido inmediato, toda vez que desfiguran los hechos a los que se refieren (p. 19).

La historia política de Colombia se ha visto atravesada, con frecuencia, por estas mismas vicisitudes; no solo en cuanto al tema de la desaparición forzada, sino en temas como el desplazamiento, el asesinato, la pobreza extrema, los desalojos, entre otros, situaciones que dan cuenta de una serie de exculpación del ciudadano en nombre del progreso, el desarrollo o, en algunos casos, de la naturalización cotidiana de diferentes grados de violencia. A pesar de la primera impresión irracional que aluden estas actitudes, el mismo Adorno (1998) contextualiza el fenómeno bajo una rúbrica contemporánea y dice:

Son racionales en la medida en que se apoyan en tendencias sociales y en que quien reacciona así se sabe en sintonía con el espíritu de los tiempos. Esta forma de reaccionar se ajusta de modo inmediato al imperativo de salir adelante y hacer progresar. Quien no tiene ideas estériles, no tira arena en la maquinaria para dificultar su funcionamiento (p. 19).

De esta forma, se llega al ápice del testimonio, a saber, a la sutil línea que lo distancia de una responsabilidad política y de una consciencia moral que, si bien, se asume con una lectura en el caso puntual abordado, es fiel espejo de una génesis política tanto en Colombia como en diferentes países de América Latina e inclusive del mundo. 
El silencio y la complicidad explícita de esta adenda; la palabra y el respaldo en nombre de un desarrollo mayor, pero no más incluyente; la acción y su efecto por encima de una simple práctica cotidiana.

Factores tangenciales que desvelan la matriz moral de un pueblo ante la participación de cada uno dentro de la misma. Por tal motivo, el pasado se vuelve tan indispensable a la hora de pensar el futuro, pues esa forma de asumirlo es la manera como las personas se juzgan a ellas mismas, lo que Habermas (1998) llamó «el autoentendimiento ético-político», el cual evalúa los seres, al tiempo que los puede poner al descubierto ante aquello que se hace, pero se pretende omitir gracias a la responsabilidad que encierra. Levi (2002) ilustra a Rumkowski ${ }^{7}$ como un caso bastante sugerente para esta condición ambigua de la moral al decir:

En Rumkowski nos vemos todos, su ambigüedad es la nuestra, connatural a nosotros, de híbridos amasados de arcilla y de espíritu; su fiebre es la nuestra, la de nuestra civilización occidental que - baja al infierno con trompetas y tambores-, y sus miserables oropeles son la imagen distorsionada de nuestros símbolos de prestigio social (p. 527).

La consciencia de los actos es connatural a la racionalidad moral que los convoca. La cohesión que implica el orden social obliga a pensar la responsabilidad como una condición inherente que involucra el pasado, el presente y el futuro; y donde cada actor social se hace cargo de aquello que hace o dice en relación consigo mismo y con los demás.

Pensar el grado de responsabilidad de cada individuo resulta bastante difícil a la hora de comparar la condición en la cual se desarrollan procesos de violencia extrema, tales como la desaparición de personas en zonas de conflicto, en relación con procesos de violencia «cotidiana»

7 Chaim Rumkoswski, industrial judío que ejerció como presidente del gueto de Lodz en Polonia. Fue nombrado por los alemanes en este cargo en 1939; se le conoció por sus excesos y su ambición. Su polémica figura es bastante cuestionada en relación con el papel de facilitador del genocidio nazi en el mayor gueto judío, en medio de calificativos como traidor, colaboracionista, megalómano o enfermo. Este muere en una cámara de gas en AuschwitzBirkenau el 28 de agosto de 1944. 
como sucede en las ciudades, y en los procesos de reurbanización y desarrollo no por el grado de intensidad de una u otra, sino por el efecto subjetivo inmediato que esta posee en cada caso. Es decir, la violencia no se mide por grados ni por niveles de agresividad, pero el efecto en cada escenario varía y no tiene la misma consecuencia en el cuerpo social; particularmente el caso de la desaparición forzada en zonas rurales en relación con las prácticas de marginación o exclusión en las zonas urbanas, las cuales, muchas de ellas, han sido naturalizadas por la población.

Primero, una impresión del orden de lo traumático deja una herida abierta y con riesgo de empeorar, lo cual ocasiona una tensión entre los síntomas que tramitan la experiencia de la pérdida y la angustia para enfrentar aquello que puede regresar como amenazante. Segundo, una sucesión que normaliza el nivel de tolerancia ante episodios como el estigma, la segregación, el desplazamiento, la limpieza social ${ }^{8}$, entre otros, muchas veces con la visión borrosa, como lo dice Levi (2002) «nos cegamos con el poder y con el prestigio social hasta olvidar nuestra fragilidad esencial» (p. 527); en este caso, la dinámica contemporánea en las ciudades conlleva a códigos móviles entre aceptar, rechazar o ser cómplices aparentemente inocentes bajo la tutela de los cambios hacia el futuro.

A pesar de ello, un núcleo común da cuenta en ambos campos en cuanto al carácter social del hecho, ya que la responsabilidad en un contexto de interrelaciones determina cómo el horizonte del presente está marcado por los acuerdos no solo de convivencia, sino de supervivencia construidos por una comunidad. Así, los efectos del compromiso superan la dicotomía básica de víctimas y verdugos, y ubican a las personas en un plano activo donde son participes plenos de acciones y reacciones con lo que esto implica en ellos mismos y en los otros que los rodean.

8 Término usado en Colombia cuando se dan muertes por parte de escuadrones generalmente de paramilitares, a los habitantes de calle, drogadictos o ladrones. Normalmente se apela a la idea de una limpieza de aquello que «ensucia» la sociedad y es una muestra significativa de justicia por propias manos, al igual que de estigmatización social por medio de frases como: «algo debía», «no le servía a la sociedad», «matan es a desechables». 
Al respecto, Arendt (2007) decía frente a otro caso y al tomar como referencia la responsabilidad de algunos mandos medios en el régimen nazi:

Políticamente hablando, la debilidad del argumento ha sido siempre que quienes escogen el mal menor olvidan con gran rapidez que están escogiendo el mal [...] Más aún, si nos fijamos en las técnicas del gobierno totalitario, resulta obvio que el argumento del "mal menor", — lejos de ser esgrimido sólo [sic] desde fuera por quienes no pertenecen a la élite rectora- es uno de los mecanismos que forma parte intrínseca de la maquinaria del terror y la marginalidad (p. 64).

Esta situación sirve de referente para pensar en las elecciones de los miembros de comunidades afectadas por la desaparición forzada con particularidades como las mencionadas. Cualquier decisión como la jugada en la palabra implica la construcción de un testimonio donde yace la responsabilidad familiar y colectiva ante actores dinámicos y al interior del mismo territorio.

Perpetradores, víctimas y testigos muchas veces cohabitan, lo cual obliga a que la sola asunción de la voz ante un agente externo denote el camino entre el inocente y el culpable con bastante fragilidad; una lucha que sigue librándose en el presente y arrebata miembros de una comunidad donde desaparece el cuerpo y, con él, la tranquilidad colectiva en el acto.

Es por este hecho que el sujeto se ve forzado a tomar un lugar frente a lo que se dice, se calla, se omite o se esconde dentro de una memoria escrita sobre el momento actual. En las preguntas antes mencionadas se ve un epicentro fundamental en la responsabilidad del sujeto con su presente, la bifurcación de la memoria del acontecimiento, y la necesidad de elaborar una pérdida y asumir un porvenir como posible; la elección compelida no como en el caso de Arendt en el pasado de un pogromo sucedido, sino como una tragedia aún en ejecución. 
Hacer un juicio del momento vivido, del lugar de la pérdida, de la esperanza de retorno y de los efectos de lo mencionado con este lleva a narraciones más allá de una teoría de la memoria y sus vínculos sociales, ya que se debe entender, según la misma Arendt (2007), como el alto riesgo de la indiferencia frente a quién se decide esté con uno mismo en la construcción colectiva de presente, «... moral e incluso políticamente hablando, esa indiferencia, aunque bastante común, es el mayor peligro» (p. 64). Así, las personas se enfrentan al riesgo de la voz y del silencio; ambos aspectos importantes, peligrosos y, más aún, en las posibles consecuencias de una memoria del día a día ante un cuerpo que algunos esperan, otros dejaron ir y otros, sin saberlo, lo trajeron de vuelta en sus prácticas cotidianas.

Este es precisamente el foco central del fenómeno y, a su vez, de las derivas investigativas cuando se aborda la inquietud metodológica ante el testimonio y el valor moral y político que este guarda en sí mismo.

Testimoniarse es la narración inicial que teje el actor sobre su propia historia, tal como se mencionó con Halbwachs; es el primer paso de la percepción ante el recuerdo en un episodio traumático, pues reconstruir la escena y articular un discurso responsable o, por lo menos, mínimamente seguro para el actor requiere pensar factores dinámicos en la temporalidad (pasado-presente-futuro) de aquello que afecta la psique del sujeto.

En el caso de las desapariciones forzadas acompañadas de asesinatos selectivos en Trujillo Valle, es bastante clara esta característica, ya que el primer caso registrado se dio a finales de los años ochenta y, desde ahí, la desaparición en la zona fue sistemática hasta 1994 con puntos críticos en 1990, pero con casos aún sin denunciar y hechos aparentemente aislados hasta el año $2010^{9}$.

El relato es toda una travesía sobre el tiempo que muestra aristas dolorosas y peligrosas; en este caso se hace complejo el testimonio y su efecto con lo ocurrido. Arendt (2007) en relación con la selección de

9 Hasta el momento la fiscalía general de la nación reconoce 342 víctimas entre asesinados y desaparecidos en el periodo comprendido entre 1986 y 1994. 
uno de los testigos usados contra Eichmann, el cual solo quería relatar aquello que le permitía una alusión particular no muy clara frente al caso, decía:

Evidentemente, lo anterior constituyó una excepción que demostró la regla del comportamiento normal de los demás testigos, pero que no demostró la regla de la simplicidad, de la capacidad de relatar lo sucedido, y menos todavía de la muy rara capacidad de saber efectuar una distinción entre lo realmente ocurrido al declarante dieciséis, y a veces veinte años atrás, por una parte, y lo que había leído o imaginado desde entonces, por otra (p. 13).

Es distinto entender el uso de tal simplicidad cuando se hace una revisión crítica de los acontecimientos que rodearon el caso analizado por Arendt, ya que la reflexión se establece sobre el cierre de un proceso genocida y la apertura de un proceso judicial con las heridas que esta situación abre.

En el caso de Trujillo, la incapacidad de discernir no es tan solo una reacción emotiva, sino una responsabilidad que se juega sin cierre de ningún tipo donde entran elecciones discursivas, emotivas, esperanzadoras, derrotadas y tácticas ante un hecho inconcluso, pues el cierre - así se dejen de presentar desapariciones - no se construye solo desde la necesidad de esta garantía básica de vida, sino sobre la intención y la preocupación real del Estado por la verdad y la justicia.

De esta manera, el testimonio y la responsabilidad hacen un entramado amplio desde diversos autores, pero requieren una exégesis que ubique el contexto y su propia naturaleza, pues la memoria del testimonio está compuesta por la responsabilidad no como consciencia moral de lo que se debe o no recordar, sino como actitud política ante un medio social vulnerable como el caso mencionado anteriormente.

El 10 de marzo de 2009 se liberó al coronel retirado del Ejército colombiano Alirio Antonio Urueña, el cual era teniente de la policía al momento de las masacres y desapariciones perpetradas en Trujillo. 
Su captura se había ordenado tan solo un año atrás y se argumenta que los cargos imputados por la Fiscalía General de la Nación debieron ser homicidio agravado y no con fines terroristas, es decir, es liberado por mal procedimiento.

Después de veinte años, y gracias a la magnitud y la sevicia de lo ocurrido en Trujillo con un proceso de justicia tan incompetente, es inverosímil pensar un recurso a la memoria fiel y a los hechos, el cual sea libre de condicionamientos en su evocación. Las consecuencias de lo ocurrido y la negligencia en la protección y reparación de la población han vertido una atmosfera densa para la memoria, tanto en el campo de lo consciente como en lo inconsciente que esta encierra.

De esta forma, se ve un último lazo entre memoria y responsabilidad no desde el papel particular del sujeto envuelto en el proceso, sino desde la responsabilidad en las instituciones y su lugar dentro del ámbito de la justicia.

\subsection{Responsabilidad política}

El decreto de olvido, al igual que el de memoria como responsabilidades sociales, implica una noción ética de lo correcto e incorrecto, y de lo que una sociedad debe hacerse cargo. Los usos de la memoria vacilan entre la manipulación y ante aquello que Adorno (1998) llamó una tendencia, a saber, «... la endurecida actitud de los que nada quieren saber de todo ello no dejaría, ciertamente, de sintonizar con una poderosa tendencia histórica» (p. 17). En ella las responsabilidades pasan por la exoneración de pasado y sus culpables como sucedió en el caso argentino con las leyes de obediencia debida y punto final, y por la memoria como recuerdo obligatorio con el presente para pensar un futuro posible. Aquí se asumen culpas ajenas o se exoneran obligaciones en nombre de una culpa colectiva, y se hace gala de la memoria como dispositivo útil en la construcción de identidad nacional.

Un ejemplo de ello son las distintas reacciones generacionales de la posguerra y sus atribuciones morales en lo sucedido, tal como ocurre con las disculpas públicas de mandatarios años después de los 
acontecimientos. Este es el caso de Willy Brant, canciller alemán ante el memorial del gueto de Varsovia en 1970; Tony Blair por la hambruna ocasionada a los irlandeses en 1845; Frederick De Klerk expresidente de Sudáfrica, el cual declaró, al dejar su mandato, «el apartheid fue un error»; Juan Pablo II por el papel de la iglesia en la Segunda Guerra Mundial o Nestor Kirchner por veinte años de impunidad en Argentina.

Pensar políticamente el lugar de la memoria y las formas de representación que impulsan o persuaden un Estado, en nombre de la unidad nacional, requiere problematizar lo que se pretende con el uso de estas en distintos escenarios donde, sin lugar a dudas, uno de los más apelados en los últimos años y a nivel mundial reposa en el deseo de olvido como método de reconciliación, de perdón o de impunidad. Se focalizan unas situaciones particulares, en especial aquellas donde el mismo Estado se ve involucrado y se le da un tratamiento ligero bajo la premisa de superar viejos rencores. Tal pretensión ingenua, como lo sugiere Arendt (2007), no tiene asiento en la realidad histórica de la humanidad, pues

Las bolsas de olvido, no existen. Ninguna obra humana es perfecta, $y$, por otra parte, hay en el mundo demasiada gente para que el olvido sea posible. Siempre quedará un hombre vivo para contar la historia. En consecuencia, nada podrá ser jamás —prácticamente inútil—, por lo menos a la larga (p. 142).

Es absurdo pensar el olvido como decreto funcional para la cohesión; empero, si cumple un papel importante en la medida de no perder memoria de un acontecimiento, pero sí perder responsabilidad sobre este, la misma Arendt (2007) señala que donde todos son culpables nadie es responsable. De tal forma, se diseñan dispositivos de perdón que, muchas veces, encierran una exculpación de las responsabilidades en nombre de «culpas colectivas».

Entonces, la participación política del Estado se ve condicionada por su propio accionar y su legado; y procura no solo mantener una estabilidad social, sino proyectar una cohesión que identifique a sus ciudadanos con sus amigos y ante sus enemigos, pues estos últimos se nombran y particularizan de manera clara. 
De ahí que las campañas mediáticas en sociedades como la colombiana encaren una emotividad bastante tendenciosa ante personas particulares, las cuales representan un peligro contra los derechos básicos del ciudadano, normalmente delincuentes que se sobredimensionan (golpeadores de niños, mujeres, psicópatas en la calle que tiran ácido a los transeúntes, miembros de barras de futbol, entre otros) no por ser exentos de culpa, ni por ser acciones menores, sino porque nunca se le da un cubrimiento mínimamente semejante ante el caso de personas involucradas con la institucionalidad.

Tal es el caso del coronel retirado del Ejército Alirio Antonio Urueña que se mencionó anteriormente por su participación en el caso Trujillo o el teniente de la policía Fernando Berrío. Estos fueron condenados como responsables de la masacre y ambos salieron por cuestiones técnicas. El Estado reconoció que dentro de la masacre existió una sevicia manifiesta en torturas, mutilación de miembros mientras las personas se encontraban vivas, desaparición forzada y una persecución sistemática contra la población.

En el caso de Trujillo, al igual que en poblaciones cercanas como Bolívar y Riofrío, la responsabilidad de lo sucedido recayó sobre paramilitares con la ayuda de la Policía y el Ejército, de ahí que el expresidente Ernesto Samper en 1997 pidiera disculpas públicas por lo sucedido y aceptara la culpa plena del Estado en 34 de las 342 víctimas.

Tal relación no es nueva y las denuncias sobre ello tampoco. En el año 2007 la Corte Suprema de Justicia falló e indicó que el paramilitarismo no actuaba contra el Estado, sino que era su cómplice; en el informe de Amnistía Internacional del año 2008 dice: «... los grupos paramilitares siguen operando y cometiendo graves violaciones de derechos humanos, a pesar de su supuesta desmovilización, y siguen contando con el apoyo o la aquiescencia de algunos sectores de las fuerzas de seguridad» (p. $15)$.

Así mismo, como lo señala el mismo documento, la responsabilidad estatal es mayor cuando en los últimos diez años se incrementó el nivel de persecución contra la oposición, los sindicalistas y las ONG 
de derechos humanos, entre ellas a la misma Amnistía Internacional. Esta situación, en buena medida, es gracias a las declaraciones del expresidente Uribe ${ }^{10}$, las cuales dejan leer un mensaje político bastante estigmatizador y peligroso para aquellos que estaban en contra de su gobierno. Una muestra clara de la intención homogeneizante de aquello que Arendt (2007) diferenció entre una dictadura y un gobierno totalitario.

Por lo menos, la fractura que no permite saldos parciales de las responsabilidades, en este tipo de procesos, está relacionada con la mixtura de lo jurídico y lo emotivo, la cual es fuertemente impulsada por el Estado a través de los medios, los llamados a manifestarse públicamente contra violadores o por psicópatas al acecho. Situación que admite un mecanismo de focalización, el cual disuade una realidad donde indicadores de violencias fuertes, ejercidos o no por el Estado, son opacados bajo figuras puntuales y con rostro de «maldad».

El vínculo entre la consciencia moral y la acción jurídica se ve reflejado en la omisión de la ciudadanía en el contexto colombiano ante ejemplos concretos como el hambre extrema o las muertes por inanición, entre los cuales varios casos fueron registrados en sectores del departamento del Chocó; casos excluidos de la agenda pública del país, a diferencia de marchas y manifestaciones sociales para apoyar la cadena perpetua contra violadores o los instigadores con ácido ${ }^{11}$.

10 «En septiembre de 2003, el presidente Uribe describió públicamente a algunos críticos del gobierno como "politiqueros al servicio del terrorismo [...]. Cada vez que en Colombia aparece una política de seguridad para derrotar el terrorismo, cuando los terroristas empiezan a sentirse débiles, inmediatamente envían a sus voceros a que hablen de derechos humanos". En junio de 2004, en un discurso pronunciado ante miembros de la policía colombiana, el presidente Uribe afirmó erróneamente que Amnistía Internacional "no condena las violaciones al derecho internacional humanitario cometidas por los grupos guerrilleros" y "legitima el terrorismo".

En un discurso pronunciado en julio de 2007, el presidente Uribe afirmó: "Ahora la estrategia guerrillera es otra: cada vez que se le da una baja a la guerrilla, ahí mismo moviliza a sus corifeos en el país y en el extranjero para decir que fue una ejecución extrajudicial".

En un discurso pronunciado en mayo de 2008, el presidente Uribe, refiriéndose al entonces defensor de los derechos humanos Iván Cepeda, que había recibido amenazas de muerte, afirmó que "antes de compadecerse por las lágrimas de cocodrilo de estos farsantes de los derechos humanos", los miembros de la comunidad internacional deberían visitar Colombia para ver lo que realmente ocurre en el país» (Amnistía Internacional, 2008, p. 19).

11 Es indispensable insistir en que no se parte por desconocer la delicadeza y la importancia de condenar este tipo de acciones criminales, lo que se objeta es la manipulación mediática hecha de ello para que otro tipo de actos, igual de delicados, sean omitidos del relato popular. 
La consciencia moral de un pueblo no se mide por tipificaciones en cuanto a la dimensión de los delitos, pero debe representar pilares éticos donde la condición humana no se límite a descansar la responsabilidad ciudadana en el hacer bien.

El deber del Estado se ve reflejado en saber tomar esta distancia moral con la necesidad jurídica de establecer procesos, por el bien colectivo, sin desestimar el lugar de la consciencia moral, el cual se encuentra enquistado en la justicia. En este sentido, se debe entender la responsabilidad y la culpabilidad de un delito que atenta no solo contra un sujeto, sino contra el bien común. Arendt (2007) destacaba al respecto:

Una suerte que exista en la sociedad una institución en la que es prácticamente imposible eludir las responsabilidades personales, en la que todas las justificaciones de naturaleza vaga y abstracta — desde el Zeitgeist, hasta complejo de Edipose derrumban, en que no se juzgan sistemas, tendencias ni pecados originales, sino hombres de carne y hueso como tú y yo, cuyos actos son desde luego, actos humanos [sic] pero comparecen ante un tribunal porque han infringido alguna ley cuyo mantenimiento consideramos esencial para la integridad de nuestra común humanidad (p. 52).

En medio de las continuas guerras entre Estados o al interior de estos en el discurrir histórico de la humanidad, el fin de la Segunda Guerra Mundial y todo el espesor posconflicto que se desató a mediados del siglo Xx generó lecturas como la enunciada por Arendt donde se trae a la escena pública la importancia de pensar el pasado y su cohesión con el presente desde las responsabilidades que, sobre este, las personas y los Estados debían asumir.

La esfera ética no es un aditivo en la formación de la ciudadanía, sino un epígono para las bases del bien común. La consciencia moral implica preguntas subjetivas donde el interrogante implica una introspección que presuma una consecuencia individual ante lo que se considere correcto o incorrecto. La responsabilidad política atañe no 
solo al perpetrador de una acción, sino al cómplice activo o pasivo de esta; así, la naturaleza política del ciudadano implica entonces un deber carente de exoneración en las dinámicas colectivas, pues el silencio pierde su valor de neutralidad en un contexto social como el trabajado.

Se exige una institucionalidad que reconozca sus errores con el pasado y los asuma como tal, tanto en lo colectivo como en lo particular de una condena. De igual forma, se apela a una figura que garantice, como primera medida, la no repetición, pues aquí el fracaso del Estado colombiano - en el caso de Trujillo- es bastante significativo; y la reparación en especial desde el juicio a los responsables como mecanismo de recuperación de aquella identidad masacrada y desaparecida, más de veinte años después con ningún condenado, da cuenta de una impunidad y una ineficacia en los procesos penales, lo cual deja un vacío no solo con la ley, sino con la legitimidad del Estado como garante de esta.

Finalmente, se puede concluir un enunciado de Jaspers (1998) en su intento por diferenciar responsabilidades, culpas, defensas, crímenes, entre otros, frente al caso de la sociedad y el Estado alemán:

Un estado [sic] que, desde un principio en el propio país, ha lesionado en lo fundamental el derecho natural y los derechos humanos y que, más tarde en el curso de la guerra, ha pisoteado en el exterior los derechos humanos y el derecho internacional público, no puede reclamar en beneficio suyo el reconocimiento de eso que él no ha reconocido (p. 63).

Enunciado que retrata, a manera casi de lamentable analogía, lo señalado respecto al lugar y el papel del Estado colombiano en el caso Trujillo y en cientos de hechos en la historia política del país. 


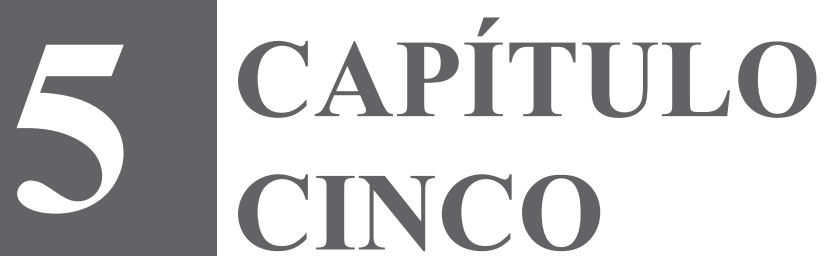




\section{Nociones de la biopolítica de Foucault, rasgos coincidentes en la comprensión de una tragedia}

En los siglos XVI-XVII, vemos crecer en el ejército, los colegios, los talleres, las escuelas, toda una domesticación del cuerpo, [sic] que es la domesticación del cuerpo útil. Se ponen a punto nuevos procedimientos de vigilancia, de control, de distribución en el espacio, etcétera. Hay toda una investidura del cuerpo por mecánicas de poder que procuran hacerlo a la vez dócil y útil. Hay una nueva anatomía del cuerpo (Foucault, 2004, p. 186).

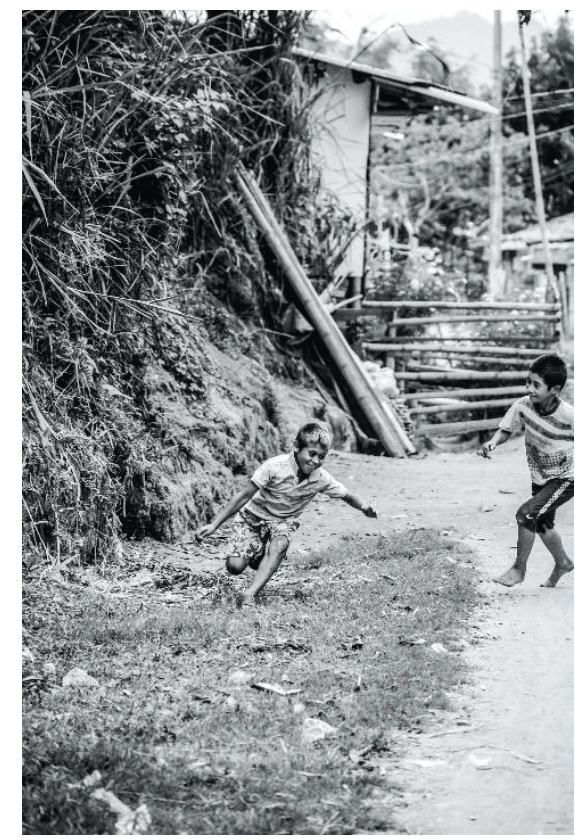

Fotografía por Jhon Hurtado 
La tesis clásica de agente-estructura en la sociología permite, sin caer en sincretismos académicos, pensar en lo que, desde la apuesta política y económica de un país, se proyecta sobre una población a partir de su razón de Estado. Los hábitos y las formas de ejercer la ciudadanía se ven atravesados por la agenda pública que se trabaje en ese momento.

La particularidad del Estado colombiano no permite asir con claridad un proyecto de nación unificado, si bien existen prácticas como la apertura económica, la venta de recursos naturales y la venta del patrimonio económico nacional representado en las empresas públicas y en la privatización en diferentes escalas. Estas dinámicas tienen en su interior y en distintos niveles múltiples actores involucrados, a saber, afectados y víctimas, cómplices y victimarios, y beneficiarios directos e indirectos; lo que no habla de una bitácora política de Estado, pues sería más bien un prisma político y económico inaprehensible en un solo caso.

De esta forma, se enfrentan realidades sociales diversas en cada región, unas con mayor margen de participación en cuanto a su implementación u oposición como el caso de Bogotá con las manifestaciones públicas por la venta de la Empresa de Telecomunicaciones de Bogotá (ETB) ${ }^{12}$ y otras organizaciones; simplemente bajo el sometimiento por la fuerza de proyectos, tales como la megaminería, el cultivo de palma, el narcotráfico y el contrabando.

Siendo estos últimos casos los que se presentan en las zonas afectadas por la desaparición forzada en el país; de esta forma, el accionar, en especial de grupos paramilitares, ha permitido que regiones completas hayan estado sometidas históricamente a los intereses económicos y políticos de terratenientes, latifundistas o empresas con capital

12 La Empresa de Telecomunicaciones de Bogotá (ETB) fue enajenada del control del distrito de la ciudad de Bogotá en mayo del 2021 por el concejo de dicha ciudad. Esta situación ocasiono un número amplio de manifestaciones no solo en este territorio, sino en todo el país, pues las personas se oponían a la venta de uno de los recursos patrimoniales más importante de Colombia. 
extranjero $^{13}$. Así, la desaparición forzada, el desplazamiento y las masacres son instrumentos que se insertan en un lenguaje que va más allá de la guerra y busca construir un disciplinamiento de los hábitos del ciudadano a partir del miedo.

Este capítulo procura cerrar la lectura a partir del abordaje de las características de la razón o razones del Estado y su papel en la construcción de un cuerpo individual y social desde su control y sometimiento; en un ejercicio que se asemeja a la biopolítica de Foucault, pero que por la naturaleza económica, social y política del caso colombiano tiene bastantes diferencias, lo que no posibilita utilizar esta como una categoría leída desde lo que el autor plantea concretamente. No obstante, este término ayuda a entender algunos elementos que permiten analizar la naturaleza de los fenómenos de poder, y la dominación con el cuerpo y sobre este, inclusive, más allá de la vida biológica como sucede con la desaparición forzada.

Se inicia desde algunos esbozos de lo que sería la dimensión económica; pasando por el ejercicio de control de la vida y la administración de la muerte por parte de los victimarios; hasta finalizar enunciando algunas de las distancias entre un proyecto de Estado y un comportamiento en el nombre del gobierno, pero ejecutando algunos actores miembros del mismo.

\subsection{Un primer tránsito}

Para Colombia, la idea de un antecedente sociopolítico de la desaparición forzada se ha desarrollado en este trabajo desde la noción de marcos sociales esbozados por Halbwachs (2004). Esta referencia conceptual, como se planteó en capítulos atrás, interviene dinámicamente en la comprensión de los efectos históricos de dicha

13 En el año 2012, la Corte Suprema de los Estados Unidos condeno a la multinacional Chiquita Brands por sus vínculos con paramilitarismo en Colombia. El Departamento de Justicia de ese país estima que, entre 1997 y 2004, se llegó a pagar por parte de la empresa 1.7 millones de dólares, lo que acarreó como consecuencia, al reconocer tal delito, pagar una multa 25 millones de dólares a dicha institución y, de esta forma, evitar la cárcel para los involucrados. Paradójicamente, cuando se presenta la condena en ese país, el fiscal 33, especializado de Medellín, quien adelantaba una investigación por los mismos hechos en Colombia decide precluir el caso. 
tragedia; sin embargo, de los diversos criterios que estructuran los marcos sociales, es necesario hacer énfasis, de manera general, en el acontecer histórico del desarrollo económico, gracias a su importancia para las construcciones sociales desde y al margen de lo institucional. Si bien no se pueden limitar las interacciones, los comportamientos y las representaciones que tiene una sociedad desde esta característica, si es claro que el modelaje económico de un país, tanto desde lo legal como desde lo ilegal, intercede en la noción de mundo, de realidad y de socialización que se tiene desde afuera y desde adentro del territorio.

De esta forma, dar un recorrido genérico al respecto implica pensar los legados que, paulatinamente, se han adherido en el cuerpo social de una nación por diferentes vías.

Problematizar inicialmente un precedente económico tiene múltiples implicaciones y en el caso de países de América Latina aún más, pues la simbiosis entre modelos impuestos e improntas criollas de cada caso ${ }^{14}$ requiere reconocer la plasticidad de apuestas como las que subyacen en el modelo liberal y neoliberal, a nivel mundial, donde las derivas propias son resultados de la propia diversidad y versatilidad de los escenarios socioculturales de cada región.

El prisma económico en el desarrollo político de un país abarca diversas capas y, por ende, múltiples escenarios. En este trabajo se realizó tan solo la referencia a uno de ellos, el cual tiene que ver con el cuerpo y su dispositivo social. Todo ello al enfocar la mirada en el mensaje que, sobre este, desde este y con este se establece con prácticas como la desaparición forzada.

El cuerpo es un antecedente no exento en el diagrama de poder cuando existe un proyecto económico. En tal sentido, la biopolítica definida por Foucault (2004) permite inscribir un modelo económico y racionaliza este sobre el dominio del cuerpo al decir:

14 Un ejemplo clásico al respecto lo presenta Chile con la implementación de la apuesta económica de los denominados «Chicago Boys», los cuales, de la mano de Milton Friedman y Arnold Harberger, apelan a una política de privatización por encima del Estado. Dicha propuesta tuvo la oportunidad de implementarse en el marco de la dictadura de Augusto Pinochet. 
El capitalismo, que se desenvuelve a fines del siglo xvIII y comienzos del XIX, socializó un primer objeto, que fue el cuerpo, en función de la fuerza productiva, de la fuerza laboral. El control de la sociedad sobre los individuos no se opera simplemente por la conciencia o por la ideología [sic] sino que se ejerce en el cuerpo, con el cuerpo. Para la sociedad capitalista lo importante era lo biológico, lo somático, lo corporal antes que nada (p. 87).

Este escenario implica entender que es más que pura actividad biológica donde se debe retomar la simbiosis global anteriormente enunciada, pero desde los dos rasgos vistos de formas independientes. Por un lado, los modelos económicos imperantes a nivel mundial y, por otro, las prácticas locales de estos donde, en el primero, se proyecta el cálculo económico, la racionalidad, la proyección estructural de un modelo de desarrollo y; en el segundo, su sedimentación en escenarios propios, experiencias concretas y maneras de hacerlo posible desde perspectivas locales. De esta forma, es importante pensar una biopolítica donde el cuerpo se desarrolla con nuevas libertades del orden social en continuo progreso $\mathrm{y}$, donde también, se diseña y se interviene políticamente para que deba afirmar tal proyecto en comportamientos y expresiones sociales permitidas y controladas por el Estado.

Por tanto, la lógica obliga al ejercicio de control al tomar distancia o reprimir las resistencias u oposiciones que pueda expresarse en contra de la racionalidad que guía el proyecto económico. Siguiendo a Foucault, lo más importante es mantener sobre el cuerpo su control en pro de la razón del Estado.

Desde un caso concreto como el colombiano, el cuerpo social intervenido políticamente presenta variedad de manifestaciones en la actualidad. Pensar los posibles rasgos y antecedentes de estos, los cuales expresan el control social sobre el cuerpo, requiere tomar solo una veta de análisis, la cual es la desaparición forzada. De antemano se aclara que en este fenómeno no se presenta un ejercicio pleno de biopolítica en términos de Foucault, pero tal concepto sí ayuda a entender varias 
características de la relación poder y dominación sobre el cuerpo del desaparecido y el cuerpo de la comunidad desde algunos de los criterios usados por el autor para trabajar dicha categoría.

La primera característica, en el caso del cuerpo que no está, es la de una vida que ha sido suspendida como agente social presente, una especie de perpetuidad social o idea fantasmal de ausencia-presencia hasta que no regrese de alguna manera para su familia, la cual siempre está ahí, pero no tiene vida material. El cuerpo del desaparecido es arrebatado del cuerpo de la comunidad y, así, asume, más allá de la corporeidad, un estatuto político como mensaje de control sobre la población dirigido desde el victimario.

La desaparición de la persona atraviesa tres registros determinados por Lacan (1981) en la vida psíquica: lo real, lo imaginario y lo simbólico; sin embargo, a pesar de lo indisoluble de los vínculos entre un registro con otro, en lo político el enfoque se analiza en los dos últimos.

Lo imaginario, a partir de la ausencia física, pues se constituye una imagen que se presenta ante el sujeto, pero que no se puede nombrar, dado que no se inscribe en el orden del lenguaje y es desbordado por el mismo. No se sabe cómo apalabrar esa sensación de vacío, imagen del desaparecido-ausente que, arrebatado de corporeidad, hace más fuerte su lugar en la presencia del registro imaginario, porque esa es precisamente la intención del mensaje: no el eliminar a alguien, sino condicionar su falta corpórea de un espacio que ya no ocupa. No «alguien», sino «algo»; un objeto miedo que deriva en control. Se sustituye dicha ausencia por la figura de un imaginario estimulado por el desaparecido.

En el registro de lo simbólico, se entiende la presencia de un mensaje que va más allá de la víctima y donde los receptores son, precisamente, los miembros de la comunidad que conviven con la angustia de la suerte del desaparecido y la zozobra de la repetición. Aquí se inscribe el lenguaje de la violencia, el cual es estructurado por las narraciones colectivas y particulares de la ausencia del cuerpo, el miedo a la repetición, la espera del retorno y la impotencia de la búsqueda. 
El símbolo es, por un lado, el mensaje implícito de la pérdida, pues los entrevistados decían: «sabemos que está muerto, que nunca aparecerá» (Virginia, comunicación personal, julio de 2014); una aceptación ambigua de su muerte, dado que siempre terminaban diciendo, posterior a estas afirmaciones, que igual lo esperan. Por otro lado, el mensaje explícito del «posible» retorno no del desaparecido, sino de la acción del verdugo o la repetición del acto, lo cual, en muchos, casos no fue solo amenaza; de esta forma, se inscribe una marca en el cuerpo social desde la fragmentación de un cuerpo individual y la instauración colectiva de un mensaje grabado con dolor.

Inevitablemente, este relato coincide con el ejercicio biopolítico, especialmente en el caso de las dictaduras, pues se da un puente entre el diseño de control sobre el otro, el cual es pensado históricamente como mecanismo de poder, y la manifestación de violencia extrema usada de manera pública como instrumento de dominación; esta situación en hechos como la Segunda Guerra Mundial con personajes como Hitler y su decreto de Noche y Niebla, al cual se hizo alusión en capítulos anteriores. No obstante, es importante anotar que esta práctica posee su versión reactualizada en una especie de contextualización de la tortura y las prácticas de sometimiento en los crímenes perpetrados por los ejecutores de la Operación Condor ${ }^{15}$ en el Cono Sur a mediados del siglo XX. en el Cono Sur a mediados del siglo XX.

El discurrir histórico de este práctica como una política dentro de la biopolítica de algunos territorios en Suramérica, con o sin dictaduras, teje diversas herramientas que intervienen en el momento de las elaboraciones realizadas por las víctimas frente a la desaparición forzada, tanto de forma individual como de manera colectiva; un legado histórico que marca una huella, la cual se convierte en el acervo de un territorio concreto, a saber, su cultivo inicial que condiciona las decisiones tomadas en el momento inmediato en el que se vive o se padece una situación de esta naturaleza.

15 Operación coordinada entre los regímenes dictatoriales del Cono Sur con el apoyo de la Agencia Central de Inteligencia (CIA) y respaldado por intervalos de los países que no tenían dictadura directa como el caso de Colombia. Una de sus prácticas más comunes fue precisamente la desaparición forzada, donde Colombia instauro esta como una política más que para la cooperación continental, para la intimidación y el control de sus disidentes al interior del país. 
De esta forma, desaparecer puede ser una práctica común en una época como la vivida en el último tercio del siglo xx, pero el efecto de esta práctica es diferente, por ejemplo en el caso argentino en relación con el caso hondureño o el colombiano.

Tales derivas dependen de los acumulados locales a lo que Foucault (2004), en el nacimiento de la biopolítica, señala como la importancia de pensar la historia de América Latina no como una memoria monolítica, sino como una historia de los conflictos y de los dispositivos de control con prácticas de dominación similares, pero con desarrollos propios en cada sitio. Como la práctica elemental más común se destaca la coacción física; no obstante, esta no es la única, pues la coacción simbólica es más fuerte y puede tener efectos más prolongados en el cuerpo, pero sí como una práctica con intencionalidades propias, dado el lenguaje y la memoria que caracterizan una zona geográfica y políticamente distinta de otra.

El territorio, al variar sus dinámicas por la memoria social que lo contiene, traduce el papel de distintos actores por la voz o el lenguaje que este emite en cada una de sus prácticas. La contraposición señalada por Foucault (2010) entre el «acheronte de movebo» ${ }^{16}$, la capacidad de tomar decisiones que impliquen un papel activo del Estado; y el «quieta non movere» ${ }^{17}$ de Walpole siguiendo a Foucault no intervenir en lo que está tranquilo así esté mal, permiten usar esta metáfora desde las dos definiciones en zonas de conflicto en el caso colombiano, lo cual evidencia, desde ello, la comprensión del doble rol que cumple el Estado en lugares de mayor vulnerabilidad social.

Por un lado, «quieta non moveré», es decir, la notable ausencia del Estado durante muchos años y, con esta, la perdida de garantías que constitucionalmente debe brindar no solo en términos de seguridad, sino en términos de derechos fundamentales como la salud, el trabajo y la educación. Esta situación se puede ilustrar en el bajo nivel de desarrollo de las zonas afectadas por la violencia, la poca infraestructura

16 «... si no puedo doblegar a los dioses supremos, moveré el Aqueronte» (Foucault, 2010, p. $195)$.

$17 \ll . .$. no hay que tocar lo que está tranquilo» (Foucault, 2010, p.195). 
y las deficiencias en la prestación de servicios. Un ejemplo histórico lo brinda la información del Departamento Nacional de Planeación veinte años atrás, la cual dice:

La Costa Caribe, una de las regiones con el mayor nivel de violencia en el país, también tiene uno de los índices más altos de pobreza. El 52 por ciento de su población, cerca de 3,5 [sic] millones de habitantes son pobres. [...] De acuerdo con una evaluación del Departamento Nacional de Planeación en 50 de los 175 municipios de la región el 75 por ciento de la gente es pobre, mientras que en 34 municipios los niveles de miseria son superiores al 50 por ciento. La miseria es el doble a la del promedio nacional siendo particularmente dramática en la Guajira, Córdoba y Sucre. Miles de familias sobreviven sin agua, acueducto, alcantarillado o viviendas adecuadas y tiene un nivel de ingresos que no le permiten comprar los alimentos necesarios (Redacción El Tiempo, 1997).

Los datos casi diez años después, para el 2006, ratifican la misma escena, pues sigue siendo el campo la zona más azotada por la violencia social en el país, el cual, por ejemplo, continúa representando la tasa más alta en indicadores como la pobreza, «De acuerdo al informe, la pobreza rural del país pasó en el último año del 67,5 [sic] al 68,2 [sic] por ciento. En esa situación se encuentran ocho millones de campesinos de los cuales tres millones son indigentes» (Caracol Radio, 2006).

Sin desconocer factores de vulnerabilidad producto de elementos como la crisis del café, los megaproyectos, el monopolio de cultivos, la ganadería, entre otros, es la violencia armada uno de los ejes primarios que se vincula con los elementos anteriores a la crisis del campo y su posterior efecto hacia la ciudad. Situación que genera consecuencias tales como desplazamientos, masacres y desapariciones; y deja en evidencia un sinnúmero de actores sociales-victimarios. No obstante, se destaca como factor primario la falta de intervención del Estado en las garantías básicas de estas comunidades. 
En conclusión, el aparente no hacer es intencional, el Estado termina en este su supuesto no moverse al realizar una acción política que permite el desarrollo del control territorial por parte de grupos de autodefensas o paramilitares, los cuales, en muchos casos, son nutridos o protegidos por dicha institución.

Contrario a esta situación, se presenta, en los últimos años, el «acheronte de movebo», un alto nivel de intervención del Estado, en especial desde el terreno militar, el cual inicia con el Plan Colombia en el marco del gobierno de Andrés Pastrana y llega a un nivel de mayor agudización en los dos gobiernos presidenciales de Álvaro Uribe Vélez, sujeto que focalizó su accionar frente al tema de la seguridad y el movimiento del acheronte, esto es, el aumento de pie de fuerza en zonas de conflicto, infraestructura bélica incrustada al interior de los pueblos y en sus cabeceras, y la militarización de zonas de tensión, lo cual trajo como consecuencia una ola muy fuerte de desplazamiento forzado, dado el nivel de agudeza que alcanzaron las confrontaciones, tal como se señaló en el «Capítulo dos» al mencionar el 2002 como el año de mayor número de desaparecidos en la historia del país y el año 2003 y 2004 como los momentos de mayor nivel de homicidios, desplazamientos y secuestros (RUV, ).

El impacto en la estrategia de Gobierno implica una ambivalencia con la población de estas zonas hasta el punto de que comunidades, como las indígenas nasa en el Cauca ${ }^{18}$, insten a que dicho Gobierno salga de sus territorios, ya que, según ellos, es precisamente el desmesurado aumento de intervención de fuerza pública lo que ha incrementado la crisis. Todo ello debido al aumento de las confrontaciones donde, además, los resultados en cuanto a seguridad son un fracaso.

18 A mediados del 2012 los nasa, en el Cauca, iniciaron una campaña de desalojo de la fuerza pública y la guerrilla de su territorio. La guardia indígena se comportó como una resistencia a la política de Estado, un cuerpo que se fragmentó por reconocer en el Gobierno el causante de la falta de protección y, también, el responsable en el aumento de confrontaciones armadas con grupos ilegales, lo que trajo como consecuencia mayores niveles de desplazamiento, desaparición y homicidio. La razón de Estado en un marco normativo legal se presenta como irracional por parte de algunos miembros que integran la biopolítica del territorio en esta zona. 
Los datos frente a la inversión del gasto público respecto al tema de seguridad nacional son bastante claros al respecto:

Por primera vez el presupuesto para defensa y seguridad superó al de educación. El primero será del 14,2\% [sic] del Producto Interno Bruto (PIB), mientras el segundo fue establecido en 13,9\% [sic] del PIB. En la última década la inversión en defensa creció, en promedio, al 3,2\% [sic] anual en términos reales, mientras que la inversión del Estado en educación se acerca al 4,7\% [sic] del PIB (El Espectador, 2009). ${ }^{19}$

El aumento desmesurado de inversión en las fuerzas armadas corresponde perfectamente con la disminución de los rubros dedicados a temas como la educación y la salud. Esta problemática, si bien se denuncia con mayor fuerza en las ciudades principales, es una situación generalizada en todo el país, pues es importante destacar la incidencia de estos hechos en los sectores más vulnerables afectados por el conflicto armado.

En ese sentido, el arte de gobernar como mecanismo de uso de la soberanía política de un país implica entender las razones de Estado que movilizan cada decisión, sea por acción o por omisión. En el caso colombiano es fundamental, como lo señala Foucault, en cuanto a la teoría de razón de Estado, es decir, pensar un método de análisis desde y para las relaciones de poder, pero, específicamente, para este contexto desde un abordaje distinto, a saber, con el uso de la racionalidad biopolítica sobre el otro como dispositivo de control implementado en las regiones, hacia las razones de Estado estructurales para un proyecto económico y de la práctica local hacia el proyecto nacional, para así comprender, de manera particular, las zonas afectadas por la desaparición forzada.

Estas zonas de conflicto producen un sometimiento racionalizado sobre el cuerpo biológico y social y, a su vez, están inscritas desde el proyecto neoliberal; situación que brinda un marco no solo para la

19 Periódico el Espectador, Bogotá 21 de octubre 2009 
historia política del país, sino para la historia política del sujeto que vive y representa esa memoria latente en su singularidad, pero intervenido por una región específica.

Como lo señala Barrera (2011) «... durante la modernidad se actuó de manera deliberada sobre el cuerpo» (p. 122), precepto que condiciona la corporeidad a las relaciones económicas y políticas, y expresa su materialidad en formas de control amplias como dispositivo de sometimiento, tal como sucede con la desaparición forzada, el asesinato selectivo, las masacres y el desplazamiento.

Sin embargo, la finalidad que sería desde Foucault (2010) la intencionalidad en procura de una sociedad disciplinar se enfrenta a la clásica apuesta política entre el centralismo del Estado y la autonomía de las regiones; si bien esta dualidad enfrentó la apuesta gubernamental del desarrollo de casi todos los países de América Latina, se conoce más desde la producción económica y tiene su propio relato en los mecanismos de control y normativización del cuerpo individual y social, ya que las mencionadas formas de disciplinarlo no son homogéneas ni en su proceder, ni en su impacto, ni tampoco en su intencionalidad.

En el caso de zonas de fuerte presencia guerrillera como el Catatumbo, el cuerpo del opositor del Estado es perseguido, eliminado y exhibido; en la agenda pública estos son trofeos humanos que le quitan al otro su estatuto subjetivo y lo regulan como «bajas» mientras los propios (aliados a dicha institucionalidad) los asumen como «perdidas» $\mathrm{y}$ «héroes caídos en combate», lo que implica una racionalidad del Estado desde la normativización social por medio del sometimiento del «terrorista», el cual no puede otorgársele, bajo ningún criterio, la lógica de contendor y su cuerpo no puede ser objeto de reconocimiento.

En zonas de alta presencia paramilitar como el Magdalena Medio, el Estado tiene distintas alianzas que no necesariamente buscan fortalecer su razón; quizás por eso no se puede hablar plenamente de la «biopolítica» en términos foucaultianos en el caso colombiano más allá 
de lo mencionado, es decir, valerse de algunos de sus componentes para entender este escenario.

Los vínculos con los paramilitares van en su mayoría en dos direcciones; primero, desde la razón del modelo neoliberal a través de la vía libre para la llegada de inversión extranjera o el fortalecimiento de capital privado nacional; hasta ahí se podría pensar el concepto de Foucault (2010), pues este inscribe el cuerpo en un sistema de regulación normativo en pos de una producción económica:

El cuerpo humano es, como sabemos, una fuerza de producción, pero el cuerpo no existe tal cual, como un artículo biológico o como un material. El cuerpo humano existe en y a través de un sistema político. El poder político proporciona cierto espacio al individuo: un espacio donde comportarse, donde adoptar una postura particular, sentarse de una determinada forma o trabajar continuamente (p. 42).

Segundo, la complicidad con terratenientes y narcotraficantes donde es claro que no existe una política de Estado que pretenda esta situación, pero sí una institucionalidad contaminada con actores que se lucran de dicha dinámica. Aunque no es la estructura institucional la que inscribe esta práctica, sí son algunos miembros que lo representan; desde militares hasta políticos en distintos cargos la ejecutan. En este caso no aplica el concepto de «biopolítica» de Foucault; sin embargo, a través de este autor se permiten evidenciar micropoderes que, en el nombre del Estado, ejercen control y sometimiento, ya que los pobladores no ven un intermediario, sino un miembro de la fuerza pública cómpliceresponsable de prácticas como masacres, homicidios o desapariciones forzadas.

Ambas direcciones no se ubican en razones de Estado y en el marco de un proyecto económico, pero sí redundan en el método de aplicabilidad del disciplinamiento sobre el cuerpo, pues el paramilitar tiene la libertad de estar al margen de las reglas del combate y del 
derecho internacional humanitario; por ello, el Estado, en algunos casos como en el genocidio de la UP ${ }^{20}$ en los noventa, se vale de estos grupos para llevar a cabo sus actividades.

La desaparición forzada es, sin lugar a dudas, un dispositivo distintivo de dichos grupos paramilitares, el cual tiene un mensaje que, como se ha mencionado, no va dirigido solo sobre el cuerpo de quien se decide desaparecer, sino que logra un fuerte control sobre el cuerpo social, sobre el comportamiento individual, y sobre las normas entre lo permitido y lo castigado en esos territorios, es decir, buena parte de la consecuencia del ejercicio de la biopolítica.

\subsection{Acción, omisión, intención}

El rol dicotómico, entre intervenir y abandonar sectores y actores en el país, no es producto exclusivo del nivel de agudización del conflicto armado en Colombia, sino de la intención o la razón de este para hacerlo en regiones con o sin este mismo fenómeno. Las preguntas que sugieren esto realmente se establecen en dos momentos: primero, ¿cuál es la apuesta real del modelo de desarrollo que los sectores productivos quieren aplicar para el país desde lo central o desde lo local?; segundo, si la intención fuese la aplicación del modelo económico neoliberal, ¿cómo entender la intención, el alcance y el impacto del mensaje enviado por medio de la desaparición forzada?

Sin lugar a dudas, la primera pregunta implica un rastreo histórico y documental bastante complejo, gracias a los conflictos de poder que se desarrollan con sectores tradicionales a nivel nacional, los cuales se confunden con los micropoderes regionales. Prácticas como el narcotráfico, la minería, la hegemonía de la tierra por grandes

20 La Unión Patriótica (UP) fue un grupo político de izquierda fundado en 1995 con presencia de algunos militantes de las FARC-EP y diversos activistas sociales, el cual ingresó al escenario público de una forma bastante exitosa a mediados de la década del ochenta y logró tener senadores, representantes a la cámara y diputados en todo el país; lo cual les permitió presentarse en los comicios presidenciales y, por tanto, constituirse como una alternativa posible de poder. La respuesta gubernamental a este grupo fue su genocidio de la mano de grupos paramilitares, pues se calcula que fueron asesinadas unas cinco mil personas y que muchos de los sobrevivientes huyeron del país. 
terratenientes y las más delicadas relaciones entre aquellos que fusionan el negocio de la tierra (el ganado y las drogas) logran establecer sistemas institucionalizados en la población no necesariamente gubernamentales, pero sí normativos, autosuficientes e independientes de una razón de Estado unificada donde el control, en ciertos territorios, es integral por estos actores y donde el grado de injerencia del Estado es mínimo o cooptado por negociaciones regionales entre aquellos representantes con políticos y/o militares reconocidos en la zona. El ejemplo más común es el de la corrupción a través del desvío del recurso público en entidades estatales que hacen presencia en zonas violentas, así como la convivencia de grupos de autodefensas y brigadas del Ejército que protegen sus lugares de acción.

Si bien la esencia de la segunda pregunta tiene que ver con varios de los capítulos desarrollados en esta investigación, en este caso es pertinente pensar en el reconocimiento de algunos de los elementos que caracterizan el entorno sociopolítico, de miembros de estas comunidades, desde la perspectiva del control y el dispositivo de sometimiento sobre el cuerpo como elemento mediador para un proyecto económico.

No obstante, se aclara que si bien la condición histórica del contexto es un marco social de intervención en la vida cotidiana del sujeto, la voz de las víctimas tiene una impronta propia; las palabras les permiten ser escuchadas, pero no como un único marco, sino como personas que, en momentos de posacuerdos y reintegraciones, son el aprendizaje ensordecedor de la huella de un país con múltiples relatos, el cual, gracias a la naturaleza de «los territorios», produce como resultado diversas memorias de lo que se ha sido, de lo que son y de lo que podrían llegar a ser.

\subsection{Biopolítica, el resultado de comunidades históricas más allá de su aparición como víctimas}

La denuncia y la internacionalización de los conflictos ha llevado a un nuevo boom de la condición de víctima; cientos de oenegés trabajan en su nombre con intenciones diversas, pues esta tiene inclusive grados y niveles para su atención, y su importancia pasa de ser un punto de prestigio hasta convertirse en una etiqueta de muerte. 
En el caso colombiano, estas situaciones se ven con bastante asiduidad gracias al nivel continuo de violencia no solo política, sino de género, de familia, entre otras donde es indispensable pensar esta definición más allá de un momento o una situación concreta. En el caso de la desaparición de un familiar, un amigo o un conocido, no existe una emergencia completamente nueva de la condición de víctima; de hecho, antes del acontecimiento, muchas lo son, tal como se desarrolló en la metodología de este trabajo.

Esta situación se debe a que el drama no se puede pensar sin antecedentes, no es una experiencia fundamentada sobre la nada del sujeto $\mathrm{y}$, más bien, es una cadena de acontecimientos previos que alimentan un marco social, el cual genera una reacción particular de lo sucedido y expresa, en la población, una memoria que tejió un dispositivo social de la muerte desde su experiencia histórica producto de un entorno que la definió, la caracterizó y la representó a lo largo de los años.

La relación entre ese marco social previo, el cual es amparado bajo los visos del ejercicio del control biopolítico, dejan una huella y un trazo cultural de la cultura del cuerpo, pues como lo señala Arboleda (2008) en relación con la identidad y el miedo en el caso colombiano: con

... cultura corporal se hace referencia a la manera contundente en que cada estructura social y cultural ha marcado el cuerpo; ello connota un concepto de este último, [sic] que ha desbordado a la organicidad y ha comprometido al entorno que lo acuna. Entre cuerpo y cultura se ha generado una relación en la que ambas partes se han permeado y se han co-construido; [lo que] [...] ha dejado improntas susceptibles de rastrear... (p. 63).

Dicha cultura corporal, en perspectiva histórica y desde los marcos sociales mencionados, provoca reacciones particulares que las comunidades hacen de sus propias tragedias, sus resistencias, sus maneras de enfrentar o de sus prácticas de naturalización del hecho victimizante. 
La llamada denegación de la muerte y el genocidio enunciado por Murillo (2008), para el caso argentino, permite pensar en las formas de protección que el sujeto erige para enfrentar esos traumas. Para el caso de la desaparición particularmente adolece de cierre por el hecho de tratarse de una ausencia sin retorno, pues la pérdida del cuerpo se inscribe como falta que, para el caso colombiano, puede tornarse en espera ambigua, en expectativa de aparición o, también, en fantasma de algo que puede retornar como repetición de lo acontecido.

En el proceso denegatorio, Murillo (2008) mencionó el lugar de la vinculación con un pasado traumático y el horror que este engendró; de ahí el miedo a las relaciones que se puedan realizar respecto a lo que se hizo, con quién y en qué momento:

La denegación de un hecho conlleva, como lo ha explicado hace mucho Freud, el rechazo de todo aquello que asociativamente se vincula con él. La operación denegatoria que se observa en estas entrevistas opera borrando de la memoria histórica todo un proceso, pero además [ $\mathrm{sic}]$ liga asociativamente de modo inconsciente a ese horror la actividad política. De ese modo [sic] en muchos sujetos, a la hora de efectuar entrevistas, surge la desvalorización de la política [...] y "los políticos". Las respuestas sugieren rechazo y una especie de temor a ser vinculado con cualquier actividad política. Lo político está cercano asociativamente con la muerte. Se apuntala desde allí, como veremos, la recodificación y el acallamiento de la memoria histórica en el análisis del presente (p. 97).

A diferencia del caso argentino trabajado por la autora, en el caso de Colombia, al tomar ejemplos como los de la comunidad de TrujilloValle del Cauca - a la cual se ha hecho alusión varias veces por el papel que jugó para la recolección de información de esta investigación-, la vulnerabilidad producto de esta denegación y ordenada en el sentido de la ausencia de cuerpo-muerte-ritual-duelo, no es limitada en el miedo al retorno del recuerdo y a los vínculos o evasiones con el pasado, sino en la posibilidad de la repetición concreta del acto por parte de los victimarios, debido a los niveles de impunidad que, después de veinte años, aún se presentan. 
Emerge entonces la diáspora política atravesada por el sujeto al habitar varios territorios, al mismo tiempo, entre el discurso de un Estado que, en papel, es garante de servicios y una ejecución de esta premisa por medio del Gobierno, en la cual este ha sido cómplice competente en administrar la muerte por medio de la impunidad. Por tanto, entra en cuestión un Estado que, constitucionalmente, garantiza una idea de justicia; pero que no se corresponde con un Gobierno que, legalmente, no hace nada para gestionarla.

La justicia es entonces el principio polémico entre el papel del Estado y la efectividad de sus acciones en mano del Gobierno. El caso de Trujillo es uno de tantos ejemplos, el cual inició en 1989 y se menguó significativamente a finales de los 90; sin embargo, registró, posterior a esta fecha, casos continuos de desapariciones forzadas y asesinatos donde solo se encuentra en proceso judicial, en la actualidad, un militar y el mayor del Ejército Alirio Urueña, y judicializado un conocido narcotraficante de la zona llamado Henry Loaiza alias «el Alacrán» que, vinculado con otros tres militares, fue parte activa de un proceso que tuvo sus picos más altos entre 1989 y 1995. Hasta el momento se cuentan con 342 víctimas entre asesinados y desaparecidos.

Según la propia comunidad, aún se presentan casos aparentemente «aislados» de desaparecidos igual que de asesinados como el del líder indígena Daniel Niaza, el cual fue abaleado en marzo de 2013 en zona rural de Trujillo. El Estado, en 1997, pidió disculpas públicas frente a su responsabilidad con lo sucedido, dadas las pruebas que demostraban el papel del Ejército en los hechos. Aunque tales disculpas se dieron a 34 del total de las víctimas, esta situación marcó un precedente que, sin embargo, no trajo resultados efectivos en cuanto a la responsabilidad judicial de los victimarios.

El acto político de reconocimiento de culpa implica matizar una distancia entre la razón gubernamental y la razón de Estado, ya que, al no contar con responsables concretos, la idea queda en entredicho, igual que como lo señalaba Arendt (2007) respecto a la responsabilidad política, cuando todos son culpables ninguno es responsable. El argumento del perdón que esgrimió el Estado colombiano no implicó personajes específicos que, al estar vinculados con este mismo, deban 
pagar por lo sucedido. Dicha institución se difumina en una imagen ininteligible donde el Gobierno queda en paréntesis respecto a su papel y a la responsabilidad con los miembros de la comunidad.

\subsection{Gobierno vs. Estado}

Partiendo de la idea de concebir el Estado como un ente inmaterial, al seguir a Foucault (2010):

El estado [sic] no es ni una casa, ni una iglesia, ni un imperio. El estado [sic] es una realidad específica y discontinua. Sólo [sic] existe para sí y en relación consigo, cualquiera sea el sistema de obediencia que deba a otros sistemas como la naturaleza o Dios (p. 20).

Se debe comprender que esta noción si bien es fundante en la práctica estatal, el autor realmente la aclara para destacar el riesgo del comportamiento del mismo, ya que la idea de Estado puede caer en un sincretismo inmaterial.

Sin embargo, en el caso colombiano el cuerpo constituye un registro material y un registro concreto de la razón de Estado donde el miedo expresa la efectividad de este mensaje. Según Arboleda (2009) «... el miedo, ya como pasión, como reacción, como inscripción o como resistencia, aparece como un elemento que interviene en la cultura corporal de los individuos en un entorno social determinado») ( $p$. 136). En dicho entorno el cuerpo es la materialización del miedo en un ejercicio de poder desde la aquiescencia de actores del Gobierno que representan la soberanía del Estado y se encuentran vinculados con grupos ilegales articulados al mismo.

En el ejemplo de Trujillo, todos ellos articulan la institucionalidad gubernamental a partir del ejercicio del control político mencionado por Foucault (2010) no solo sobre el cuerpo vivo, sino sobre la administración de la muerte de este con la impunidad o con la incertidumbre de la ausencia del cuerpo para, de esta manera, ejercer en lo concreto un dispositivo de dominio sobre el comportamiento 
social sin ser plenamente un proyecto político que dé cuenta de una razón estructural de Estado, sino de un ejercicio funcional de control del mismo con aquellos actores que están cubiertos de su legitimidad.

Allí, las víctimas parten de la figura legal y pública de quien la ejecuta o bajo la cortina por la cual son protegidos. De esta forma, intentan comprender tal acto sin que en el fondo se discriminen las acciones estructurales de Estado, de las razones funcionales en nombre del mismo, pues los miembros del Estado actúan en busca de beneficios particulares. En ese sentido, es necesario pensar en el momento que Foucault (2010) inicia una genealogía de las razones de Estado en términos históricos y trata de mirar entre paréntesis las posibles cercanías o distancias que ha tramitado el caso colombiano respecto a zonas afectadas por la desaparición forzada.

Una de las formas tradicionales de razón de Estado la constituye, según el autor, «una regulación, una limitación de hecho», la cual, distanciada de la idea de un Estado limitado en derecho, trata de poner en evidencia la razón de Estado cuando esta se encuentra vinculada con las decisiones menos convenientes consigo mismo; una noción de Estado «inadaptado» e inconveniente con sus propios intereses, pues se podría pensarse aquí en casos como el de las experiencias dictatoriales en el mundo a partir de figuras autoritarias y hasta delirantes.

Respecto al caso colombiano, en lugares afectados por la desaparición forzada es común que tal limitación de hecho no se presente de manera tan desestructurada, pues las constantes relaciones entre grupos ilegales como paramilitares y la fuerza pública ${ }^{21}$ establecen un conducto que la comunidad tiene plenamente identificado y que, al momento de ser visible en especial por órganos internaciones, se omite o se busca una persona que asuma la responsabilidad como si fuera una acción de Estado impulsada por la iniciativa de un solo sujeto.

21 A pesar de existir amplia información respecto a estos vínculos, uno de los casos en los últimos años lo representa el General Mauricio Santoyo, antiguo jefe de seguridad del expresidente Alvaro Uribe y quién ha reconocido, en el mes de agosto de 2012, sus relaciones directas con grupos paramilitares; relaciones que, además, sostenía en el momento de asumir como responsable de la seguridad del antiguo mandatario. Cabe destacar que Santoyo fue eximido de una investigación sobre chuzadas ilegales en el año 2003. 
Un mensaje de doble intención que por más que busque cauterizarse con una idea abstracta de culpa o con un solo personaje «autónomo», lo único que deja en evidencia es que la razón de Estado, en casos concretos como estos, está plenamente inspirada en la impunidad y no en la ingenuidad como busca mostrarse en algunos momentos. Un ejemplo de ello es la respuesta de los hombres más cercanos al expresidente Uribe y las respuestas de él mismo ante un aparente desconocimiento cuando se descubren relaciones entre él y/o sus hombres de más confianza con grupos paramilitares ${ }^{22}$.

La razón de Estado diseña un interés donde son someras las intenciones de ocultar la verdad sobre los medios para la aplicación de una política que lo lleve a cabo. Si bien se menciona el caso Uribe por lo reciente, es tan solo una muestra de la repetición histórica de estas estrategias, las cuales cambian el dispositivo, tal como lo enunció Murillo (2008) respecto a América Latina a mediados de los sesenta, de la administración de la vida a la administración de la muerte, al enviar un mensaje colectivo que posicionaba al victimario por encima de cualquier culpa moral y al buscar romper la cohesión social para ubicar la población en un estado de extrema vulnerabilidad ante la barbarie de Estados donde la población ve el rol permanente del Gobierno con los sucesos; situación aún más coercitiva para el imaginario social de la comunidad, pues como lo plantea Murillo (2008):

El poder entonces dejó de gestionar la vida de las poblaciones, para administrar la muerte. Al menos en Argentina, la muerte cesó de ser una imaginaria representación de algo "que le pasa al otro"; las instituciones ya no fueron un lugar de procesamiento de la angustia concomitante a la presencia de la muerte. La condición trágica de lo humano aflora con intensidad en tiempos en los que la muerte se presenta como ecuación insoslayable, y esa condición trágica encuentra serias dificultades para ser procesada. El terror reenvía a una situación de desamparo primordial, que ensimisma a los sujetos y rompe los lazos sociales (p. 94).

$22 \mathrm{Al}$ respecto ver el artículo titulado «Los hilos invisibles entre la oficina de Envigado y el entorno de Uribe» de la revista La Silla Vacía. 
En el caso de Trujillo también se administra la muerte, se busca romper los lazos sociales y se afirma la angustia como componente básico de la vida asociativa. Adicional a esto, con el discurrir del tiempo se muestra que, igualmente, se administra la justicia de forma arbitraria; que no hay una pausa para pensar en lo sucedido y en sus responsables; y, por el contrario, se prolonga la impunidad y la intimidación como mecanismos de control.

El poder se ejerce precisamente en el nodo de la angustia y del trauma. La desaparición es un mensaje abierto, el cual se escribe cada día de diversas formas y con distintos lenguajes, y busca su tinta en el dolor de una página que no se cierra.

Las sociedades neoliberales, al proyectar la seguridad como epígono de su accionar, crean una apertura donde esos mensajes que dan cuenta del poder y de las prácticas sedimentadas con el mismo se configuran con matices propios.

La aparición del modelo neoliberal en Colombia se da a principios de los noventa en el marco de una leve disminución de uno de los momentos más violentos de la historia política del país; se presenta una especie de pacificación económica por medio del libre mercado, lo cual permite el ingreso de nuevos capitales, así como la negociación y el exterminio de aquellos actores que podían ser problemáticos para el libre desarrollo de la nueva dinámica económica que empezaba a enfrentar el país.

De esta forma, la noción de «biopolítica» no es exenta de estos cambios de esa regulación de hechos, los cuales no fueron plenamente un proyecto de Estado, sino que atentaron contra este como acción inadaptada al contexto. Sin embargo, es importante aclarar que sí existió una apuesta económica de gremios interesados en la implementación de un nuevo modelo con la complicidad del Estado, pero no como una política del mismo.

En ese sentido, la «biopolítica» también sufrió nuevas prácticas que ubicaron el control por el cuerpo social de la población con nuevos dispositivos de recrudecimiento de la violencia; una mezcla entre una 
nueva apuesta ciudadana al mundo por medio de un modelo que abrió fronteras a grandes monopolios, mientras cerraba oportunidades para la pequeña y mediana industria nacional; y una reterritorialización del campo por medio del aumento de grupos paramilitares en grandes zonas del país, todo esto al usar como dispositivo primario la idea de seguridad y protección.

Al respecto, Foucault (2010) referenciaba la construcción de la seguridad como dispositivo desde tres puntos:

Primero, la ley universal, la protección y las garantías desde un enfoque global que, en el caso de Trujillo, se hacen contradictorias sus aplicaciones, pues son las garantías de la ley universal donde el sujeto de derechos es lo primero que se anula, dado que la ley es local y se erige en la aplicación del poder por medio de un aislamiento de las víctimas y sus derechos respecto a una distribución de los victimarios y a su lógica de control. Muestra de ello son las jerarquías que grupos, tanto militares como paramilitares, tienen a su interior donde cada decisión pasa por conductos de poder previamente establecidos.

«Hernando», un sobreviviente de Trujillo, cuenta una historia sobre el lugar donde lo torturaron; un coliseo de dos pisos donde habían espacios para distintos tipos de intensidad en la tortura y donde, en todo el sitio, se veía al «Alacrán» decidiendo que se le hacía a cada persona. Es claro que el verdugo no pretende ni universalizar la ley, ni, mucho menos, el castigo, lo que hace es crear distinciones o juicios a partir de la responsabilidad que, considera, tiene cada actor en la dinámica pública de la comunidad.

Segundo, las disciplinas, la formación de hábitos, ciertos ejercicios en la escuela, la cárcel, la fábrica, entre otros donde se crea un disciplinamiento no como la formación de un hábito que se interioriza, sino como intimidación que respeta las lógicas de comportamiento en una población o grupo social.

Para el caso analizado, el victimario en la desaparición forzada establece una interiorización de la política de violencia que ejerce y una demostración de la capacidad de violencia extrema que se puede 
aplicar, al reedificar la estructura social y los papeles que determinan el lugar ocupado por cada actor.

Un ejemplo de esta resignificación de los estatus y los roles impuestos es el caso antes mencionado del párroco de la comunidad de Trujillo, el padre Tiberio Fernández, el cual fue una de las primeras víctimas de la oleada de desapariciones en la comunidad. Como se trabajó en un capítulo anterior, es significativo que haya sido con este sujeto el inicio de un proceso de violencia extrema donde él fue torturado y desmembrado, y sus partes fueron distribuidas por distintos lugares; además, los lugareños dicen que su sobrina fue violada reiteradamente antes de ser desaparecida. Estos actos implicaron marcar, de entrada, una lógica clara a la hora de establecer los límites hasta donde se podía llegar con esta nueva estructuración de hábitos, figuras de autoridad y consecuencias de no respetar la norma de poder establecida por los victimarios.

Aunque es claro que Foucault (2010) jamás pensó en esta crueldad sobre el cuerpo cuando trabajó el concepto de «disciplina» del mismo, ya que dicha práctica habla más bien de un ejercicio de poder martirizante, es innegable que esto interviene en la noción de algunas características del ejercicio de la «biopolítica» ejecutado en la comunidad.

No es fortuito leer como el sacerdote, con la protección institucional de la iglesia y el semblante espiritual de Dios en comunidades de tanta devoción católica, fue el portavoz de un mensaje que se pensaba inscribir reiteradamente en el cuerpo de varios miembros de la comunidad. Sin embargo, esta acción simbólica con la desaparición forzada no es nueva y obedece a una intención diseñada no solo en el dolor, sino en la búsqueda por mostrar un límite que no respete códigos culturales, religiosos o humanitarios de ninguna manera.

De igual forma, como se hizo alusión antes, en relación con el primer caso oficial registrado de desaparición forzada en Colombia en 1977, Omaira Montoya junto a su compañero Mauricio Trujillo, militantes de izquierda, fueron detenidos en el marco de un paro cívico nacional. A Mauricio lo torturaron, pero fue judicializado varios días después; Omaira, por su parte, nunca más regresó, no se supo nada de ella ni de 
su hijo, pues como se desarrolló anteriormente estaba embarazada al momento de la detención.

Es indiscutible que este precedente simbólico marca los acontecimientos de la historia de la desaparición forzada en Colombia, pero también es innegable lo que se constituía como un marco de control sobre el cuerpo o una estela de elementos de la «biopolítica» más allá de, simplemente, querer disciplinar o eliminar una persona.

Un tercer elemento destacado por Foucault es la representación. En el caso abordado, la condición propia de los actos que se ejercieron en la comunidad de Trujillo relacionan rasgos de la «biopolítica» como disciplina sobre el cuerpo subjetivo y sobre la población, allí la naturaleza más explícita de estos hechos es representada por la desaparición forzada o por los asesinatos selectivos en dichos contextos debido a que el cuerpo social se domestica hasta su expresión más íntima; y el desaparecido, al igual que el asesinado, es más que su subjetividad, a saber, aquello que es representado para los testigos de lo sucedido, los cuales son, al final, el objeto central del mensaje emitido. «Martha», familiar de una víctima asesinada en «El Salado» —otra masacre ejercida por un grupo paramilitar en Colombia en febrero del 2000-, decía respecto a la muerte de su hermano: «... cuando lo mataron no lo enterraron a él solamente, sino a toda la familia» (Irene, comunicación personal, marzo de 2013).

Las prácticas desde la «biopolítica» inscriben en el cuerpo de las víctimas, de sus familiares y de sus victimarios un lenguaje social que se articula con la negación del sujeto de ley universal y la redefinición de hábitos y jerarquías; sin embargo, precisamente el hecho de no constituir complemento de la ley de manera oficial no permite pensar el concepto desde la naturaleza plena que estructuró Foucault para definirlo.

Finalmente, la seguridad se convierte en un recurso adverso a la intención de naturalizar e interiorizar la norma como lo rastrea Foucault (2010) no por el papel que esta representa, sino por la forma de usarla para poder garantizar unas lógicas de dominación por medio de la coacción. 


\subsection{Rasgos de la biopolítica de Estado, estrategias de fragmentación}

Si bien el análisis de los conceptos de Foucault presenta distancias evidentes respecto al caso concreto mencionado, el abordaje puede tener ecos bastante próximos a lo que el mismo autor llama el método de comprensión de las prácticas del Estado, o las críticas al mismo y sus aplicaciones en la sociedad actual. Foucault (2010) explica por qué desde el origen del neoliberalismo, en especial del neoliberalismo alemán, hasta las críticas en el accionar estatal, se evidencian elementos constates y recurrentes en su comportamiento en la actualidad.

Una primera noción da cuenta del carácter expansivo del Estado por medio de políticas focalizadas hacia el control de la sociedad civil, pues su mirada se obtura en esta, e interviene en sus prácticas y en sus desarrollos:

Una tendencia intrínseca a crecer, un imperialismo endógeno que lo empuja sin cesar a ganar en superficie, en extensión, en profundidad, en detalle, a tal punto, y también que llegaría hacerse cargo por completo de lo que para él constituye a la vez su otro, su exterior, su blanco, y su objeto, a saber la sociedad civil (p. 219).

La «sociedad civil» como objeto principal, al cual se dirige la intervención de Estado, permite, en el caso mencionado, ubicar los diferentes lugares que desde Weber (1984) caracterizan la distinción entre lo legal y lo legitimo. El Estado es legalizado por la constitución política, pero es legitimado por sus prácticas; la relación entre Estado y paraestado con acuerdos comunes en el marco de reciprocas utilidades ${ }^{23}$

23 La creación de los grupos paramilitares en Colombia funge desde dos aspectos: inicialmente fue la posibilidad de implementar una campaña de guerra sucia aparentemente en un fuero distinto a la seguridad implementada por el Gobierno, de allí la intervención del paramilitarismo era concentrada en la persecución de líderes de derechos humanos y disidentes organizados o no de las políticas de Estado. Como segundad medida y con mayor frecuencia se establecieron acuerdos entre grupos paramilitares y el Gobierno donde los líderes de los primeros encabezados por terratenientes y mercenarios (muchos exintegrantes de la fuerza pública) implementaron políticas de asedio que, por un lado, regularon, por medio de la intimidación y el exterminio, las políticas de Estado, pero, por el otro, garantizaron el control y el poder de grandes extensiones de tierra a estos cabecillas. 
legitima, con escenas como la desaparición forzada, prácticas de una búsqueda de control político sobre el cuerpo a partir de la angustia y con más fuerza que la del terror, ya que según Freud (2006) el terror se puede manifestar sobre un objeto puntual, el cual puede retornar de múltiples formas en la vida del sujeto, a partir de traumas más o menos concretos, es decir, su reconocimiento se puede obturar, mientras que la angustia no tiene una forma clara de asirse; esta es un estado continuo de vigilia con el miedo, con el malestar y con la incertidumbre hacia el futuro.

La sociedad civil presencia una intimidación directa sobre miembros de la comunidad, pero también activa una política de proyección sobre la posibilidad de ser todos culpables de un hecho que no han cometido y el cual pueden pagar con el cuerpo, pues el terror del trauma es el mensaje a las familias por medio de la espera de su ser querido, pero la angustia es el mensaje a todos los miembros de la comunidad con una intranquilidad continua.

El carácter expansivo del Estado sería más bien una concentración del control territorial-regional sobre los cuerpos sociales. La intención de esta institución sería entonces negociar fracciones de su territorio para garantizar la implementación de políticas no de Estado, sino de intereses particulares sin mayor resistencia; un ejemplo de ello es el proceso jurídico de «Agro Ingreso Seguro», en el cual el exministro de agricultura del gobierno de Álvaro Uribe Vélez, el señor Andrés Felipe Arias, adjudicó subsidios millonarios del Estado para el apoyo al campesino y a la estimulación de la crisis del campo a reconocidos latifundistas, políticos y ganaderos, muchos de ellos vinculados con paramilitarismo y grandes proyectos empresariales.

Otro caso destacable es la concesión y otorgamiento de megaproyectos para hidroeléctricas, minería a cielo abierto, aeropuertos, entre otros, los cuales son de carácter privado en zonas de alto impacto social y ambiental.

Pensar las relaciones entre el lugar de la sociedad civil, las políticas de Estado y el papel de prácticas en pro de un proyecto biopolítico implica recordar que la naturaleza del neoliberalismo, en el caso 
colombiano, busca el desarrollo y la protección del capital privado con una intervención inicua del Estado donde se procura el cuidado parcial de una clase media, pero se desatiende, con frecuencia, las brechas económicas entre clases altas y bajas, en las cuales las primeras deben asociarse a grandes monopolios internacionales para poder sobrevivir en la competitividad mundial.

Nada de esto es nuevo en el marco de las políticas formuladas para América Latina desde el Fondo Monetario Internacional (FMI) y apoyadas por el Banco Mundial, pero lo que se dilucida en la sedimentación del caso nacional tiene que ver con la inconsistencia entre la razón de Estado, sus políticas y sus proyectos como una pretensión de control económico, político y social a nivel nacional, pues más bien se hablaría de prácticas bajo su tutela desde intereses regionales.

Las múltiples máscaras de un Estado legal es su papel, el cual se legitima con otros actores fuera del establecimiento público o amparado por el mismo, situación que lo condiciona a ser una institución que apela a distintos órdenes de poder y de verdad para respaldar sus políticas, es decir, su régimen de veridicción es incierto, pues sus medios están invadidos de varios relatos y la razón de Estado es tan solo un mecanismo no un fin último, ya que este depende de las verdades construidas en los territorios por la política que se busca desarrollar en cada zona.

Al pensar la estructura de estos regímenes de verdad, Foucault (2010) describe una arqueología de ellos y establece los elementos que hacen posible su funcionamiento. En la anatomía de la verdad en contextos locales como el mencionado, inicialmente se deben tener en cuenta las particularidades tejidas desde ámbitos más generales; es el caso de la violencia como mecanismo de coacción en ciertas poblaciones, pues esta obedece a un relato institucionalizado en todo el país, en el cual mercados como el del narcotráfico ${ }^{24}$, controlados por una gran cadena de actores legales e ilegales, determinan una política que se extiende

24 El caso de Trujillo es significativo, pues padeció y aún enfrenta un fenómeno de violencia vinculado con la represión política de la persecución del Estado con actores sociales, en especial de izquierda; empero, las relaciones económicas de la zona están supeditadas al negocio de la droga y a la asociación de narcotraficantes con militares, exmilitares y políticos 
por distintas zonas del territorio; una verdad que refleja el continuo comportamiento de la política de Estado y su particular fracaso en el enfrentamiento del narcotráfico donde es común ver los continuos representantes de la política nacional en procesos jurídicos por vínculos regionales con estos actores ${ }^{25}$. La verdad es entonces un proyecto de indagación inacabado, pues la lógica regional coincide bastante con la relación entre Estado e ilegalidad, pero sin mayor claridad en los acuerdos estructurales de miembros de la política nacional con los planes de desarrollo en las regiones.

En las dictaduras del hemisferio sur fue común ver el régimen de veridicción promovido por el discurso neoliberal de la seguridad y el papel del régimen fue notorio al querer explotar esto y volverlo funcional en las políticas de Estado demarcadas por el Fondo Monetario Internacional y el Banco Mundial. Sin embargo, este proyecto no solo militar, sino ideológico, permitía ver con algo de claridad esa idea de verdad de Estado y sus ejecuciones en la política de cada país.

El caso colombiano es más confuso en cuanto a un régimen de veridicción bastante espeso en su grosor; la violencia política es la expresión más clara de sistemas de control y dominación de poblaciones enteras, pero el discurso de Estado escondido en ella es bastante maleable con los intereses de particulares dentro de sus objetivos.

No solo circula la droga, sino también nuevos mercados de lo legal y lo ilegal y, junto con ellos, la verdad de los rostros de tales proyectos, la cual aún está por develar, pues los rostros de los capos de los cárteles son visibles y claros en sus intereses, pero aquellos que están tras las sombras son los de mayor grado de complejidad, dado su papel activo en la política nacional.

de la región. Se destaca el mercado de la droga como el eje que moviliza la represión, pues bajo estigmatizaciones características de la violencia política se redefine un orden social, el cual permite garantizar toda la infraestructura que mueve dicho mercado.

25 Hasta hace menos de cuatro años el 20.2 \% del Senado de la República de Colombia estaba vinculado en procesos de investigación por paramilitarismo. De ese porcentaje, el $100 \%$ eran representantes que hacían parte del partido del presidente Uribe o miembros de partidos que eran de la coalición de Gobierno. Al respecto ver el escrito llamado Balance político de la parapolitica escrito por Claudia López y Oscar Sevillano. 
La circulación del mercado de la droga obedece a las mismas dinámicas que Foucault (2010) mencionaba en 1979 respecto al resultado logrado en el intento por desmantelar redes de refinación y distribución, en 1960, en algunos países de Europa:

En primer término, aumento [sic] el precio unitario de la droga. Segundo [sic] se favoreció y fortaleció la situación de monopolio y oligopolio de unos cuantos grandes vendedores, grandes traficantes y grandes redes de refinación y distribución de drogas, y como efecto monopólico y oligopólico, hubo un alza de los precios en la medida en que no se respetaban las leyes del mercado y la competencia. Y tercero y último, otro fenómeno entonces más importante en el nivel de criminalidad [...] esa inelasticidad de toda una clase de demanda de drogas hará que la criminalidad aumente (p. 299).

Aunque la lógica del mercado y su intento por combatirlo coincide con el caso trabajado por el autor, las imbricaciones cambian en los segmentos de poder, gracias a que se establecen distintos niveles de elaboración, circulación y distribución. Así mismo, el resultado de las leyes de persecución al tema es estratificado con el tipo de población a neutralizar y evidencian mayor énfasis en mandos medios y bajos a la hora de perseguir y judicializar.

Es por eso que la verdad es un mensaje, el cual no busca ser interiorizado. Aquello que se interioriza es la política implementada sobre un cuerpo particular o sobre un cuerpo social; pues se toma distancia de la búsqueda de los regímenes de veridicción, los cuales se usan en el paso del liberalismo al neoliberalismo y en la medida que adolece de una intención epistemológica, la cual busca una ideologización. Se trata de una aplicación de la ley y de las prácticas de poder sin relatos mediadores que configuran percepciones sobre la realidad en hábitos concretos. No hay evidencia que permita trabajar las prácticas aplicadas, ya que la filosofía es la instauración del miedo por medio de la angustia y la intimidación, pero sin una arqueología que articule claramente lo sucedido. 


\subsection{Trujillo y los retazos del caso en un rompecabezas nacional}

Es frecuente escuchar en las historias de los pobladores de Trujillo, «... todos sabíamos quiénes eran» (Virginia, comunicación personal, julio de 2014), «... uno los veía llevándose gente en carros militares, pero nadie podía decir nada» (Irene, comunicación personal, marzo de 2013). La idea de repudiar en silencio lo acontecido da cuenta de un aval por supervivencia y no por convencimiento de tales prácticas, la difuminación del poder en capas revirtió el paso de la coacción física a la coacción ideológica propia del siglo xx, lo cual dio de nuevo el lugar fundamental a la primera por encima de la segunda.

En el trabajo realizado por Murillo (2008) se hace alusión al neodecisionismo como práctica que se estableció en el caso argentino posdictadura y dio cuenta de esa apatía que, amparada en la necesidad inmediata, obviaba la deliberación y el consenso, y se inscribía en lo que la autora llama «fascismo societal», concepto que aclara lo ha desarrollado previamente Boaventura de Souza (2004), pero define, de manera muy cercana, esas prácticas, las cuales se han referenciado en este trabajo y donde la legitimación del acto es paradójicamente instruida desde actores legales e ilegales por medio de la represión que ahoga toda posibilidad de reflexionar lo crítico de la situación que se vive; una cadena sistemática de acontecimientos que, en el caso de Trujillo, se da desde 1989 hasta la actualidad con hechos que no dejan aliento y que, en la violencia de los actos y la recurrencia de los mismos, inspiran la lógica del poder y su control sobre la comunidad:

El neodecisionismo descalifica los valores contractualistas, el Parlamento y la diferenciación entre esferas pública y privada. En lo jurídico, opone la excepción a la norma, y como consecuencia, la fuerza de lo fáctico al orden legal impersonal. La validez de lo fáctico radica en su capacidad de decidir de modo eficiente. Esto implica un balance entre dos lógicas contradictorias: "legitimación" y "represión" (Bosoer y Leiras, como se citaron en Murillo, 2008, pp. 101-102). 
Es por esta situación que, por último, se debe entender que la desaparición forzada y las masacres realizadas en Trujillo se yuxtaponen de manera directa con la circulación del mercado de la droga y la violencia política en el país; fenómenos estructurales que, en Colombia, tienen variantes en cada zona donde las lógicas de poder representan una cadena de jerarquías de distintas índoles y donde los rasgos parciales de la política se presentan sobre el cuerpo, con este y desde este; así como la maquinaria que protege a los victimarios, los cuales ejecutan los actos, pero, al tiempo, ocultan los responsables en altos cargos políticos que hacen parte de todo el engranaje.

De igual manera, como hay grados de responsabilidad, también existen grados en la búsqueda de una conducta y un hábito social para la población, el control sobre el cuerpo y el símbolo político que esto implica, pues funciona como un elemento que establece en estas comunidades un funcionamiento desde la violencia extrema dinamizada por el silencio, la omisión, la estigmatización, el desplazamiento y la angustia, lo que constituye el cúmulo de factores para marcar una dinámica social donde se condicionan las prácticas y los roles cotidianos permitidos en estas poblaciones.

Aunque se debe aclarar que si bien la eficacia del control sobre el cuerpo de la víctima se activa con el ejercicio de sometimiento por medio de la violencia extrema, esta adquiere su transferencia con el cuerpo del actor social, gracias a las formas tradicionales en las que este, desde las sociedades del siglo Xvi como lo señala Foucault - a propósito de la cita que encabeza este capítulo-, cualifica la anatomía del cuerpo por medio de distintas instituciones, tales como el ejército, la escuela, el colegio, los talleres, entre otros, las cuales domestican un cuerpo que puede redimirse a la voluntad de un poder.

Así, quien padece en su condición de víctima ha tenido una experiencia de sometimiento con el cuerpo previamente, lo que permite que esta nueva incursión violenta, al retomar a Nahoum-Grappe, de violence extrême tenga mayores garantías y menores resistencias para ser implementada. 
En un país tan diverso, estas instituciones varían en cada contexto. Para poblaciones de tradición agraria como la de Trujillo, tres pueden ser las más visibles en este marco: primero, los intermediarios, en especial gente de la cabecera municipal que compra productos por precios risibles en relación con la venta final. El cuerpo del campesino y su familia depende del sustento de un negocio, el cual debe insertarse a las lógicas de un mercado que lo lleva a su mínima expresión frente al reconocimiento por el esfuerzo realizado y por el trabajo hecho, situación que implica la adaptación y el sometimiento a un pago que les da garantías precarias para su subsistencia, a saber, para su sustento básico.

Segundo, el Gobierno brinda condiciones de vida, de atención y de acompañamiento que, en la mayoría de los relatos, da cuenta de abandono, pues los actores sociales «instruyen su cuerpo» para afrontar, ellos solos, sus necesidades básicas como la alimentación o la enfermedad desde las limitaciones y las restricciones. En muchas casos como en las veredas donde se trabajó nunca se ha tenido un puesto de salud, les toca caminar horas para llegar al pueblo y, después de estar ahí, deben tener la paciencia para ser atendidos de forma muy básica, independiente de la gravedad del asunto. El abandono estatal es el caldo primario del conflicto, este nutre militantes para grupos alzados en armas, deja a la población en estado de permanente olvido y expone a la comunidad a cualquier incursión armada externa. El campesino asume como parte de su domesticación con el cuerpo aprender a vivir en tales condiciones, resolver él mismo sus requerimientos o aceptar que no se puede hacer más.

Tercero, los grupos armados instauran una lógica propia, un territorio definido por sus reglas, y una conducta moldeada y moldeable a las necesidades y caprichos de la autoridad que detenta el poder. Terratenientes, narcotraficantes, insurgencia, paramilitares y militares establecen control sobre el cuerpo social e individual, inicialmente desde la obediencia de la normatividad establecida y, posteriormente, desde la aceptación con sangre y fuego de la conducta; todo ello al particularizar la mirada en todo aquel que pueda contrastar sus intereses. 
Finalmente, se podría decir que los actos de barbarie señalados, en especial por el control que suscribe la última figura que se menciona, la cual «institucionaliza» una relación del poder con el cuerpo y sobre el cuerpo, están inscritos en un marco de la economía de lo ilegal y buscan, con grados profundos de sevicia, el comportamiento condicionado con la intención de garantizar lógicas de control eficientes en todo el rompecabezas de un sistema tan complejo en su estructura que requiere diversas comprensiones a partir de la multiplicidad de factores que intervienen. 


\section{Epílogo}

Los sufrimientos que más a menudo se consideran dignos de representación son los que se entienden como resultado de la ira, ya sea humana o divina (Sontag, 2004, p. 42).

El epílogo, como parte final de un texto, se desprende de lo trabajado e indica una visión sintética de lo que se desarrolló. En este documento, la pretensión del mismo se halla realmente insertada en las conclusiones, allí se enlazan las estructuras discursivas, las variables conceptuales y las evidencias empíricas producto de la investigación realizada y se da como resultado tesis finales, las cuales si bien no se pueden tomar como concluyentes, sí exponen el alcance de investigativo a partir de una pregunta y unos objetivos que sufrieron múltiples avatares durante todos estos años.

Anticipar planteamientos previos a las conclusiones con el nombre de epílogo, sin que literalmente sea esto, es más bien una apuesta por darle un lugar privilegiado al fracaso de una intención que, al encontrar desafíos en el trabajo de campo, no se pudo concluir, debido a la magnitud de un tema con tantos laberintos como lo es la desaparición forzada de personas en Colombia.

Esta situación tiene que ver con el enunciado de la introducción, el cual se trazó como meta trabajar la noción de víctima más allá de los familiares, ya que sobre estas distinciones, familiar-victima directa-habitante-poblador-testigo se construyen, muchas veces, las representaciones sociales de la génesis de un conflicto que, como se ha mencionado, interviene a los pobladores por medio de un ejercicio de control, sometimiento y desaparición del cuerpo del otro, lo cual va dirigido a toda una comunidad y no solo a sus consanguíneos.

En la metodología se aclara, en parte, la idea de las víctimas y sus relatos, al igual que en varios de los capítulos desarrollados. En dichos apartados fue importante insistir en el mensaje colectivo que se 
esconde tras un hecho focalizado, el cual supera la noción de enemigo o contendiente e, inclusive, lleva la misma noción de víctima a lugares inusitados, tal como lo señala Estrada (2016) en un texto reciente sobre la escritura del horror en los cuerpos donde dice:

La violencia criminal u homicida contemporánea llevada a sus extremos se manifiesta como un tipo violencia, cuya finalidad no es ya el acto de quitar la vida, sino la destrucción del cuerpo marcado por el simbolismo de crueldad como forma de atentar contra la dignidad y la condición humana, la cual es conceptualizada en este artículo como violencia ontológica. El cuerpo es un discurso social y, junto con la mente y espíritu, un elemento constitutivo de lo humano, por lo que su desaparición, tortura, mutilación y desmembramiento, verifica la desarticulación psicológica y social de la condición humana, convirtiendo el cuerpo del cadáver en un mensaje deshumanizante del horror social (pp. 57-58).

La ruta hacia la «biopolítica», también mencionada en un apartado del texto, es bastante consecuente con este enunciado de Estrada, pues el cuerpo, más allá del cuerpo, es un enclave por momentos indescifrable e incomprensible de la formulación de control del victimario.

La ritualidad no solo se ejerce como dispositivo de representación social de los pobladores afectados, también es una práctica estructurada por los victimarios para la efectividad física y simbólica del sometimiento y no un mensaje que, al tener un costo económico y social tan alto - ya que es más sencillo asesinar que desaparecer- es deliberado o intencionado a un actor puntual y va dirigido a todos los habitantes del territorio donde se perpetra la desaparición.

La subjetividad se activa como medio para asumir una responsabilidad diferente entre los familiares y los otros que no tienen un desaparecido, pues estos últimos son susceptibles al hecho. La bibliografía, la documentación y, en ocasiones, las intervenciones de oenegés y del Estado mismo se concentran precisamente en los primeros, sin con ello negar que existe atención ocasional sobre los otros pobladores. 
No obstante, es en la idea de víctimas «inmediatas» donde se retrata el trauma latente del padecimiento, inclusive los mismos pobladores terminan asumiendo distancia, solidaridad y precaución, a saber, marcan una distancia simbólica y territorial identificable para todos.

El trabajo de campo dirigió la mirada hacia la voz de estas víctimas en el tratamiento de los resultados, ya que, aunque se trabajó con pobladores en general, al tratar de no caer en un sincretismo que martirice aún más el dolor de unos sobre otros, la naturaleza del discurso de aquellos que no son familiares de desaparecidos denotaba con frecuencia la entrada y la salida de su posición ante lo sucedido, reconocía el dolor del otro, identificaba su angustia, prestaba su apoyo y tomaba distancia o no quería hablar del tema. Estos fueron fragmentos enunciados por ellos en distintos momentos.

El espeso nudo del dolor y del discurso arrastró hacia la homogeneidad del sufrimiento, la generalización del sujeto que padece, la lógica tendencial de una víctima, una condición victimizante y un cerco social de atención; la deriva de la palabra de los pobladores hizo de esa narración una construcción ambivalente del discurso no por sentirse ajeno o indiferente, sino por protegerse del efecto que puede suscitar el mismo.

Estas variables del enunciado convierten la historia de la tragedia en un fractal social; miles de voces en una vozy cambios repentinos de lugar ante el otro, de la desprotección a la inculpación, del recuerdo al olvido, del perpetrador a la cultura, el padecer atemporal, la condensación del sufrimiento en pliegues aún inciertos para los que se intenta entender lo sucedido, pues el reduccionismo del otro alimenta la distancia para saber cómo investigar e intervenir.

A pesar de ello, la pregunta no recae solo en el inmenso diámetro del conflicto y su comprensión, también pasa por abordar ¿cuál es la razón real del verdugo por encima del control territorial en términos materiales y sociales? Siguiendo a Agamben (2003), es el ejercicio de un poder soberano sobre lo que él denomina «estado zoé de la nuda vida», el cual reduce el cuerpo a una condición estrictamente biológica y, de ser así, el 
hecho de desaparecer como mensaje inscrito en la violencia del cuerpo no del desaparecido, sino de los otros que lo presencian, no se convertiría en una condición social más que biológica, ya que es, precisamente, la base del acto. Un efecto más colectivo que individual no sería reducir a lo biológico, sería resignificar el lugar social al desaparecido, y reubicar el orden, los roles y las posiciones en el territorio a partir de la norma que se pretenda implementar.

La acción bárbara no sería anárquica ni azarosa, esta constituye un ejercicio de control ejecutado con un desdén por las condiciones primarias de respeto por los demás, el cual supera la misma razón de ser que lo motivo, pues no hubiese sido necesario llegar hasta ese extremo para generar tal control.

Leer al tirano como un perpetrador atrapado por su propio goce no es suficiente para entender la lógica de lo sucedido; aquí, el delirio es obsesivo en cada paso; y la ritualización del desaparecer, desmembrar, asesinar y elegir quién aparece, de qué manera o que parte de su cuerpo - si aparece finalmente o no- es un crimen sistemático, planificado y ejecutado con tal capacidad de acción que requiere dispositivos de control en un amplio territorio.

Después de tantos años las personas parecen todavía neófitas en el tema, ya que como lo indica la tesis de Estrada (2016), la violencia tiene una ontología propia que, para el contexto colombiano, sigue siendo incierta:

En ese sentido, la violencia ontológica es más que la búsqueda del placer sádico de la violencia por la violencia, es un mensaje que exige ser interpretado y cuyos significados son socialmente compartidos, aunque - como se verá-, el principio de horror sea la inmovilidad, la estupefacción, el congelamiento del cuerpo testigo, incluso en su dimensión social. Por ello, se trata de una violencia llevada a sus límites, es la expresión de la desmesura y la locura social (p. 74). 
Desenmarañar la base que moviliza el perpetrador requiere un trabajo independiente y concentrado en las consistencias, identidades y decisiones autónomas o heterónomas que, en cada momento, han decidido asumir.

Acercamiento que sí se puede plantear a partir de lo realizado, a manera de epílogo, ya que no logró tener el material suficiente para ser desarrollado en un capítulo de forma independiente por la densidad la información, pero tiene la pertinencia para ser incluida así sea de forma muy general en este cierre, pues tiene que ver con los efectos colectivos que el acto criminal dispone desde el ritual de la violencia política en el caso de la desaparición forzada.

La melancolía y el dolor atraviesan el estado psíquico del familiar del desaparecido al ocurrir el acontecimiento traumático. La angustia anclada en un profundo miedo es frecuente en todos los testigos de lo sucedido, pues la escena ritual realizada por los perpetradores está dirigida, en su mayoría, a instaurar y conservar el segundo par de condiciones subjetivas, más que el primero, dado que el diseño de la acción apela a un orden, a unos actores y a unos momentos que garanticen la incursión exitosa de estos grupos en una población. Por ello, el ritual es entonces su recurso simbólico más eficiente.

Cuando se hace referencia al ritual en esta investigación, se analizó el papel de este en dos situaciones específicas, ambas referidas al trámite subjetivo o colectivo que las víctimas hacen sobre el mismo. Por un lado, el ritual como manera de conservar un estado de incertidumbre y melancolía a través de actos repetitivos, en un orden concreto y con símbolos particulares para buscar preservar en el mismo el deseo de espera o la esperanza de retorno de su ser querido. Por otro lado, el ritual es visto como recurso de elaboración para el duelo, el cual es acompañado de actividades colectivas de reempoderamiento de la subjetividad del actor vulnerado, de la mano de procesos de resignificación subjetiva y a partir del anhelo de movilidad del dolor al duelo de la persona afectada.

La acción que rodea el acto del desaparecimiento forzado de personas brinda un tercer postulado del ritual al contrastar el hecho social con el sentido codificado de este, el cual es planteado por Segalen (2005). 
Primero, «se basa en criterios morfológicos», pues la violencia política en Colombia tiene prácticas tan marcadas que los actores armados poseen sellos propios en sus acciones, los cuales, si bien pueden variar, han sido tendencia en el campo morfológico de su comportamiento; por ejemplo, en los atentados a la infraestructura por parte del ELN, en el secuestro por parte de estos mismos y por las FARC-EP, en el asesinato colectivo y la vendetta por parte de grupos narcotraficantes, y en la desaparición forzada por parte de los paramilitares y el Estado; aclarando de nuevo que no se puede desconocer que estos comportamientos son propios de uno u otro grupo, pero que, en muchos momentos de la historia del país, han sido propios del proceder de unos más que de otros.

La desaparición forzada es, como se mencionó en el capítulo uno, inaugurada por las fuerzas militares de forma oficial a finales de los setenta. El desarrollo de esta práctica habla de su morfología histórica fundamentada en este mismo actor, ya que su proceder ilegal le permitía al Estado hacer uso de ella por medio de miembros de la fuerza pública, los cuales eran camuflados en grupos paramilitares. Pasados los años, tal morfología se fue reeditando y empezó a nutrirse de grupos de terratenientes, narcotraficantes y militares activos e inactivos que se unieron en un mismo equipo paramilitar o trabajaron de manera conjunta.

El episodio relatado por los testigos y los ejecutores en los actos de desaparición forzada, tanto en Trujillo como en algunos de los lugares donde también sucedió lo mismo, demarca una morfología parecida, en la cual el territorio era inicialmente despejado y, de repente, la fuerza pública que hacía presencia permanente salía de las cabeceras y se acuartelaba o se desplazaba para los márgenes de estos corregimientos; momento preliminar, en el cual se generaba una profunda zozobra de algo que sabían iba a suceder, pues este era el paso inicial para condicionar la escena. Las personas entrevistadas decían: «... nos encerramos a esperar a ver» (Germán, comunicación personal, enero de 2015), «... mi señora no dejaba de llorar» (Germán, comunicación personal, enero de 2015), «... yo le dije a él que fuera por los muchachos que estaban allá cogiendo un café» (Germán, comunicación personal, enero de 2015), pues la efectividad de este primer momento es producida, por un lado, 
por hacer pública la acción, ya que nadie puede escapar y todos harán parte de ello de una u otra forma y, por otro, por no ser una incursión repentina, sino con tiempos de ambientación.

Segalen (2005) señala como segundo criterio «la dimensión colectiva $[\ldots]$ [donde] el ritual es fuente colectiva de sentido para los que lo comparten» (p. 30). En este sentido, se exponía públicamente aquel que se iba asesinar o aquel que iban a llevarse; se compartía, se incluía y se advertía a todos los pobladores quien era la nueva autoridad y que pasaba con aquellos que podían ser objetores de esta o tan solo sospechosos. Asesinar o desaparecer niños era una forma simbólica de demostrar que no existía pudor en el acto y que no iban a tener ningún reparo en hacerlo con cualquiera.

El sentido del mensaje era masivo, hegemónico y colectivo, pues para ello se obtenía control total de la movilidad; situación que lograba una inmovilidad plena de cualquier poblador y, además, dejaba claro que existía una complicidad contundente de la «autoridad», la cual aparentemente era la responsable de la seguridad de la población. En este acto liminal se articularon símbolos físicos como el control del espacio y la movilidad dentro del mismo, y símbolos sociales dentro de los cuales jugaron un rol primario actores como la fuerza pública que se ubicó en un rol distante para lograr el efecto deseado.

El tercer elemento, en la lógica del ritual enunciado por la autora, consiste en «... marcar rupturas y discontinuidades, momentos críticos (tránsito) en los momentos individuales y en los momentos sociales» (p. 31). El cambio más visible en esta fase liminal es la inversión del orden, pues las sombras del peligro adquieren forma con la presencia de agentes extraños, los cuales encarnan la nueva representación de la ley, el control y la justicia.

Simbólicamente se armaban y se uniformaban de negro para dejar clara la noción moral ante el símbolo blanco de la paz — dicha relación con el color negro no es nueva en términos históricos-, luego reunían a los pobladores e iniciaban con la irrupción de lo cotidiano en las plazas; todo ello por medio de lecturas o discursos sobre las nuevas lógicas de comportamiento que debían tener todos los habitantes. 
Para convocar a la población se le informaba a la presidenta de la Junta de Acción Comunal que se requería de toda la gente en el lugar más cercano. Se les daba un curso amenazante, se les informaba que al Frente Sur no gustaba de los milicianos y se les realizaban advertencias (Revista Digital Verdad Abierta, 2011, s. p.).

Este fragmento lo leyó la Fiscalía General de la Nación ante los magistrados de Justicia y Paz en 2010 en una de las versiones libres de paramilitares, la cual fue recogida por esta institución. En otros casos se hacían en mesas y llamaban pobladores de manera selectiva para dejar clara la reinstauración del sitio.

La performancia de este drama no es limitada a la neutralización de los oponentes, ni a la estigmatización de disidentes políticos como en las dictaduras; es una apuesta direccionada a los pobladores de manera general, pues la eficacia simbólica del acto no se particulariza, sino que se impone de manera absoluta e intimidante, y no discrimina una condición de otra en el momento, ya que su finalidad es el ejercicio de doblegamiento del cuerpo social al martirizar el cuerpo físico.

El cuarto y último criterio trabajado por Segalen (2005) da cuenta de la eficacia y la red de sentido totalizante que se produce en la intención del discurso ritual, pues

El ritual es creador de sentido: ordena el desorden, da sentido a lo accidental y a lo incomprensible; da a los actores sociales medios para dominar el mal, el tiempo y las relaciones sociales. La esencia del ritual está en mezclar el tiempo individual y el tiempo colectivo (Turner como se citó en Ríos, 2020, p. 46).

Definidos en sus propiedades morfológicas y a través de su eficacia social, los ritos se caracterizan también por acciones simbólicas manifestadas en emblemas tangibles, materiales y corporales.

El ritual de la muerte y la desaparición forzada tiene su limen con los asesinatos públicos y con las capturas que derivarán en el no retorno de varios miembros de la población. El miedo se anuda al dolor, pero el 
efecto es profundamente angustiante para todos, ya que, al dejar claro que no hay un "proceso» muy elaborado de selección de la víctima, la posibilidad de que el próximo sea un ser querido o el mismo habitante es latente, pues es parte de lo que busca el ritual, crear una ansiedad social permanente.

En esta escena ritual no se ordena el desorden, se desordena el orden para constituir un nuevo y distinto ordenamiento. En ese paso del desorden ocasionado por el ritual, el orden emergente adquiere sentido en términos de lo permitido y lo prohibido, pero no en términos de los extremos de la sevicia para lograrlo, al contrario de lo planteado por Segalen (2005) busca arrebatar los medios para dominar el mal, ya que no depende de ellos y de las instituciones encargadas para esto. Así mismo, las relaciones sociales están a la merced del victimario y de sus propias clasificaciones, pues el ritual le garantiza ese control absoluto.

El tiempo individual y el tiempo colectivo sí se conjugan a partir de las normas cotidianas que buscan ser ejemplarizadas en el acto, Mientras dure el hecho, la intimidad de la casa y de la familia queda suspendida en el nombre del proceso colectivo de intimidación y de exterminio; por esta razón, estas actividades duraban semanas y hasta meses; y, en casos como el de Trujillo, se repetían durante intervalos de tiempo en varios años.

Todos estos criterios posicionaron la efectividad pública del evento de forma material, tangible y corporal; y concluyeron como acto ritual en la posliminalidad que se dio en la advertencia del regreso del perpetrador. El retorno del ritual, con todo lo que implica, en muchos casos dejó que miembros del grupo vivieran en la comunidad, lo cual era para insinuar que existían infiltrados de ellos por si alguien se atrevía a salirse de aquel orden, el cual dejaron instaurado y obedece a la disposición de lo que Estrada (2016) llamo «el simbolismo de la crueldad».

El desasosiego que envolvía estas operaciones de sometimiento adquirió su punto más agudo con los conflictos entre los pobladores, pues el impacto de la incursión dejó, desde lo simbólico que se recreó, 
un sitio privilegiado a la sospecha donde la tensión entre unos y otros era cultivo para la eficacia social de lo acaecido, pues se alimentaba en la cotidianidad. La necesidad de proteger el núcleo familiar implicaba distintas opciones como huir, no meterse ni involucrarse con nadie, no hablar del tema, evitar salir, establecer vínculos sociales y, ante todo, sospechar de cualquier actitud, pues potencialmente todos pueden ser víctimas o verdugos, tal como lo enunció un habitante entrevistado para este trabajo al decir: «... en ese momento, nadie sabe nada de nadie» (Claudio, comunicación personal, noviembre de 2015); inclusive algunas víctimas, después de años y a kilómetros del territorio donde se presentó la experiencia, aún les cuesta la idea de confiar en el otro.

Para cerrar este epílogo, es importante subrayar que el reconocimiento sobre aquel que padece una situación de profunda vulnerabilidad, como en el caso de las personas afectas por la desaparición forzada, no se debe entender como un estatuto que se otorga o que se suprime a partir de valoraciones inmediatistas, las cuales pretenden homogeneizar la idea del sufrimiento en primera, segunda o tercera persona.

El mensaje, el dolor y el trauma del momento fueron colectivos; no obstante, las formas de padecerlos indiscutiblemente no lo fueron, pero la mirada sobre aquello que han sufrido en el contexto de la guerra en Colombia todas las víctimas amerita mejores precisiones, abordajes y comprensiones para empezar a dar lugar a la verdad desde un hermenéutica del conflicto, la cual ayude a intervenir, auxiliar y acompañar las necesidades de todos aquellos que han sido y aún son víctimas en distintos órdenes no solo de un perpetrador, sino de una cultura, de una incompetencia estatal y, peor aún, del sincretismo social que el resto de la población les da cuando los etiqueta o estigmatiza por su experiencia de vida.

La idea de cierre quiere hacer énfasis en la «pluralidad» de los factores sociales, económicos, culturales y, de manera significativa, políticos que intervienen en el tema. Víctimas en plural, una convención más abarcante, menos excluyente y diferenciadora; marcos de victimización en diferentes órdenes antes, durante y después al asumir que cada momento habla de formas de padecimiento propias y distintas. 
Responsabilidades en niveles amplios desde perpetradores, auxiliares del delito, cómplices directos e indirectos, testigos; hasta el abandono estatal, la instrumentalización del Gobierno y la espera de que este último asuma su lugar ante lo sucedido no solo en el marco de la guerra, sino antes de que estas incursiones aparecieran. 



\section{Conclusiones}

La desaparición forzada constituye un territorio del cual difícilmente se puede escapar cuando se ha habitado la magnitud de este dolor. Las víctimas son una diáspora que se moviliza continuamente en el país para rehacer un proyecto de vida afectado para siempre. Por ejemplo, reasentarse es significar de nuevo un espacio extraño y, en ocasiones, hostil donde no desaparece el sujeto de tierras distantes, ni tampoco el sujeto marcado por la experiencia traumática de la desaparición; al contrario, esa doble condición emerge como recurso simbólico para sobrevivir.

De tal forma, investigar este fenómeno tiene mil aristas, pero lo que no posee es un carácter concluyente. Quizás lo que se podría empezar a cerrar son las lecturas parciales que buscan ser sustrato para entender las dimensiones y los impactos de la subjetividad, y la colectividad en marcos y con recursos específicos como el ritual y su eficacia simbólica en procesos de elaboración, reparación o comprensión de la naturaleza de estas prácticas.

Las ciencias sociales, al iniciar su camino en la consolidación científica, se dieron a la tarea de ejercer cruzadas para demostrar el rigor y la pertinencia de su trabajo, en especial ante las viejas querellas con las personas formadas en ciencias exactas y naturales, lo cual da como resultado un cuidado teórico particular, especialmente cuando se refirieren a la metodología y evitan caer en lecturas empíricas o poco rigurosas. Empero, tal preocupación «científica» ha terminado en una paranoia conceptual, en la cual la cantidad de citas debe ser proporcional a la calidad de una producción.

El estado del arte como ubicación de quién, cómo y dónde se han planteado elementos que contribuyan a la investigación es la carrera numérica por mostrar un soporte y una suficiencia en el tema. Las investigaciones, en algunos casos, son retazos de retazos donde la voz y el trabajo de quien escribe se difumina en cientos de autores, situación que no quiere decir que la revisión y conceptualización no sean el 
eje primario del soporte de lo que se investiga y brinden categorías que permitan claridad en lo que se desarrolla metodológicamente, sino que destacan el valor propio de una experiencia metodológica e investigativa, la cual si bien tiene antecedentes, no se puede volver tan solo un mar de referencias.

Más que un descubrimiento producto de la revisión documental, de la bibliografía y de la lectura en relación con el tema en el caso concreto de la desaparición forzada de personas en Colombia, es relevante hacer énfasis en uno de los elementos señalados en el capítulo dos de este documento, ya que la complejidad de la violencia en dicho país no puede leerse o investigarse desde una sola perspectiva, pues la mayoría de la literatura se concentra en abordajes jurídicos indispensables para proteger los medios y las herramientas de acción de las víctimas, pero deja entrever un gran vacío por parte de otras áreas.

Como se aclaró, no es que no exista producción desde otras disciplinas, pero esta no es tan abundante y prolija como un tema de tal magnitud lo amerita. Las investigaciones desde la visión que ofrece por ejemplo la psicología en temas como el duelo, la melancolía, la elaboración o los efectos del trauma son sumamente interesantes y permiten hilar escenarios fundamentales para este proceso, tal como lo son la justicia, la verdad y la reparación.

La evidencia más crítica que el tema ofrece para el caso colombiano, sí bien se puede analizar de manera concluyente, no es nuevo para las ciencias sociales, pues esta invita a repensar la naturaleza disciplinar con la que se han formado las personas. Muy poco de la literatura encontrada sobre el tema arroja resultados interdisciplinares o transdisciplinares en documentos concretos; la mayoría de acercamientos entre áreas del saber implican trabajos de campo conjuntos y discusiones en foros, congresos y eventos públicos, pero productos concretos, en su mayoría disciplinares, no se construyen o, por lo menos, no circulan con facilidad. Esta situación supone la necesidad de arrojar articulaciones teóricas, metodológicas y empíricas más dialogantes en términos epistemológicos. 
La metodología de esta investigación, como se ha señalado, se planteó inicialmente desde una perspectiva cualitativa. Esta dio especial peso cuando se hizo referencia al ritual y al símbolo que lo define desde el trabajo etnográfico y, dentro de este, desde las entrevistas semiestructuradas, los diarios de campo y los grupos focales. El trazo por la subjetividad y sus implicaciones en el discurso y el comportamiento que da cuenta de mecanismos de trámite o elaboración se desarrolló desde un principio respecto el análisis del discurso a partir de entrevistas de localización del sujeto ante el trauma.

Como toda experiencia investigativa emergieron nuevos interrogantes que giraron lo planeado desde el principio, dado los hallazgos parciales en cada paso del proceso. Esta investigación encontró de forma consistente en el ejercicio metodológico que las narraciones que dan cuenta de un testimonio son relacionales en espacio y tiempo, ya que el sujeto ocupa lugares de victimización distintos, los cuales son producto de esa lamentable condición sui géneris de la guerra en Colombia donde el padecimiento es activo y dinámico, pues se pasa de sufrir por el trauma, a sufrir por el abandono del Estado o por la indolencia de la población receptora. En cualquier caso, experiencias completamente diferentes $\mathrm{y}$, por ende, testimonios articulados en distintas capas constituyeron la base de un relato marcado por lo que se vivió, pero alimentándose continuamente de lo que se sigue viviendo.

El punto inicial de esta situación lo marcó la revisión documental, ya que a pesar de la extensa bibliografía en relación con el tema, el porcentaje mayoritario de trabajos al respecto hablan de procesos que han terminado donde el desafío central gira en la reconstrucción del tejido social y en la discusión entre el perdón, el olvido y los distintos lugares de la responsabilidad política. Sin embargo, para el caso colombiano esto no es posible dada la continuidad de escenarios vulnerables en territorios en disputa; la falta de garantías en la reparación por parte del Estado y las difíciles condiciones de las poblaciones reasentadas en términos sociales, económicos y culturales.

Así, el sujeto enfrenta desde su condición de víctima identificaciones (Hall, 2003) en el campo social que habita, pero como lo señala el mismo autor, dichas identificaciones, a diferencia de las identidades, 
son parciales, dinámicas y no son cerradas, lo cual, para efectos de un trauma en experiencias como la desaparición forzada, es fundamental para poder pensar en la elaboración.

La noción de víctima en plural implica abrir la denominación en términos políticos, ya que se hace remisión a una persona bajo esa dimensión y se omite la particularidad de las formas de victimizar en un mismo relato de vida. La pretendida objetividad del método debe entender la naturaleza comprensiva de los fenómenos sociales, aclarar el contexto situacional de aquello que se indaga y, en consecuencia, entender que es tan solo una pequeña ruta de una arqueología subjetiva, la cual no se puede generalizar en pos de una investigación, puesto que, es precisamente esta ampliación en la mirada lo que puede posibilitar una alternativa menos asistencial de la reparación o elaboración de una persona afectada por este drama.

Es importante señalar que las negociaciones entre el Gobierno nacional y las FARC-EP abrieron una puerta importante para la voz de las víctimas del conflicto armado donde, indiscutiblemente, no se dará el fin último de la violencia, pero sí se atenuarán las heridas de la guerra en el país. En ese sentido, esta apuesta por la paz obliga a aquellos que trabajan este tipo de fenómenos, en el contexto nacional, a contribuir en la comprensión de lo sucedido en procura de formular alternativas de perdón, reparación y reintegración realmente integrales donde la clasificación amplia de victima permite entender las disposiciones subjetivas y las tomas de posiciones (Bourdieu, 1997) cambiantes de los actores, y desacartonar la idea tradicional de víctima-victimario como una dicotomía cerrada y horizontal donde las apuestas metodológicas cuando se abordan este tipo de problemáticas, sean contextuales y comprensivas, y, en especial, donde el análisis de la información no exceda o generalice una condición tan frágil como esta.

En la realización de las entrevistas y el posterior análisis de estas voces en un mismo emisor se generaban, en ocasiones, reclamos que tenían asidero en múltiples responsables; a pesar de que el discurso se dirigía en su mayoría a la queja hacia el Estado, continuamente se atravesaban otros participes o cómplices en el relato. Allí, fue importante 
pensar que el orden del discurso era situacional y, por ende, el contexto cambiaba para entender un proceso de intervención, reconciliación y reparación con las víctimas donde es indispensable asumir el lugar de todos los actores involucrados por acción u omisión.

Como otro aporte a la discusión metodológica producto del desarrollo investigativo se puede plantear la importancia de repensar las clasificaciones genéricas de afectados o víctimas directas, ya que el mensaje de la desaparición forzada, al ser dirigido a una población en general y en procura de un control biopolítico, va más allá del desaparecido directamente y sus familiares, pues es un mensaje para una comunidad que ve bajo la sombra del ausente un ejercicio de sometimiento de las consecuencias de seguir sus pasos.

Las reacciones al ser múltiples van desde familiares que buscan y huyen, vecinos que se esconden o se solidarizan, habitantes de la población que modifican sus rutinas y respetan esta nueva pedagogía de la barbarie, y diferentes expresiones de toda una población que hace parte de la noción de víctima afectada por la desaparición forzada y donde el trauma, si bien tiene implicaciones más dolorosas en unos casos que en otros, el efecto del miedo y la angustia en la cotidianidad no puede entrar en comparaciones, ya que todos deben reinscribir su cuerpo y su comportamiento a esa nueva norma social.

Al respecto, el trabajo de campo dejó leer tres comportamientos diferenciados en las comunidades afectadas por la desaparición forzada; el primero, el de las víctimas que luchan por encontrar a sus desaparecidos y reclaman una reivindicación política de lo sucedido por medio de diferentes formas de reparación y justicia; el segundo, el de las víctimas que bajo el miedo y el oportunismo aparecen solo en ocasiones donde será pública la denuncia y se dará algún tipo de compensación; y el tercero, el de las víctimas que al ser pobladores de la comunidad tratan de tomar distancia con lo sucedido, omiten su lugar de origen, desconocen lo acontecido o minimiza la situación en su mayoría como recurso de protección ante la repetición o la estigmatización de la zona. 
En los tres casos, las víctimas hacen parte de un proceso que las ha marcado de distintas formas, pero donde todas padecieron y/o padecen las consecuencias del conflicto armado en el país.

En ese sentido, enfrentarse a una experiencia metodológica de estas dimensiones implicó entender que lo vivido tiene múltiples crisis, las cuales alimentan el efecto traumático más allá de los victimarios. Las tensiones implicaron distinguir, en los instrumentos de recolección, el orden de cada malestar, pues la ubicación clara de las categorías articuladas con las responsabilidades en cada caso y en las entrevistas semiestructuradas arrojó la necesidad de usar, en dichos instrumentos, una contextualización al distanciar en tres momentos el antes del suceso traumático, el cual fue caracterizado por las dinámicas socioculturales y políticas; y al destacar, en los resultados, las representaciones del día a día y los conflictos previos que allí se tenían, por ejemplo el trato con los hijos, el modelo patriarcal y la dependencia emocional sobre la figura de autoridad.

Durante el proceso de desaparición se distinguió entre la reacción de búsqueda y las decisiones tomadas para proteger la exposición en la que queda el resto de la familia.

Después del proceso vivido se concentró la mirada en la reconstitución de la subjetividad política; suceso mayoritariamente evidente en mujeres. De igual forma, la relación entre memoria y olvido, la cual se dejó leer en aquellos que fueron hijos de desaparecidos, pero que no recuerdan con claridad lo sucedido y que, en algunos casos, desean mantener ese recuerdo de manera inconsistente.

Aunque al reparar en técnicas o instrumentos de la recolección de la información existen cientos de artículos, libros y reseñas; las investigaciones traen consigo la posibilidad de entender nuevos escenarios que delimitan los actores sociales en contextos específicos. Trabajar con víctimas de conflicto armado implicó asumir la estructura de unas preguntas desde una naturaleza transdisciplinar, lo cual posibilitó leer el cruce analítico construido en las respuestas desde una mirada amplia. 
Esta situación requirió preguntas que abordaran la experiencia vivida en primera persona; una suerte de reconstrucción del pasado de manera libre y espontánea, la cual evocó el testimonio de manera sincrónica y lo asoció después a narraciones de sueños que terminaron siendo producto del deseo de lo vivido, contrario a lo contado en el recuerdo inicial. Posterior a ello, se realizaron cruces metodológicos con entrevistas que ubicaran la experiencia en tercera persona, es decir, una narración de los acontecimientos padecidos por los vecinos u otros miembros de la comunidad donde se dejaron ver algunos lugares que, en el relato propio, no se reconocían.

Este ejercicio metodológico implicó una lectura que vincula tanto la descripción antropológica y la función sociológica, como el abordaje subjetivo, al entender que la relacionalidad del sujeto no se puede comprender si no es con el acompañamiento de otras áreas del conocimiento.

En lo teórico se podría plantear que desde las primeras acotaciones con Frazer (1944) hasta las más relevantes en la contemporaneidad como las de Segalen (2005), los rituales y su eficacia simbólica dependen de las relaciones del contexto, las cuales no se desarrollan desde una dimensión genérica o universal, lo cual obliga a entender entonces, de manera general, solo estructuras puntuales como la temporalidad, los símbolos y las intenciones de estos para cualquier caso. Sin embargo, aquello que debe aún problematizarse tiene que ver con los roles y la susceptibilidad de estos ante la consciencia cuando se habla de eficacia, ya que el sujeto portador de sentido ante el ritual puede pasar de ritualizar una acción para continuar con la espera de su ser querido, pero, con el tiempo, asumir una responsabilidad con el trato previo que se mantenía con el desaparecido o con las acciones que pudieron contribuir en el desenlace del episodio.

«Nydia», por mencionar un caso y después de muchas horas de hablar con ella, mencionó la falta de acompañamiento que tuvo con sus hijos. Al expresar el abandono en el que según cuenta los tenía dijo: «... solo tengo esa foto, y así los recuerdo, ellos no cambian ni de ropa porque esa era la única con la que contaban, siempre» (Virginia, 
comunicación personal, julio de 2014). Ella, al final de la entrevista, terminó asumiendo el hecho de que estuvieron buscando trabajo en cualquier sitio y en cualquier oficio, porque muy niños los mandaban a buscar que hacer y eso, según lo dicho, los alejaba de la protección de la casa.

En ese sentido, el ritual como categoría posee una composición más comprensiva y dinámica que estructural y determinista; situación que implica que la idea de función puede ser una perspectiva temporal, la cual no responde a los intereses expresos de los participantes de este y a sus significantes colectivos, sino a la posibilidad subjetiva de tramitar otros elementos de manera pública, los cuales no se dejan leer con claridad ni siquiera para el portador de sentido.

La ritualidad en la guerra va más allá de un ejercicio sacrílego del cuerpo del otro. En este caso, la desaparición implica una profunda performancia simbólica donde, de manera llamativa, la mayoría de los miembros activos en la escena ritual no están allí por voluntad propia, lo que sería atípico en una actividad de esta naturaleza, pues la composición del ritual se configura con los símbolos que se materializan en el acto físico del ausentar alguien, pero su impronta «posliminal» es más fuerte que su fundamento «liminal», y la consecuencia es más protagónica que la causa y la forma de desarrollarla, es decir, el efecto del control sobre la comunidad posterga el cierre del proceso ritual y lo carga de mayor densidad simbólica que el acto mismo del desaparecer; pues el símbolo adquiere una connotación ambivalente entre lo físico que se desea aparezca de nuevo, y la ausencia del otro, como significante latente en lo real-imaginario y lo presente del desaparecido en lo simbólico-imaginario, mantiene persistente la imagen del otro de manera indefinida.

Se problematizaría entonces el desarrollo colectivo del ritual por medio de misas, actividades focales abiertas y entierros simbólicos como parte de la agenda pública de una comunidad para abordar temas como la búsqueda, la reparación y la elaboración, pero donde es importante tener en cuenta, desde el campo de la funcionalidad subjetiva, la imposibilidad de pensar elaboraciones colectivas, ya que los actos 
simbólicos no pueden tramitar efectos traumáticos individuales, pero sí encontrar vías para resignificar, por medio de este, nuevas experiencias sociales y elementos que ayuden a emerger preguntas desde un principio de realidad-solidaridad, el cual supere la limitada concepción dual entre ser víctima y victimario $y$, por el contrario, ayude a dimensionar las redes sociales que se pueden ver involucradas más allá de los actores visibles. Por ejemplo, la identificación con otros implica una afirmación del significante colectivo en cuanto a la idea de justicia ante el dolor individual. De igual forma, la posibilidad de nuevas dinámicas sociales permite una reconstrucción del tejido social con distintas actividades ajenas al aislamiento.

Finalmente, el ritual como acto indispensable, pero transitorio en ciertos contextos, necesita nuevos significantes individuales más allá de los símbolos colectivos. El encuentro entre víctimas, por medio de asociaciones o actividades de intervención, arrojó en el análisis producto de la investigación entender como afloran nuevos componentes intencionales en la utilidad del rito, hasta el punto que se mitiga un poco el dolor de la ausencia con la búsqueda política de justicia y no repetición.

La subjetividad implica, en el caso del trabajo realizado, entender que se reconocen a sí mismos como personas más fuertes de lo que eran antes de que pasaran los hechos no solo por la manera de enfrentarlo, sino por entender que ese dolor les ofreció una nueva subjetividad política, la cual no sabían que tenían y que, en cualquier caso, podían ejercer. No obstante, se marca el hecho de que infortunadamente la tragedia les hizo entender esta situación cuando ellos mismos podían hacerlo sin necesidad de tanto martirio. No es fortuito que gran parte de la composición de género en las asociaciones de víctimas sea de mujeres y en marcos sociales e históricos muy patriarcales; este criterio de género coincide no solo en el caso colombiano, sino en bastantes experiencias en América Latina.

Aunque se desarrolló anteriormente el componente histórico en relación con los antecedentes contextuales de la desaparición forzada en Colombia, vale la pena puntualizar en la necesidad de no omitir el hecho de comprender los marcos sociales trabajados desde Halbwachs, 
en relación con el fenómeno, pues tal como lo plantea Rojas (2009), respecto a la desaparición forzada, esta constituye finalmente un «... trauma humano de origen exclusivamente humano» (p. 19), en el cual, para desbordar los juicios morales del trato cruel más allá de la guerra como sucede con esta práctica, existió un punto de partida que poco a poco sedimentó la tolerancia social para este crimen.

La responsabilidad colectiva no basta ubicarla entonces en el contexto contemporáneo, ya que esta tiene una tradición cultural en los albores del desarrollo de las ciudades. Los vertiginosos cambios que suscita el progreso arrebataron la condición subjetiva para muchos hombres y mujeres en el nombre de la incertidumbre de sociedades crecientes donde irse a buscar fortuna implicaba la posibilidad de no regresar jamás, pues naturalmente no existían registros y, mucho menos, denuncias que permitieran entender la magnitud del fenómeno, pero sí se construyó una coraza inicial, la cual naturalizó la ausencia de los otros en un marco ininteligible socialmente.

Aunque Halbwachs (2004) contribuye en la comprensión del papel de estos marcos sociales, son las categorías de Assmann (2010) sobre «memoria comunicativa» y «memoria cultural» las que permiten una esquematización de la investigación en relación con su componente histórico. La primera como lo planteo Seydel (2014) al estudiar el concepto de Assmann:

La memoria comunicativa se articula en el discurso oral, se refiere al pasado reciente y se construye dentro de los marcos sociales existentes en un momento dado. Se refiere a la experiencia individual en el contexto de un suceso histórico significativo como, por ejemplo, la Revolución mexicana y el movimiento estudiantil del 68; es decir, atañe al hecho de que el individuo comparta con el colectivo (colegas, amigos, familiares, etc. $[s i c]$ ) en cuanto que coetáneo y testigo ocular sus recuerdos de ciertos acontecimientos, así como lo que escuchó acerca de éstos [sic]. Estos sucesos forman por tanto parte de su biografía (pp. 199-200). 
Y la segunda entendida como «... la memoria cultural $[\ldots]$ exteriorizada y objetivada; se almacena en formas simbólicas estables, artefactos y soportes de diversa índole» (Seydel, 2010, p. 203), se inscribe de manera formal y, en general, de manera oficial mientras la primera hace parte de la experiencia cotidiana, en especial oral.

Aunque ambas están relacionadas entre sí, como lo aclara Assmann (2010), es la «memoria comunicativa» la que deja el insumo inicial desde la socialización vivida y compartida del marco social de la desaparición, pues un entrevistado dijo: «... en esa época voltiábamos mucho de aquí para allá, pero yo siempre lo primero que hacía era preguntar por si alguien conocía un - Erazo - como el apellido no es común era la forma de saber si podía encontrar a mi hermana» (Virginia, comunicación personal, julio de 2014). Esta definición de Antonio en una entrevista realizada en relación con su hermana desaparecida coincide con la cotidianidad de personas que simplemente se iban y nunca regresaban, lo cual creaba una «memoria comunicativa» que insertaba una práctica histórica hasta ahora no muy revisada socialmente. Esta situación se refiere a aquellos que no están ni muertos, ni vivos, pero tampoco están propiamente desaparecidos; son ausentes de sus núcleos familiares y sociales en el margen de movilidad-ausencia que fue común para una época, en especial desde finales del siglo XIX.

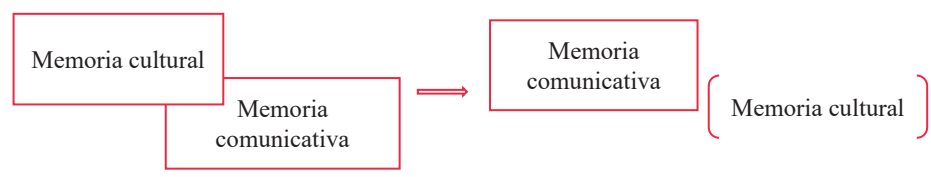

\section{Elaboración propia}

La perspectiva desde el marco social implica un proceso inicial donde la «memoria cultural» modela las prácticas que se presentan en las «memorias comunicativas»; sin embargo, en el trabajo realizado se presenta un giro histórico al momento de hallar que estas segundas, al no tener una pauta desde las primeras, son las que terminan moldeándolas en relación con el papel oficializado de la impunidad, la falta de garantías para todos los ciudadanos y la aceptación legal-social de personas que simplemente están ausentes, no vivos, no muertos o no desaparecidos. 
Cuando se comprende el papel del ritual y su función con la muerte, tal como se hace en el texto, se logra entender cómo este acontecimiento, en general doloroso, es un tránsito fundamental en la construcción de la identidad de un colectivo, pues se afirma o se niega el control político sobre el cuerpo del otro y sobre las mismas personas cuando se puede decidir cómo dejar ir un ser querido.

El ritual de muerte, sea luctuoso o festivo y por diverso que se presente en una cultura, es un mecanismo común a todas las sociedades, ya que no se trata solo de morir, sino de saberlo hacer; es un derecho social que cohesiona a los grupos donde muchos, al no tener control sobre la vida, consideran innegociable tener por lo menos el control sobre la muerte. Así, el cuerpo del difunto no pertenece a ningún bando y su identificación cambia cuando deja de vivir la familia o la comunidad hacen suyo ese muerto.

La desaparición forzada siega ese derecho, el reconocimiento de la identidad social de un desaparecido queda suspendido y, de esta forma, el ritual también muta ante esas nuevas demandas del colectivo o del individuo, las cuales consisten en el derecho a existir vivo o muerto, pero tener un ser en el mundo. En ese sentido, los procesos rituales de muerte no son anómalos para las dinámicas sociales y las elaboraciones, son frecuentes si se cumple con el performance de la muerte que cada cultura decide establecer. Por el contrario, en la desaparición forzada se expresa un imperativo de negación y control sobre el cuerpo del otro y la consciencia queda horadada a diferencia de la muerte cuando pasa por un ritual, pues el sujeto generalmente no queda perforado en su interior, sino maltratado por el dolor de la perdida.

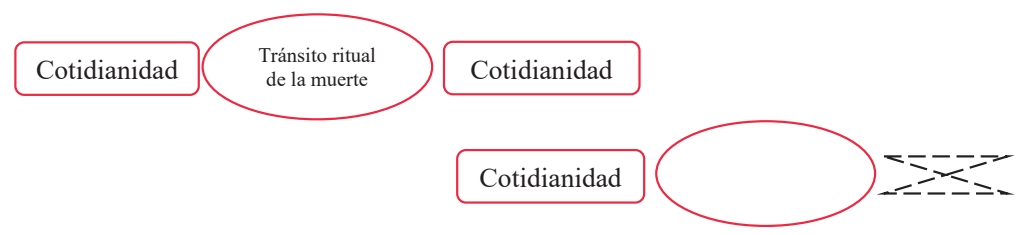

Elaboración propia 
La cotidianidad se reinscribe bajo el poder que ejerce aquel que desaparece, aunque el sujeto intenta proyectar su inserción en la vida social de nuevo. El campo queda agujereado completamente y el objetivo de control del victimario se cumple.

Dicho control «biopolítico» ejercido en estas comunidades irrumpe con el hecho traumático y se proyecta con el sometimiento de la población; ejercicio que según Arendt (2007) determina las diferencias entre violencia y poder, pues dice: «... la forma extrema del poder es Todos [sic] contra Uno [sic]; y la forma extrema de la violencia es Uno [sic] contra Todos [sic]» (p. 39). Allí, el episodio en el cual se da la desaparición forzada constituiría el acto violento, el cual requiere orquestar varios sujetos contra toda una población - no solo los familiares de la víctima directa- El poder se materializa en la zozobra posterior al hecho, la cual ejerce su función en la legitimidad que, para todos, representa un victimario que somete por igual a todos los miembros de la comunidad.

La articulación de los viejos rituales, en especial católicos con prácticas rituales más recientes, no permite una plena adaptación de la aceptación de la muerte, más bien se cosifican prácticas nuevas, como se menciona en el texto, pero se deja en el lugar del dolor melancólico el deseo de despedir al desaparecido, pues no es fortuito que una de las expresiones más frecuentes en muchas de las entrevistas tenían que ver con «... algo queda pendiente» (Germán, comunicación personal, enero de 2015), «... yo descanso cuando lo entierre» (Virginia, comunicación personal, julio de 2014), «... solo espero hasta que regrese así sea en un cajón» (Irene, comunicación personal, marzo de 2013). Estas respuestas hablan de la atadura que se conserva con el ausente y donde el ritual emergente se torna insuficiente dada la intensidad del vínculo. Siguiendo a Díaz (2008), en relación con el duelo,

El tiempo de desaparición le va señalando al sujeto como definitiva la pérdida del objeto que garantizaba su protección y su satisfacción, y el dolor se afianza como única forma de resguardar el vínculo con un ser que ya no está más en la realidad material $[s i c]$ pero que se sostiene todavía en la vida psíquica (p. 16). 
Precisamente, el recurso simbólico que ofrece el ritual no implica el reconocimiento del fallecido, sino la afirmación del deseo por mantener viva su imagen por medio de la angustia persistente. Así, la cotidianidad se torna repetitiva; y se da o se ritualiza en periodos de tiempo el contacto con el otro, ello a través de oraciones diarias, misas cada tanto tiempo, altares que cuentan circunstancias específicas o, simplemente, anécdotas cotidianas donde se dispone de un andamiaje de símbolosobjetos como fotos, estatuillas, imágenes o prendas del desaparecido; y se presenta una temporalidad sincrónica de cada acto como levantarse, orar, mirar la foto, bendecir la vela, entre otros.

De las múltiples prácticas ritualizadas existe una que, a diferencia de las demás, se presenta como sintomática en relación con la desaparición y es, precisamente, la que da cuenta de la vida y la muerte. Esta se refiere a ofrecer una misa, aunque Díaz (2008), de acuerdo a las acciones simbólicas, plantea lo siguiente:

Creemos que frente a la desaparición forzada de personas, las familias pueden apelar a este recurso buscando en su realización la eficacia simbólica que facilita el desenvolvimiento y el desenlace del conflicto psíquico que la pérdida trae consigo. Encontramos así que cada pequeño grupo puede recurrir a algunos rituales propios como los funerales simbólicos y las diversas ceremonias de despedidas, [sic] que ante la ausencia del cadáver acuden a fotografías o a diferentes objetos que representan al ser desaparecido (p. 12).

La efectividad simbólica con acciones colectivas — sugerida por la autora-y, de manera particular, los actos como las eucaristías no son compatibles con la elaboración en lo investigado, ya que, por el contrario, el sujeto queda en estado de ambivalencia entre el deseo de la petición divina para la aparición y el proceso ritual obligatorio por si no vuelve. Las misas públicas y los entierros simbólicos, como el mencionado en Trujillo, operan más como recurso político que como recurso simbólico para el duelo del sujeto. 


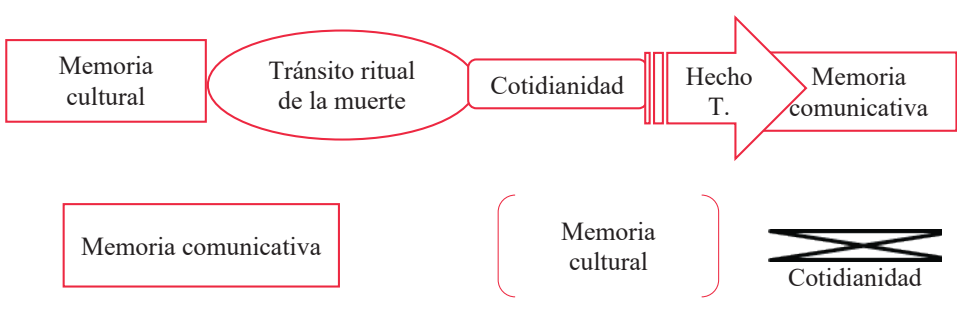

Elaboración propia

Por último, aunque el ritual en sí mismo no representa una vía clara para la elaboración, sí permite dos posibilidades indispensables en estos procesos; por un lado, una efectividad desde el empoderamiento del sujeto de deseo hacia nuevos objetos de la mano de un desplazamiento parcial de la libido dispuesta para la melancolía y, ahora, en función de la búsqueda de justicia, a saber, no una sustitución de aquello insustituible, pero sí una nueva disposición psíquica ante el dolor; por otro lado, una nueva subjetividad social y política producto de nuevas prácticas identificatorias con otras víctimas, lo que permite no solo reconstruir un tejido social al margen de la incapacidad de intervención del Estado, sino una experiencia ciudadana distinta con un actor que asume un papel más vital en la vida pública, y reclama justicia y reparación de sus derechos básicos maltratados de tantas formas.

Aquí se encuentran los puentes que articulan ambos procesos, tanto en lo subjetivo como en lo colectivo, y las necesidades de hacer del recurso simbólico del ritual una experiencia política que desde la implementación de viejas prácticas, la adaptación de nuevas y la creación de otras se puedan pensar procesos que vayan más allá de una intervención asistencial.

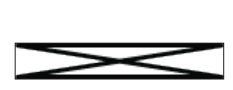

Cotidianidad

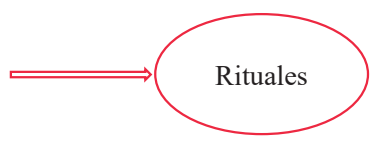

Elaboración propia
Cotidianidades 
La cotidianidad atravesada y agujereada por un trauma debe retomar aquello que le daba significado subjetivo y cohesión colectiva a un sujeto. Todo ello por medio de los significantes del entorno que, antes de la irrupción perpetrada, le brindaban un sentido sea desde lo espiritual, lo familiar, lo político, lo cultural, entre otros aspectos.

Las dinámicas rituales son aquellas que, precisamente, otorgan una dimensión estructurada y estructurante a las poblaciones; un sentido, un valor y unos acumulados, los cuales se resignifican desde nuevas narraciones que interactúan con la realidad y con el deseo de expresión de un actor social, es decir, son juegos, representaciones, performancias, repeticiones $\mathrm{y}$, ante todo, recursos que dislocan el comportamiento normal e inscriben relatos más legítimos y menos condicionados al deber ser del sujeto, pues, precisamente en estas prácticas, se permiten libertades y goces anómicos que, de otra manera, no se pueden obtener.

Es por ello que el valor del ritual permite entender, de forma más genuina, un individuo y su entorno y, de igual forma, posibilita crear otras cotidianidades, ampliar la mirada o tramitar inhibiciones, represiones o angustias concentradas por medio del mismo. 


\title{
Post scriptum. Diarios de campo en tensión
}

\begin{abstract}
Al margen, en los márgenes y desde los márgenes terminó esta investigación después de tantos años, entrevistas, lecturas y cuidados para respetar la lógica académica formal; me doy una licencia en este cierre. Me aparto del rigor conceptual que parece como la forma más convencional para validar un texto académico, soportar lo que se plantea teórica y metodológicamente en un autor o en una investigación para darle pertinencia a nuestras propias palabras, pues por momentos terminamos invadidos de la paranoia de no ser lo suficientemente referencialistas.
\end{abstract}

En este pos escrito quiero omitir toda clase de acompañamiento; quiero tan solo narrar algunas ideas de mi experiencia etnográfica con lo investigado, y recomponer mi voz y la libertad de usarla en un tema tan doloroso como lo fue sacar adelante este proyecto.

Recuerdo que cuando acababa de leer un texto, un testimonio o un dato me preguntaba si sería capaz de soportar el dolor ajeno, pues era muy intenso el testimonio de aquellos que pasaron o pasan por este flagelo. Me inquietaba saber si podría contener la profunda tristeza del otro, dado que esta no era mediada por un papel, sino que estaba de frente, ante mí.

Las primeras entrevistas no fueron las más difíciles, como suele pasar en estos temas, por el contrario, fueron más sencillas. En la medida que me acercaba con mucha cautela a cada pregunta y cada interpelación, me blindé un poco de la información de aquellas víctimas, las cuales el dolor las había hecho duras en su testimonio y relataban como al declamar un poema; sin pausas y con los énfasis que, al pasar de los años, parece habían aprendido. Estos relatos eran significativos para los que nos interesa escucharlos, ni siquiera era necesario volver sobre ciertos episodios angustiantes, ellos mismos los retomaban sin mediar palabra. 
Tiempo después entendí que esas primeras entrevistas hablaban de personas para las cuales el relato se sostiene en una balanza, pues se debe mantener en equilibrio para sobrellevar la pena; lo dicho y lo omitido de forma sincrónica, y saber mostrar y saber esconder una suerte de melodía de la tragedia que encuentra su armonía en la tranquilidad del compás y en la intensidad repentina de este (Adiós nonino).

Seguí esas voces por distintos escenarios, a saber, en sus casas, en parques y en escuelas; sin embargo, era indiferente el sitio, cada nueva entrevista se hacía más difícil, en muchos casos con las mismas personas, así supe que era yo el que iba cambiando, es cierto, la mirada naturalmente era más cualificada, pero la impronta del dolor de ellos también se hacía más honda, entendí que los comprendía un poco más.

El pasado era espinoso y el recuerdo era dramático a pesar de haber vuelto sobre la escena de lo vivido tantas veces tanto en lo público, en lo privado y en silencio. Haciendo revisión de cada momento, hablaban de ello como una bitácora con cada instante bien definido y diferenciado; en la medida en que se acercaban al momento de la partida de su ser querido para nunca regresar, sus voces se conservaban en línea recta, pero mi escucha se quebraba como quien quiere llegar al centro de una historia. No obstante, al tiempo daba vergüenza de sentir que se estaba arrastrando al otro de nuevo a un camino de profunda tristeza y del cual, para el retorno a la cotidianidad, no podía ofrecer mayor cosa; era inverosímil escuchar que alguien vivió tanto dolor y que, ahora, lo podía apalabrar.

Un día, al terminar una visita de campo, una señora se me acerca y me agradece por haber ido, me dice que no imagino lo sanador que es para ellos hablar del tema y que es recordarse a sí mismos que no debió haber pasado, pero que sus desaparecidos están vivos ahí, precisamente por poder mantenerlos en cada testimonio que dan, pues callar es dejarlos ir en silencio y condenarlos más de lo que ya están. Ese día pude comprender lo terapéutico de la palabra; comprendí que en ese intercambio existían papeles que nunca habían tenido y que, debido a la tragedia, ahora asumen con vitalidad; que estaba ahí para legitimarlos (cambalache) y para darles un estatus como sujetos políticos, como agentes de dignidad en busca de justicia. 
Ese cambio de víctima a sujeto político empoderado de una acción reivindicadora era una enseñanza que me ayudaba a reconfigurar un cambio en la noción de victimización inerte hacia la militancia ciudadana, la cual encontró en la tragedia posibilidades de redescubrirse.

Así, supe que de poder volver al pasado harían lo imposible porque su ser querido no se marchara para siempre, pero que no se permitirían tampoco regresar a una sociedad que los había mancillado desde muchos años antes de la tragedia. Su reclamo surge en ese drama, pero no debió ser así, su identidad, su presencia pública, sus derechos, su voz y su lugar, los cuales eran invisibles e inexistentes, ahora son asumidos, apropiados y habitados.

Tristemente, antes de la incursión del verdugo estaban desaparecidos los habitantes imaginarios de una sociedad que ve lo rural con marginalidad. La indolencia social alimentó la fragilidad de este poblador, el cual fue y es instrumentalizado por distintos actores armados bajo ciertas conveniencias, entre ellos - en el peor de los escenarios- el Estado.

La verdad es como una cortina que deja pasar aquello que deseamos con base en la intensidad de luz que se permite entrar. ¿Qué iluminamos finalmente?, una trama de sentido, la cual pretende obturar por medio de un análisis riguroso aquello que ha sucedido. ¿Cómo?, y ante todo ¿por qué?, ¿qué se esconde en actos de tal sevicia? El trabajo tejió esa urdimbre compleja de forma focal y procuró ir hasta los bordes de la reparación e indicar algunas herramientas para ello; sin embargo, al analizar toda la información, y al interpretar los datos y codificarlos con categorías, me doy cuenta de que esta investigación no me habló solo sobre su relato y sobre su tragedia, me habló también sobre mi rol y mi papel como académico, como profesional, como padre y, ante todo, como sujeto y/o sujeto político; cientos de preguntas afloraron a partir de ello.

Las preguntas se tornaron en ideas inciertas de lo que hacía, por tanto, traté de organizar los recuerdos pasajeros de mi experiencia de campo en las zonas afectadas y en los barrios de reasentados. Empecé: recorría las calles con grabadora en mano; entraba en las salas y escuchaba de 
pie ante la tumba «simbólica» de un hijo, de un hermano o de un amigo; organizaba las preguntas de forma clara, pero no intrusiva; me detenía en las pausas para dejar aflorar las emociones sin apresurar las palabras que las describían; entendía cuándo, con cierta mirada de forma sutil, me sacaban de la entrada de sus hogares, pues era una presencia extraña e incómoda que no siempre era bienvenida por todos los miembros; escribí sus silencios sin inducir mis ideas.

Después de un tiempo, al leer cada entrevista y al escucharlas, también me escuche y me leí a mí mismo; caí en cuenta de que, posterior al trabajo con esos datos, estaba de repente parado ante mi propio discurso en un principio agobiado por la impotencia del efecto real de lo que hacía, el alcance y el no tener un arribo a la vista. Posteriormente, atiborrado de trabajo y envuelto en la escritura, transité entre el ir y volver con los testimonios, el revisar la literatura que aparecía respecto al tema, y el hacer socializaciones parciales en eventos públicos respecto a los hallazgos y datos nuevos.

Así transcurrieron varios meses, identifique finalmente que el ritual y la elaboración pueden tener trámites colectivos e individuales al depender del contexto; que la verdad tiene un rol primario en la reparación; que la justicia inicia por esta para que sea legítima; y que es fundamental trabajar, proponer, investigar sobre ello de la mano de todo lo que se ha dicho al respecto. Inclusive, lo que acabo de enunciar no es del todo nuevo, pero sí aporta investigativamente para trazar el mapa de la violencia en el país, pues la etnografía y el psicoanálisis pueden ser puentes muy útiles para cartografiarnos, para entendernos, y para reconocernos en la igualdad y en la diferencia.

Muchos rostros se me vienen a la cabeza al final de esta escritura, se advierte una clausura y me siento profundamente agradecido por cada una de esas personas que hicieron posible esta investigación; sus palabras laceran la idea de un mundo justo, pero no dejan de abrazar la esperanza de que todo algún día cambie y que estas escenas por fin acaben para un país cansado de contarse historias de terror, las cuales no son imaginadas por nadie, sino padecidas por muchos. 
Por último, el punto final para esta investigación se hizo suspensivo, prolongado y ahí voy hace un tiempo. Creo que este escrito es una manera de reconocer que cierre no existirá, que, tal como sucede con el ritual, el final abre la entrada para un nuevo encuentro y, quizás, necesitaba decírmelo de manera explícita (Volver). 


\section{Referencias}

AdORno, T. (1998). Educación para la emancipación, conferencias y conversaciones con Hellmut Becker (1959-1969). Ediciones Morata.

Agamben, G. (2003). Homo Sacer. El poder soberano y la vida desnuda. Editorial Pre-Textos.

Agudelo Patiño, L. y Sanchez Villada, P. (2013). Exploración del proceso de duelo en familiares de personas víctimas de la desaparición forzada en el Valle del Cauca. [Trabajo de grado para optar al título de psicóloga. Universidad del Valle, sede Buga, Valle del Cauca]. Archivo digital.

Amnistía Internacional. (1987). Ley de punto final: Argentina. Londres: Editorial Amnistía Internacional.

. (2008). ¡Déjennos en paz! La población civil, víctima del conflicto armado interno en Colombia. Editorial Amnistía Internacional.

Apud, I. (2011). Magia, ciencia y religión en antropología social. De Tylor a Levi-Strauss. Nómadas. Critical Journal of Social and Juridical Sciences, 30(2), 1-18. https://www.redalyc.org/ articulo.oa?id=18120143021.

Arboleda Gómez, R. (2008). La cultura corporal en los negros macondianos: reconfiguración de identidad y retórica de ciudadanía. Boletín de Antropología Universidad de Antioquia, 22(39), 52-81. https://www.redalyc.org/pdf/557/55711908003. pdf.

. (2009). El cuerpo: huellas del desplazamiento. El caso de Macondo. Hombre Nuevo Editores. 
Arendt, H. (2007). Responsabilidad y juicio. Ediciones Paidós.

Assmann, J. (2010). Communicative and Cultural Memory. In A. Erll and A. Nünning (eds.), A Companion to Cultural Memory Studies (pp. 109-118). Walter de Gruyter.

Barrera SÁnchez, O. (2011). El cuerpo en Marx, Bourdieu y Foucault. Iberofórum. Revista de Ciencias Sociales de la Universidad Iberoamericana, 6(11), 121-137. https://www.redalyc.org/ pdf/2110/211019068007.pdf.

BARTHES, R. (2004). Crítica y verdad. Siglo xxI Editores.

Berger, P. (1967). Introducción a la sociología. Editorial Limusa Wiley.

BeVERLey,J.(1987).Anatomía del testimonio.Revistade Crítica Literaria Latinoamericana, Año 13(25), 7-16. https://people.unica.it/ riccardobadini/files/2020/03/Anatom $\% \mathrm{C} 3 \% 83 \% \mathrm{C} 2 \% \mathrm{ADa}-\mathrm{del}-$ testimonio.pdf.

. (2004). Testimonio: on the Politics of Truth. University of Minnesota Press.

BlaIR, E. (2010). La política punitiva del cuerpo: "economía del castigo" o mecánica del sufrimiento en Colombia. Estudios Políticos, (36), 39-66. http://www.scielo.org.co/pdf/espo/n36/ n36a3.pdf.

Bourdieu, P. (1997). Capital cultural, escuela y espacio social. Siglo XXI Editores.

Caracol Radio. (2006, 19 de enero). Mauricio Santamaría, encargado de planeación nacional, habla de las cifras de reducción de la pobreza. Caracol Radio. https://caracol.com.co/ radio/2006/01/19/audios/1137669300 239822.html. 
Cardona Moncada, J. y Vasco Badillo, L. J. (2013). Trabajo de duelo en sobrevivientes de la masacre de la vereda Alaska, zona rural de Guadalajara de Buga. [Trabajo de grado para optar al título de psicóloga. Universidad del Valle, sede Buga, Valle del Cauca]. Biblioteca digital. https://bibliotecadigital. univalle.edu.co/bitstream/handle/10893/9297/CB-0513935. pdf? sequence $=1 \&$ isAllowed $=\mathrm{y}$.

Castillejo CuÉllar, A. (2009). Los archivos del dolor: ensayos sobre la violencia y el recuerdo en la Sudáfrica contemporánea. Universidad de los Andes.

Centro Nacional de Memoria Histórica [CNMH]. (2013). Huellas y rostros de la desaparición forzada (1970-2010). Tomo II. Imprenta Nacional. http://www.centrodememoriahistorica.gov. co/descargas/informes2014/desaparicion-forzada/Tomo-II.pdf.

COMISIÓN DE LA VeRDAD. (2021). Balance estadístico afectaciones a los derechos humanos en AMCO Risaralda. [Informe físico entregado al Puesto de Mando Unificado de Derechos Humanos de Risaralda].

Comisión Interamericana de Derechos Humanos [OEA]. (1974). Informe anual de la comisión interamericana de derechos humanos. https://www.cidh.oas.org/annualrep/74sp/indice.htm.

Gobierno de Colombia. (1986). Constitución política de Colombia. https www.funcionpublica.gov.co/eva/gestornormativo/norma. php?i=7153.

DECLARACIÓN DE LOS DERECHOS HUMANOS Y DEL CIUDADANO DE 1789. (s. f.) https://www.conseil-constitutionnel.fr/sites/default/files/ as/root/bank_mm/espagnol/es_ddhc.pdf.

Díaz Facio Lince, V. E. (2008). Del dolor al duelo. Límites al anhelo frente a la desaparición forzada. Affectio Societatis, (9), 1-20. https://revistas.udea.edu.co/index.php/affectiosocietatis/article/ view/5323/6578. 
Díaz Mansilla, L. F. (2011). Desaparición forzada en Colombia. Medios de comunicación y memoria [Tesis de Maestría en Derechos Humanos y Democracia, Facultad Latinoamericana de Ciencias Sociales (FLACSO)]. https://repositorio.flacsoandes. edu.ec/xmlui/bitstream/handle/10469/3343/TFLACSO-032011LFDM.pdf?sequence $=1$ \&isAllowed $=\mathrm{y}$.

Douglas, M. (1973). Pureza y peligro: un análisis de los conceptos de contaminación y tabú. Siglo XXI Editores.

DurKheIm, E. (1912). Las formas elementales de la vida religiosa. Alianza Editorial.

EstradA, L. (2016). La escritura del horror en los cuerpos: violencia ontológica y simbolismo de crueldad. Estudios Politicos, (37), 57-80. https://reader.elsevier.com/reader/sd/pii/S018516161 6000044? token $=5$ FBC230B0A1E321622EEEB9D83AB58B 341C9769612FC571AEDDF2ED68156296EC79BC4AEC4 546C657597D678DAC9D9EE\&originRegion=us-east-1\&originCreation $=20210831044043$.

Estrada, I. (2013). El documental cinematográfico y televisivo contemporáneo. Memoria, sujeto y formación de la identidad democrática española. Boydell y Cervecero.

Eyssautier De la Mora, M. (2006). Metodología de la investigación: desarrollo de la inteligencia. Thomson Editores.

Forges, J. F. (2006). Educar contar Auschwitz. Historia y memoria. Anthropos Editorial.

Foucault, M. (2004). Vigilar y castigar. Siglo XXI Editores. . (2008). Los anormales. Fondo de Cultura Económica.

- (2010). Nacimiento de la biopolítica. Fondo de Cultura Económica. 
FRAZER, J. (1944). La rama dorada: magia y religión. Fondo de Cultura Económica.

FreUd, S. (2006). Lecciones introductorias al psicoanálisis. Lección xxv, la angustia. En S. Freud, Obras completas. Tomo 6 (pp.188-212). Editorial Biblioteca Nueva.

FreUd, S. (1991). Obras completas. Tomo 6. Editorial Biblioteca Nueva.

Galeano, E. (1967). Guatemala, país ocupado. Editorial Fundamentos.

Gálvez, A. (2008). Apuntes de contexto. [Documento de lectura]. Seminario Investigación. Maestría en Antropologia. Universidad de Antioquia.

García Reinoso, G. R. (1986). Matar la muerte. Revista Psyché, (1), 1-12. https://www.apdh-argentina.org.ar/sites/default/files/u6/ matar_la muerte.pdf.

GARCÍA, F. y GIL, M. (2009). Etnografías de la muerte y las culturas en América Latina. Revista Española de Antropología Americana, 39(1), 244-248.

Giraldo Herrera, J. H. (2012). «Si esto sigue en silencio, estamos sepultando la dignidad humana». Semana. https://www.semana. com/si-esto-sigue-en-el-silencio-estamos-sepultando-tambienla-dignidad-humana-javier-giraldo/263718-3/.

GIRARD, R. (1985). La violencia y lo sagrado (M. VuILlemain, Trad.). Editorial Anagrama.

Gluckman, M.; Douglas, M. y Horton, R. (1976). Ciencia y brujería. Editorial Anagrama.

GonzÁLEZ, N. (1998). Los derechos humanos en la historia. Editions Universitat de Barcelona. 
Gutiérrez Contreras J. C. y Villegas Díaz, M. R. (1998). Derechos humanos y desaparecidos en dictaduras Militares. América Latina Hoy, (20), 19-40.

HalbWaChs, M. (2004). Memoria colectiva y memoria individual. En M. Halbwachs, La memoria colectiva (pp. 25-52). Prensas universitarias.

Hall, S. y Du Gay, P. (Comp.). (2003). Cuestiones de identidad cultural. Amorrortu Editores. https://antroporecursos.files. wordpress.com/2009/03/hall-s-du-gay-p-1996-cuestiones-deidentidad-cultural.pdf.

JASPERS, K. (1998). El problema de la culpa. Sobre la responsabilidad política alemana. Editorial Universitat Autònoma de Barcelona.

JoDELET, D. (1986). La representación social: fenómenos, concepto y teoría. En S. Moscovici, Psicología social. Tomo II (pp. 469-494). Editorial Paidós. https://www.researchgate.net/ profile/Serge-Moscovici-2/publication/31733289 Psicologia social_II_Pensamiento_y_vida_social_psicologia_social_y problemas sociales/links/5d4bce $384585153 \mathrm{e} 5945585 \mathrm{~d} /$ Psicologia-social-II-Pensamiento-y-vida-social-psicologiasocial-y-problemas-sociales.pdf.

Kordon, D. y Edelman, L. (1988). Efectos psicológicos de la represión política. Sudamericana-Planeta.

Lacan, J. (1981) Los escritos técnicos de Freud. Seminario 1. Editorial Paidós.

La Silla Vacía. (2012, 19 de junio). Los hilos invisibles entre la Oficina de Envigado y el entorno de Uribe. La Silla Vacía. https://www. lasillavacia.com/historias/silla-nacional/los-hilos-invisiblesentre-la-oficina-de-envigado-y-el-entorno-de-uribe. 
LEVI, P. (2002). Si esto es un hombre. Editorial Muchnik.

LeVi-Strauss, C. (1984). Pensamiento salvaje. Fondo de Cultura Económica.

LEY 589 DE 2000. (2000, 6 de julio). Congreso de la República. Diario oficial No. 44.073. http://www.secretariasenado.gov.co/senado/ basedoc/ley 0589 2000.html.

López, C. y Sevillano, O. (2008). Balance político de la parapolítica. https://www.ideaspaz.org/tools/download/54297.

Losonczy, A. M. (2011). Violencia social y ritualización de la muerte y del duelo en Colombia. Revista Anthropos, (230), 135-146.

Martínez, B. (2013). La muerte como proceso: una perspectiva antropológica. Ciência \&Saúde Coletiva, 18(9), 2681-2689. $\quad$ https://www.scielo.br/j/csc/a/ NdyJ69TNZNCp4XQbD4GCmxC/?format=pdf\&lang=es.

Martínez, J. M. (2018, del 19 al 23 de noviembre). Memorias de la violencia política, la desaparición forzada y el ritual mediador [ponencia]. Octava Conferencia Latinoamericana y Caribeña de Ciencias Sociales. Buenos Aires, Argentina. https:// www.clacso.org.ar/conferencia2018/presentacion_ponencia. php?ponencia=20185215539-1459-pi.

Mauss, M. (1970). Obras. Editorial Seix Barral.

. (1971). Sociología y antropología. Tercer Mundo Editores.

Murillo, S. (2008). Colonizar el dolor, la interpelación ideológica del banco mundial en América Latina. El caso argentino desde Blumberg a Cromañón. Consejo Latinoamericano de Ciencias Sociales (CLACSO). http://bibliotecavirtual.clacso.org.ar/ar/ libros/becas/murillo/04Murillo.pdf. 
Nahoum-Grappe, V. (2002). Anthropologie de la violenceextrême: le crime de profanation. Revue Internationale des Sciences Sociales, 4(174), 601-609. https://www.cairn.info/revueinternationale-des-sciences-sociales-2002-4-page-601.htm.

Noticias de Santander (2015, 29 de agosto). 1.453 víctimas de desaparición forzada piden justicia en Santander. Vanguardia Liberal. https://noticias-de-santander.com/1-453-victimas-dedesaparicion-forzada-piden-justicia-en-santander-vanguardialiberal-2/.

NunCa MaIs. (1985). Petrópolis. Arquidiocese de Sâo Paulo.

Palma Florián, C. J. (2016). La desaparición forzada: una verdad caleidoscópica. Desde el Jardín de Freud: revista de psicoanálisis, (16), 187-212. https://dialnet.unirioja.es/servlet/ articulo? codigo $=5644086$.

RAmírez Guerrero, E. S. (2014). El trabajo de duelo frente a personas desaparecidas. Análisis de caso. Daena: International Journal of Good Conscience, 9(1), 115-121. http://spentamexico.org/ v9-n1/A10.9(1)115-121.pdf.

Redacción Negocios. (2009, 21 de agosto). Recursos para seguridad y defensa superarán por primera vez los de educación. El Espectador. https://www.elespectador.com/economia/recursospara-seguridad-y-defensa-superaran-por-primera-vez-los-deeducacion-article-167967/.

Redacción El Tiempo. (1997, 4 de septiembre). Costa Caribe, la región más pobre del país. El Tiempo. https://www.eltiempo. com/archivo/documento/MAM-624921.

Revista Forensis. Datos para LA VIDA. (2015). Capítulo "Comportamiento de muertes y lesiones por accidente de transporte. Colombia, 2015". Medicina Legal y Ciencias Forenses, (1), 422-478. 
Semana (2010, 16 de junio). Comunidad de Paz de San José de Apartadó pide justicia. [Video]. Semana. https://www.semana. com/nacion/conflicto-armado/articulo/comunidad-paz-sanjose-apartado-pide-justicia/118115-3/.

UNIDAD PARA LA ATENCIÓN Y REPARACIÓN INTEGRAL DE LAS ViCTIMAS. (s.f.). Víctimas conflicto armado. Registro único de víctimas. https://www.unidadvictimas.gov.co/es/registro-unico-devictimas-ruv/37394.

Verdad Abierta. (2011, 8 de noviembre). Informe Los 'paras' y el narcotráfico en Caquetá, 8 de noviembre de 2011. Verdad abierta. https://verdadabierta.com/los-paras-y-el-narcotraficoen-caqueta/.

ResoluCión 32/118. (1977, 16 de diciembre). Naciones Unidas. Protección derechos humanos en Chile. https://www.un.org/es/ documents/ag/res/32/ares32.htm.

RESOLUCión 32/173. (1977, 19 de diciembre). Naciones Unidas. Recursos de la fundación para el hábitat y los asentamientos humanos https://www.un.org/es/documents/ag/res/32/ares32. htm.

Restrepo, E. (2012). Antropología y estudios culturales. Disputas y confluencias desde la periferia. Siglo XxI Editores.

Ríos Castro, D. (2020). Ritual de exorcismo. Nociones de salud enfermedad y sanación a partir de las misas de liberación del padre "Chucho" en Bogotá, Colombia [Tesis de pregrado, Universidad Externado de Colombia]. Archivo digital. https:// bdigital.uexternado.edu.co/bitstream/handle/001/3101/ DDA-spa-2020Ritual_de_exorcismo_nociones_de salud_enfermedad_y_sanacion_a_partir_de_las_misas; nid $=$ C22C981F3BA30359387FCB2B1EF7A0FC? sequence $=1$. 
RoJas, P. (2009). La interminable ausencia, estudio médico psicológico y político de la desaparición forzada. Editorial LOM.

SÁez Blasco, F. (2000). El proceso ritual de Víctor Turner. Antropología cognitiva y simbólica. UNED Centro Asociado de Melilla.

SÁnchez, G. (2011). La (des)memoria de los victimarios. Silencios y voces de víctimas y victimarios. Revista Anthropos, (230), 7179.

Schindel, E. (2012). La desaparición a diario. Sociedad, prensa y dictadura (1975-1978). Editorial Universitaria de Villa María (EDUVIM).

Schwartz, B. (1992). La reconstrucción de Abraham Lincoln. En D. Middleton y E. Derek Memoria compartida, la naturaleza social de la memoria y el olvido (pp. 97-123). Editorial Paidós.

Segalen, M. (2005). Ritos y rituales contemporáneos (A. MARTORELL LinARES, Trad.). Alianza Editorial.

Seydel, U. (2014). La constitución de la memoria cultural. Acta Poética, 35(2), 187-214. https://reader.elsevier.com/reader/sd/ pii/S0185308214724253?token=27B60DD44D1118C47E3BA FAD3CCA2B497D4362483F4015B19C0D27C5703B12774D D192375AE50BB378FC6822BA862759\&originRegion=useast-1\&originCreation $=20210831054700$.

Sontag, S. (2004). Ante el dolor de los demás. Editorial Santillana.

Souza. B (2004). Reinventar la democracia, reinventar el Estado. (2. ${ }^{\mathrm{a}}$ ed.). Editorial Abya-Yala.

Tirado Mejía, A. (1995). Los partidos políticos en Colombia. Revista de Extensión Cultural, (156). https://repositorio.unal.edu. co/bitstream/handle/unal/56810/alvarotiradomejia.1995. pdf? sequence $=1 \&$ isAllowed $=y$. 
TURner, V. (1997). La selva de los símbolos: aspectos del ritual ndembu. (3. ${ }^{\text {a } E d .) . ~ S i g l o ~ X x I ~ E d i t o r e s . ~}$

. (1988). El proceso ritual. Estructura y antiestructura. Editorial Taurus. https://www.academia.edu/43259367/E1 proceso ritual_Estructura_y_antiestructura_Victor_Turner.

VAn GenneP, A. (1989). Los ritos de paso. Editorial Taurus.

Velasco, H. y DíAz de RadA, Á. (1997). La lógica de la investigación etnográfica: un modelo de trabajo para etnógrafos de la escuela. Editorial Trotta.

Vestri, G. (2015). Colombia: ¿convirtiendo la desaparición forzada y los "falsos positivos" en política de Estado? el actual (y no tan actual) estado de la cuestión. Derechos y Libertades, (32), 275299. https://e-archivo.uc3m.es/bitstream/handle/10016/22463/ DyL-2015-32-vestri.pdf?sequence=1.

Weber, M. (1984). La acción social: ensayos metodológicos. Ediciones Península.

ZoRIo, S. (2011). El dolor por un muerto-vivo. Una lectura freudiana del duelo en los casos de desaparición forzada. Desde el Jardín de Freud. https://revistas.unal.edu.co/index.php/jardin/article/ view/27261/39654.

- (2011). El duelo en los casos de desaparición forzada de las víctimas de violencia política. [Proyecto de Tesis de Maestría. Maestría en Psicoanálisis, subjetividad y cultura]. https://1library.co/document/zp25jkoy-duelo-casosdesaparicion-forzada-victimas-violencia-politica.html. 
Este libro fue terminado por la editorial de la Universidad Tecnologica de Pereira en junio del 2021, bajo el cuidado del autor.

Pereira, Risaralda, Colombia. 
Los involucrados en prácticas relacionadas con la desaparición forzada no se reducen a lecturas binarias concentradas habitualmente en la relación víctimas-victimarios, los actores son diversos y los efectos que tiene tal situación varían dependiendo de la manera como se ubican ante el acontecimiento, el momento en el cual deben enfrentar una relación con lo vivido y las perspectivas que agentes externos construyen sobre territorios afectados por ello.

La condición de afectación es tan amplia como las formas de enfrentarse que encuentran los diferentes miembros de una comunidad ante un ejercicio de violencia tan fuerte y permanente en el tiempo, a diferencia de otras formas de violencia esta además alimenta la condición de angustia, incertidumbre y miedo, a partir de la ausencia de un cuerpo que al no aparecer, no permite cerrar un trauma por medio de los recursos simbólicos que como colectivos nos valemos en este tipo de pérdidas, ésto con la intención de continuar en medio de la tristeza pero tratando de caminar desde lo vivido.

El desaparecer forzosamente implica una herida abierta dirigida a una población, que sobrevive, se adapta y resiste. El tejido roto que implica esta forma de violencia no se puede abordar en un tiempo específico, tiene impactos inconmensurables que se deben entender desde miradas más estructurales; el ritual, es uno de estos recursos que habla de las prácticas cotidianas de la comunidad, así como de los trámites emergentes de estas ante situaciones de violencia como las padecidas, termina siendo entonces éste un dispositivo cultural que atraviesa el contexto cotidiano y las huellas que deja este tipo de experiencias de forma tanto individual como colectiva.

\section{Facultad de Bellas Artes y Humanidades} Colección Trabajos de Investigación 